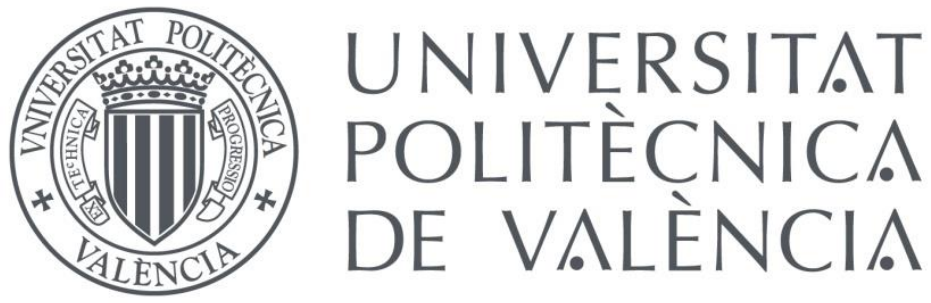

CULTIVOS PARA EL CAMBIO CLIMÁTICO SELECCIÓN Y CARACTERIZACIÓN DE VARIEDADES DE JUDIA (Phaseolus vulgaris L.)

Y Phaseolus Iunatus TOLERANTES A LA SEQUÍA Y SALINIDAD

SUGENITH ARTEAGA CASTILLO

Directores:

Oscar Vicente Meana Monica Tereza Boscaiu Neagu

Valencia, Marzo 2021 
Mis más sinceros agradecimientos a todas aquellas personas que durante este tiempo han caminado conmigo en este pasaje en dónde la Investigación ha hecho parte de todo un proceso de crecimiento profesional.

A Dios, por brindarme esta oportunidad.

A Mis Chavelitas, gracias a ustedes esto es posible. Su sacrificio, acompañamiento y amor han permitido que estas líneas sean escritas hoy.

A Mónica y Oscar, grandes en lo profesional y en lo personal. Gracias a ustedes hoy esto es posible.

A María José Diez y Jaime Prohens, buenos formadores, con sus enseñanzas me motivaron y me llevaron al conocimiento de lo desconocido, infinitas gracias.

A Victoria, Lorena, Primi. Todos ellos con su buen desempeño en los invernaderos hacen parte de que las investigaciones desarrolladas en este proyecto, además con sus ánimos y energía hicieron parte importante en mi tiempo en la Universidad.

A mis padres, con gran esfuerzo han sido motivadores de este gran proyecto.

A Manuel, gracias por apoyarme, animarme, por darme fuerzas en los momentos difíciles y por estar allí cuándo lo necesitaba.

A mis amigos: Manel, Yody, Ros. No ha sido fácil pero gracias a ustedes a sus acompañamientos, a su amor, paciencia y apoyo esto es una realidad hoy en día, manifiesto mi afecto y gratitud. 


\section{Resumen}

La Judía (Phaseolus vulgaris L.) se originó en el continente americano, específicamente en la zona mesoamericana, y su domesticación se produjo de forma independiente en el área mesoamericana y la zona andina, dando lugar a dos acervos genéticos bien diferenciados. También se observó que las poblaciones silvestres andinas se originaron a partir de solo unos pocos miles de individuos de las poblaciones silvestres mesoamericanas, lo que produjo un gran cuello de botella en la formación de la población andina. Durante siglos de cultivo en la Península Ibérica después de su introducción en el siglo XVI, las judías se adaptaron a nuevos entornos, evolucionando numerosas variedades locales.

Se evaluaron cultivares españoles locales de Phaseolus lunatus (frijol lima) y su resistencia a la salinidad, en dónde se expusieron las plantas a varios tratamientos de sal, con el fin de evaluar el efecto de la salinidad en el crecimiento y el rendimiento del cultivo. Se determinaron parámetros de crecimiento y bioquímicos. Y se observó que el estrés salino redujo el peso fresco de los órganos aéreos, lo que permitió clasificar los cuatro genotipos según su tolerancia a la salinidad. La concentración de los pigmentos fotosintéticos no presentó variación, excepto en los carotenoides que se redujeron en el cv menos tolerante a la sal (cultivar) VPH-79. Las concentraciones de $\mathrm{Na}^{+}$y $\mathrm{Cl}^{-}$de las hojas aumentaron con el aumento de la concentración de sal, la concentración de $\mathrm{K}^{+}$no fue significativa en el cultivar más tolerante 'BGV-15410', la relación $\mathrm{K}+/ \mathrm{Na}^{+}$sufre una reducción sólo en los cultivares BGV-12848 y BGV-1588. Además, la prolina aumentó en todos los cultivares, más notablemente en el cv. VPH-79, con las concentraciones absolutas más altas registradas en los cultivares más tolerantes a la sal. Curiosamente, estos cultivares ya tenían una concentración de prolina relativamente más alta en plantas no estresadas. Estos hallazgos indican que $P$. Iunatus es moderadamente tolerante a la sal y que sus principales mecanismos para adaptarse al estrés salino son el 
mantenimiento de altas concentraciones de $\mathrm{K}^{+}$y la acumulación de prolina en las hojas.

Por otra parte, se analizaron en invernadero 24 genotipos locales de $P$. vulgaris de España durante dos temporadas consecutivas. De cada genotipo, se cultivaron cinco plantas y se caracterizaron (17 rasgos cuantitativos y 15 cualitativos) utilizando los descriptores del IBPGR. Los datos se analizaron estadísticamente mediante análisis de varianza (ANOVA), análisis de componentes principales (PCA) y análisis de conglomerados. Los resultados obtenidos indican una alta variabilidad para la mayoría de los rasgos, especialmente los relacionados con el rendimiento y sus componentes. El PCA y el análisis de conglomerados separaron las variedades locales de acuerdo con el color de la semilla, el rendimiento y los rasgos de la vaina y la semilla relacionados con el rendimiento. Numerosos rasgos exhibieron interacciones entre el genotipo y el medio ambiente. La mayoría de las accesiones alcanzaron mayores rendimientos en primavera, en la que la radiación solar favorece la fotosíntesis y, en consecuencia, la fotoasimilación.

Además, se analizaron las respuestas a los tratamientos por déficit hídrico y estrés salino, en cuanto a inhibición del crecimiento y contenido de prolina foliar (Pro), en 47 genotipos de Phaseolus vulgaris de diferentes orígenes. Se realizó un análisis de varianza bidireccional (ANOVA), correlaciones de Pearson y análisis de componentes principales (PCA) en todos los caracteres medidos, para evaluar las respuestas generales al estrés de los genotipos investigados. Para la mayoría de las variables de crecimiento analizadas y Pro, los efectos del cultivo, el tratamiento y sus interacciones fueron altamente significativos $(p<0.001)$; los rasgos morfológicos de las raíces, el diámetro del tallo y el número de hojas se debieron principalmente a una variación incontrolada, mientras que la variación del peso fresco y el contenido de agua de los tallos y las hojas fue inducida claramente por el estrés. Bajo las condiciones experimentales, los efectos promedio del estrés salino sobre el 
crecimiento de las plantas fueron relativamente más débiles que los del déficit hídrico. En ambos casos, sin embargo, la inhibición del crecimiento se reflejó principalmente en la reducción inducida por el estrés del peso fresco y el contenido de agua de los tallos y las hojas. Pro, por su parte, fue la única variable que mostró una correlación negativa con todos los parámetros de crecimiento, pero particularmente con los de tallos y hojas mencionados anteriormente, como lo indican los coeficientes de correlación de Pearson y los PCA. Por lo tanto, en la judía común, una mayor acumulación de Pro inducida por el estrés se asocia inequívocamente con una mayor inhibición del crecimiento; es decir, con una mayor sensibilidad al estrés del cultivar correspondiente. Se propone el uso de Pro como un marcador bioquímico adecuado para exámenes simples, rápidos y a gran escala de genotipos de judía, para excluir los más sensibles, aquellos que acumulan concentraciones más altas de Pro en respuesta a tratamientos de estrés hídrico o salino.

Asimismo, se han analizado las respuestas a la salinidad en seis cultivares de judía común: cuatro variedades locales de España y dos líneas experimentales de Cuba. La prolina fue usada para clasificar la tolerancia de los cultivares, lo que confirma un estudio anterior que informó como más tolerantes al estrés dos de las variedades locales españolas. Las concentraciones de azúcares solubles totales variaron con los tratamientos y entre los genotipos, pero fue difícil evaluar su papel en la tolerancia al estrés de las plantas analizadas. La concentración de sodio en hojas fue la más baja en uno de los dos cultivares resistentes a la sal, y el potasio no varió ni aumentó bajo estrés salino en todos ellos, excepto en el más sensible, donde se registró una caída de este catión por debajo de $150 \mathrm{NaCl}$ mM. Los cambios en el contenido de malondialdehído (MDA) no indicaron peroxidación de la membrana inducida por sal como resultado del estrés oxidativo secundario; en consecuencia, no se detectó acumulación de compuestos fenólicos totales y flavonoides, como 
mecanismo de defensa antioxidante. Estos resultados destacan la confiabilidad del uso de prolina como marcador bioquímico del estrés salino en judía y la importancia del mecanismo relacionado con el transporte de potasio a las hojas para conferir tolerancia al estrés a algunos cultivares de judía. 


\begin{abstract}
Bean (Phaseolus vulgaris L.) originated in the American continent, specifically in the Mesoamerican zone, and its domestication occurred independently in the Mesoamerican area and the Andean zone, giving rise to two well-differentiated gene pools. It was also observed that the wild Andean populations originated from only a few thousand individuals of the wild Mesoamerican populations, which produced a large bottleneck in the formation of the Andean population. During centuries of cultivation in the Iberian Peninsula after their introduction in the 16th century, beans adapted to new environments, evolving numerous landraces.

In this study was also evaluated the resistance to salinity of local Spanish cultivars of Phaseolus Iunatus L. (lima bean). Plants were subjected to various salt treatments and growth and biochemical parameters were determined. It was observed that salt stress reduced the fresh weight of aerial organs, which allowed us to classify the four genotypes according to their tolerance to salinity. The concentration of most photosynthetic pigments remained unchanged, except for carotenoids which were reduced in the least salt tolerant cv. (cultivar) VPH-79. Leaf $\mathrm{Na}^{+}$and $\mathrm{Cl}-$ concentrations increased with increasing salt concentration of irrigation water, but $\mathrm{K}^{+}$remained constant, as in the most tolerant 'BGV-15410', or increased in the other cultivars, resulting in an unchanged $\mathrm{K}+/ \mathrm{Na}^{+}$ratio under stress in two of the selected cultivars. In addition, proline increased in all cultivars, most notably in cv. VPH-79, with the highest absolute concentrations recorded in the most salt tolerant cultivars. Interestingly, these cultivars already had relatively higher proline concentration in unstressed plants. These findings indicate that $P$. Iunatus is moderately salt tolerant and that its main mechanisms for adapting to salt stress are the maintenance of high $\mathrm{K}^{+}$concentrations and proline accumulation in leaves.

In studies conducted in this research project, 24 landraces of $P$. vulgaris from Spain were analyzed under greenhouse conditions during two consecutive seasons.
\end{abstract}


From each genotype, five plants were grown and characterized for 17 quantitative and 15 qualitative traits using IBPGR descriptors. Data were statistically analyzed by analysis of variance (ANOVA), principal component analysis (PCA) and cluster analysis. The results obtained indicated high variability for most of the traits, especially those related to yield and its components. PCA and cluster analysis separated landraces according to seed color, yield, and yield-related pod and seed traits. Numerous traits exhibited genotype-environment interactions. Most accessions achieved higher yields in spring when solar radiation favors photosynthesis and, consequently, photoassimilation. The different response to the changing environment of the set of accessions studied in the present work is of great interest and can be exploited in breeding cultivars adapted to a wider range of environmental conditions.

On the other hand, this study analyzed the responses to water deficit and salt stress treatments, in terms of growth inhibition and leaf proline (Pro) content, in 47 Phaseolus vulgaris genotypes of different origins. Two-way analysis of variance (ANOVA), Pearson's moment correlations and principal component analysis (PCA) were performed on all measured traits to assess the overall stress responses of the genotypes investigated. For most of the growth variables analyzed and Pro, the effects of cultivar, treatment and their interactions were highly significant $(p<0.001)$; root morphological traits, stem diameter and number of leaves were mainly due to uncontrolled variation, whereas variation in fresh weight and water content of stems and leaves was clearly induced by stress. Under our experimental conditions, the average effects of salt stress on plant growth were relatively weaker than those of water deficit. In both cases, however, growth inhibition was mainly reflected in the stress-induced reduction of fresh weight and water content of stems and leaves. Pro, in turn, was the only variable that showed a negative correlation with all growth parameters, but particularly with those of stems and leaves mentioned above, as 
indicated by Pearson's correlation coefficients and PCAs. Thus, in common beans, higher stress-induced Pro accumulation is unequivocally associated with greater growth inhibition; i.e., greater stress sensitivity of the corresponding cultivar. We propose the use of Pro as a biochemical marker suitable for simple, rapid, large-scale screening of bean genotypes to exclude the most sensitive, those that accumulate higher concentrations of Pro in response to water or salt stress treatments.

In addition, responses to salinity were analyzed in six common bean cultivars: four local varieties from Spain and two experimental lines from Cuba. Proline was used to rank the relative tolerance of the cultivars, confirming a previous study that reported two of the Spanish landraces as more stress tolerant. Concentrations of total soluble sugars varied with treatments and among genotypes, but it was difficult to assess their role in stress tolerance of the plants tested. Leaf sodium concentration was lowest in one of the two salt-resistant cultivars, and potassium did not vary or increase under salt stress in all of them, except in the most susceptible one, where a drop of this cation below $150 \mathrm{NaCl}$ mM was recorded. Changes in malondialdehyde (MDA) content did not indicate salt-induced membrane peroxidation as a result of secondary oxidative stress; consequently, accumulation of total phenolic compounds and flavonoids, as an antioxidant defense mechanism, was not detected. These results highlight the reliability of the use of proline as a biochemical marker of salt stress in common beans and the importance of the mechanism related to potassium transport to leaves in conferring stress tolerance to some common bean cultivars. 


\section{Resum}

El fesol (Phaseolus vulgaris L.) es va originar al continent americà, específicament a la zona mesoamericana, i la seva domesticació es va produir de forma independent en l'àrea mesoamericana i la zona andina, donant lloc a dos patrimonis genètics ben diferenciats. També es va observar que les poblacions silvestres andines es van originar a partir de només uns pocs milers d'individus de les poblacions silvestres mesoamericanas, el que va produir un gran coll d'ampolla en la formació de la població andina. Durant segles de cultiu a la Península Ibèrica després de la seva introducció en el segle XVI, les mongetes es van adaptar a nous entorns, evolucionant nombroses varietats locals.

En aquest estudi es van avaluar conreessis espanyols locals de garrofó (fesol llima) i la seva resistència a la salinitat, a on es van exposar les plantes a diversos tractaments de sal, per tal d'avaluar l'efecte de la salinitat en el creixement i el rendiment de l'cultiu. Es van determinar paràmetres de creixement i bioquímics. I es va observar que l'estrès salí va reduir el pes fresc dels òrgans aeris, el que ens va permetre classificar els quatre genotips segons la seva tolerància a la salinitat. La concentració de la majoria dels pigments fotosintètics va romandre inalterada, excepte els carotenoides que es van reduir al cv menys tolerant a la sal. (Conrear) VPH-79. Les concentracions de $\mathrm{Na}^{+}$i $\mathrm{Cl}$ - de les fulles van augmentar amb l'augment de la concentració de sal de l'aigua de reg, però el K+ va romandre constant, com en el 'BGV-15410' més tolerant, o augmentar en els altres cultivars, el que resultar en una relació $\mathrm{K}^{+} / \mathrm{Na}^{+}$sense canvis sota estrès dos dels conreessis seleccionats. A més, la prolina augmentar en tots els conreessis, més notablement en el cV. VPH-79, amb les concentracions absolutes més altes registrades en els conreessis més tolerants a la sal. Curiosament, aquests conreessis ja tenien una concentració de prolina relativament més alta en plantes no estressades. Aquestes troballes indiquen que $P$. lunatus és moderadament tolerant a la sal i que els seus principals mecanismes per 
adaptar-se a l'estrès salí són el manteniment d'altes concentracions de $\mathrm{K}^{+} \mathrm{i}$ l'acumulació de prolina en les fulles.

En estudis realitzats en aquest projecte de recerca es van analitzar en hivernacle 24 races locals de P. vulgaris d'Espanya durant dues temporades consecutives. De cada genotip, es van conrear cinc plantes i es van caracteritzar per 17 trets quantitatius i 15 qualitatius utilitzant els descriptors de I'IBPGR. Les dades es van analitzar estadísticament mitjançant anàlisi de variància (ANOVA), anàlisi de components principals (PCA) i anàlisi de conglomerats. Els resultats obtinguts indiquen una alta variabilitat per a la majoria dels trets, especialment els relacionats amb el rendiment i els seus components. El PCA i l'anàlisi de conglomerats van separar les varietats locals d'acord amb el color de la llavor, el rendiment i els trets de la beina i la llavor relacionats amb el rendiment. Nombrosos trets van exhibir interaccions entre el genotip i el medi ambient. La majoria de les accessions van aconseguir majors rendiments a la primavera, en què la radiació solar afavoreix la fotosíntesi i, en conseqüència, la fotoasimilación. La diferent resposta a l'entorn canviant del conjunt de accessions estudiades en el present treball és de gran interès, i pot ser explotada en cultivars de millora adaptats a una gamma més àmplia de condicions ambientals.

D'altra banda, en aquest estudi es van analitzar les respostes als tractaments per dèficit hídric i estrès salí, pel que fa a inhibició de l'creixement i contingut de prolina foliar (Pro), en 47 genotips de Phaseolus vulgaris de diferents orígens. Es va realitzar una anàlisi de variància bidireccional (ANOVA), correlacions de moments de Pearson i anàlisi de components principals (PCA) en tots els trets mesurats, per avaluar les respostes generals a l'estrès dels genotips investigats. Per a la majoria de les variables de creixement analitzades i Pro, els efectes de l'cultiu, el tractament i les seves interaccions van ser altament significatius $(p<0.001)$; els trets morfològics de les arrels, el diàmetre de la tija i el nombre de fulls es van deure principalment a 
una variació incontrolada, mentre que la variació de l'pes fresc i el contingut d'aigua de les tiges i les fulles va ser induïda clarament per l'estrès. A les nostres condicions experimentals, els efectes mitjana de l'estrès salí sobre el creixement de les plantes van ser relativament més febles que els de el dèficit hídric. En tots dos casos, però, la inhibició de el creixement es va reflectir principalment en la reducció induïda per l'estrès de l'pes fresc i el contingut d'aigua de les tiges i les fulles. Pro, per la seva banda, va ser l'única variable que va mostrar una correlació negativa amb tots els paràmetres de creixement, però particularment amb els de tiges i fulles esmentats anteriorment, com ho indiquen els coeficients de correlació de Pearson i els PCA. Per tant, en els fesols comuns, una major acumulació de Pro induïda per l'estrès s'associa inequívocament amb una major inhibició de l'creixement; és a dir, amb una major sensibilitat a l'estrès de l'conrear corresponent. Proposem l'ús de Pro com un marcador bioquímic adequat per a exàmens simples, ràpids i a gran escala de genotips de fesol, per excloure els més sensibles, aquells que acumulen concentracions més altes de Pro en resposta a tractaments d'estrès hídric o salí.

Al seu torn, s'han analitzat les respostes a la salinitat en sis conreessis de fesol comú: quatre varietats locals d'Espanya i dues línies experimentals de Cuba. Es va utilitzar prolina per classificar la tolerància relativa dels conreessis, el que confirma un estudi anterior que va informar com més tolerants a l'estrès dues de les varietats locals espanyoles. Les concentracions de sucres solubles totals van variar amb els tractaments i entre els genotips, però va ser difícil avaluar el seu paper en la tolerància a l'estrès de les plantes analitzades. La concentració de sodi en fulles va ser la més baixa en un dels dos conreessis resistents a la sal, i el potassi no va variar ni augmentar sota estrès salí en tots ells, excepte en el més susceptible, on es va registrar una caiguda d'aquest catió per sota de $150 \mathrm{NaCl} \mathrm{mM}$. Els canvis en el contingut de malondialdehid (MDA) no van indicar peroxidació de la membrana induïda per sal com a resultat de l'estrès oxidatiu secundari; en conseqüència, no es 
va detectar acumulació de compostos fenòlics totals i flavonoides, com a mecanisme de defensa antioxidant. Aquests resultats destaquen la fiabilitat de l'ús de prolina com a marcador bioquímic de l'estrès salí en fesols comuns i la importància de I'mecanisme relacionat amb el transport de potassi a les fulles per conferir tolerància a l'estrès a alguns conreus de fesols comuns. 


\section{"Investigar es ver lo que todo el mundo ha visto, y pensar lo que nadie más ha pensado".}

Albert Szent-Györgyi 


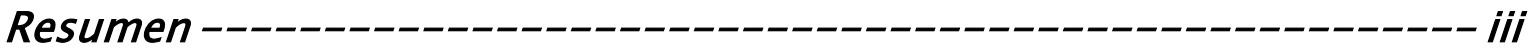

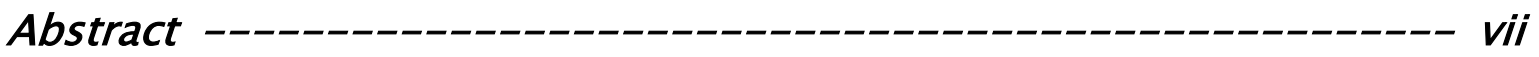

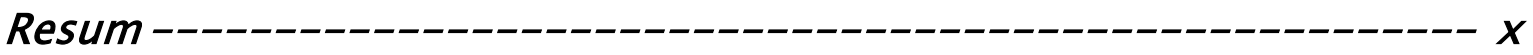

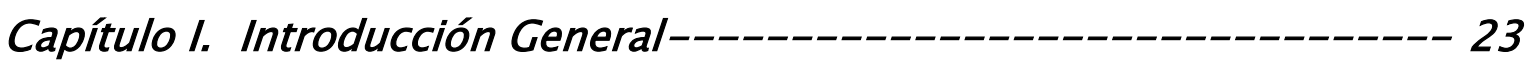

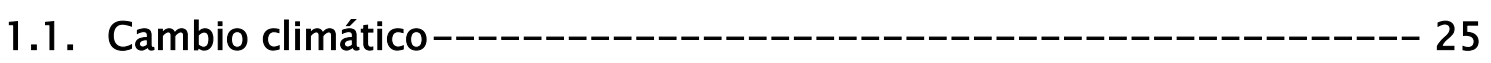

1.2. Influencia del cambio climático en la agricultura ------------------ 26

1.3. Phaseolus vulgaris L., la judía común ------------------ 31

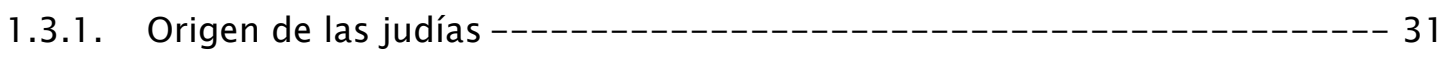

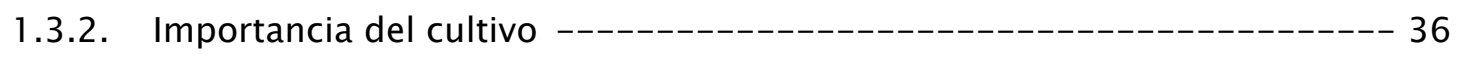

1.3.3. Características botánicas---------------------------------- 37

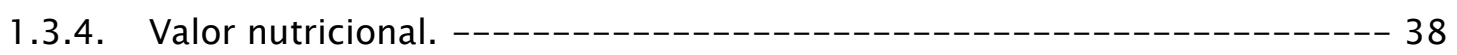

1.4. Phaseolus lunatus L. (el garrofón o judías de Lima) ---------------- 41

1.5. Efectos de la sequía sobre las plantas -------------------------- 42

1.5. Efectos de la salinidad en las plantas-------------------------- 46

1.6. Requerimientos de agua en los cultivos------------------------- 53

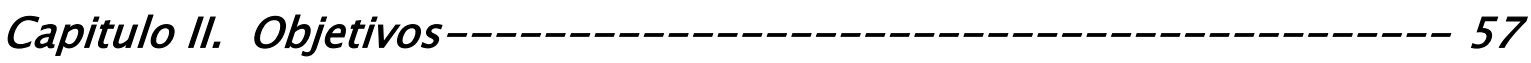

2.1. Objetivo General -- 58

2.2. Objetivos específicos ----------------------------------- 58

Capitulo III. Resultados --

Subcapitulo 3.1. Screening for salt tolerance in four local varieties of Phaseolus lunatus from Spain -------------------------------------- 61

3.1.1. Introduction ---

3.1.2. Materials and Methods -------------------------------------- 65 


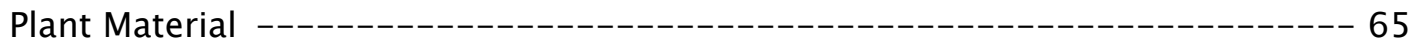

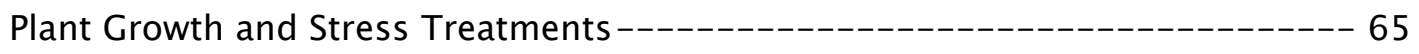

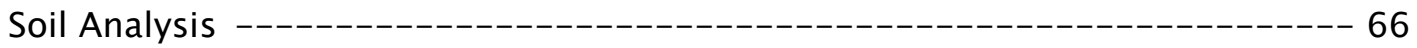

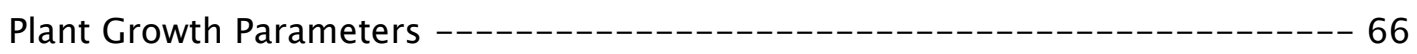

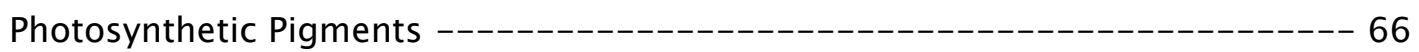

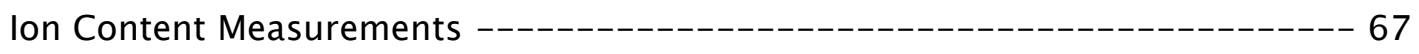

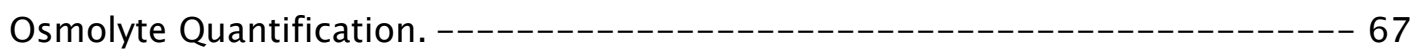

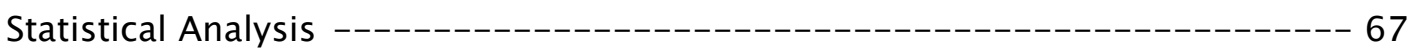

3.1.3. Results -- 68

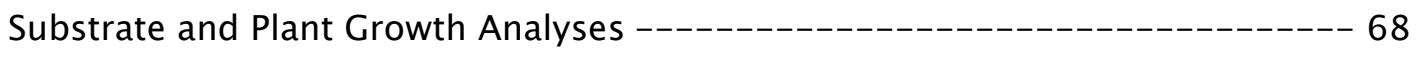

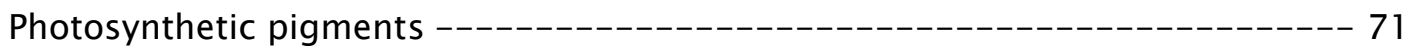

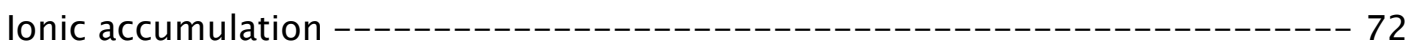

Osmolytes accumulation -------------

Principal component analysis (PCA) -------------------------------- 73

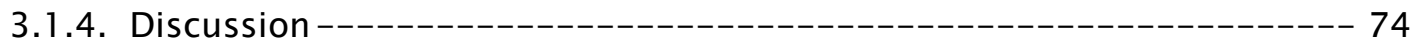

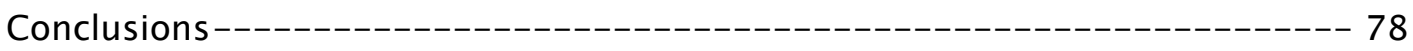

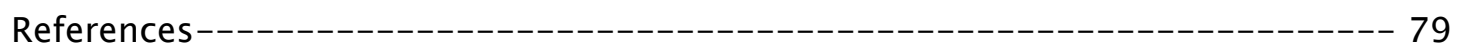

\section{Subcapítulo 3.2. Morphological and Agronomic Characterization of Spanish}

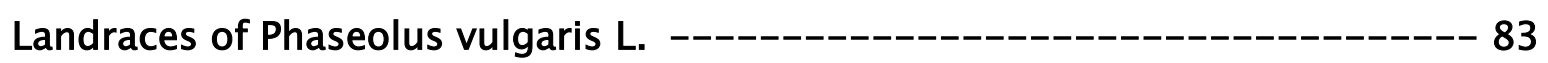

3.2.1. Introduction -- 85

3.2.2. Materials and Methods----------------- 88

Seed Material---_--

Descriptors Used for the Agronomic Characterization ------------------------ 89

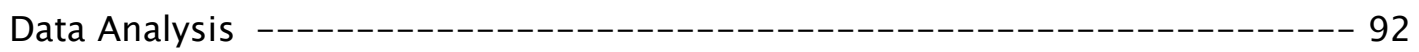

3.2.3. Results ---

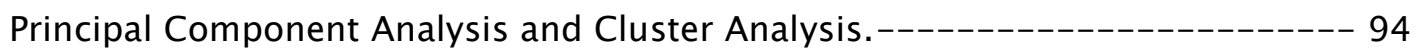

Description of the Variability of the Whole Set of Accessions and of the Groups

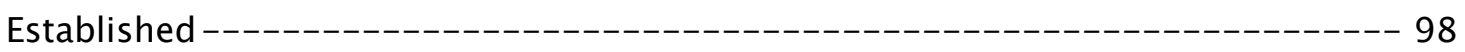

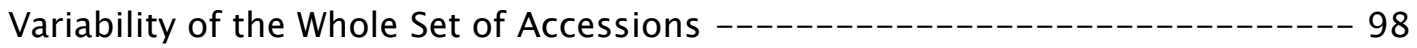

Description of the Three Accessions with Black-Colored Seeds -------------- 104 
Description of the Six Accessions with Brown-Colored Seeds --------------- 105

Description of the Seven Accessions with White-Colored Seeds -------------- 105

Description of the Accessions with Different Seed Colors and of the Accessions

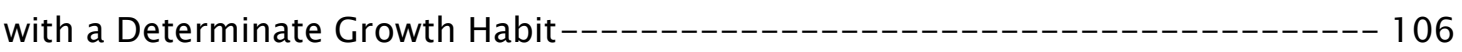

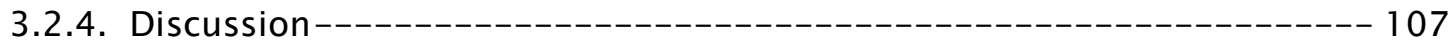

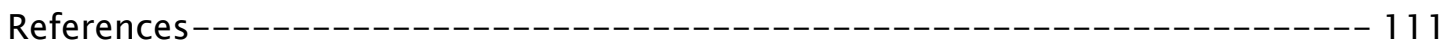

Subcapitulo 3.3. The use of proline in screening for tolerance to drought and salinity in common bean (Phaseolus vulgaris L.) genotypes---------------- 114

3.3.1. Introduction ------- 116

Plant Material -- --

Plant Growth and Stress Treatments---------------------------------- 121

Quantification of Proline Contents --

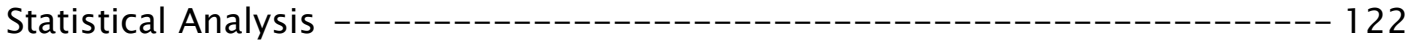

3.3.3. Results----

Analysis of Variance of Registered Traits ------------------------------- 123

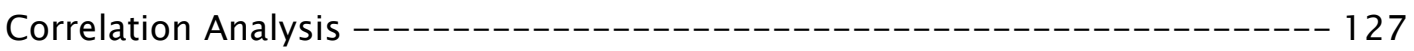

3.3.4. Discussion--------- 133

3.3.5. Conclusions --

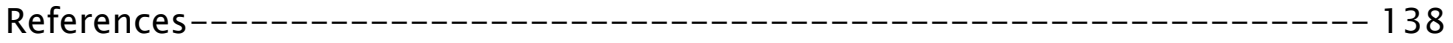

Subcapitulo 3.4. Role of active transport of potassium to leaves in the mechanisms of tolerance to salinity in common bean (Phaseolus vulgaris L.) - 144

3.4.1. Introduction ------------------------------------------------ 146

3.4.2. Materials and Methods----- 148

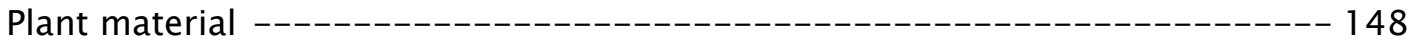

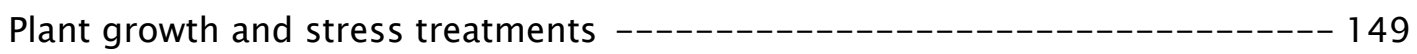

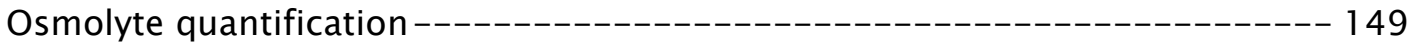

Monovalent ions measurements ----------------------------------- 150

MDA and non-enzymatic antioxidants quantification---------------------- 150

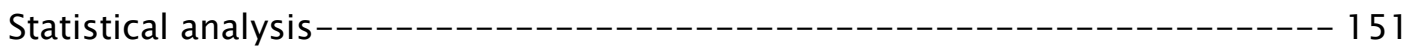




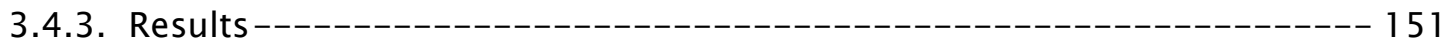

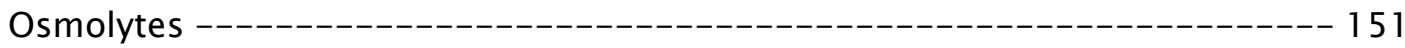

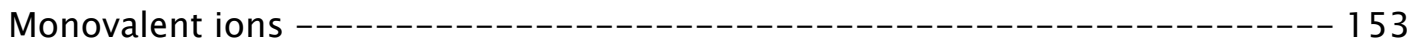

MDA and chemical antioxidants quantification --------------------------- 153

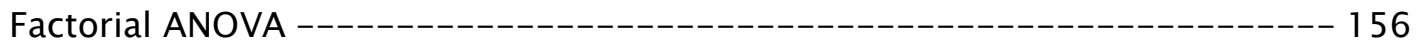

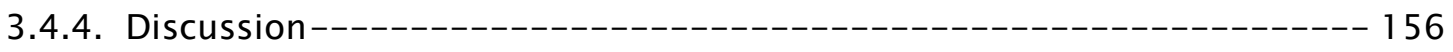

3.4.5. Conclusion --

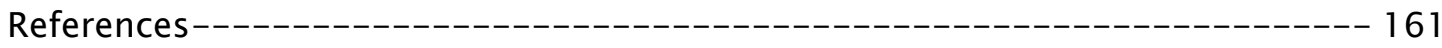

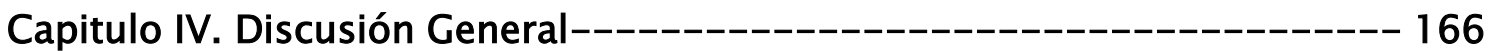




\section{Lista de Figuras}

Fig. 1. Representación de la distribución geográfica de los clúster identificados por el análisis de conglomerados bayesianos realizado por Bitocchi et al. (2012). ----36 Fig. 2. Efecto del estrés hídrico en plantas y posibles respuestas. --------------43

Fig. 3. Efecto de la salinidad del suelo en plantas. -----------------------48

Fig. 4. Leaf monovalent ions contents ( $\mu \mathrm{mol} \mathrm{g}-\mathrm{l} \mathrm{DW}$ ) and $\mathrm{K}^{+} / \mathrm{Na}^{+}$ratios in plants of the four Phaseolus lunatus cultivars, grown for three weeks in the presence of the indicated $\mathrm{NaCl}$ concentrations. -------------------------------------72

Fig. 5. Leaf osmolyte contents in plants of the four Phaseolus lunatus cultivars, grown for three weeks in the presence of the indicated $\mathrm{NaCl}$ concentration. ------------73

Fig. 6. Principal Component Analysis (PCA).--------------------------- 74

Fig. 7. Geographic origin of the 24 Phaseolus vulgaris cultivars.----------------88

Fig. 8. Solar radiation registered in the greenhouse during the autumn (a) and spring trials (b) ------------------------------------------------------------ 90

Fig. 9. Seed morphology of the 24 P. vulgaris accessions. --------------------93

Fig. 10. Loading plot of the principal component analysis (PCA) conducted with the quantitative traits analyzed in 24 accessions of $P$. vulgaris. Abbreviations are as in Table 6. ------------------------------------------------------- 97

Fig. 11. Scatter plot of the PCA scores. -------------------------97

Fig. 12. UPGMA (unweighted pair group method with arithmetic mean) phenogram of the 19 accessions of Phaseolus cultivated in two consecutive seasons based on 17 quantitative descriptors.-------------------------------------------------98

Fig. 13. Pod traits of the 24 P. vulgaris accessions evaluated. ------------------99

Fig. 14. Seed traits of the 24 P. vulgaris accessions evaluated. -------------- 104

Fig. 15. Heatmap of Pearson moment correlation coefficients ( $r$ ) between the analysed traits in Phaseolus vulgaris cultivars submitted to two weeks (a) and three weeks (b) of water and salt stresses. -------------------------------------------- 128

Fig. 16. Loading plot of the principal component analysis (PCA) conducted with the analysed traits, in P. vulgaris cultivars subjected to control, water deficit and salt stress treatments. --------------------------------------------------- 131

Fig. 17. Scatter plot of the PCA score ------------------------------ 132

Fig. 18. Plants exposed to saline stress treatments--------------------- 149 
Fig. 19. Variation of osmolytes contents in response to salt stress in the six cultivars of common beans analysed; (A) Proline; (B) Total soluble sugars-------------- 152

Fig. 20. Monovalent cation content variation in response to salt stress in the six cultivars of common beans analysed; (A) Sodium; (B) Potassium.-------------- 154

Fig. 21. Malondialdehyde content variation in response to salt stress in the six cultivars of common beans analysed--------------------------------- 154

Fig. 22. Variation in antioxidant compounds contents in response to salt stress in the six cultivars of common beans analysed; (A) Total phenolic compounds; (B) Total flavonoids---------------------------------------------------------- 155 
Tabla 1. Características botánicas de Phaseolus vulgaris L----------------------38

Tabla 2. Composición básica y ácidos grasos que constituyen la semilla de P. Vulgaris

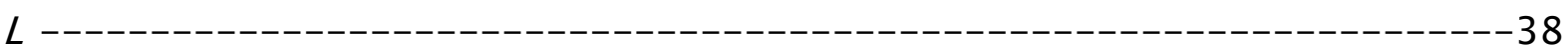

Table 3. Effect of salinity on electric conductivity in the pots and on plant growth parameters, for the four Phaseolus lunatus cultivars. Means followed by SE $(n=5)$. Different letters indicate significant differences within each cultivar according to the Tukey's test $(\alpha=0.05)$. $\rho$ values according to one-way ANOVA ----------------69

Table 4. Significance of variation ( $P$ values) according to two way ANOVA testing the effect of treatment (Variable 1) and genotype (Variable 2) and their interactions for all morphological and biochemical traits analysed. $-70$

Table 5. Effect of salinity on photosynthetic pigments (Chla, chlorophyll a; Chlb, chlorophyll b; Caro, carotenoids) contents of plants of the four Phaseolus lunatus cultivars. Means followed by $S E(n=5)$. Different letters indicate significant differences withing each cultivar according to the Tukey's test ( $\alpha=0.05)-------71$

Table 6. Quantitative and qualitative traits in the 24 Phaseolus vulgaris accessions. IBPCR-International Board for Plant Genetic Resources. $-90$

Table 7. Two-way analysis of variance (ANOVA) of cultivar and cycle effects and their interactions for $-93$

Table 8. Correlation coefficients between the first three principal components (PCS) and the morphological descriptors. $-95$

Table 9. Descriptive statistics for quantitative traits in each of the established groups and the whole set of accessions (number of accessions). Autumn growing season. Units of quantitative traits are as defined inTabla 6. CV-coefficient of variation 100 
Table 10. Descriptive statistics for quantitative traits in each of the established groups and the whole set of accessions (number of accessions). Spring growing season Units of quantitative traits are as defined in Tabla 6.

Table 11. Origin of the analysed Phaseolus vulgaris accessions and duration of the applied stress treatments.

Table 12. Two-way analysis of variance (ANOVA) of cultivar, treatment and their interactions for the parameters considered. Numbers represent percentages of the sum of squares at the $5 \%$ confidence level. Abbreviations

Table 13. Mean values and percentages with respect to the control (\%) of traits measured in Phaseolus vulgaris cultivars after two and three weeks of control (C), water stress (WS) (withholding of irrigation) and salt stress (SS) (150 mM NaCl) treatments.

Table 14. Component weights in the PCA performed on cultivars subjected to two and three weeks of treatments.

Table 15. Origin of the common bean cultivars analysed.

Table 16. Percentages of the sum of squares (SS) from the two-way analysis of variance (ANOVA) of cultivar, treatment, and their interactions, for the indicated parameters. 
Introducción General

Capítulo I. Introducción General 


\section{Introducción General}

Este capítulo comienza con un resumen de la influencia del cambio climático en la agricultura actual y cómo afecta a la producción en una población creciente, en la que se estima que para 2050 la población mundial aumentará a 10.000 millones de personas, mientras que la producción de alimentos disminuye debido al cambio climático. Se prevé que para ese mismo año los sistemas agrícolas tendrán que producir un 60\% más de lo que producían en 2005/2007; también se considera que la agricultura es un motor del cambio climático y contribuye al 19-29\% de las emisiones antropogénicas de gases de efecto invernadero.

El cambio climático afectará a la productividad de los cultivos y tendrá un impacto negativo en la idoneidad ecológica. Los aspectos más importantes del cambio climático con respecto a estos efectos están relacionados con la disponibilidad de agua, el estrés térmico y la salinidad. Numerosas investigaciones realizadas a lo largo de varios años han permitido conocer los mecanismos fisiológicos que facilitan el mantenimiento de la productividad en respuesta a la sequía, las inundaciones, la salinidad y el estrés térmico. En efecto, se han sentado las bases para iniciar el desarrollo de variedades de cultivo de élite preparadas para el eventual cambio climático y para satisfacer las necesidades de seguridad alimentaria de una población creciente. Es vital que los esfuerzos de la biotecnología y la mejora genética para aprovechar estos mecanismos se aceleren en la próxima década. Sin embargo, quienes se ocupan de la mejora de los cultivos deben abordar estos esfuerzos con cautela y asegurarse de que los mecanismos potencialmente aprovechados sean viables en el contexto de un entorno que cambia dinámicamente.

También se aborda el estrés hídrico y salino y su efecto en la producción de cultivos hortícolas como la judía, así como un resumen del origen y las características botánicas y el valor nutricional del cultivo. 


\section{Introducción General}

\subsection{Cambio climático}

El marcado aumento de los cambios antropogénicos persistentes en los ciclos biogequímicos de la Tierra, comenzando con la revolución industrial a fines del siglo XVIII y evolucionando aún más rápido con la "Gran Aceleración" de mediados del siglo $X X$, ha impulsado la propuesta de una nueva época geológica denominada Antropoceno (Le et al., 2011; Lewis y Maslin, 2015; Ogden et al., 2015; Waters, 2016). Los efectos combinados del rápido crecimiento de la población, la industrialización y la globalización en el Antropoceno han permitido las mayores ganancias en el nivel de vida de la historia, al mismo tiempo que han creado los cambios antropogénicos más dramáticos en el medio ambiente. En la relativamente corta duración del Antropoceno hasta ahora, la actividad humana ha alterado numerosos procesos naturales, incluidos los ciclos de nutrientes, la dinámica del agua, la erosión, la extinción de especies y los patrones climáticos globales (GayathriIlangumaran et al., 2018). Sin embargo, es en las últimas décadas cuando aumentan las alteraciones de todos los parámetros climáticos debido al calentamiento global. El quinto Informe del IPCC (2014) concluye que "la influencia humana en el sistema climático es clara y va en aumento, y sus impactos se observan en todos los continentes. Si no se le pone freno, el cambio climático hará que aumente la probabilidad de impactos graves, generalizados e irreversibles en las personas y los ecosistemas". El cambio climático es un fenómeno inducido por el aumento de gases invernadero en la atmósfera, y el $\mathrm{CO}_{2}$ emitido por el ser humano. Se presenta un elevado impacto ambiental, por causas del cambio climático, por la influencia de los eventos climáticos extremos.

Los datos sobre los países en el CRI (Global Climate Risk Index) 2020 muestran cuán destructivas pueden ser las precipitaciones extremas, a saber, a través de las inundaciones y deslizamientos de tierra, que han afectado a muchas regiones del sur y sudeste de Asia y África. Se espera que aumenten las precipitaciones extremas a 


\section{Introducción General}

medida que el calentamiento global intensifica el ciclo hidrológico global. Por lo tanto, se espera que los eventos de precipitación aumenten en intensidad a un ritmo más alto que los cambios medios globales en la precipitación total como lo describen Donat et al. (2016). Además, esos aumentos se esperan tanto en regiones húmedas como secas (Donat et al. 2016). Un estudio por Lehmann et al. (2015) refuerza -el vínculo científico entre los eventos de lluvia récord desde 1980 y el aumento de las temperaturas. Según los científicos, la probabilidad de que un nuevo evento de lluvia extrema sea causado por el cambio climático alcanzó el 26\% en 2010 (Lehmann et al. 2015). Un estudio reciente de Blöschl et al. (2017) concluye que el momento de las inundaciones está cambiando debido al cambio climático. La temperatura media mundial aumentó $0.85^{\circ} \mathrm{C}$ entre 1880 y 2012 y se estima que seguirá en aumento en $0.2^{\circ} \mathrm{C}$ en los siguientes años (IPCC, 2014). Así mismo la concentración global de dióxido de carbono atmosférico $\left(\mathrm{CO}_{2}\right)$ pasó de 284 ppm a 397 ppm entre 1832 y 2013. Probablemente este aumento afecte a los cultivos y la biología de las plagas asociadas (Ziska, et al., 2011). El sector de la producción primaria es el de los más afectados negativamente por el impacto directo del cambio climático (Al-Kaisi et al.,2012; Lai et al, 2012.).

\subsection{Influencia del cambio climático en la agricultura}

La variabilidad climática explica casi el $60 \%$ de las variaciones en los rendimientos, por lo tanto, un factor crucial que influye en la producción de alimentos y los ingresos de los agricultores (Osborne \& Wheeler 2013; Ray et al., 2015; Matiu et al., 2017). El sector agrícola se encuentra en la intersección de tres grandes desafíos. En primer lugar, todos los aspectos de la seguridad alimentaria se ven afectados por el cambio climático (Porter et al., 2014) y se necesitan esfuerzos de adaptación para lograr la seguridad alimentaria y asegurar los medios de vida rurales. En segundo lugar, incluso cuando los impactos climáticos crecientes (en gran medida negativos) se están sintiendo en los sistemas agrícolas, ganaderos y pesqueros (Porter et al., 2014), 
Introducción General

los sistemas agrícolas deben producir un 60\% más de alimentos para 2050 en comparación con los niveles de 2005/07 (Alexandratos, 2012). El sector, que es un empleador importante y una vía para salir de la pobreza (FAO, 2015) deberá mantener un número cada vez mayor de pequeñas explotaciones agrícolas, que se espera aumente a unos 750 millones para 2030 (Campbell, 2014). En tercer lugar, la agricultura (y el sistema alimentario en general) es en sí misma uno de los principales impulsores del cambio climático, y contribuye a nivel mundial del 19 al 29\% de las emisiones antropógenas de gases de efecto invernadero (Vermeulen, 2012). Para lograr el objetivo mundial de limitar el aumento de temperatura a $2^{\circ} \mathrm{C}$, que se adoptó como parte del Acuerdo de París sobre el clima en 2015 (UN, 2015), el sector deberá reducir las emisiones en aproximadamente $1 \mathrm{GtCO}_{2} \mathrm{e} /$ año para 2030 (Wollenberg, 2016), ya que las tecnologías y prácticas actuales solo pueden proporcionar del 21 al 40\% de la mitigación necesaria (Wollenberg, 2016).

La degradación de la tierra y el cambio climático están intensificando los desafíos que han afectado la producción agrícola mundial y la seguridad alimentaria humana durante milenios (Diamond, 2005). Abordar estos desafíos es vital para construir sistemas agroecológicos sostenibles que puedan alimentar a la población mundial en rápido crecimiento. Aunque existe un amplio conocimiento sobre la degradación de la tierra y el cambio climático como fenómenos separados, se sabe menos acerca de cómo es más probable que interactúen en diferentes sistemas agroecológicos y, de manera crítica, cómo las sociedades deben adaptarse simultáneamente a sus impactos (Reed \& Stringer, 2016). La escala de cada desafío por sí sola es enorme. Se estima que la degradación de la tierra afecta $>25 \%\left(37.25\right.$ millones de $\left.\mathrm{km}^{2}\right)$ de la superficie terrestre mundial, en forma de reducción o pérdida de la calidad del suelo debido a cambios físicos y químicos y erosión, y disminución de la productividad biológica y económica (Iniciativa ELD 2015). Estos cambios se están produciendo en los ecosistemas y las tierras agrícolas del mundo, incluidos los pastizales áridos y 
Introducción General

semiáridos (Bestelmeyer et al., 2015), los sistemas agroforestales (Miettinen et al., 2014) y las tierras de cultivo (Karamesouti et al., 2015).

Aproximadamente el $40 \%$ de la degradación de la tierra se ha producido en los países en desarrollo, que se prevé que experimenten el $78 \%$ de la expansión mundial de las tierras secas y el 50\% del crecimiento de la población para el 2100 (Huang et al., 2015). Al mismo tiempo, los riesgos del cambio climático para la agricultura, la biodiversidad y los medios de vida también son enormes, con algunos de los mayores riesgos en las áreas de tierras secas en desarrollo (IPCC, 2014).

El aumento de las olas de calor, las sequías, las inundaciones y la presión de las plagas imponen tensiones directas sobre los cultivos que provocan una disminución de los rendimientos (Gornall et al., 2010). Asimismo, se proyecta que el cambio climático aumentará la desertificación (Salinas y Mendieta, 2013), salinización del suelo (Dasgupta et al., 2015), erosión del suelo (Burt et al., 2015) y el aumento del nivel del mar (Church et al., 2013), lo que lleva a una disminución general de la tierra cultivable. Todas las regiones se verán afectadas por cambios en los patrones climáticos extremos, sin embargo, el tipo del clima variará entre las regiones. Habrá un aumento de las precipitaciones en los trópicos y en latitudes altas, se seca en los subtrópicos y latitudes medias y aumenta en los extremos eventos de precipitación en los trópicos y latitudes medias (IPCC, 2014).

Por otra parte, Canet (2017) afirma que el efecto del cambio climático está reflejado en una reducción de la calidad del agua de riego y la salinización de los suelos tanto por la utilización de aguas más salinas como por un menor lavado de sales por las lluvias. De esta manera se dispondrá de agua de peor calidad al ser más salina y contener más cloruros.

Además, indica cómo se están desplazando algunos cultivos según el cambio de temperatura y disponibilidad del agua unos cultivos van dejando paso a otros que se adapten a las condiciones presentadas. Por ejemplo, la creciente dependencia de 


\section{Introducción General}

los agricultores indios en las aguas subterráneas para hacer frente a la sequía inducida por el clima ha llevado a un rápido declive de la capa freática, y puede empeorar aún más debido al aumento de la variedad del clima a futuro (Fishman, 2018).

Las principales consecuencias del cambio climático se ven reflejada en que a variaciones de temperaturas y precipitaciones se pueden dar modificaciones de los ciclos de cultivos, alteraciones fisiológicas por exposición a temperaturas fuera del umbral permitido, así como deficiencias hídricas y alteraciones del $\mathrm{CO}_{2}$. Esto conlleva que los cultivos se desplacen e igual lo hacen las plagas, las enfermedades, en algunas ocasiones porque lo hacen sus vectores otras por adaptación. Aparecen de esta manera nuevas plagas en zonas que eran desconocidas para ellas o cambian las dinámicas plaga/depredador. En otros casos, el estrés que causan unas condiciones climáticas más desfavorables puede aumentar la sensibilidad de los cultivos a los daños de aquellas.

El cambio climático influye en el inicio y la duración de las temporadas de crecimiento (Fiwa et al., 2014; Zhao et al., 2015; Lemma et al., 2016) y la duración y magnitud del estrés por calor e hídrico en los sistemas de producción agrícola (Lobell et al., 2015; Saadi et al., 2015; Schauberger et al., 2017). La aceleración del crecimiento debido a una temperatura promedio más alta da como resultado una menor interceptación de radiación y una menor producción de biomasa (Rosenzweig y Hillel, 2015). Además, las temperaturas superiores a las óptimas dañan directamente los procesos fisiológicos de los cultivos. Un análisis reciente demuestra el efecto del cambio climático en la producción y el rendimiento de cuatro cultivos principales a nivel mundial, es decir, maíz, arroz, trigo y soja (Wang et al., 2018). Los estudios de rendimiento de cultivos centrados en la India han descubierto que el calentamiento global ha reducido el rendimiento de trigo en un 5.2\% entre 1981 y 2009, a pesar de la adaptación (Gupta et al., 2017). Se prevé que el cambio climático 
Introducción General

reduciría el rendimiento del maíz de secano en un promedio de 3.3 a $6.4 \%$ en 2030 y de 5.2 a $12.2 \%$ en 2050 y el rendimiento de regadío en un 3 a $8 \%$ en 2030 y de 5 a 14\% en 2050 si las variedades actuales se cultivaran (Tesfaye et al., 2017).

La gran preocupación de los agricultores es la disminución de la productividad de sus cultivos por la degradación de los suelos (físicos, químicos y biológicos), así como por aguas de subterráneas y superficiales (calidad y cantidad) y las nuevas plagas (insectos emergentes). Dado que el suelo contiene todos los minerales necesarios para el crecimiento de los cultivos, el manejo del suelo es una de las medidas más cruciales para la adaptación al cambio climático (Bhattacharyya al., 2015; Bedano et al., 2016; Chen et al., 2017; Cui et al., 2017; He et al., 2018). El aumento de la variabilidad climática y de los eventos climáticos extremos, como lluvias intensas y vientos fuertes, pueden acelerar el proceso de erosión del suelo. Asimismo, dado que el suelo contiene todos los minerales necesarios para el crecimiento de los cultivos, el manejo del suelo es una de las medidas más cruciales para la adaptación al cambio climático (Bhattacharyya et al., 2015; Bedano et al., 2016; Chen et al., 2017; Cui et al., 2017; He et al., 2018).

En resumen, el cambio climático es la mayor problemática que enfrenta la agricultura especialmente en países agrícolas. Kalra et al. (2018) afirma que la productividad agrícola puede verse afectada por el cambio climático, debido a cambios de temperatura, precipitación o niveles de $\mathrm{CO}_{2}$ y cambios en los suelos e infestación por insectos plagas. Asimismo, afirman que la probabilidad de eventos extremos ha aumentado en las últimas tres décadas.

El desarrollo de estrategias efectivas mediante las cuales la agricultura pueda adaptarse al cambio climático en las próximas décadas requiere que los agricultores y gobiernos comprendan los riesgos climáticos potenciales que plantea el cambio climático y emprendan medidas para mitigar los efectos del cambio climático (Karimi et al., 2018). De esta manera la adaptación al cambio climático involucra cualquier 
Introducción General

actividad diseñada para reducir la vulnerabilidad y mejorar la resiliencia del sistema (Adger 2006; Vogel y Meyer, 2018) y, por lo tanto, los impactos reales del cambio climático dependen en gran medida de la capacidad de adaptación (Vermeulen et al., 2012).

\subsection{Phaseolus vulgaris L., la judía común}

\subsubsection{Origen de las judías}

Al principio del siglo XX se creyó que la judía común tenía como centro de origen Asia, pero posteriores estudios arqueológicos, botánicos, históricos y lingüísticos concluyeron que ésta se originó entre el norte de México y noreste de Argentina (Gepts y Debouck, 1991). Se han encontrado evidencias de restos arqueológicos como semillas, vainas y plantas enteras (Kaplan, 1981), hallados en los Andes (Perú, Chile, Ecuador y Argentina), en Mesoamérica (México, América Central y sureste de Estados Unidos) y Norteamérica (Nueva York). Actualmente los restos más antiguos datan de 10000-8000 años a.C. procedentes de los Andes y de 6000 años a.C. proveniente de Mesoamérica.

El papel de la diversidad genética es crucial para que las mejoras futuras satisfagan la demanda social de seguridad alimentaria en un escenario de cambio climático. Desde esta perspectiva, es fundamental comprender la estructura y evolución de las especies de cultivos y sus parientes silvestres (Belluci et al., 2013). Brucher (1988), afirma que la judía común actualmente cultivada es el resultado de un proceso de domesticación y evolución (mutación, selección, migración y deriva genética) a partir de una forma silvestre el cuál procede de América, que fue el epicentro de expansión a todo el mundo y en la que se han producido cambios morfológicos, fisiológicos y genéticos (Gepts y Debouck, 1991) como respuestas a las exigencias humanas o del medio ambiente. $\quad P$. vulgaris es una especie diploide autógama verdadera, con 22 cromosomas y un tamaño de genoma haploide que se 
Introducción General

estima entre 587 Mbp y 637 Mbp (Arumuganathan \& Earle, 1991; Bennett \& Leitch 1995, 2010).

Delgado-Salinas et al. (2006) analizaron los espaciadores transcritos internos (ITS) del ADN ribosómico y el locus trnK del cloroplasto, y mostraron que el clado de la corona de Phaseolus no tiene más de 4-6 millones de años. La forma actual de México fue aparente en el Mioceno tardío (hace 5 millones de años), con un gran evento final de vulcanismo por subducción que resultó en el moderno Cinturón Volcánico Trans-Mexicano. Esto sugiere fuertemente que la diversificación de Phaseolus tuvo lugar durante y después de esta importante actividad tectónica (Delgado-Salinas et al., 2006), y por lo tanto evolucionó mucho después del período en que se formó el puente terrestre que conectaba Mesoamérica y Sudamérica, que fue hace 7 millones de años (Coates et al., 2004). Delgado-Salinas et al. (2006) detectaron ocho clados principales dentro de Phaseolus, con el grupo vulgaris como el más antiguo, de ca. 4 millones de años. Este grupo incluye cuatro de las cinco especies domesticadas del género $(P$. vulgaris, $P$. dumosus, $P$. coccineus y $P$. acutifolius). Los parientes más cercanos a $P$. vulgaris son las especies mesoamericanas $P$. dumosus y $P$. coccineus, y estas tres especies juntas son parcialmente cruzables. Las otras especies domesticadas ( $P$. Iunatus, $P$. acutifolius) están relacionadas más lejanamente. En base a datos moleculares de secuencia del gen inhibidor de $\alpha$-amilasa, se considera que $P$. vulgaris divergió de $P$. dumosus y $P$. coccineus hace 2 millones de años (Gepts et al., 1999).

De las cinco especies domesticadas, $P$. vulgaris es la más importante económicamente, ya que es la leguminosa de grano para consumo humano con mayor aportación proteica, vitaminas, minerales y fibra, especialmente en los países menos desarrollados. (http://www.fao.org/index_en.htm, 2010; Brougthon et al. 2003). P. vulgaris es una especie diploide autógrama, con 22 cromosomas y un 
Introducción General

tamaño de genoma haploide que se entre 587 Mbp y 637 Mbp (Arumuganathan y Earle, 1991; Bennett y Leitch, 1995, 2010).

$P$. vulgaris silvestre se distribuye ampliamente desde el norte de México hasta el noroeste de Argentina (Toro et al., 1990), y se caracteriza por dos importantes acervos genéticos ecogeográficos: los de Mesoamérica y los Andes. Estos dos acervos genéticos muestran estructuras geográficas silvestres y domesticadas paralelas, como lo demuestran varios estudios basados 8 diferentes conjuntos de datos, incluida la morfología de las plantas (Singh et al., 1991), proteínas de semillas (Gepts et al., 1986; Gepts y Bliss, 1985), aloenzimas ( Koenig y Gepts, 1989), polimorfismo de longitud de fragmentos de restricción (Becerra-Velásquez y Gepts, 1994), ADN polimórfico amplificado al azar (RAPD, Freyre et al., 1996), polimorfismo de longitud de fragmentos amplificados (AFLP; Papa y Gepts, 2003; Rossi et al., 2009) y repeticiones de secuencia simple (microsatélites, SSR; Kwak y Gepts, 2009).

En los años de 1980, en el norte de Perú y Ecuador se descubrió una población silvestre de P. vulgaris (Debouck et al., 1993). Kami y col. (1995) analizaron una parte del gen que codifica la proteína de semilla Phaseolina e identificaron un nuevo tipo de Phaseolina (tipo I) para esta población del norte de Perú-Ecuador que no estaba presente en los otros acervos genéticos, lo que indica que esta población es un nuevo acervo genético salvaje distinto. El gen de la faseolina de tipo I no porta las repeticiones directas en tándem que están presentes en las accesiones mesoamericanas y andinas. Teniendo en cuenta que las duplicaciones que generan repeticiones directas en tándem son más probables que las deleciones que eliminan específicamente a un miembro de una repetición directa en tándem, Kami et al. (1995) sugirieron que la faseolina tipo I es ancestral de las otras secuencias de faseolina de $P$. vulgaris. Esto surge porque las duplicaciones pueden ocurrir en muchas ubicaciones a lo largo de una secuencia, mientras que las deleciones solo pueden ocurrir en el sitio de las repeticiones directas en tándem. Así, la hipótesis 


\section{Introducción General}

más acreditada sobre el origen del frijol común fue que desde la zona núcleo de la vertiente occidental de los Andes en el norte de Perú y Ecuador, desde donde se dispersó el frijol silvestre hacia el norte (Colombia, Centroamérica y México) y hacia el sur. (sur de Perú, Bolivia y Argentina), lo que resultó en los acervos genéticos mesoamericanos y andinos, respectivamente (Kami et al., 1995). Sin embargo, recientemente, esta hipótesis ha sido cuestionada por diferentes estudios (Rossi et al., 2009; Nanni et al., 2011; Bitocchi et al., 2012, 2013; Desiderio et al., 2013). En particular, Bitocchi et al. (2012) indicaron claramente un origen mesoamericano del frijol común al investigar la diversidad de nucleótidos en cinco fragmentos de genes diferentes en una amplia muestra de $P$. vulgaris silvestre que es representativa de su distribución geográfica.

La primera evidencia de esta afirmación fue la ocurrencia de un cuello de botella antes de la domesticación del acervo genético andino. Esto está respaldado por la mayor diversidad genética detectada para el acervo genético mesoamericano, en comparación con el acervo genético andino, lo que resultó en una pérdida del 90\% de diversidad para el acervo genético andino (Bitocchi et al., 2012).

El segundo resultado novedoso del análisis realizado con datos de secuencia fue la estructura poblacional identificada en Mesoamérica. De hecho, antes del estudio de Bitocchi et al., (2012), incluso si se sabía que el acervo genético salvaje mesoamericano se caracterizaba por una estructura poblacional alta (Papa y Gepts, 2003), nunca se había encontrado una clara distinción entre los grupos y, por lo tanto, Mesoamérica generalmente se consideraba como un acervo genético único. La razón principal de esto probablemente estuvo relacionada con la naturaleza de los marcadores utilizados; de hecho, estudios previos no detectaron claramente ninguna subdivisión poblacional en Mesoamérica debido a la hibridación y recombinación entre los diferentes grupos, lo que redujo el poder discriminatorio de los marcadores moleculares multilocus utilizados (Kwak y Gepts, 2009; Rossi et al., 2009). 


\section{Introducción General}

Como los datos de secuencia son menos propensos a estos factores, Bitocchi et al. (2012) demostraron que las accesiones mesoamericanas se pueden dividir en cuatro grupos genéticos distintos: B1, B2, B3 y B4 (¡Error! No se encuentra el origen de la referencia.). El grupo B1 estuvo representado por accesiones distribuidas en toda el área geográfica, desde el norte de México hasta Colombia. Los otros tres grupos estaban compuestos únicamente por accesiones mexicanas. El grupo B2 se extendió del centro al sur de México, mientras que los grupos B3 y B4 estuvieron presentes en una amplia zona del centro de México (Fig. 1).

Las investigaciones sobre las relaciones entre estos diferentes grupos han demostrado que, sorprendentemente, no existe una distinción clara entre los acervos genéticos silvestres mesoamericanos y andinos, mientras que se encontraron diferentes relaciones de los grupos mesoamericanos con el norte de Perú-Ecuador y los acervos genéticos andinos (Bitocchi et al., 2012). En particular, las accesiones silvestres andinas estaban más relacionadas con las accesiones B3 mesoamericanas, y las accesiones del norte de Perú-Ecuador con las accesiones B4 mesoamericanas (¡Error! No se encuentra el origen de la referencia.). El trabajo de Bitocchi et al. (2012) muestra una clara evidencia de un origen mesoamericano del frijol común, que probablemente estaba ubicado en México, lo cual es consistente con la distribución conocida de la mayoría de los parientes cercanos de $P$. vulgaris. Por lo tanto, ambos acervos genéticos de América del Sur se originaron a través de diferentes eventos migratorios de las poblaciones de Mesoamérica del centro de México. Estos resultados están fuertemente respaldados por los obtenidos a nivel de ADN cloroplástico en una muestra parcialmente superpuesta de accesiones silvestres (Desiderio et al., 2013). Bitocchi y col. (2012) sugirieron que la judía común silvestre del norte de Perú y Ecuador es una población relicta que solo representa una fracción de la diversidad genética de la población ancestral. Considerando que los resultados de Kami et al. (1995) que indicaron que la faseolina tipo I (Phl) es una faseolina 
Introducción General

ancestral son relativamente robustas, la ausencia de este tipo de faseolina en Mesoamérica se debería a su extinción en este acervo genético, o alternativamente, podría estar todavía presente, pero solo no incluido en las muestras analizadas en la literatura.

Fig. 1. Representación de la distribución geográfica de los clúster identificados por el análisis de conglomerados bayesianos realizado por Bitocchi et al. (2012).

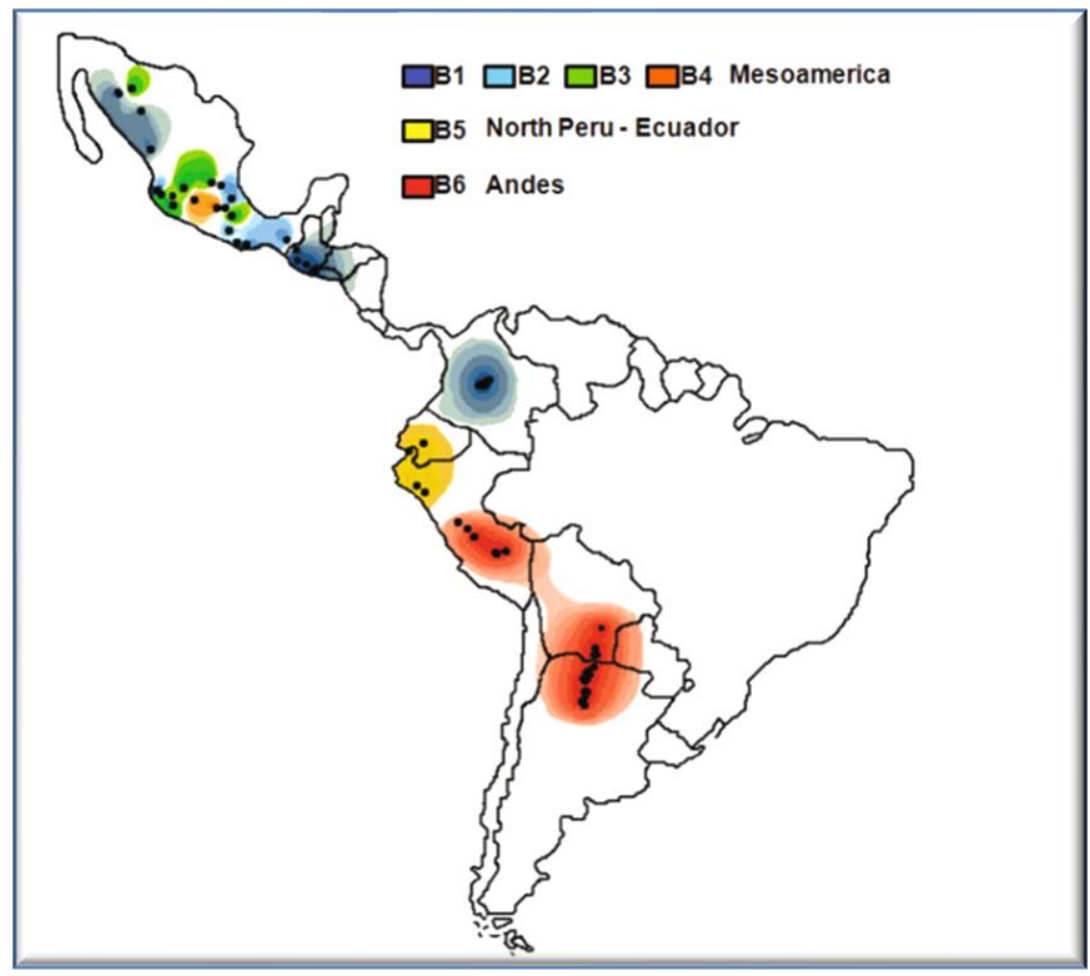

Nota: Consulte la leyenda para ver la correspondencia entre colores y grupos genéticos.

\subsubsection{Importancia del cultivo}

La judía (Phaseolus vulgaris L.), es la leguminosa de grano más importante para el consumo humano por su alto contenido en proteínas, fibra dietética, minerales y vitaminas. Su consumo es en granos secos, granos tiernos o vainas verdes. Las hojas verdes, tallos y las vainas son utilizados como alimento para el ganado y los restos de la planta seca se utiliza como abono orgánico. Otra importancia de las judías es que forman simbiosis con bacterias del género Rhizobium y se utiliza como fertilizantes orgánicos. Su cultivo se expande a nivel mundial. El cultivo es sensible a plagas y enfermedades, por lo cual se requiere una mejora genética para obtener variedades con rendimientos estables y cualidades 
Introducción General

mejoradas, que satisfagan la necesidad alimenticia en un mundo en crecimiento (Rodiño, 2000).

En este cultivo se puede aprovechar el grano y la vaina, además tiene un alto valor proteico, y se comercializa congelado y/o en conserva. Es importante realizar estudios que permitan realizar una mejora genética, así como mejorar las prácticas de cultivo para optimizar las condiciones del cultivo. Los países de la Unión Europea que importan judía verde desde España son: Francia, Alemania, Suiza e Inglaterra.

\subsubsection{Características botánicas}

El cultivo es anual, germinación epigea, con un sistema radicular fasciculado, además hace simbiosis con el hongo Rhizobium phaseoli Dangeard. Presenta tallos delgados, pubescente a glabro, según la variedad son altas o enanas. Sus hojas son trifoliadas con pequeñas estipulas en la base del peciolo. El peciolo de 4-9 cm de largo, foliolos $4.5-15 \mathrm{~cm}$ de longitud, $2.5-6.5 \mathrm{~cm}$ ancho de los foliolos laterales, ovados a ovado-rombico, acuminados, oblicuos: peciolo de $1.5-2.5 \mathrm{~mm}$ de longitud, estipulas de $4 \mathrm{~mm}$ de largo (

\section{Tabla 1).}

Las flores en variedades enanas están organizadas en forma de racimos terminales, mientras que en variedades de enrame son axilares. La flor está constituida por una corola, pentámera y papilonácea, dos pétalos soldados por la base y tres libres. El estandarte es el pétalo más grande, es uno de los libres. El androceo está formado por diez estambres, nueve soldados por la base en forma de tubo y el décimo (vexilar) está libre. El gineceo presenta ovario comprimido, estilo encorvado y un estigma. El androceo y gineceo están envueltos por la quilla, que a su vez favorece el mecanismo de autopolinización. Asimismo, se conoce que las 
Introducción General

anteras se encuentran paralelas al estigma de modo que al producirse la apertura de las anteras el polen cae directamente sobre el estigma (Fueyo, 2004).

Tabla 1. Características botánicas de Phaseolus vulgaris L

\begin{tabular}{ll}
\hline Planta & Indeterminadas/Determinadas \\
\hline Ciclo & Anual \\
Hojas & Trifoliadas \\
Inflorescencia & $1-3$ flores, pedúnculo de $0-5 \mathrm{~cm}$ \\
& longitud. \\
Cáliz & Pubescente, tubo de 2 a $3 \mathrm{~mm}$ de \\
& longitud. \\
Corola & Blanca, púrpura, amarilla o rosa \\
Vexillum & pálido. \\
Quilla & $1-1.9 \mathrm{~cm}$ de longitud, glabro. \\
Frutos & $2.2 \mathrm{~cm}$ de longitud curvado en espiral. \\
& $0.5-30$ mm de longitud \\
\hline
\end{tabular}

\subsubsection{Valor nutricional.}

Las semillas de Phaseolus vulgaris son nutricionalmente muy importantes y tienen las siguientes constituyentes importantes (USDA. National Nutrient Database for Standard Reference Release 27: Basic Report 16032, Beans, Kidney, red, mature seeds, raw. 2015 [cited 2016 Sept 23, 03:45EDT]; Available from: http://ndb.nal.usda.gov/ndb/nutrients/index). (Tabla 2).

Tabla 2. Composición básica y ácidos grasos que constituyen la semilla de P. Vulgaris $L$

\begin{tabular}{llll}
\hline Composición básica (mg/g) & & Ácidos grasos (mg/g) & \\
\hline Lípidos totales & 10.60 & Total saturado & 0.54 \\
Proteínas & 225.30 & Total mono insaturados & 5.86 \\
Carbohidratos & 612.90 & Total Poliinsaturados & 0.0021 \\
Minerales esenciales (mg/g) & & Vitaminas (mg/g) & 0.045 \\
Macrominerales & & Alfa tocoferol (E) & $3.94 \mu \mathrm{g} / \mathrm{g}$ \\
Calcio & 0.83 & Acido ascórbico (C) & 0.0211 \\
Magnesio & 1.38 & Folato & $0.056 \mu \mathrm{g} / \mathrm{g}$ \\
\hline
\end{tabular}




\begin{tabular}{llll}
\hline Sodio & 0.12 & Piridoxina (B6) & 0.00397 \\
Microminerales & & Retinol (A1) & - \\
Hierro & 0.0699 & Riboflavina (B2) & 0.00215 \\
Zinc & 0.0279 & Tiamina (B1) & 0.00608 \\
Fibra dietética total & 0.1520 & Valor calórico & $3.37 \mathrm{kcal} / \mathrm{g}$ \\
\hline
\end{tabular}

En términos químicos la composición del grano de judía tiene un alto contenido en proteínas y bajo nivel en carbohidratos. El 15\% de la ingesta proteica día de una persona con $70 \mathrm{~kg}$ proviene de una porción de 100 g/día de judías (Paredes et al., 2009) El contenido de aminoácidos difiere entre genotipos, condiciones ambientales, manejo del cultivo e incluso la forma de almacenar el grano influye entre otros (Prolla et al., 2010). El grano de judía contiene 16-30\% de proteína, glucidos 55-65\%, fibra 3-8\%, lípidos del 1 al 5\% y minerales entre un 3-5\%. Presenta un alto contenido en calcio y hierro, y vitaminas como tiamina (vitamina B1) y ácido fólico (vitamina B9) su proteína es rica en lisina y pobre en aminoácidos azufrados como la metionina y cisteína. De esta manera una dieta rica en leguminosas con cereales sería un complemento ideal para satisfacer los requerimientos en aminoácidos esenciales en el ser humano (Almeida-Costa et al., 2006). En la composición de las judías, hay presencia de hidratos de carbono de asimilación lenta, fibra y algunos componentes bioactivos minoritarios, muy importantes para la salud (Olmedilla-Alonso et al., 2010), como prebióticos, anticancerosos y antioxidantes. Los polisacáridos derivados y no derivados (fibra dietética) más una variedad de mono, di y polisacáridos se encuentran entre los carbohidratos que con mayores proporciones. Se ha relacionado a los carbohidratos no digeribles que componen la fibra dietética con un efecto protector ante enfermedades cardiovasculares, diabetes, obesidad y enfermedades diverticulares (Kutos et al., 2003). Así, el grano contiene una variedad de carbohidratos bajos y no digeribles, pero su estructura funcional cambia con el remojo y la cocción, aumentando la cantidad de fibra soluble y la digestibilidad (Barampama y Simard, 1995; Reynoso et al., 2009. Se ha relacionado a los carbohidratos no digeribles que 


\section{Introducción General}

componen la fibra dietética con un efecto protector ante enfermedades cardiovasculares, diabetes, obesidad y enfermedades diverticulares (Kutos et al., 2003). Según la evaluación del tiempo de cocción, existe una gran variabilidad en el contenido de proteínas y la dureza del grano entre las variedades mejoradas y las variedades locales. El contenido de proteína en judías nativas de Hidalgo, México, osciló entre 16 y 26,9\%, según lo informado por Muñoz-Velazquez et al. (2009), con variaciones en el tiempo de cocción de 43 a 81 minutos para judías de color vino tinto y amarillo cremoso, y se observó un mayor contenido de proteína más una tasa de digestibilidad in vitro del 95\% en las variedades Canario y Flor de Mayo (RamírezPérez et al., 2012), indican que los contenidos de proteínas oscilan entre 16,3 y 29,2\% con tiempos de cocción de 50 a 141 minutos en genotipos locales de judías de color marrón de Puebla, y niveles de proteína que oscilan entre 21 y $25.8 \%$ con tiempos de cocción de 54 a 141 minutos fueron reportados variedades de frijol local de Guerrero por Solano-Cervantes (Solano-Cervantes et al., 2009). Ciertas variaciones son inducidas por condiciones agroecológicas o de manejo de granos, pero tales cambios no son significativos. Un alto contenido de proteínas constante durante los ciclos de cultivo y los años es una característica de genotipos destacados (Santalla et al., 1999).

Estudios sobre las actividades farmacológicas de $P$. vulgaris, realizados en diferentes extractos, han demostrado su utilidad como analgésico, contra la obesidad (Nyau 2014; Rana, 2016), antibacteriano (Atchibri et al., 2010) anticárginogenico (Oomah et al., 2010; Câmara, 2013), antidiabético (Hayat et al., 2014), antiinflamatorio (Oomah et al., 2010), antioxidante (Hayat et al., 2014), hepatoprotector (Oomah et al., 2010), hipolipidémico (Hayat et al., 2014), y litolítico (Rana, 2016).

A su vez, estudios fitoquìmicos en $P$. vulgaris, revelan la presencia de: antocianinas (Onyilagha y Islam, 2009), brasinoesteroides (Park et al., 2000), ácido cafeico (Oomah et al., 2010), ácido catequico y gálico (Atchibri et al., 2010), 
Introducción General

coumestrol, daidzen (Díaz-Batalla, 2006), delfinidina (Hayat, 2014), equol (DíazBatalla, 2006), ácido ferúlico (Oomah et al, 2010), galactomanos (Agrawal et al., 1968), acido gálico, genisteína (Díaz-Batalla, 2006), hemaglutininas (Agrawal et al., 1968), kaempferol (Díaz-Batalla, 2006), lectinas (Shi Jhon et al., 2007), malvidina (Hayat, 2014), glucósido de mircitina (Reynoso et al., 2006), ácido p-cumárico (Oomah et al., 2010), petunidina (Hayat, 2014), faseolamina (Marshall and Lauda 1975), faseolina (Hayat, 2014), ácido parahidroxibenzoico (Díaz-Batalla, 2006), ácido fítico (Deshpande et al.,1982), fitohemaglutinina (Shi Jhon et al., 2007), proantocianidinas (Aparicio-Fernandez, 2005), proantocianinas (Onyilagha, 2009), quercetina (Díaz-Batalla, 2006), robinin (Onyilagha, 2009), ácido vanílico (DíazBatalla, 2006) entre otros.

\subsection{Phaseolus lunatus L. (el garrofón o judías de Lima)}

P. Iunatus es considerado una fuente de nutrientes muy valiosa en países en desarrollo. Conocido comúnmente como "garrofon", "frijol lima" es la segunda en importancia en su género después de $P$. vulgaris, ambas son de origen neotropical y pueden estar separadas por dos acervos genéticos, el de los Andes y Mesoamericano, que posiblemente estén relacionados con sus respectivos centros de domesticación (Chacon et al., 2005; Serrano-Serrano et al., 2010). Aunque originalmente proviene de Mesoamérica $<<y$ los Andes, actualmente se cultiva en América Latina, Estados Unidos, y muchos países, entre ellos los países mediterráneos dónde se asocia con la gastronomía local (Martinez- Nieto et al., 2020). El mismo autor cita, en las costas de la cuenca mediterránea se cultiva en lugares cálidos y soleados en suelos profundos y bien drenados; sus raíces fuertes permiten que este cultivo se desarrolle en lugares dónde otras legumbres no pueden. Son plantas con crecimiento trepador (Checa et al., 2006). Por otra parte, se están realizando estudios sobre su papel fitosanitario de los glucósidos cianogénicos presentes en semillas de P. Iunatus (Cuny et al., 2019; Gleadow et al., 2002). Según Jones (1988), existen numerosas especies 


\section{Introducción General}

de plantas comestibles que poseen glucósidos cianogénicos y es debido a la función de defensa de estos compuestos y a su papel como sustancias de reserva energética. Asimismo, es una fuente importante de almidón con un contenido entre el 56 al 60\%, y presenta una gran importancia porque se pueden preparar jarabes con alto contenido de glucosa, así como productos horneados y enlatados que requieran calor (Betancur et al., 2001).

\subsection{Efectos de la sequía sobre las plantas}

Producir alimentos en una población en constante crecimiento es el reto de los agricultores e investigadores hoy en día. El problema se genera en que la producción mundial de alimentos ha disminuido por diferentes factores: el cambio climático "estrés abiótico, altas y bajas temperaturas, salinidad, sequía, inundaciones que conllevan a excesos de agua y arrastran metales pesados que en algunas circunstancias causan daños en los suelos, estrés oxidativo, deficiencia de nutrientes en los suelos. Las alteraciones en los patrones de precipitación alteran la disponibilidad de agua en el suelo y afectan también las fechas de floración, y a los factores bióticos como plagas, enfermedades ya sean fúngicas, virales, bactericidas, entre otros en los diferentes sistemas de producción. Como consecuencia la sequía conlleva un aumento en los costes de producción.

La sequía es un fenómeno natural, definido como una anomalía transitoria con valores de las precipitaciones inferiores a las normales en un área determinada durante un periodo de tiempo más o menos prolongado (Wilhite, 2000). Olcina (2011) define la sequía como un fenómeno repetido que evoluciona lenta y progresivamente, con impactos que afectan a territorios donde la demanda es superior a los recursos hídricos disponibles.

La sequía afecta el crecimiento de las plantas, el rendimiento, las relaciones hídricas, membrana integral, contenido de pigmento y fotosíntesis (Praba et al., 2009). A su vez se caracteriza por una disminución en el contenido del agua, 
Introducción General

potencial hídrico y el potencial de presión foliar. Cierre de los estomas, disminución celular y en el crecimiento de la misma (Anjum et al., 2011). Reduce el crecimiento de las plantas, afectando varios procesos fisiológicos y bioquímicos como la fotosíntesis, la respiración, translocación, absorción de lones, azucares, nutrientes, y también procesos hormonales. (Farooq et al., 2009; Prasad et al., 2011). Una sequía severa puede resultar en la detención de fotosíntesis y alteración del metabolismo, finalmente ocasionando la muerte de la planta (Jaleel et al., 2008) (Fig. 2).

Fig. 2. Efecto del estrés hídrico en plantas y posibles respuestas.

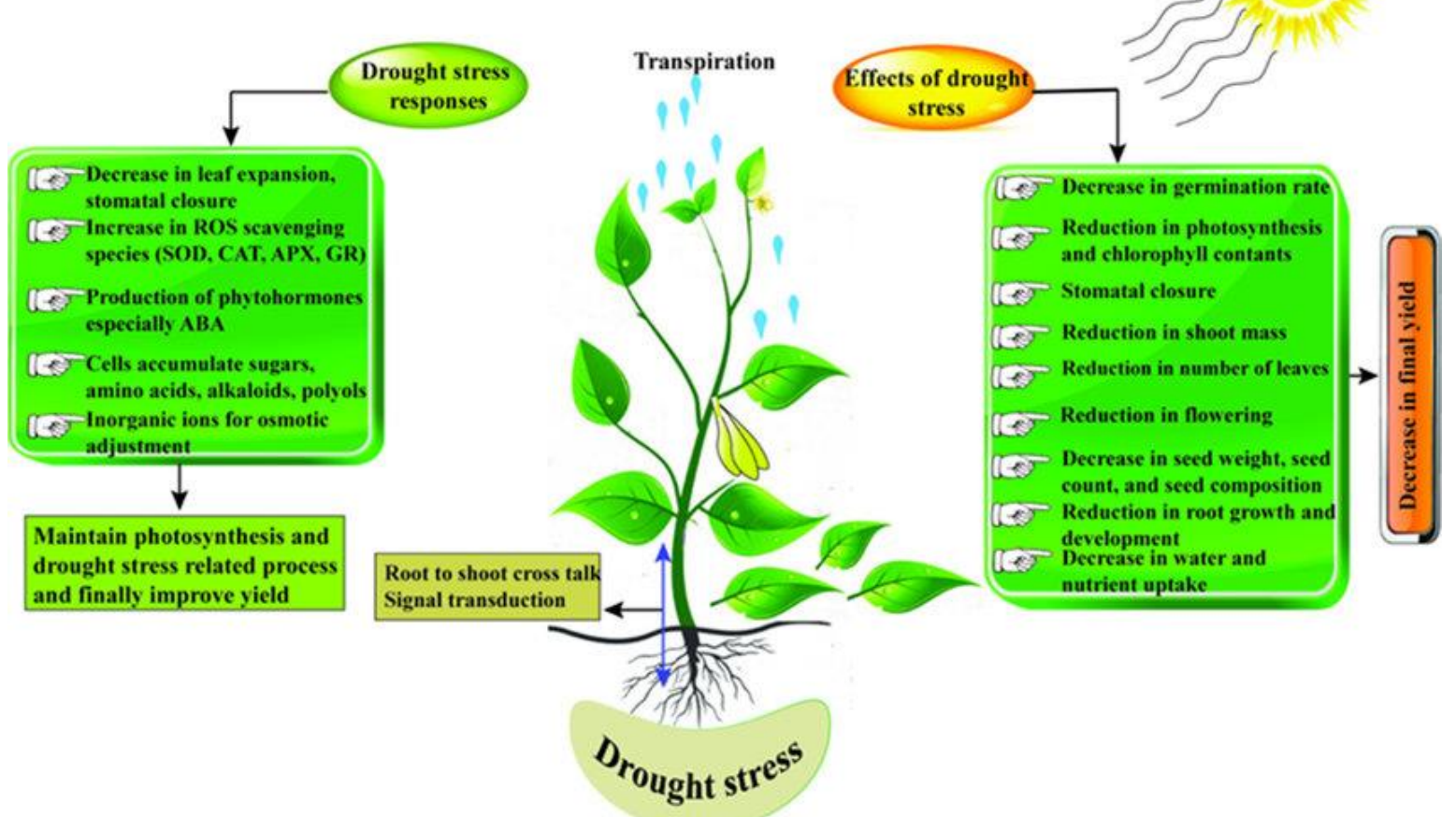

Adaptado de Nadeem et al. (2019)

El estrés por sequía es el factor ambiental más prevalente que limita la productividad de los cultivos (Bray, 1997; Kaur y Asthir, 2017) y el cambio climático global está aumentando la frecuencia de las condiciones de sequía severa (Dai, 2012). La gran diversidad de especies de plantas cultivadas en regiones climáticas que incluyen condiciones de sequía extrema sugiere que, en la naturaleza, las plantas han evolucionado para soportar el estrés por sequía con una serie de adaptaciones 
Introducción General

morfológicas, fisiológicas y bioquímicas (Bohnert, 1995). 'Resistencia a la sequía' es un término más amplio que se aplica a las especies de plantas con características adaptativas que les permiten escapar, evitar o tolerar el estrés por sequía (Levitt, 1980). El 'escape de la sequía' es la capacidad de una especie de planta para completar su ciclo de vida antes del inicio de la sequía. Por lo tanto, las plantas no experimentan estrés por sequía, ya que son capaces de modular su crecimiento vegetativo y reproductivo de acuerdo con la disponibilidad de agua, esencialmente a través de dos mecanismos diferentes: desarrollo fenológico rápido y plasticidad del desarrollo (Jones, 1981). El desarrollo fenológico rápido implica un crecimiento rápido de la planta, produciendo un mínimo número de semillas antes de que se agote el agua del suelo, y se considera que estas plantas no tienen adaptaciones morfológicas, fisiológicas o bioquímicas especiales. Las plantas con mecanismos de plasticidad del desarrollo muestran poco crecimiento durante la estación seca, con muy pocas flores y semillas, pero en la estación húmeda crecen indeterminadamente, produciendo una gran cantidad de semilla. "Evitar la sequía" es la capacidad de las plantas para mantener (relativamente) un mayor contenido de agua en los tejidos a pesar de la reducción del contenido de agua en el suelo (Levitt, 1980). Esto se logra mediante una variedad de características de adaptación que implican la minimización de la pérdida de agua (ahorradores de agua) y la optimización del agua absorción (gastadores de agua). Los consumidores de agua logran un mayor nivel de agua en los tejidos al mantener la absorción de agua a través de un mayor enraizamiento, conductancia hidráulica, etc., bajo estrés por sequía. Por el contrario, los ahorradores de agua utilizan el agua de manera eficaz mediante la reducción de la pérdida de agua al reducir la transpiración, el área de transpiración, la absorción de radiación, etc., bajo estrés por sequía. La "tolerancia a la sequía" es la capacidad de las plantas para soportar un bajo contenido de agua en los tejidos a través de rasgos adaptativos. Estos rasgos adaptativos implican el mantenimiento de la turgencia celular a través 


\section{Introducción General}

del ajuste osmótico y la elasticidad celular, y el aumento de la resistencia protoplásmica (Morgan, 1984).

Aunque la supervivencia de las plantas de judía es muy crítica en las primeras etapas de crecimiento, los mecanismos tienen poca relevancia para aumentar directamente el rendimiento de grano. Por lo tanto, el énfasis en mejorar la resistencia a la sequía de las plantas de cultivo debe basarse en la estabilidad de los componentes del rendimiento y no solo en la supervivencia de las plantas. Hasta ahora, la mayoría de los esfuerzos para mejorar el rendimiento de grano bajo estrés por sequía se centran en rasgos secundarios como la arquitectura de la raíz, el potencial hídrico de las hojas, el ajuste osmótico y el contenido relativo de agua en la etapa vegetativa, que a menudo no están muy correlacionados con el rendimiento de grano (Jongdee, 2002; Pantuwan, 2002). De cara al futuro en los cultivos, el enfoque eficaz de mejora de la sequía debería ser la selección por rendimiento y las características que lo componen en condiciones de estrés por sequía en la etapa reproductiva (Venuprasad, et al., 2007). Además, también se ha dado poca importancia a la mejora simultánea del rendimiento de grano en condiciones normales y de sequía. Se ha sugerido que la selección de tolerancia a la sequía tiene un arrastre de rendimiento en condiciones normales. Se ha propuesto que el potencial de rendimiento de las plantas de cultivo se seleccione simultáneamente en condiciones favorables y de estrés ambiental, ya que existe una correlación positiva entre el potencial de rendimiento en condiciones normales y de estrés por sequía (Guan et al., 2010). La combinación de alto potencial de rendimiento en condiciones normales con buen rendimiento bajo estrés por sequía es el rasgo ideal. La identificación de los mecanismos, rasgos y genes que regulan el rendimiento bajo estrés por sequía que están libres del rendimiento en condiciones normales debe ser el centro de atención de las investigaciones. Por ejemplo, se ha demostrado la regulación del rendimiento tanto en condiciones normales como de estrés por sequía 


\section{Introducción General}

para tres factores de transcripción (TFs) de la familia NAC. Las plantas transgénicas que expresan los TFs de OsNAC5, OsNAC9 y OsNAC10 mostraron un aumento en el rendimiento de grano del 5-26\% en condiciones normales Jeong, et al., 2010, 2013; Redilla, et al., 2012). Sin embargo, en estos estudios, el rendimiento en condiciones normales se ha pasado por alto con mayor énfasis en el rendimiento en condiciones de sequía. Basu et al. (2016), afirman que dos de sus estudios muestran el potencial de mejorar y estabilizar simultáneamente el rendimiento de grano, tanto en condiciones normales como de estrés por sequía, utilizando dos genes reguladores, GUDK y HYR aisladas en arroz (Ambavaran, 2014; Ramegowda, 2014). Estos estudios indican que podría ser ventajoso identificar mecanismos y genes para aumentar el rendimiento de grano que también sean estables o mantenidos en condiciones de estrés por sequía.

Investigaciones realizadas por Zhou et al. (2017) han evaluado el efecto del estrés por calor y sequía en el cultivo del tomate, y los cultivares que difieren en la sensibilidad al calor no mostraron diferencias en la sensibilidad combinada al estrés (estrés/calor: $32 / 26^{\circ} \mathrm{C}$ y sin riego), lo que indica que la selección de tomates con tolerancia combinada al estrés podría no estar correlacionada con la tolerancia al estrés simple. En este estudio, el estrés por sequía tuvo un efecto predominante en el tomate sobre el estrés por calor, lo que explicó por qué la aplicación simultánea de calor y sequía reveló respuestas fisiológicas similares al estrés por sequía. Estos resultados descubrirán la diferencia y el vínculo entre la respuesta fisiológica de los tomates a la sequía, el calor y el estrés combinado y serán importantes para la selección y mejora de cultivares de tomate tolerantes bajo estrés único y combinado.

\subsection{Efectos de la salinidad en las plantas}

Según estimación de la FAO, más del 6\% de la tierra sufre de salinidad (FAO, 2015). El estrés salino es un limitante importante para la productividad de los cultivos teniendo efectos adversos sobre la germinación, el vigor de las plantas y el 
Introducción General

rendimiento de los cultivos (Munns y Tester, 2008). Muchas áreas irrigadas son sensibles a la salinización por el uso de agua salobre debido a los limitados recursos de agua dulce y al aumento de la demanda de alimentos. Más de 45 millones de hectáreas de tierras de regadío han sido dañadas por la salinidad en el planeta y 1,5 millones de hectáreas quedan fuera de producción cada año como resultado de los altos niveles de salinidad en el suelo (Munns y Tester, 2008; El-Ramady et al., 2019). La alta salinidad afecta a las plantas de varias formas: estrés hídrico, toxicidad iónica, trastornos nutricionales, estrés oxidativo, alteración de los procesos metabólicos, desorganización de la membrana, reducción de la división y expansión celular y quenotoxicidad (Abogadallah, 2010; El-Ramady et al., 2018). Juntos, estos efectos reducen el crecimiento, el desarrollo y finalmente el rendimiento de las plantas. Shrivastava y Kumar (2015), relacionan los problemas de la salinidad del suelo con: reducción en la producción agrícola, bajos rendimientos económicos, erosión del suelo, absorción limitada de agua en los suelos, efectos sobre las propiedades fisicoquímicas del suelo, toxicidad iónica, estrés osmótico, deficiencia de algunos nutrientes (N, Ca, K, P, Fe y Zn), estrés oxidativo en las plantas, reducción de la absorción de fósforo de la planta debido a la precipitación de iones de fosfatos y calcio, efectos tóxicos de algunos elementos como el sodio, cloro y boro en las plantas (Fig. 3). 
Introducción General

Fig. 3. Efecto de la salinidad del suelo en plantas.

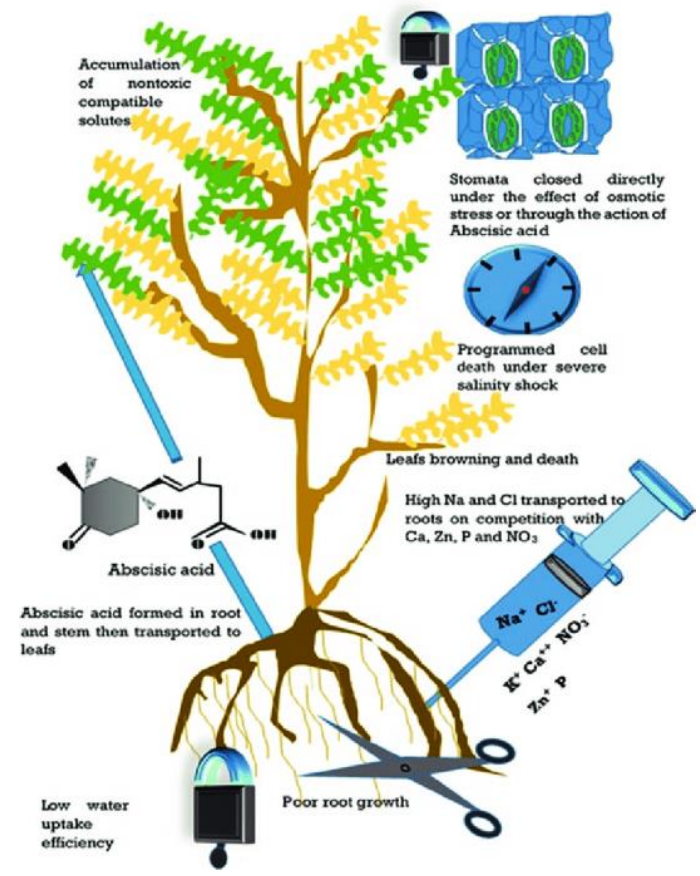

Adaptado de El-Ramady et al. (2018)

Nota: El efecto de la salinidad del suelo en las plantas incluye muchas características tales como una menor eficiencia de absorción de agua; crecimiento deficiente de las raíces; disminuir la absorción de $\mathrm{Ca}, \mathrm{Zn}, \mathrm{P}$ y NO3; pardeamiento de hojas y muerte; cierre de estomas y proceso de fotosíntesis reducido; y acumulación de solutos compatibles no tóxicos.

La salinidad del suelo es un grave problema global que enfrentan las regiones áridas y semiáridas. Este problema necesita un enfoque holístico para mejorarlo y mitigarlo. Por lo tanto, los nuevos enfoques, incluidos los biológicos y los nanomateriales, deberían utilizarse en la búsqueda del desarrollo sostenible. El gran desafío que enfrenta el planeta es que más del 50\% de las tierras cultivables para el año 2050 estarán salinizadas (Naeem et al., 2017). Por lo tanto, los investigadores deben buscar soluciones para superar y mitigar los diferentes riesgos derivados de este desafío.

Por otra parte, el estrés osmótico es la consecuencia preliminar e instantánea del estrés salino, que restringe la absorción de agua y nutrientes por parte de la 


\section{Introducción General}

planta, lo que inhibe la expansión y división celular, así como el cierre de los estomas (Hasanuzzaman et al., 2014; El-Ramady et al., 2018). Sin embargo, el estrés osmótico es continúa durante todo el período de exposición a la sal. El estrés iónico debido a la acumulación de iones, especialmente $\mathrm{Na}^{+} \mathrm{y} \mathrm{Cl}^{-}$, en los tejidos vegetales es el resultado posterior de una exposición prolongada a la sal. Esto conduce a impactos perjudiciales en el crecimiento de las plantas y su dinámica, es decir, desequilibrio de la ósmosis, senescencia prematura, fotosíntesis reducida, hinchazón celular, disminución de la producción de energía, síntomas de toxicidad (clorosis, necrosis), alteración de la síntesis de proteínas e interferencia con muchas actividades enzimáticas (Abogadallah, 2010; Ayala et al., 2014; El-Ramady et al., 2018).

Como respuesta típica a las tensiones ambientales y para asegurar su supervivencia, las plantas han desarrollado una variedad de enfoques para hacer frente a diversos factores de estrés abiótico (Gao et al., 2013). Los mecanismos desarrollados por las plantas incluyen la resistencia a un alto contenido de sal en sus células o el mantenimiento de un bajo contenido de sal en las células mediante la inhibición de la absorción de sal por el sistema radicular. Munns y Tester (2008) propusieron tres posibles respuestas de las plantas a la salinidad: i) la tolerancia al estrés osmótico, ii) la exclusión de $\mathrm{Na}^{+}$de las láminas foliares y iii) la tolerancia tisular. Sin embargo, el grado de tolerancia a la salinidad se debe a la especie vegetal y/o factores ecológicos. También influye el estado de desarrollo de las plantas, como por ejemplo, la mayor susceptibilidad en la fase de germinación, la etapa más sensible a la salinidad en las especies vegetales incluyendo halófitos (Al Hassan et al., 2014), o la etapa reproductiva que en muchas especies representa una fase más sensible a estrés (Alsaeedi et al., 2017).

Uno de los mecanismos más comunes que utilizan las plantas para ajustar su presión osmótica en condiciones estrés salino es la acumulación de solutos compatibles que no son tóxicos a altas concentraciones celulares. Estos solutos 


\section{Introducción General}

compatibles se caracterizan por su bajo peso molecular y alta solubilidad; también difieren entre diferentes especies de plantas (Hannachi y Van Labeke, 2018). La contribución de los osmolitos a la tolerancia al estrés no se limita a su función de ajuste osmótico, ya que tienen múltiples funciones adicionales como osmoprotectores, estabilizando directamente proteínas y estructuras macromoleculares en condiciones de estrés, como eliminadores de ROS o, en algunos casos, como moléculas de señalización implicadas en la inducción de cambios en los patrones de expresión génica (Munns, 2002; Türkan y Demiral, 2009).

Los osmolitos incluyen aminas cuaternarias (por ejemplo, betaínas), azúcares (por ej. manitol, sorbitol y trehalosa) y aminoácidos (por ejemplo, prolina) (Rhodes y Hanson, 1993; McNeil et al., 1999). La prolina (Pro) es el osmolito más común en plantas, que se acumula en respuesta a diferentes tipos de estrés abiótico, incluyendo la sequía y la salinidad, en una variedad de especies vegetales (Szabados y Savouré, 2010; Verbruggen y Hermans, 2008). Además de su papel en el ajuste osmótico celular, Pro tiene funciones adicionales como "osmoprotector"; estabiliza directamente las estructuras subcelulares, como las membranas y las proteínas elimina los radicales libres amortiguando el potencial redox, alivia la acidosis celular y actúa como molécula de señalización en las respuestas al estrés (Hayat et al., 2012, Rana et al., 2017). La prolina también desempeña funciones esenciales en ausencia de estrés, en muchos procesos de desarrollo; por ejemplo, la concentración de prolina aumenta durante la maduración del polen y de las semillas.

La exposición de plantas a estrés salino provoca una mayor generación de especies reactiva de oxígeno, como subproductos, que dañan los componentes celulares (Van Breusegem y Dat, 2006). Las especies reactivas de oxígeno causan la degradación de la clorofila y la peroxidación de lípidos de la membrana, reduciendo la fluidez y la selectividad de la membrana (Verma y Mishra, 2005). La pérdida de clorofila y peroxidación lipídica medida como contenido de malondialdehído, un 


\section{Introducción General}

producto de peroxidación lipídica, son considerados indicadores de daño oxidativo (Del Rio et al., 2005).

En respuesta a la salinidad, las plantas activan sus enzimas antioxidantes (p. ej., catalasa, glutatión reductasa y varias peroxidasas) y acumulan antioxidantes no enzimáticos (como ascorbato, carotenoides, flavonoides y otros compuestos fenólicos etc.) que representan sistemas de desintoxicación para contrarrestar las especies reactiva al oxígeno, y proteger las células del daño oxidativo (Sairam y Tyagi, 2004).

El estrés salino induce la acumulación de ROS que son dañinos para las células vegetales en altas concentraciones. En condiciones de alta salinidad, la producción de ROS aumenta drásticamente y se altera la homeostasis fisiológica de las células. Varios estudios han demostrado que, al igual que otros tipos de estrés abiótico, la salinidad también induce el estrés oxidativo en las plantas a través de un aumento de ROS, como superóxido $\left(\mathrm{O}_{2}^{-1}\right)$, peróxido de hidrógeno $\left(\mathrm{H}_{2} \mathrm{O}_{2}\right)$ y radical hidroxilo (OH) (Mittler 2002). Para mantener el equilibrio entre la producción y la captación de ROS, las plantas desarrollaron sistemas de captación contra ROS, que implican tanto sistemas enzimáticos como no enzimáticos.

En plantas, la principal vía de eliminación de ROS es el ciclo ascorbato-glutatión (AsA-GSH), que consiste en la oxidación y reducción sucesivas de ascorbato, glutatión y NADPH, catalizado por varias enzimas (Mittler, 2002). Las superóxido dismutasas (SOD) son enzimas de primera línea en la eliminación de ROS catalizando la desmutación del radical superóxido $\left(\mathrm{O}_{2--}\right)$ a $\mathrm{H}_{2} \mathrm{O}_{2}$. Las catalasas (CAT) y las peroxidasas de ascorbato (APX) se encargan de reducir el $\mathrm{H}_{2} \mathrm{O}_{2}$ a $\mathrm{H}_{2} \mathrm{O}$, esta última utilizando el ascorbato como donante específico de electrones. Glutatión reductasa (GR) es también una enzima clave del ciclo AsA-GSH utilizando el NADPH como cofactor para catalizar la reducción del glutatión oxidado (GSSG) a glutatión reducido (GSH) (Caverzan et al., 2016). Según Fini et al. (2011) las enzimas antioxidantes 


\section{Introducción General}

representan "la primera línea de defensa contra las ROS" y sólo cuando su actividad disminuye bajo un estrés severo se produce la biosíntesis de los sistemas secundarios no-enzimáticos de eliminación de ROS (incluidos los fenólicos y flavonoides y otros antioxidantes). Los carotenoides son pigmentos con varias funciones en las plantas, además de su papel directo en la fotosíntesis, están involucrados en los mecanismos de defensa del estrés oxidativo (Singh-Gill y Tuteja, 2010). Los compuestos fenólicos también cumplen múltiples funciones en las plantas, como componentes estructurales en las paredes celulares, participando en la regulación del crecimiento y en procesos de desarrollo, así como en los mecanismos de defensa contra el estrés biótico y abiótico (Cheynier et al., 2013). Los flavonoides representan el subgrupo principal y más complejo de los polifenoles con una amplia gama de funciones biológicas, incluida la inhibición de la peroxidación de lípidos (Di Ferdinando et al., 2012).

La judía común (Phaseolus vulgaris) es un cultivo vegetal importante con un alto valor nutricional y representa un mayor consumo e importancia económica en todo el mundo. Como la gran mayoría de las plantas cultivadas, la judía común es una glicófita, sensible a la sal, e incluso niveles de salinidad del suelo relativamente bajos (por debajo de $2 \mathrm{dS}-\mathrm{m}^{-1}$ ) reducen significativamente la productividad del cultivo (Maas y Hoffman, 1977). A una salinidad equivalente a $100 \mathrm{mM}$ de $\mathrm{NaCl}$, el rendimiento medio de vainas por planta en la judía común disminuye en alrededor del 85\% (De Pascale, 1997), aunque algunos cultivares parecen ser significativamente más tolerantes al estrés salino que otros (Gama et al., 2007; Kaymakanova y Stoeva, 2008). Se espera que las pérdidas debidas a la salinidad aumenten en un futuro próximo al menos en las regiones áridas y semiáridas, donde se cultivan ampliamente las legumbres debido a los efectos previstos del cambio climático (IOCC, 2014), y la agricultura de subsistencia en los países en desarrollo se verá especialmente afectada (Morton, 2007). Por lo tanto, un enfoque eficaz para aumentar el rendimiento de los 
Introducción General

cultivos de judías en las próximas décadas podría basarse en la selección de cultivares tolerantes al estrés salino.

\subsection{Requerimientos de agua en los cultivos}

El consumo agrícola de agua se estima que es superior al $80 \%$ del agua disponible en el planeta. Se puede decir que el sector agrícola es el que más consumo de agua requiere por lo cual es importante determinar los requerimientos hídricos de un cultivo a establecer. Los requerimientos de agua varían entre especies y cultivares, a lo largo del crecimiento del cultivo y además entre el ambiente en el que éste se desarrolla. Asimismo, es importante conocer los requerimientos hídricos de los cultivos ya que permite decidir qué prácticas de manejo aplicar para lograr un equilibrio entre la oferta natural de agua y la demanda del cultivo, y además conocer la necesidad de riego. Conocer cómo responden las plantas ante una pérdida de agua a nivel molecular, comprender estos indicadores los cuales detectan la deshidratación y las respuestas adaptativas proporcionan una herramienta para los investigadores del sector ya que se puede determinar la tolerancia a la sequía y eficiencia en el uso del agua y además desarrollar técnicas que permitan aliviar los efectos negativos de la sequía sobre el rendimiento de los cultivos.

Olcina (2001) explica que la sequía supone un desajuste, por defecto, en el ritmo anual de las precipitaciones, de manera que las cantidades que se acumulan en territorios durante las épocas húmedas del año se reducen de forma significativa consolidándose así un déficit hídrico pluviométrico que se traduce sucesivamente en una merma de volúmenes para el abastecimiento. Por su parte, Rico (2004) explica que las sequías ofrecen como denominador común la disminución de lluvias durante periodos de tiempo más o menos prolongados y que con ello restringen la oferta natural de recursos de agua disponible. La Calle (2007) pone de manifiesto que este fenómeno es una situación de escasez motivada por un descenso de las precipitaciones de duración e intensidad inusual. Hecho que no debe confundirse con 


\section{Introducción General}

la aridez o escasez habitual y natural de determinados lugares o la escasez producida por la explotación humana de las aguas.

Por otra parte, Rosadi et al. (2005) afirman que en condiciones de suministro de agua limitado, la tasa de absorción de agua del suelo por las plantas se vuelve menor que la tasa de evapotranspiración (ET), y las plantas de cultivo comienzan a sufrir estrés cuando el agua del suelo cae por debajo del contenido crítico de agua del suelo. El aumento del déficit de agua en el suelo se correlaciona con la reducción del desarrollo de materia seca (Lopez et al., 1996a,b). Asimismo, se conoce que las plantas sólo utilizan para su crecimiento y desarrollo un $5 \%$ del agua que absorben y el $95 \%$ restante se pierde por transpiración y lixiviación (Prakash y Ramachandran, 2000).

El estrés hídrico afecta los componentes del rendimiento de manera diferente dependiendo de cuándo ocurre. El requerimiento neto de agua para un cultivo de judía es de 90 a 100 días y varía de 350 a 500 mm, según el suelo, el clima y el cultivo (Allen et al., 2000). La humedad adecuada del suelo (es decir, cerca de la capacidad del campo) es esencial para una buena emergencia y establecimiento del cultivo. Sin embargo, durante las primeras etapas de crecimiento vegetativo, las necesidades de agua para el cultivo son relativamente bajas, por lo que los agricultores a menudo no riegan durante las primeras 3-4 semanas después de la siembra en el oeste de los Estados Unidos. El requerimiento de agua disminuye drásticamente después del desarrollo de la vaina y la semilla. Además, se esperaría que los cultivares pequeños de maduración temprana tengan un requerimiento neto de agua relativamente menor que los cultivares altos de temporada completa y maduración tardía. Los rasgos de las plantas asociados con las necesidades de agua incluyen la tasa de transpiración, el potencial osmótico, la conductancia estomática y la capacidad de retención de agua, mientras que los factores meteorológicos más importantes que afectan las necesidades de agua de los cultivos son la temperatura y la humedad del aire, la 


\section{Introducción General}

radiación solar y la velocidad del viento (Allen et al., 1998). En regiones cálidas y áridas como las que se encuentran en el sur de Idaho, el frijol seco y otros cultivos usan grandes cantidades de agua para un crecimiento óptimo debido a la profusión de energía y la influencia desecante de la atmósfera. Además, la remoción de vapor se ve afectada por la velocidad del viento porque el movimiento del aire transfiere vapor de agua sobre la superficie de una manera que se correlaciona positivamente con la evapotranspiración (ET, la suma del agua evaporada de la superficie del suelo y el agua transpirada por las plantas).

Entre las diversas características bioquímicas, morfológicas, fisiológicas, de rendimiento de semillas y características relacionadas, los investigadores del frijol seco han descubierto que el rendimiento de semillas medido en ambientes contrastantes estresados por sequía (DS) y no estresados (NS) es la medida integrada más confiable de resistencia a la sequía (White et al. 1994; Ramírez-Vallejo y Kelly, 1998; Abebe y Brick, 2003; Frahm et al., 2004; Terán y Singh 2002). Se ha encontrado que la heredabilidad en sentido estricto del rendimiento de semillas varía entre 0.09 \pm 0.19 y $0.80 \pm 0.15$ dependiendo de la población utilizada, el ambiente de cultivo y el nivel de estrés por sequía (White et al. 1994; Ramírez-Vallejo y Kelly 1998; Singh 1995). En el frijol seco se producen grandes diferencias de resistencia a la sequía. Entre los diversos germoplasmas de frijol seco, el frijol andino de semillas grandes (generalmente $>40$ g 100 peso de semilla - 1) (p. Ej., Riñón rojo oscuro y rojo claro, arándano y riñón blanco) es el más susceptible a la sequía, seguido por el frijol pequeño. de frijol con semillas (p. ej., negro y azul marino con $<25$ g 100 semillas de peso-1) en el oeste de los Estados Unidos (Singh et al., 2001). Los niveles más altos de resistencia a la sequía se encuentran en cultivares de semilla media de las clases de mercado rosa, rojo, pinto y gran norte pertenecientes a la raza Durango (Terán y Singh, 2002). Estos cultivares de la raza Durango (sinónimo de Gene Pool 5; Singh, 1989) fueron inicialmente domesticados en las tierras altas semiáridas del 
Introducción General

centro y norte de México (Singh et al.,1991) y posteriormente introducidos en el oeste de los Estados Unidos por nativos americanos que los cultivaron -sistemas de producción de subsistencia de regadío o secano, no fertilizados y libres de pesticidas durante siglos. Para 1939, se cultivaron 476,344 acres de frijoles de tierras secas principalmente en Arizona, Nuevo México, California, Colorado e Idaho (Mimms y Zaumeyer, 1947). 
Objetivos

Capitulo II. Objetivos 


\section{Objetivos}

\subsection{Objetivo General}

Teniendo en cuenta la tendencia de crecimiento de la población humana y la del consumo de judías a nivel global, queda patente que los estudios sobre la resistencia a estrés abiótico de las especies de este género presentan un elevado interés. Sin embargo, son escasos los estudios que no sólo disciernen entre el grado de tolerancia a estrés de distintos cultivares, sino que también relacionan dicha tolerancia con mecanismos específicos. En este trabajo de investigación nos proponemos analizar la tolerancia al estrés hídrico y salino de variedades locales de Phaseolus lunatus y $P$. vulgaris, conservadas en bancos de germoplasma del CIAT (Centro Internacional de Agricultura Tropical), COMAV (Centro de Conservación y Mejora de la Agrobiodiversidad Valenciana) y el Centro de Bioplantas en Cuba, con potencialidad de presentar una mejor respuesta al estrés que los cultivares comerciales, aunque su productividad sea menor. La hipótesis de partida es que si, como asumimos, algunos de los cultivares ensayados responden mejor a condiciones de estrés, esto podría explicarse por cualquiera de los siguientes mecanismos fundamentales, no mutuamente excluyentes: i) mejor ajuste osmótico reflejado en diferencias cualitativas o cuantitativas en la síntesis de osmolitos; il) evitar o minimizar la toxicidad iónica de la sal por una tasa inferior de absorción de $\mathrm{Na}^{+}$y $\mathrm{Cl}^{-}$; o iii) una mejor respuesta al estrés oxidativo producido bajo condiciones de sequía o salinidad elevada, por activación de mecanismos antioxidantes eficientes, enzimáticos y/o no enzimáticos.

\subsection{Objetivos específicos}

- Identificar cultivares locales de Phaseolus lunatus tolerantes al estrés salino.

- Caracterizar morfológica y agronómicamente cultivares de Phaseolus vulgaris provenientes de Colombia, Cuba y España.

- Identificar la variabilidad existente entre cultivares de dos acervos genéticos el mesoamericano y el andino. 


\section{Objetivos}

- Seleccionar variedades locales de Phaseolus vulgaris con potencialidad de cultivo en condiciones ambientales menos favorables (analizando las características climáticas de sus zonas de origen)

- Comprobar el efecto de tratamientos controlados de estrés hídrico y salino sobre el crecimiento y desarrollo reproductivo de estos cultivares, y seleccionar aquellos relativamente más resistentes a estrés.

- Analizar la acumulación en las plantas de los principales osmolitos: prolina y azúcares totales.

- Estudiar los patrones de absorción de iones monovalentes, $\mathrm{Na}^{+}, \mathrm{K}^{+}$y $\mathrm{Cl}^{-}$ determinando las concentraciones de estos iones en hojas y raíces.

- Comprobar los niveles de estrés oxidativo en las plantas y la posible activación de distintos sistemas antioxidantes. 


\section{$\underline{\text { Resultados }}$}

Capitulo III. Resultados 


\section{Subcapitulo 3.1. Screening for salt tolerance in four local varieties of Phaseolus lunatus from Spain}

Reference:

Sugenith Arteaga, Mohamad Al Hassan, Wijesinghe M. Chaminda Bandara, Lourdes Yabor, Josep V. Llinares, Monica Boscaiu and Oscar Vicente. Screening for salt tolerance in four local varieties of Phaseolus lunatus from Spain. Agriculture 8, 201. DOI: 10.3390/agriculture8120201 


\section{Screening for salt tolerance in four local varieties of Phaseolus lunatus from}

\section{Spain}

Abstract: This study analyses the responses to moderate salinity in four local Spanish cultivars of Phaseolus lunatus (Lima bean). Plants were exposed for three weeks to increasing salinity $(50-150 \mathrm{mM} \mathrm{NaCl})$, under greenhouse conditions. At the end of the treatments, several growth and biochemical parameters were determined. Salt stress mostly affected the fresh weight of aerial organs, and its reduction allowed ranking the four genotypes according to their tolerance to salinity. Photosynthetic pigments contents remained unaltered; only carotenoids were reduced in the least salt-tolerant $c v$. VPH-79. Leaf $\mathrm{Na}^{+}$and $\mathrm{Cl}^{-}$levels increased in parallel to the salt concentration applied, but $\mathrm{K}^{+}$either remained constant, as in the most tolerant BGV-15410, or increased in the others, resulting in an unchanged $\mathrm{K}+/ \mathrm{Na}+$ ratio under stress in two of the selected cultivars. Moreover, proline increased in all cultivars, most notably in $C V$. VPH-79; the highest absolute levels were registered in the more salt-tolerant cultivars, which already showed a relatively higher proline content in non-stressed plants. These findings indicate that $P$. lunatus is moderately salt tolerant and that its main mechanisms to adjust to salinity stress are the maintenance of high levels of $\mathrm{K}^{+}$and proline accumulation in leaves.

Keywords: Lima bean; salt tolerance, growth parameters, ionic homeostasis, osmolytes, proline

\subsubsection{Introduction}

Lima bean, Phaseolus lunatus L., is an important crop, which ranks second among beans - only superseded by common beans, Phaseolus vulgaris - regarding consumption and cultivated land (Lopez-Alcocer et al., 2016). Though originating from Mesoamerica and the Andes (Martinez-Castillo et al., 2014), its area of cultivation has since spread, covering many tropical and subtropical areas around the world; notably in Africa and North America, where the United States is now the leading 
producer of $P$. Iunatus (Baudoin, 2006). In Europe, it is cultivated at a small scale in the Mediterranean countries, mostly in Spain, where is an ingredient of the traditional rice dish "paella".

Following spreading from its original distribution area, the species, as many others crops with American origin, diversified through adaptation and hybridisation into many local genotypes, due to the need to acclimate to different climatic and ecologic conditions (De Ron et al., 2016). However, this diversity is being threatened by contamination, global warming, and changes in land use (urbanisation, industrialisation or cultivation of other, more valuable crops).

The different $P$. Iunatus varieties have been developed, selected, and bred by farmers for many centuries and represent an important source of genetic variability. However, as traditional farming methods are being replaced by industrialised cultivation owned by large agricultural companies, the maintenance of local varieties and hence diversity is being lost (Casado et al., 2009); a loss that is irreversible, and that affects the stability of agro-ecosystems and increases the vulnerability of crops. The reduction of genetic diversity decreases the chance of adapting agriculture to future challenges triggered mostly by global warming (Jackson et al., 2013), especially since the genotype used extensively in agriculture were selected for their high productivity or resistance to some diseases and pests, and generally not bred for increased tolerance to abiotic stress (Fita et al., 2015).

Nonetheless, selection of genotypes better adapted to abiotic stress is recently gaining interest due to the forecasted worsening environmental conditions due to global warming, desertification, and pollution. This is especially important in countries around the Mediterranean, where more extended, frequent and severe drought periods are predicted to occur shortly (IPCC, 2014). This bleak situation is further compounded with the scarcity of water suitable for irrigation, especially in arid and semi-arid areas, making unavoidable the use of low-quality, brackish 
irrigation water. The progressive accumulation of salts dissolved in irrigation water will step up, thus worsening the problem of secondary salinisation that is significantly contributing to the reduction of crop yields worldwide and causing the loss of more than 10 million hectares of arable land every year since the beginning of this century (Fita et al., 2015; Owens et al., 2001). These losses could be explained by the deleterious effects of salt on plants, affecting their water potential and the ability of ion uptake, and causing ion imbalance and toxicity, associated with oxidative stress (Grattan et al., 1999; Parida and Das, 2005). Plant tolerance to salt stress is extremely complex, as numerous interactions take place between stress-induced factors and the physiological and biochemical processes affecting plant development (Gepts and Huang, 2014; Munns and Tester, 2008). All plants, tolerant or not, activate the same basic responses against increased salinity, including inhibition of growth, degradation of photosynthetic pigments, regulation of ion transport, accumulation of compatible solutes, and activation of antioxidant systems (Gepts and Huang, 2014; Szabados and Savoure, 2007; Ashraf and Foolad, 2005; Volkov, 2015). The efficiency in the use and balance of these mechanisms, under specific conditions, will determine the relative degree of salt tolerance of a given species.

The present work focuses on salt tolerance mechanisms in four Spanish landraces of P. lunatus. Studies on the effects of abiotic stress on lima bean are scarce (BayueloJiménez, et al., 2002; Rodrigues Do Nascimento, 2017) and, to our knowledge, this is the first report on the physiological and biochemical responses to salt stress in this species. Our working hypothesis was that genotypes better adapted to salinity, if any could be identified, will rely for their tolerance on some of the conserved mechanisms described above. Therefore, growth responses to saline stress of the four genotypes were correlated with stress-induced changes in leaf levels of photosynthetic pigment, monovalent ions and compatible solutes. Apart from contributing to elucidate the mechanisms of salt tolerance in this species, this study may also have a direct 
practical application for the efficient screening of local landraces to identify tolerant genotypes.

\section{1.2. Materials and Methods}

\section{Plant Material}

Seeds of four local cultivars of P. lunatus from Spain were provided by the Germplasm Bank of COMAV (Institute for Conservation and Improvement of Valencian Agrodiversity, Universitat Politècnica de València, Valencia, Spain). Three cultivars originated from the Province of Valencia (BGV-12848 collected at Benavites; VPH-79 from Benaguacil, and BGV-15410 from Meliana), and one (BGV-1588) originated from Soller, Mallorca, in the Balearic Isles, were used in this study.

\section{Plant Growth and Stress Treatments}

Seeds were individually germinated in $1 \mathrm{~L}$ pots $(11 \mathrm{~cm}$ in diameter) with a standard substrate (peat and vermiculite, 1:1) moistened with half-strength Hoagland nutrient solution prepared with deionised water and with an electrical conductivity (EC) of $\sim 0.8$ dS $m-1$ [19]. When plants acquired one to three pairs of trifoliate leaves and reached a height of about $25 \mathrm{~cm}$, the pots were placed in $55 \times 40 \mathrm{~cm}$ plastic trays $(10$ pots per tray) and salt treatments $(50,100$, and $150 \mathrm{mM} \mathrm{NaCl})$ were started. Control plants were watered twice a week by adding $1.5 \mathrm{~L}$ half-strength Hoagland nutrient solution to each tray, whereas those under salt treatments were watered by adding to the trays the same volume of nutrient solution supplemented with $\mathrm{NaCl}$ at the final concentrations indicated above; trays were thoroughly washed with tap water and then rinsed with deionised water before each new addition of saline solutions. The treatments were applied during three weeks in a growth chamber under the following controlled conditions: long day photoperiod (16 h of light and $8 \mathrm{~h}$ of darkness), temperature of $23 \circ \mathrm{C}$ during the day and $17 \circ \mathrm{C}$ at night, and relative humidity ranging between $50 \%$ and $80 \%$. Five plants (biological replicas) were used per cultivar and per treatment. 


\section{Soil Analysis}

The electrical conductivity $(\mathrm{EC} 1: 5)$ of the substrate was checked at the end of the treatments. Soil samples were taken from the five individual pots per treatment, airdried and then passed through a $2 \mathrm{~mm}$ sieve. A soil: water (1:5) suspension was prepared in distilled water and stirred for one $\mathrm{h}$ at $600 \mathrm{rpm}$ at room temperature. EC was measured with a Crison Conductivity meter 522 (Crison Instruments SA, Barcelona, Spain) and expressed in $\mathrm{dS} \mathrm{m}^{-1}$.

\section{Plant Growth Parameters}

At the conclusion of the experiment, plant materials (roots, stems, and leaves) were sampled separately. The following growth parameters were analysed: root and stem length, basal stem diameter, number of leaves, and fresh weight of roots, stems, and leaves. Part of the harvested leaf material from each sample was weighed (FW), dried in an oven at $65 \circ \mathrm{C}$ for 48 to $72 \mathrm{~h}$ until constant weight, and then reweighed (DW) to calculate the water content, in percentage, of each sample, with the following formula: $W C=[(F W-D W) / F W] \times 100$ (Gil et al., 2014). Fresh material was stored at $-20 \circ \mathrm{C}$ for further analyses.

\section{Photosynthetic Pigments}

Photosynthetic pigments, including chlorophyll a (Chl a), chlorophyll b (Chl b), and carotenoids (Caro), were quantified using $100 \mathrm{mg}$ of fresh leaf material ground in 30 $\mathrm{mL}$ ice-cold $80 \%$ aqueous acetone. The sample was centrifuged $10 \mathrm{~min}$ at 12,000 $\mathrm{rpm}$, the absorbance of the supernatant was measured at 663,646 , and $470 \mathrm{~nm}$, and pigment concentrations were calculated according to validated formulas (Lichtenthaler and Wellburn, 1983):

\footnotetext{
Chl a $\left(\mu \mathrm{g} \mathrm{mL}^{-1}\right)=12.21\left(\mathrm{~A}_{663}\right)-2.81\left(\mathrm{~A}_{646}\right)$, Chl b $\left(\mu \mathrm{g} \mathrm{mL}^{-1}\right)=20.13\left(\mathrm{~A}_{646}\right)-5.03\left(\mathrm{~A}_{663}\right)$, Caro $\left(\mu \mathrm{g} \mathrm{mL}^{-1}\right)=\left(1000 \mathrm{~A}_{470}-3.27[\mathrm{chl} \mathrm{a}]-104[\mathrm{chl} \mathrm{b}]\right) / 227$. Final values were expressed in $\mathrm{mg} \mathrm{g}^{-1} \mathrm{DW}$.
} 


\section{Ion Content Measurements}

Samples were extracted by incubating $0.15 \mathrm{~g}$ of ground dry leaf material in $25 \mathrm{~mL}$ of water for one $\mathrm{h}$ at $95^{\circ} \mathrm{C}$ in a water bath, followed by filtration (Weimberg, 1987). Sodium and potassium were measured in a PFP7 flame photometer (Jenway Inc., Burlington, VT, USA) and chlorides using a chloride analyser.

\section{Osmolyte Quantification.}

Proline (Pro) determination was performed following the classical method described by Bates et al. (Bates and Waldren, 1973), with small modifications introduced in the laboratory (Gil et al., 2014). Fresh leaf material was extracted in a $3 \%(\mathrm{w} / \mathrm{v})$ sulfosalicylic acid solution, then mixed with acid ninhydrin, incubated for one $\mathrm{h}$ at $95^{\circ} \mathrm{C}$, cooled on ice and extracted with two volumes of toluene. After collecting the supernatant, its absorbance was read at $520 \mathrm{~nm}$, using toluene as a blank. Total soluble sugars (TSS) were extracted from dry leaf material with $80 \%(\mathrm{v} / \mathrm{v})$ methanol, mixed on a rocker shaker for 24 hours and then measured spectrophotometrically at $490 \mathrm{~nm}$, following the phenol/sulphuric acid method (Dubois et al., 1956). TSS contents were expressed as "mg equivalent of glucose" per g DW.

\section{Statistical Analysis}

The program Statgraphics Centurion XVI was used for the statistical analysis of the generated data. Before variance analysis, the validity of the normality assumption was checked by the Shapiro-Wilk test and the homogeneity of variance using the Levene test. Once it was established that ANOVA requirements were fulfilled, one-way ANOVA, followed by post-hoc Tukey HSD test, was applied to analyse the effect of salinity within each variety; two-way ANOVAs were used to check the effect of both, treatment and variety, and their interactions. All results were expressed as means $(n=5)$ followed by standard errors (SE), and ANOVA was pe rformed at $\quad 95 \%$ 
confidence level. A Principal Component Analysis (PCA) was performed to analyse the effect of salinity, indicated by the substrates EC, on the four cultivars.

\subsubsection{Results}

\section{Substrate and Plant Growth Analyses}

After three weeks of salt treatments, the electric conductivity of the substrates showed a significant increment in all four studied cultivars and all saline treatments (Table 3). As expected, the highest EC was registered in the pots watered with $150 \mathrm{mM} \mathrm{NaCl}$, recording about a fourfold increase in comparison with EC measured in the respective controls. On the other hand, no significant inter-cultivar differences were detected, as shown in

\section{Table 4}

The morphological parameters analysed in roots (Table 3 ) indicated a high variability between the cultivars (

Table 4). We could not detect any clear trend for changes in the root length, in relation to the applied treatments, as the measurements showed a fluctuation with increasing added salt. Root fresh weight did not vary significantly in the cultivars VPH-70 and BGV-12848, whereas in the remaining two (BGV-1541 and BGV-1588) it increased in the presence of 100 or $150 \mathrm{mM} \mathrm{NaCl}$. On the other hand, root water content was similar among cultivars and did not change significantly in the different treatments. Stem length and stem diameter recorded significant changes under salt stress only in the cultivar BGV-1588, though not progressive with increasing $\mathrm{NaCl}$ concentrations. Stem fresh weight largely varied, not only between genotypes but also between samples, whereas stem water content differed significantly between genotypes - especially in control plants - but not when comparing salt-stressed and non-stressed plants. Therefore, considering changes in root and stem parameters, a tendency of growth reduction with increasing salinity was noticed in the four cultivars, but no clear patterns of variation were observed (Table 3).

The number of leaves diminished significantly in all four cultivars under salinity, and this reduction was most profound in the leafier cultivar $\mathrm{VPH}-79$, which in the 
control had an average of 44 leaves per plant. Leaf FW weight also decreased in all cultivars. Leaf water content did not vary as a consequence of the salt treatment, except for the slight (about 8\%) but significant decrease observed in the cultivar BGV12848 , indicating that $P$. Iunatus is quite resistant to salt-induced leaf dehydration (Table 3).

To gain a better understanding of the effects of salinity on plant growth, the fresh weights of roots, stems, and leaves of each plant were summed and the obtained values were expressed as the percentages of FW reduction with respect to their respective controls (last row in Table 3). In this way, salt-induced growth inhibition for each cultivar and their relative degree of salt tolerance were established. Cultivar $\mathrm{VPH}-79$, with a FW reduction of almost $74 \%$, appeared to be the most sensitive to salinity, followed by BGV-12848, whereas BGV-15410 - which lost only 37\% of the control FW in the presence of the highest $\mathrm{NaCl}$ concentration tested (150 mM) - would be the most tolerant according to this criterion.

Table 3. Effect of salinity on electric conductivity in the pots and on plant growth parameters, for the four Phaseolus lunatus cultivars. Means followed by SE $(n=5)$. Different letters indicate significant differences within each cultivar according to the Tukey's test $(\alpha=0.05)$. $\rho$ values according to one-way ANOVA

\begin{tabular}{clrrrr}
\hline Trait & $\begin{array}{c}\text { Treatment } \\
\text { (mM NaCl) }\end{array}$ & \multicolumn{1}{l}{ VPH-79 } & \multicolumn{1}{c}{ BGV-12848 } & \multicolumn{1}{c}{ BGV-15410 } & \multicolumn{1}{c}{ BGV 1588 } \\
\hline & 0 & $0.40 \pm 0.03 \mathrm{a}$ & $0.33 \pm 0.05 \mathrm{a}$ & $0.28 \pm 0.02 \mathrm{a}$ & $0.47 \pm 0.14 \mathrm{a}$ \\
& 50 & $0.81 \pm 0.12 \mathrm{a}$ & $1.02 \pm 0.11 \mathrm{ab}$ & $1.02 \pm 0.29 \mathrm{~b}$ & $1.09 \pm 0.21 \mathrm{ab}$ \\
Soil & 100 & $1.57 \pm 0.11 \mathrm{~b}$ & $1.39 \pm 0.15 \mathrm{~b}$ & $1.68 \pm 0.07 \mathrm{c}$ & $1.31 \pm 0.19 \mathrm{~b}$ \\
EC $_{1: 5}$ & 150 & $1.82 \pm 0.15 \mathrm{~b}$ & $1.81 \pm 0.44 \mathrm{~b}$ & $1.81 \pm 0.05 \mathrm{c}$ & $1.77 \pm 0.07 \mathrm{~b}$ \\
Root & 0 & $27.20 \pm 3.33 \mathrm{a}$ & $26.60 \pm 1.80 \mathrm{a}$ & $39.75 \pm 3.60 \mathrm{a}$ & $45.203 .82 \mathrm{a}$ \\
length & 50 & $31.50 \pm 1.37 \mathrm{a}$ & $32.50 \pm 1.5 \mathrm{~b}$ & $33.00 \pm 2.58 \mathrm{a}$ & $35.67 \pm 2.40 \mathrm{a}$ \\
(cm) & 100 & $40.00 \pm 1.15 \mathrm{~b}$ & $25.20 \pm 1.95 \mathrm{a}$ & $37.50 \pm 4.33 \mathrm{a}$ & $34.00 \pm 4.97 \mathrm{a}$ \\
& 150 & $27.00 \pm 3.05 \mathrm{a}$ & $30.00 \pm 1.00 \mathrm{~b}$ & $39.003 .90 \mathrm{a}$ & $41.00 \pm 6.54 \mathrm{a}$ \\
& 0 & $4.65 \pm 0.83 \mathrm{a}$ & $3.02 \pm 0.59 \mathrm{a}$ & $2.78 \pm 0.18 \mathrm{a}$ & $2.48 \pm 0.17 \mathrm{ab}$ \\
Root & 50 & $3.54 \pm 0.41 \mathrm{a}$ & $2.81 \pm 0.41 \mathrm{a}$ & $2.59 \pm 0.36 \mathrm{a}$ & $1.99 \pm 0.47 \mathrm{a}$ \\
FW & 100 & $3.67 \pm 0.35 \mathrm{a}$ & $2.73 \pm 0.41 \mathrm{a}$ & $4.17 \pm 0.59 \mathrm{ab}$ & $3.37 \pm 0.80 \mathrm{ab}$ \\
(g) & 150 & $3.81 \pm 1.14 \mathrm{a}$ & $2.52 \pm 0.37 \mathrm{a}$ & $6.24 \pm 1.07 \mathrm{~b}$ & $4.03 \pm 0.56 \mathrm{~b}$ \\
& 0 & $88.60 \pm 0.46 \mathrm{a}$ & $91.18 \pm 1.02 \mathrm{a}$ & $83.71 \pm 1.25 \mathrm{a}$ & $84.08 \pm 6.67 \mathrm{a}$ \\
Root & 50 & $89.09 \pm 0.84 \mathrm{a}$ & $98.87 \pm 0.51 \mathrm{a}$ & $86.26 \pm 2.07 \mathrm{a}$ & $84.03 \pm 0.98 \mathrm{a}$ \\
WC & 100 & $87.64 \pm 0.24 \mathrm{a}$ & $91.01 \pm 0.70 \mathrm{a}$ & $81.83 \pm 4.61 \mathrm{a}$ & $87.74 \pm 0.75 \mathrm{a}$ \\
$(\%)$ & 150 & $88.23 \pm 5.50 \mathrm{a}$ & $89.17 \pm 0.52 \mathrm{a}$ & $85.33 \pm 0.73 \mathrm{a}$ & $87.14 \pm 0.59 \mathrm{a}$ \\
& 0 & $188.56 \pm 0.85 \mathrm{a}$ & $115.00 \pm 12.7 \mathrm{a}$ & $131.40 \pm 11.1 \mathrm{a}$ & $162.20 \pm 11.5 \mathrm{~b}$ \\
& 50 & $162.67 \pm 15.9 \mathrm{a}$ & $150.25 \pm 8.51 \mathrm{a}$ & $148.90 \pm 25.9 \mathrm{a}$ & $121.20 \pm 11.5 \mathrm{ab}$ \\
\hline
\end{tabular}




\begin{tabular}{|c|c|c|c|c|c|}
\hline \multirow{2}{*}{$\begin{array}{l}\text { Stem } \\
\text { length } \\
(\mathrm{cm})\end{array}$} & 100 & $172.83 \pm 11.7 a$ & $147.20 \pm 9.98 a$ & $129.50 \pm 6.85 a$ & $88.20 \pm 5.04 a$ \\
\hline & 150 & $155.33 \pm 21.4 a$ & $115.33 \pm 11.6 a$ & $159.00 \pm 7.37 a$ & $132.75 \pm 21.5 a b$ \\
\hline \multirow{4}{*}{$\begin{array}{l}\text { Stem } \\
\text { diameter } \\
(\mathrm{cm})\end{array}$} & 0 & $5.88 \pm 0.16 b$ & $6.01 \pm 0.09 a$ & $5.00 \pm 0.36 a$ & $4.49 \pm 0.33 a b$ \\
\hline & 50 & $4.75 \pm 0.41 a$ & $5.09 \pm 0.36 a$ & $4.49 \pm 0.21 a$ & $5.03 \pm 0.24 b$ \\
\hline & 100 & $4.91 \pm 0.14 a b$ & $5.36 \pm 0.34 a$ & $5.16 \pm 0.25 a$ & $3.99 \pm 0.11^{\mathrm{a}}$ \\
\hline & 150 & $5.34 \pm 0.29 \mathrm{ab}$ & $4.13 \pm 0.60 a$ & $4.49 \pm 0.21 a$ & $4.92 \pm 0.20 b$ \\
\hline \multirow{4}{*}{$\begin{array}{l}\text { Stem FW } \\
\text { (g) }\end{array}$} & 0 & $30.79 \pm 2.73 b$ & $14.99 \pm 5.12 \mathrm{a}$ & $17.54 \pm 2.08 \mathrm{a}$ & $16.78 \pm 2.85 b$ \\
\hline & 50 & $16.77 \pm 4.12 \mathrm{a}$ & $12.81 \pm 2.78 \mathrm{a}$ & $10.62 \pm 1.87 a$ & $11.79 \pm 1.17 a b$ \\
\hline & 100 & 13.611.24a & $11.65 \pm 1.48 a$ & $11.20 \pm 2.35 a$ & $7.77 \pm 1.12^{\mathrm{a}}$ \\
\hline & 150 & $12.78 \pm 1.33 a$ & $6.96 \pm 0.93 a$ & $13.02 \pm 1.67 a$ & $13.89 \pm 0.79 a b$ \\
\hline \multirow{2}{*}{ Stem } & 0 & $81.22 \pm 0.88 a$ & $85.53 \pm 2.12 \mathrm{a}$ & $84.29 \pm 2.57 a$ & $83.25 \pm 10.55^{\mathrm{a}}$ \\
\hline & 50 & $77.90 \pm 0.76 a$ & $80.93 \pm 2.03 a$ & $83.07 \pm 2.45 a$ & $81.50 \pm 1.36 \mathrm{a}$ \\
\hline \multirow{3}{*}{ (\%) } & 100 & $79.00 \pm 1.47 a$ & $81.01 \pm 0.55 a$ & 83.071.25a & $84.67 \pm 1.03$ a \\
\hline & 150 & $78.28 \pm 1.51 a$ & $81.90 \pm 0.55 a$ & $81.76 \pm 0.57 a$ & $83.37 \pm 0.49 a$ \\
\hline & 0 & $44.80 \pm 2.80 \mathrm{~b}$ & $19.20 \pm 4.02 \mathrm{a}$ & $33.20 \pm 4.04 b$ & $27.20 \pm 3.70 b$ \\
\hline Leaf & 50 & $22.83 \pm 5.61 a$ & $16.25 \pm 4.44 a$ & $18.60 \pm 3.64 a b$ & $19.00 \pm 1.89 a b$ \\
\hline \multirow[t]{2}{*}{ number } & 100 & $17.83 \pm 0.98 a$ & $15.20 \pm 1.15 a$ & $24.67 \pm 3.65 a b$ & $10.60 \pm 1.16 \mathrm{a}$ \\
\hline & 150 & $12.67 \pm 1.45 a$ & $9.33 \pm 1.52 a$ & $13.75 \pm 3.38 a$ & $10.80 \pm 1.73^{a}$ \\
\hline \multirow{2}{*}{ Leaf } & 0 & $61.18 \pm 5.53 b$ & $42.49 \pm 8.25 b$ & $25.05 \pm 3.64 b$ & $20.26 \pm 3.47 b$ \\
\hline & 50 & $26.80 \pm 9.83 a$ & $25.05 \pm 3.64 a$ & $20.95 \pm 3.91 b$ & $13.05 \pm 2.68 \mathrm{ab}$ \\
\hline & 100 & $12.12 \pm 2.44 a$ & $18.85 \pm 2.51 \mathrm{a}$ & $19.23 \pm 4.20 \mathrm{~b}$ & $5.08 \pm 1.90 \underline{a}$ \\
\hline & 150 & $8.89 \pm 1.40 a$ & $7.04 \pm 1.29 a$ & $9.82 \pm 4.16 a$ & $5.08 \pm 1.90 \underline{a}$ \\
\hline \multirow{2}{*}{ Leaf } & 0 & $85.27 \pm 0.18 a$ & $89.88 \pm 2.33 b$ & $86.53 \pm 0.91 a$ & $84.78 \pm 0.60^{a}$ \\
\hline & 50 & $82.63 \pm 2.29 a$ & $85.14 \pm 0.65 a b$ & $87.98 \pm 2.12 \mathrm{a}$ & $84.78 \pm 0.60^{\mathrm{a}}$ \\
\hline \multirow{2}{*}{ (\%) } & 100 & $81.64 \pm 2.26 a$ & $84.66 \pm 0.28 a b$ & $79.24 \pm 10.64 a$ & $85.09 \pm 0.41 \mathrm{a}$ \\
\hline & 150 & $78.66 \pm 3.57 a$ & $83.07 \pm 1.52 a$ & $80.99 \pm 4.18 a$ & $78.89 \pm 6.49 a$ \\
\hline Total & 0 & 0 & 0 & 0 & 0 \\
\hline \multirow{3}{*}{$\begin{array}{l}\text { FW } \\
\text { Reduction } \\
\text { (\%) }\end{array}$} & 50 & 51.25 & 32.77 & 38.21 & 32.09 \\
\hline & 100 & 69.57 & 45.08 & 24.67 & 55.73 \\
\hline & 150 & 73.63 & 59.39 & 36.68 & 41.78 \\
\hline
\end{tabular}

Table 4. Significance of variation (P values) according to two way ANOVA testing the effect of treatment (Variable 1) and genotype (Variable 2) and their interactions for all morphological and biochemical traits analysed.

\begin{tabular}{llll}
\hline Parameter & Treatment (VAR 1) & Species (VAR 2) & VAR1*VAR2 \\
\hline EC & 0.000 & 0.932 & 0.785 \\
Root length & 0.871 & 0.000 & 0.004 \\
Root FW & 0.002 & 0.001 & 0.012 \\
Root WC & 0.493 & 0.557 & 0.309 \\
Stem diameter & 0.082 & 0.057 & 0.027 \\
Stem length & 0.404 & 0.000 & 0.017 \\
Stem FW & 0.000 & 0.000 & 0.033 \\
Stem WC & 0.063 & 0.000 & 0.763 \\
Leaves no. & 0.000 & 0.000 & 0.763 \\
Leaf FW & 0.000 & 0.000 & 0.000 \\
Leaf WC & 0.044 & 0.232 & 0.632 \\
Total FW & 0.000 & 0.000 & 0.000 \\
Chla & 0.647 & 0.000 & 0.715 \\
Chlb & 0.785 & 0.989 & 0.008 \\
\hline
\end{tabular}




\begin{tabular}{llll}
\hline Caro & 0.014 & 0.000 & 0.000 \\
Pro & 0.000 & 0.000 & 0.002 \\
$\mathrm{Na}^{+}$ & 0.000 & 0.000 & 0.010 \\
$\mathrm{~K}+$ & 0.000 & 0.002 & 0.010 \\
$\mathrm{Cl}^{-}$ & 0.000 & 0.003 & 0.606 \\
$\mathrm{~K} / \mathrm{Na}$ & 0.000 & 0.000 & 0.009 \\
$\mathrm{TSS}$ & 0.539 & 0.000 & 0.041 \\
\hline
\end{tabular}

\section{Photosynthetic pigments}

A common effect of salt stress is the degradation of photosynthetic pigments (chlorophyll a and b, and carotenoids). In the lima bean cultivars analysed here, there were only small, non-significant variations of chlorophylls levels. Total carotenoids contents were significantly reduced only in cultivar VPH-79 and even increased in BGV 15888 (Table 5). Regarding variations between cultivars, they were significant for chlorophyll and carotenoids (

Table 4).

Table 5. Effect of salinity on photosynthetic pigments (Chla, chlorophyll a; Chlb, chlorophyll b; Caro, carotenoids) contents of plants of the four Phaseolus lunatus cultivars. Means followed by SE $(n=5)$. Different letters indicate significant differences withing each cultivar according to the Tukey's test $(\alpha=0.05)$

\begin{tabular}{clllll}
\hline $\begin{array}{c}\text { Pigment } \\
\left(\mathbf{m g ~ g}^{-1} \mathbf{~ D W}\right)\end{array}$ & $\begin{array}{c}\text { Treatment } \\
(\mathbf{m M}\end{array}$ & VPH-79 & BGV-12848 & $\begin{array}{c}\text { BGV- } \\
\mathbf{1 5 4 1 0}\end{array}$ & BGV 1588 \\
\hline & 0 & $6.33 \pm 0.07 \mathrm{a}$ & $6.24 \pm 0.77 \mathrm{a}$ & $5.14 \pm 0.44 \mathrm{a}$ & $4.17 \pm 0.66 \mathrm{a}$ \\
$\mathrm{Nhl} \mathrm{a}$ & 50 & $5.60 \pm 0.44 \mathrm{a}$ & $5.71 \pm 0.85 \mathrm{a}$ & $6.05 \pm 0.37 \mathrm{a}$ & $3.81 \pm 0.27 \mathrm{a}$ \\
& 100 & $5.41 \pm 0.97 \mathrm{a}$ & $6.50 \pm 0.98 \mathrm{a}$ & $5.84 \pm 1.02 \mathrm{a}$ & $3.03 \pm 0.85 \mathrm{a}$ \\
& 150 & $5.25 \pm 0.28 \mathrm{a}$ & $6.02 \pm 0.65 \mathrm{a}$ & $5.25 \pm 0.28 \mathrm{a}$ & $3.89 \pm 0.88 \mathrm{a}$ \\
& 0 & $3.17 \pm 0.49 \mathrm{a}$ & $2.37 \pm 0.26 \mathrm{a}$ & $2.80 \pm 0.22 \mathrm{a}$ & $2.22 \pm 0.07 \mathrm{a}$ \\
$\mathrm{Chl} \mathrm{b}$ & 50 & $2.35 \pm 0.26 \mathrm{a}$ & $2.14 \pm 0.39 \mathrm{a}$ & $2.43 \pm 0.41 \mathrm{a}$ & $2.38 \pm 0.11 \mathrm{a}$ \\
& 100 & $1.89 \pm 0.39 \mathrm{a}$ & $2.32 \pm 0.18 \mathrm{a}$ & $2.44 \pm 0.78 \mathrm{a}$ & $2.77 \pm 0.80 \mathrm{a}$ \\
& 150 & $1.58 \pm 0.13 \mathrm{a}$ & $2.13 \pm 0.14 \mathrm{a}$ & $1.93 \pm 0.69 \mathrm{a}$ & $2.02 \pm 0.38 \mathrm{a}$ \\
& 0 & $2.69 \pm 1.04 \mathrm{~b}$ & $0.67 \pm 0.09 \mathrm{a}$ & $0.49 \pm 0.04 \mathrm{a}$ & $0.54 \pm 0.15 \mathrm{a}$ \\
Caro & 50 & $0.97 \pm 0.25 \mathrm{a}$ & $0.91 \pm 0.16 \mathrm{a}$ & $0.73 \pm 0.14 \mathrm{a}$ & $0.63 \pm 0.21 \mathrm{ab}$ \\
& 100 & $1.26 \pm 0.13 \mathrm{a}$ & $0.90 \pm 0.14 \mathrm{a}$ & $0.62 \pm 0.22 \mathrm{a}$ & $0.84 \pm 0.17 \mathrm{ab}$ \\
& 150 & $1.48 \pm 0.16 \mathrm{ab}$ & $1.29 \pm 0.14 \mathrm{a}$ & $1.08 \pm 0.24 \mathrm{a}$ & $1.32 \pm 0.11 \mathrm{~b}$ \\
\hline
\end{tabular}




\section{Ionic accumulation}

Leaf contents of sodium $\left(\mathrm{Na}^{+}\right)$and chloride $(\mathrm{Cl}-)$ increased in the four cultivars in parallel with increasing external salinity (Fig. 4 A). Maximum absolute concentrations of both ions were therefore registered in the presence of $150 \mathrm{~mm} \mathrm{NaCl}$. The relative increases with respect to the corresponding controls, grown in the absence of salt, varied between 3 and 5 -fold for $\mathrm{Na}^{+}$and between 5 and 7 -fold for $\mathrm{Cl}^{-}$, approximately. Interestingly, $\mathrm{K}+$ contents did not vary significantly in the most salt-tolerant cultivar, BGV-15410, whereas they increased in the leaves of salt-treated plants; it should be mentioned that, in the absence of external $\mathrm{NaCl}, \mathrm{K}^{+}$concentration was higher in $\mathrm{BGV}-$ 15410 and BGV-1588, the most tolerant cultivars, than in the most salt-sensitive, $\mathrm{VPH}-79$ and $\mathrm{BGV}-12848$ ( Fig. 4 C). The combined variation in $\mathrm{Na}^{+}$and $\mathrm{K}^{+}$contents resulted in a reduction in $\mathrm{K}^{+} / \mathrm{Na}^{+}$ratios in two cultivars, $\mathrm{BGV}-12848$ and $\mathrm{BGV}-1588$, and no changes in the remaining two (Fig. 4 D).

Fig. 4. Leaf monovalent ions contents ( $\mu \mathrm{mol} \mathrm{g}-1 \mathrm{DW}$ ) and $\mathrm{K}^{+} / \mathrm{Na}^{+}$ratios in plants of the four Phaseolus lunatus cultivars, grown for three weeks in the presence of the indicated $\mathrm{NaCl}$ concentrations.

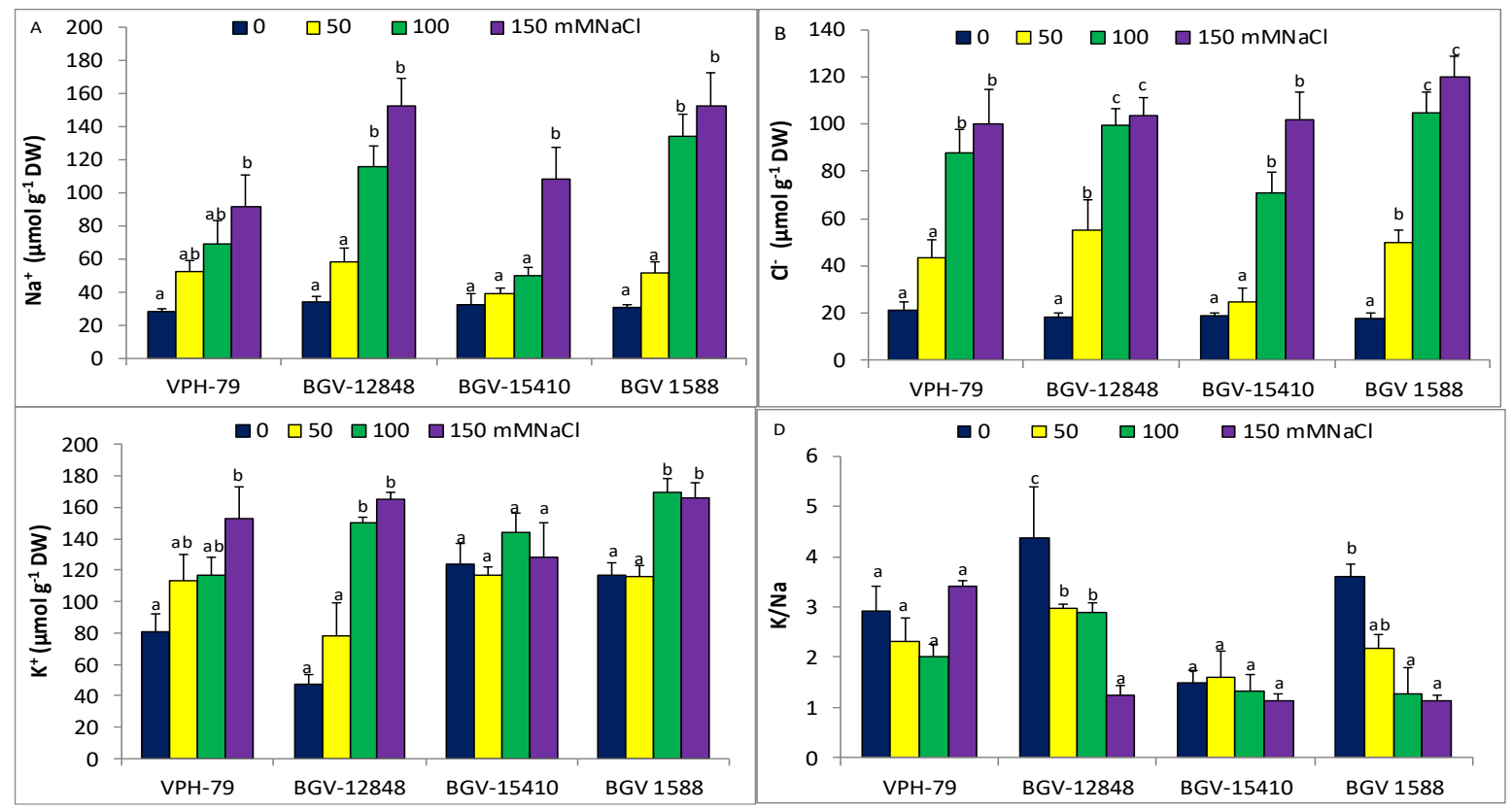

Note: Means followed by SE $(n=5)$. Different letters indicate significant differences within each cultivar according to the Tukey`s $(\alpha=0.05)$. 


\section{Osmolytes accumulation}

Cellular osmotic adjustment requires the synthesis and accumulation of compatible solutes or osmolytes under conditions that generate osmotic stress, as it is the case for the salt treatments. Leaf proline (Pro) levels increased in response to increasing external $\mathrm{NaCl}$, in a concentration-dependent manner (Fig. 5 A). Pro concentrations were highest in plants of the two most salt-tolerant cultivars (BGV1540 and BGV-1588), both in the controls and in the stressed plants (Fig. 5 A). Total soluble sugars (TSS) contents differed in the selected P. lunatus cultivars but did not vary significantly in any of them in response to the stress treatment (Figure Fig. 5B and

Table 4).

Fig. 5. Leaf osmolyte contents in plants of the four Phaseolus lunatus cultivars, grown for three weeks in the presence of the indicated $\mathrm{NaCl}$ concentration.

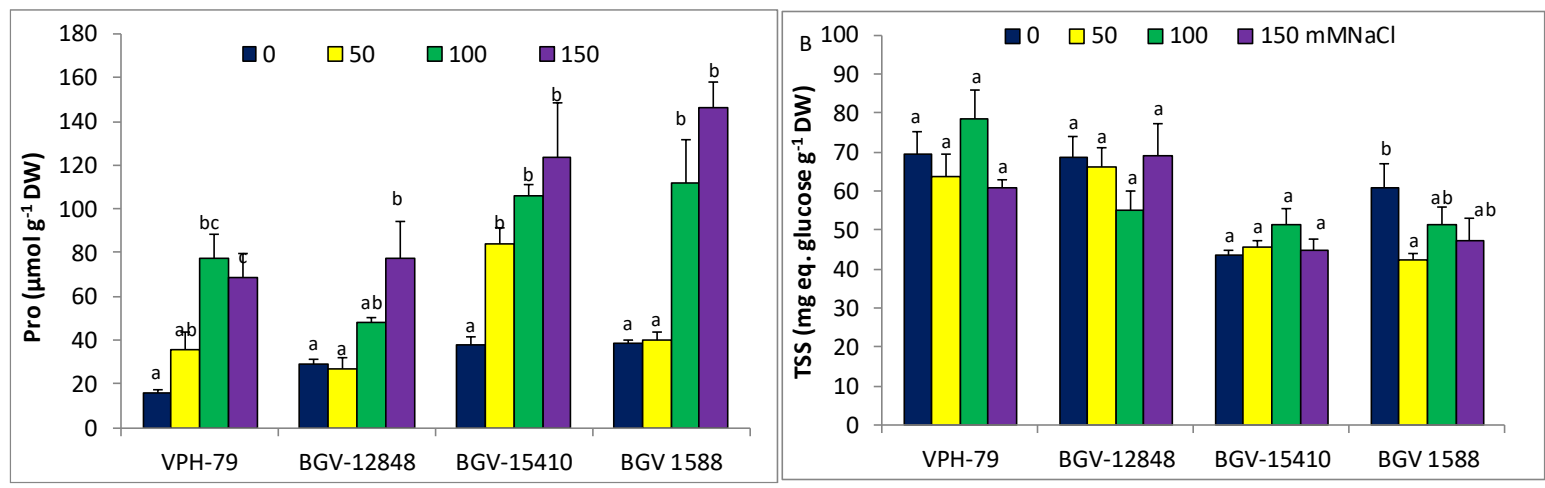

Note: Proline (Pro) (A) and total soluble sugar (TSS) levels (B). Means followed by SE $(n=5)$. Different letters indicate significant differences within each cultivar according to the Tukey`s test $(\alpha=0.05)$

\section{Principal component analysis (PCA)}

A PCA was performed including all measured parameters in the four analysed L. lunatus cultivars. The biplot of the two main components, which together explain $60 \%$ of the total variability, is shown in Fig. 6 . The electric conductivity of the substrate (i.e., salinity) is positively and strongly correlated with the concentrations 
of monovalent ions and proline, and negatively correlated with growth parameters, especially with leaf fresh weight, leaf water content or number of leaves, as well as with total fresh weight. Only in the absence of stress, and not for the salt treatments, a clear separation of the four cultivars can be observed in Fig. 6, where symbols corresponding to non-stressed controls are framed. Cultivars BGV-15410 and BGV1588 appear very close to each other, whereas VPH-79 is very distant from the other three due to its particular morphological features, as this cultivar has a considerably higher number of leaves, the longest stem, and the highest fresh weight.

Fig. 6. Principal Component Analysis (PCA).

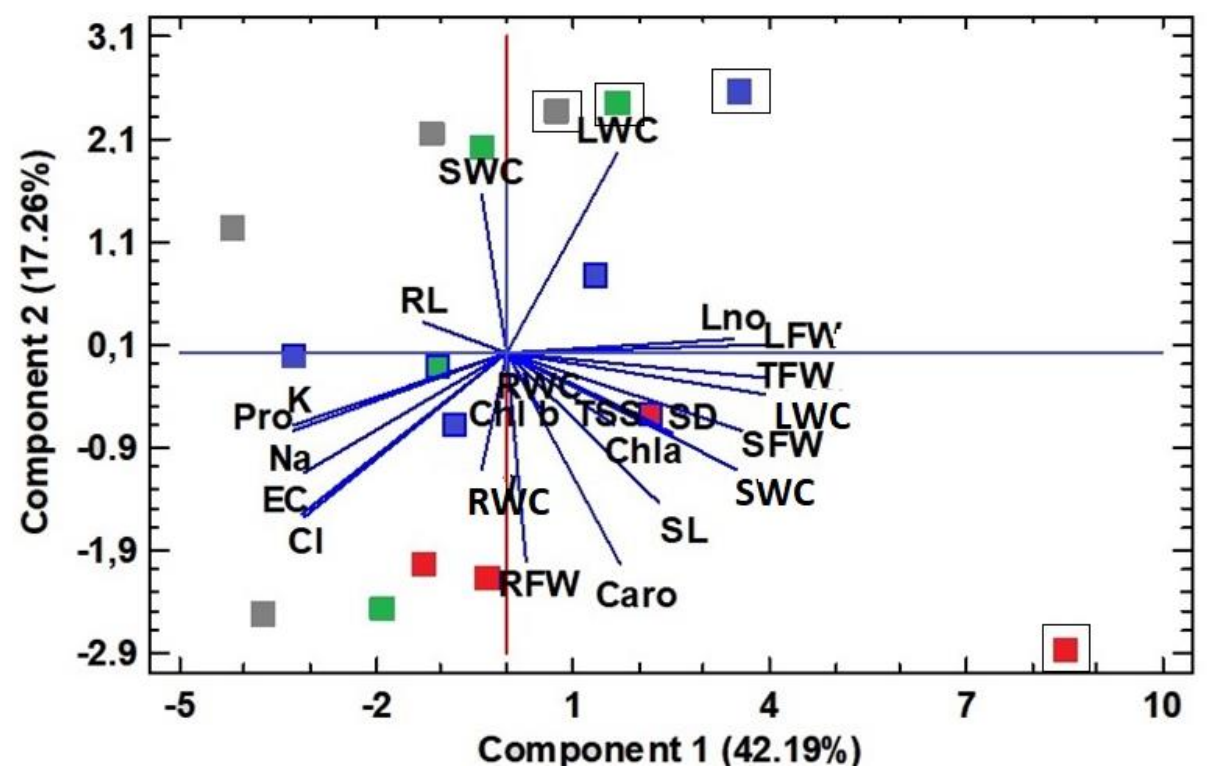

Note: Changes in growth parameters, photosynthetic pigments monovalent ions and osmolytes levels in plants growth under salt stress conditions for one month, with respect to the corresponding control, non-stressed plants of the four local cultivars of Phaseolus lunatus. : VPH-79 (red) BGV-12848 (blue), BGV-15410 (green), and BGV 158 (grey). Framed squares correspond to control treatments. Abbreviations: EC, substrate electric conductivity; RFW, root fresh weight, RWC, root water content; SD, stem diameter; SFW, stem fresh weight; SWC, stem water content; Lno, leaf numbers; LFW, leaf fresh weight, LWC, leaf water content; TFW, total fresh weight; Chla, chlorophyll a; Chla b, chlorophyll b; Caro, carotenoids; Na, sodium; K, potassium; Cl, chlorine; Pro, proline, TSS, total soluble sugars.

\subsubsection{Discussion}

The work presented here represents, to our knowledge, the first report on the effects of, and the responses to, salt stress in Phaseolus lunatus. The information gained from these experiments performed on four local Spanish lima bean cultivars 
may contribute to the development of efficient screening methods to select Phaseolus genotypes relatively tolerant to salinity for the benefit of breeders and farmers, and to help conserve genetic diversity in this crop.

Growth reduction is a general response in all glycophytes facing salt stress. Even among halophytes ('salt-loving' plants), only some extremely tolerant dicotyledonous succulent taxa have been reported to improve growth in the presence of low or moderate salt concentrations (Flowers and Colmer, 2008). A reduced growth rate allows the redirection of plant resources towards the defence against stress factors (Zhu, 2001). Quantitative assessment of growth inhibition under saline conditions is extremely reliable when ranking genotypes according to their relative degree of tolerance (Al Hassan et al., 2016). Of the four lima bean genotypes analysed in this study, cultivar BGV-15410 proved to be the most salt tolerant, whereas VPH-79 was the most sensitive to salt stress. The effects of salt stress were more clearly observed in the leaves of the plants, which showed significant reductions in their number and fresh weight. However, aside from BGV-12848, water content percentages in the tested plants did not decrease, indicating the presence of efficient mechanisms to avoid salt-induced dehydration, counteracting the osmotic stress generated by salinity; therefore, growth impairment probably resulted from the 'ion toxicity' component of salt stress.

In an attempt to pinpoint the mechanisms likely to be responsible for salt tolerance in this species, the concentrations of several biochemical markers associated with specific response pathways were determined in control and salt-stressed plants. A decrease in chlorophyll concentration has been observed in many legume species under high salinity conditions (Taffouo et al., 2010; Taibí et al., 2016); this is due to both the inhibition of enzymes associated with chlorophyll synthesis and the activation of the chlorophyllase responsible for its degradation (Soussi et al., 1998; Santos, 2004). However, no significant changes in chlorophylls concentrations were 
detected in any of the four $P$. Iunatus cultivars. On the other hand, carotenoids had a significant reduction in the most salt-sensitive $\mathrm{cV}$. VPH-79, but did not vary in BGV12848 and $B G V-15410$, and increased in BGV-1588. The absence of variation in the chlorophyll content does not implicitly mean salt tolerance, as other factors (not considered here) may result in the significant drop of leaf number and biomass observed in the most sensitive cultivars. Nevertheless, the lack of salt-induced chlorophyll degradation observed in our experiments probably contributes to a higher resistance to salinity of P. lunatus in comparison to other legume species. Salt resistance in several Phaseolus species, and also in different P. vulgaris cultivars, has been associated with $\mathrm{Na}+$ exclusion from the aerial part of the plants, as well as with the maintenance of steady $\mathrm{K}^{+}$concentrations in the leaves (Gil et al., 2014; Jacobi, 1964; Kramer et al., 1977; Seemann and Critchley, 1985; Bayuelo-Jiménez et al., 2012; Gama et al., 2007; Al Hassan et al., 2016). Potassium is considered to be one of the 'physiological' cations essential for plant metabolism, growth, and development (Gierth and Maser, 2007), whereas high $\mathrm{Na}+$ concentrations have harmful effects on non-halophytic plants, inhibiting many enzymatic activities and cellular processes (Rodriguez-Navarro and Rubio, 2006; Adams and Shin, 2014). Moreover, increased concentrations of $\mathrm{Na}^{+}$are generally associated with a reduction of $\mathrm{K}^{+}$, as both cations compete for the same binding sites, and $\mathrm{Na}+$ reduces $\mathrm{K}+$ uptake into the cell by using its membrane transport proteins. Many salt-tolerant plants can maintain high concentrations of $\mathrm{K}^{+}$when exposed to salinity, as has been described, for example, in Thellungiella halophila, a salt-tolerant relative of the glycophyte Arabidopsis thaliana (Volkov et al., 2003). Leaf $\mathrm{K}+$ concentrations were maintained or increased-especially at high external $\mathrm{NaCl}$ concentrations-in response to the salt treatments in the lima bean cultivars analysed here. Interestingly, $\mathrm{K}+$ concentrations in non-stressed plants were higher in BGV-15410 and BGV-1588, the two most salt tolerant cultivars. Higher $\mathrm{K}^{+}$contents in the absence of salt may represent an innate 
defence mechanism, which could enable these two cultivars to better adjust to saline conditions. Ensuring high concentrations of $\mathrm{K}^{+}$in leaves of salt-stressed plants can be considered as a basic, general mechanism of tolerance in lima beans. These data are in agreement with the essential role of $\mathrm{K}^{+}$in the responses of plants to salinity (and to other biotic and abiotic stresses), reiterating the necessity to optimise $\mathrm{K}^{+}$ fertilisation to avoid its deficiency in the soil (Wang et al., 2013) when cultivating lima beans, as for many other crops.

The biochemical parameter that clearly separated the four studied cultivars was the concentration of proline measured in leaves at the end of the salt treatments. Proline is a common osmolyte in plants, which accumulates not only under conditions of salt stress, but also in response to other abiotic stresses such as drought, extreme temperatures, nutritional deficiencies, presence of heavy metals, air pollution, or high UV radiation and, in some cases, to pathogen infection in plants (Hare and Cress, 1997; Saradhi et al., 1995; Siripornadulsil et al., 2002). Besides its key role in cellular osmotic adjustment under stress, it is also involved in the stabilisation of macromolecular structures, such as membranes and proteins (Siripornadulsil et al., 2002), and in free radical scavenging (Verbruggen and Hermans, 2008; Smirnoff and Cumbes, 1989). In our study, BGV-1540 and BGV-1588, the two cultivars that showed the highest salt tolerance (considering the relative degree of growth inhibition), recorded significantly higher leaf concentrations of Pro in comparison to the other two cultivars, both under salt stress and in control conditions.

There is no clear correlation between Pro concentrations and stress tolerance in species of the genus Phaseolus. In common beans, some reports detected higher Pro concentrations in the most tolerant cultivars (Cardenas-Avila et al., 2006), whereas in others the highest levels were found in the most sensitive cultivars (JiménezBremont et al., 2006). Al Hassan et al. (Al Hassan et al., 2016) measured lower Pro concentrations in the most tolerant $P$. vulgaris cultivars analysed, but total Pro 
concentrations were well below those determined in P. lunatus in the present work. Proline appears to play an important role in osmotic adjustment in lima beans, and the higher Pro concentrations present in the two most salt-tolerant cultivars most likely are responsible, at least partially, for this tolerance.

\section{Conclusions}

In conclusion, the data presented here showed that, during vegetative growth, some cultivars of $P$. lunatus could tolerate three weeks of exposure to salinities as high as $150 \mathrm{mM} \mathrm{NaCl}$, in agreement with previous reports indicating that this crop could be moderately salt-tolerant. However, these studies must be extended to longer saline treatments during a complete life cycle, including the assessment of the effects of salinity on agronomic traits, such as crop yield and quality, before concluding on the salt tolerance of lima bean cultivars. In any case, our results provide information on the basic mechanisms contributing significantly to salinity tolerance in this species, which include the maintenance, or increase, of $\mathrm{K}+$ concentrations and the accumulation of Pro in leaves, in response to the salt stress treatment. These mechanisms appear to be, in part, innate, as relatively higher $\mathrm{K}+$ and Pro levels have been measured in the most tolerant cultivars also in the absence of stress. Therefore, determination of leaf concentrations of Pro and $\mathrm{K}+$ may represent a rapid and simple strategy to screen large numbers of lima bean cultivars in order to pre-select those genotypes with a higher probability to be more salt tolerant.

Author Contributions: Conceptualization: O.V. and M.B.; methodology: S.A., W.M.C.B, J.V.L., and L.Y.; software: M.A.H.; validation: M.B., M.A.H., and O.V.; formal analysis: J.V.L.; investigation: S.A.; resources: O.V.; data curation: S.A.; writing-original draft preparation: M.B.; writing-review and editing: M.A.H. and O.V.; visualization: M.B.; supervision: O.V.; project administration: O.V.; funding acquisition: O.V. Funding: This research received no external funding. Conflicts of Interest: The authors declare no conflict of interest. 


\section{References}

Adams E., Shin R. (2014). Transport, signaling, and homeostasis of potassium and sodium in plants. J Integr Plant Biol., 56:231-249. doi: 10.1111/jipb.12159 PMID: 24393374

Al Hassan, M., Pacurar A., López-Gresa M.P., Donat-Torres M.P., Llinares J.V., Boscaiu M., Vicente O. (2016). Effects of salt stress on three ecologically distinct Plantago species. PLOS ONE, 11, e0160236, DOI: 10.1371 /journal.pone.0160236.

Al Hassan M., Morosan M., López-Gresa M.P., Prohens J., Vicente O., Boscaiu M. (2016). Salinity-induced variation in biochemical markers provides insight into the mechanisms of salt tolerance in common (Phaseolus vulgaris) and runner (P. coccineus) beans. Int. J. Mol. Sci., 17, 1582, DOI:10.3390/ijms 17091582.

Ashraf M., Foolad M.R. (2007). Roles of glycine betaine and proline in improving plant abiotic stress resistance. Environ. Exp. Bot., 59, 206-216, https://doi.org/10.1016/j.envexpbot.2005.12.006.

Baudoin J.P. (2006). Phaseolus Iunatus L. In Protabase, Brink, M., Belay, G., Eds.; PROTA (Plant Resources of Tropical Africa / Ressources végétales de l'Afrique tropicale), Wageningen, Netherlands.

Bates LS., Waldren R.P., Teare I.D. (1973). Rapid determination of free proline for water stress studies. Plant Soil, 39, 205-207.

Bayuelo-Jiménez J.S., Debouck D.G., Lynch J.P. (2002). Salinity Tolerance in Phaseolus species during early vegetative growth. Crop Sci., 42, 2184-2192, DOI:10.2135/cropsci2002.2184.

Bayuelo-Jiménez J.S., Jasso-Plata N., Ochoa I. (2012). Growth anphysiological responses of Phaseolus species to salinity stress. Int. J. Agron., 80, 207-222.

Cárdenas-Avila M.L., Verde-Star J., Maiti R.K., Foroughbakhch P.R., GámezGonzález H., Martínez-Lozano S., Núñez-González M.A., García-Díaz G., Hernández-Piñero J.L., Morales-Vallarta M.R. (2006). Variability in accumulation of free proline on in vitro calli of four bean (Phaseolus vulgaris L.) Cultivars exposed to salinity and induced moisture stress. Phyton, 75, 103108.

Casado S., Gonzáles J.M., Varela F., Rosselló J., Carrascosa M., Soriano J.J., Camarillo J.M. (2009). Estudio Diagnóstico sobre la Biodiversidad Cultivada y la Agricultura Ecológica; Sociedad Española de Agricultura Ecológica - Red de Semillas "Resembrando e Intercambiando": Seville, Spain.

De Ron A.M., Santalla M., Rodiño A.P., González A.M., Godoy L., Mansilla J.P., BlairM. (2016). Judia. En Las variedades locales en la mejora genética de plantas; Ruiz de Galarreta, J.I., Prohens, J., Tierno, R, Eds.; Servicio Central de Publicaciones del Gobierno Vasco: Donostia-San Sebastián, pp. 155-170, ISBN 978-84-4573395-0. 
Dubois M., Gilles K.A., Hamilton J.K., Reberd P.A., Smith F. (1956). Colorimetric method for determination of sugars and related substances. Anal. Chem., 28, 350-356.

Fita A., Rodríguez-Burruezo A., Boscaiu M., Prohens J., Vicente O. (2015). Breeding and domesticating crops adapted to drought and salinity: A new paradigm for increasing food production. Front. Plant Sci., 12, DOI: $10.3389 / \mathrm{fpls} .2015 .00978$.

Flowers T.J., Colmer T.D. (2008). Salinity tolerance in halophytes, New Phytologist 179:945-963. DOI: 10.1111/j.1469-8137.2008.02531.x.

Gama P.B.S., Inanaga S., Tanaka K., Nakazawa R. (2007). Physiological response of common bean. (Phaseolus vulgaris L.) seedlings to salinity stress. Afr. J. Biotechnol., 6, 79-88.

Gierth M., Mäser P. (2007). Potassium transporters in plants- Involvement in K+ acquisition, redistribution and homeostasis. FEBS Lett., 581, 2348-2356.

Gil R., Bautista I., Boscaiu M., Lidón A., Wankhade S., Sánchez H., Linares J., Vicente O. (2014). Responses of five Mediterranean halophytes to seasonal changes in environmental conditions. AOB Plants, 6, plu049.

Grattan S., Grieve C.M. (1999). Salinity-mineral nutrient relations in horticultural crops. Sci. Hortic., 78, 127-157.

Gupta B., Huang B. (2014). Mechanism of salinity tolerance in plants: Physiological, biochemical, and molecular characterization. Int. J. Genomics, ID 701596, http:/ /dx.doi.org/10.1155/2014/701596.

Hare P.D., Cress W.A. (1997). Metabolic implications of stress induced proline accumulation in plants. Plant Growth Regul. 21, 79-102.

Hoagland D.R., Arnon D.I. (1950). The water-culture method for growing plants without soil. Circular. 2nd ed. University of California Agricultural Experiment Station, Berkeley.

IPCC. Intergovernmental panel on climate change," in Proceeding of the 5th Assessment Report, WGII, Climate Change 2014: Impacts, Adaptation, and Vulnerability (Cambridge: Cambridge University Press). Available at: http://www.ipcc.ch/report/ar5/wg2/ [accessed on July 15, 2018].

Jackson M., Ford-Lloyd B., Parry M. (2013). Plant Genetic Resources and Climate Change, Volume $4 \mathrm{CABI}$ Climate Change.

Jacobi B. (1964). Function of bean roots and stems in sodium retention. Plant Physiol., 39, 445-449.

Jiménez-Bremont J.F., Becerra-Flora A., Hernández-Lucero E., Rodríguez-Kessler M., Acosta-Gallegos J.A., Ramírez-Pimentel J.G. (2006). Proline accumulation in two bean cultivars under salt stress and the effect of polyamines and ornithine. Biol. Plant. 50, 763-766. 
Kramer D., Läuchli A., Yeo A.R., Gullasch J. (1977). Transfer cells in roots of Phaseolus coccineus: Ultrastructure and possible function in exclusion of sodium from the shoot. Ann. Bot., 41, 1031-1040.

Lichtenthaler H.K., Wellburn A.R. (1983). Determinations of total carotenoids and chlorophylls a and b of leaf extracts in different solvents. Biochem. Soc. Trans., $11,591-592$.

López-Alcocer J.J., Lépiz-Ildefonso R., González-Eguiarte D.R., Rodríguez-Macías R., López-Alcocer E. (2016). Morphological variability of wild Phaseolus lunatus from the western region of Mexico. Rev. Fitotec. Mex., 39, 49-58.

Martínez-Castillo J., Camacho-Pérez L., Villanueva-Viramontes S., Andueza-Noh R.H., Chacón-Sánchez M.I. (2014). Genetic structure within the Mesoamerican gene pool of wild Phaseolus lunatus (Fabaceae) from Mexico as revealed by microsatellite markers: implications for conservation and the domestication of the species. Am. J. Bot. 101, 851-864.

Munns R., Tester M. (2008). Mechanisms of salinity tolerance. Annual review of plant Biology, 59, 651-681.

Owens S. (2001). Salt of the earth. Genetic engineering may help to reclaim agricultural land lost due to salinisation. EMBO Rep., 2, 877-879, DOI: 10.1093 /embo-reports/kve219.

Parida A.K., Das A.B. (2005). Salt tolerance and salinity effects on plants: a review. Ecotoxicol. Environ. Saf., 60: 324-349, DOI: 10.1016/j.ecoenv.2004.06.010.

Rodrigues Do Nascimento M.G., Ursulino Alves E., Mauricio da Silva M.L., Marques Rodrigues C. (2017). Lima bean (Phaseolus lunatus L.) seeds exposed to different salt concentrations and temperatures. Rev. Caatinga, 30, 738-747, DOI:10.1590/1983-21252017v30n322rc

Rodriguez-Navarro A., Rubio F. (2006). High-affinity potassium and sodium transport systems in plants. J. Exp. Bot., 57, 1149-1160.

Santos C.V. (2004). Regulation of chlorophyll biosynthesis and degradation by salt stress in sunflower leaves. Sci. Hort., 103, 93-99.

Saradhi P., Alia P., Arora S., Prasad K.V. (1995). Proline accumulates in plants exposed to UV radiation and protects them against UV induced peroxidation. Biochem. Biophys. Res. Commun., 209, 1-5.

Seemann J.R., Critchley C. (1985). Effects of salt stress on the growth, ion content, stomatal behaviour and photosynthetic capacity of a salt-sensitive species, Phaseolus vulgaris L. Planta, 164, 151-162.

Siripornadulsil S., Train S., Verma D.P.S., Sayre R.T. (2002). Molecular mechanisms of proline mediated tolerance to toxic heavy metals in transgenic microalgae. Plant Cell., 14, 2837-2847.

Smirnoff N., Cumbes Q.J. (1989). Hydroxyl radical scavenging activity of compatible solutes. Phytochemistry, 28, 1057-1060. 
Soussi M., Ocana A., Lluch C. (1998). Effect of salt stress on growth, photosynthesis and nitrogen fixation in chickpea (Cicer arietinum L.). J. Exp. Bot., 49, 1329-1337.

Szabados L., Savouré A. (2010). Proline: A multifunctional amino acid. Trends Plant Sci., 15, 89-97, DOI: 10.1016/j.tplants.2009.11.009.

Taffouo V.D., Wamba O.F., Youmbi E., Nono G.V., Akoa A. (2010). Growth, yield, water status and ionic distributionresponse of three bambara groundnut (Vigna subterranea (L.) Verdc.) landraces grown under saline conditions. Int. J. Bot., 6, 53-58.

Taïbi, K., Taïbi, F.; Abderrahim L.A., Ennajah A., Belkhodja M., Mulet J.M. (2016). Effect of salt stress on growth, chlorophyll content, lipid peroxidation and antioxidant defense systems in Phaseolus vulgaris L. S. Afr. J. Bot., 105, 306-312. 10.1016/j.sajb.2016.03.011.

Verbruggen N., Hermans C. (2008). Proline accumulation in plants: A review. Amino Acids, 35, 753-759.

Volkov V. (2015). Salinity tolerance in plants. Quantitative approach to ion transport starting from halophytes and stepping to genetic and protein engineering for manipulating ion fluxes. Front. Plant Sci., 6, 873. pmid:26579140 doi: [10.3389/fpls.2015.00873].

Volkov V., Wang B., Dominy P.J., Fricke W., Amtmann A. (2003). Thellungiella halophila, a salt-tolerant relative of Arabidopsis thaliana, possesses effective mechanisms to discriminate between potassium and sodium. Plant Cell Environ., 27, 1-14.

Wang M., Zheng Q., Shen Q., Guo S. (2013). The critical role of potassium in plant stress response. Int. J. Mol. Sci., 14, 7370-7390.

Weimberg R. (1987). Solute adjustments in leaves of two species of wheat at two different stages of growth in response to salinity. Physiol Plant., 70, 381-388.

Zhu J.K. (2001). Plant salt tolerance. Trends Plant Sci., 6, 66-71. 
Subcapítulo 3.2. Morphological and Agronomic Characterization of Spanish Landraces of Phaseolus vulgaris $\mathrm{L}$.

Reference:

Arteaga Sugenith, Yabor Lourdes, Torres José, Solbes Eva, Muñoz Enrique, Díez María José, Vicente Óscar, Boscaiu Mónica. Agriculture 9(7): 149DOI: 10.3390/agriculture9070149 


\section{Morphological and Agronomic Characterization of Spanish Landraces of Phaseolus} vulgaris $\mathrm{L}$

Abstract: Beans (Phaseolus vulgaris L.) originated on the American continent, specifically in the Mesoamerican zone, and their domestication took place independently in the Mesoamerican area and the Andean zone, giving rise to two well-differentiated genetic pools. It was also noted that the Andean wild populations originated from only a few thousand individuals from the Mesoamerican wild populations, which produced a great bottleneck in the formation of the Andean population. During centuries of cultivation in the Iberian Peninsula after its introduction in the 16th century, beans adapted to new environments, evolving numerous local landraces. Twenty-four local landraces of P. vulgaris from Spain were analyzed in the greenhouse during two consecutive seasons. From each genotype, five plants were grown and characterized for 17 quantitative and 15 qualitative traits using the International Board for Plant Genetic Resources (IBPGR) descriptors. Data were analyzed statistically by analysis of variance (ANOVA), principal component analysis (PCA), and cluster analysis. The results obtained indicate a high variability for most traits, especially those related to the yield and its components. The PCA and cluster analysis separated the landraces according to the color of the seed, the yield, and the pod and seed traits related to yield. Numerous traits exhibited interactions between the genotype and the environment. Most accessions reached higher yields in spring, in which solar radiation favors photosynthesis and, consequently, photoassimilation. The different response to the changing environment of the set of accessions studied in the present work is of great interest, and it can be exploited in breeding cultivars adapted to a broader range of environmental conditions. Keywords: common bean; local landraces; germplasms bank; variability 


\subsubsection{Introduction}

Common bean (Phaseolus vulgaris L.) is one of the most important legume crops. The world production of beans in 2017 was 57,496,465 tons, cultivated on $38,229,984$ hectares. Asia is the continent with the highest production at $38,045,186$ tons, and Europe is the continent with the lowest production at 2,305,846 tons. In the European Union, the countries with the highest production are France, Lithuania, and Spain with $370,050,230,112$, and 183,324 tons, respectively. Castilla y León is the community with the largest area and production of beans in Spain, followed by Galicia and Asturias (FAO, 2019).

According to archeological, botanic, historical, and linguistic data, Gepts and Debouck (Gepts and Debouck, 1991) deduced that the common bean originated in the area between northern Mexico and northeastern Argentina. Due to the wide distribution of its wild ancestor through Mesoamerica and South America, the species was domesticated in two separate areas, the Mesoamerican and the South Andean. This resulted in two different gene pools based on differences in the phaseolin seed protein (Gepts, 1990), molecular markers (Koening and Gepts, 1989; Tohrme et al., 1996; Beebe et al., 2000; Duran et al., 2005), and morphological traits (Gepts and Debouck, 1991; Singh et al., 1991). The Mesoamerican gene pool extends from Mexico through Central America to northern Colombia, whereas the Andean one covers Peru, Chile, Bolivia, and northern Argentina. However, more recently, Bitochi et al. (2012) conducted a study to solve the ongoing debate on the origins of the common bean, by investigating the nucleotide diversity at five gene loci of a large sample that represents the entire geographical distribution of the wild forms of this species. Their results clearly indicate a Mesoamerican origin of the common bean and the occurrence of a bottleneck during the formation of the Andean gene pool.

The first varieties of $P$. vulgaris, corresponding to small-grain Mesoamerican genotypes, were introduced in Spain and Portugal around 1506 (Ortwin-Sauer, 1966) 
and from South America around 1532 (Brucher and Brucher, 1976; Debouck, 1995). Later on, gradually, Andean genotypes of large grain were also introduced as new territories were explored in the New World (Brucher and Brucher, 1976; Debouck, 1995). This germplasm spread throughout the Spanish territory and adapted to new environments, in terms of temperature and cropping systems, especially in the north and northwest of the Iberian Peninsula, which is the area where the greatest genetic variability was found (Santalla et al., 2002). On the other hand, the cultivation of germplasm of both genetic stocks occurred in proximal areas, in small farms, which favored the genetic flow between them, contrary to the genetic isolation that existed in America. This led to recombination between both genetic stocks, resulting in new genetically intermediate forms with both Mesoamerican and Andean phenotypes. The Iberian Peninsula can be considered as a secondary center of diversification of this species since beans were cultivated here for centuries in different agrosystems (Pinheiro et al., 2007). Although commercial varieties largely displaced landraces, there are still farmers who grow them for self-consumption and sale in local markets, especially in the north and northwest of Spain, where there is a marked tradition of this crop.

A huge number of accessions of this crop were collected and conserved in germplasm banks, and its genetic diversity was assessed in many different studies. Some of the most important collections are stored at the Center for Tropical Agriculture (CIAT, Cali, Colombia), the Western Regional Plant Introduction Station, Pullman (Washington, USA), Institut für Pflanzengenetik und Kulturpflanzenforschung (IPK, Gatersleban, Germany), and the Vavilov Institute of Plant Industry (VIR, Russian Federation) (Lioi and Piergiovanni, 2013). In Spain, there are several institutions conserving accessions of the genus Phaseolus. The most important one is maintained in the Spanish Center for Genetic Resources, (CRF, Alcalá de Henares, Madrid), followed by the Biological Mission of Galicia (MBG, Pontevedra), the Agricultural 
Technology Institute of Castilla y León (ITACyL, Valladolid), the Agrifood Research and Technology Center of Aragon (CITA, Zaragoza), and the Institute of Conservation and Improvement of the Valencian Agrodiversity (COMAV, Polytechnic University of Valencia).

Average yields of common beans, as for practically all major crops, are much below $20-50 \%$ of their record yields, mostly due to abiotic stress factors, such as drought, soil salinization, or extreme temperatures, among others (Boyer, 1982). The forecasted effects of global warming are mostly longer and more frequent periods of drought, heat waves, and irregular meteorological patterns. They are already noticed in large areas of the world, including the Mediterranean (Cramer et al., 2018). These factors, in combination with the shortage of water available for irrigation, will probably increase the losses in agricultural production. Commercial varieties, generally selected on criteria related to their yields or tolerance to pests and parasites, are generally sensitive to abiotic stress. One of the challenges of modern agriculture is the use of genotypes more tolerant to drought and salinity; therefore, the screening of neglected varieties and local landraces stored in germplasm banks acquires a special relevance (Fita et al., 2015). Phenotyping common beans for adaptation to abiotic stress, and analysis of its physiological mechanisms of response to stress were the object of numerous studies in the last decade (Santos et al., 2009; Rosales et al., 2012; Beebe et al., 2013), among many others. Similar comparative studies were performed by our group on different species of Phaseolus (Al Hassan et al., 2016; Morosan et al., 2017; Arteaga et al., 2018). In this work, we present an exhaustive morphological characterization of 24 accessions of common bean local landraces stored at the seed bank of COMAV; they were chosen, maximizing their geographical origin and their morphological diversity, for studying their adaptation to drought and salinity (manuscript in preparation). The study of the phenotypic traits is essential to know the agronomic potential of these landraces and their use in plant 
breeding. The high variability found for morphological and agronomic traits in the different types of bean studied is remarkable and makes this set of accessions of great interest for their use in breeding.

\subsubsection{Materials and Methods}

\section{Seed Material}

Twenty-four local landraces of $P$. vulgaris from Spain were characterized for two consecutive growing seasons, in autumn and spring. Accessions were collected in the 1990 s directly from growers. The origin of the analyzed accessions with their reference codes is indicated in Fig. 7.

Six seeds of each genotype were germinated in individual pots of 1.6 L. Once plants formed the first three trifoliate true leaves and reached a minimum of $20 \mathrm{~cm}$ in height, they were transplanted to pots of $7 \mathrm{~L}$ on a substrate with peat-perlite-vermiculite $(2: 1: 1)$ in the greenhouse. The experimental design included five individuals from each accession in one plot, with sufficient separation between them. Watering was carried out by drip irrigation with Hoagland solution provided by the greenhouse. The average temperature during the trial carried out in autumn was $20.3^{\circ} \mathrm{C}$ (ranging from 15.9 to $24.1{ }^{\circ} \mathrm{C}$ ), the relative humidity was $86.85 \%$, and the solar radiation was 38.4 $\mathrm{W} \cdot \mathrm{m}^{2}$. In spring, the average temperature was $20.4{ }^{\circ} \mathrm{C}\left(15.3-24.1{ }^{\circ} \mathrm{C}\right)$, relative humidity was $84.41 \%$, and radiation $85.5 \mathrm{~W} \bullet \mathrm{m}^{2}($

\section{Descriptors Used for the Agronomic Characterization}

During the two cycles of growth, 17 quantitative and 15 qualitative traits related to vegetative characteristics, flowers, pods, and seeds were recorded (Table 6). The descriptors developed by the International Board for Plant Genetic Resources (IBPGR) were used (IBPGR, 1982). This descriptor list was prepared by IBPGR in a standard format following the advice of crop experts throughout the world. Five plants, and 
five pods and ten seeds from each plant were analyzed for each genotype in each cycle. Pods were collected when they were completely ripe. Productivity was calculated by multiplying the number of pods per plant by the number of seeds per pod and by the average weight of one seed.

Fig. 8)

Fig. 7. Geographic origin of the 24 Phaseolus vulgaris cultivars.

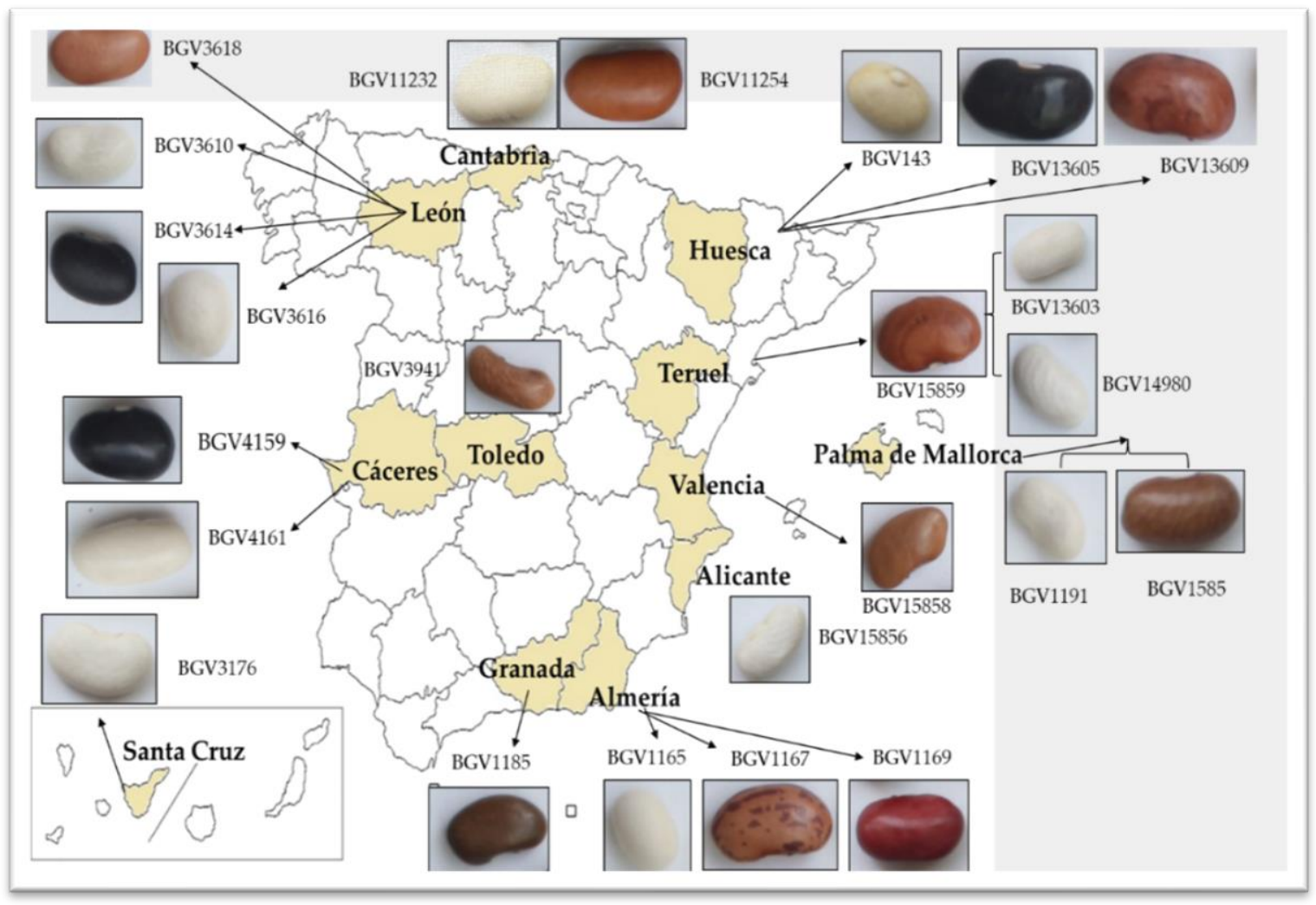




\section{Descriptors Used for the Agronomic Characterization}

During the two cycles of growth, 17 quantitative and 15 qualitative traits related to vegetative characteristics, flowers, pods, and seeds were recorded (Table 6). The descriptors developed by the International Board for Plant Genetic Resources (IBPGR) were used (IBPGR, 1982). This descriptor list was prepared by IBPGR in a standard format following the advice of crop experts throughout the world. Five plants, and five pods and ten seeds from each plant were analyzed for each genotype in each cycle. Pods were collected when they were completely ripe. Productivity was calculated by multiplying the number of pods per plant by the number of seeds per pod and by the average weight of one seed.

Fig. 8. Solar radiation registered in the greenhouse during the autumn (a) and spring trials (b)

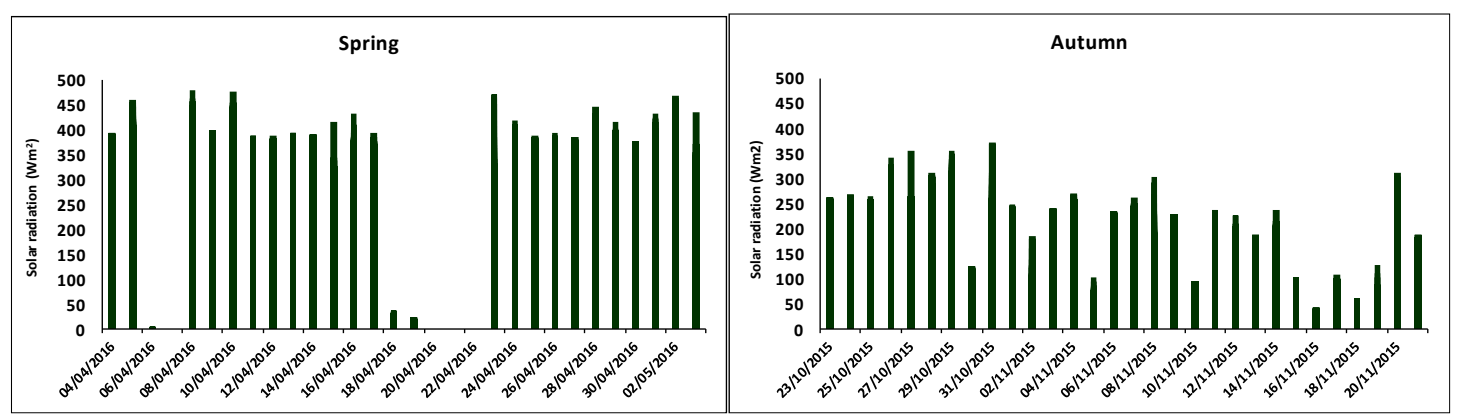

Table 6. Quantitative and qualitative traits in the 24 Phaseolus vulgaris accessions. IBPGRInternational Board for Plant Genetic Resources.

\begin{tabular}{|c|c|c|}
\hline Descriptor (IBPGR) & Acronym & Unit/scores \\
\hline \multicolumn{3}{|c|}{ Quantitative } \\
\hline \multicolumn{3}{|c|}{ Vegetative } \\
\hline 4.1.1. Leaflet length & LeafL & $\begin{array}{l}\text { Measured on terminal leaflet of third trifoliate leaf } \\
\text { from pulvinus to leaf tip. }\end{array}$ \\
\hline Width of the central sheet $(\mathrm{cm})^{* * *}$ & Wcshe & $\begin{array}{l}\text { Measured on the terminal leaflet of the third } \\
\text { trifoliate leaf }(\mathrm{cm})\end{array}$ \\
\hline
\end{tabular}




\begin{tabular}{|c|c|c|}
\hline 6.1.1. Hypocotyl length & HypL & $\begin{array}{l}\text { Average length in } \mathrm{cm} \text { from } 5 \text { plants measured } \\
\text { when primary leaves fully expanded. }\end{array}$ \\
\hline 6.1.9. Plant height & PlantH & $\begin{array}{l}\text { Average, in } \mathrm{cm} \text {, at maturity from } 5 \text { plants } \\
\text { measured from cotyledon scar to tip of plant }\end{array}$ \\
\hline 6.1.10. Stem diameter & StemD & $\begin{array}{l}\text { Measured in } \mathrm{mm} \text { at maturity for plants at crop } \\
\text { density. }\end{array}$ \\
\hline
\end{tabular}

4.2.2. Days to flowering

4.2.3 Flower buds per inflorescence

4.2.7. Pod length

6.2.9. Inflorescence length

6.2.10. Pedicel length

6.2.18. Pods per plant

Days to harvest***

Seed

6.3.1. Seeds per pod

6.3.3. Seed weight

6.3.5.1. Length

6.3.5.2. Width

6.3.5.3. Height

Plant type ** $^{* *}$

Inflorescence and Pod

4.2.6. Pod colour (from fully expanded immature pod)

4.2.8. Pod cross-section

Pcross

4.2.9. Pod curvature (of fully expanded immature pod

PedL

Dharv

SeedP
Number of days from emergence to stage where $50 \%$ of plants have set flowers.

Average number of flower buds from 5 plants examining one inflorescence from each plant.

Average length in $\mathrm{cm}$ of the largest fully expanded immature pods.

InfloL Average, in $\mathrm{cm}$, from 5 plants

Average, in $\mathrm{cm}$, of older flower from 5 plants examining one inflorescence from each plant.

PPlant Average from 5 plants at crop density.

Time period between seed sowing and mature pods sampling

Average number of seeds from one pod selected from 5 plants.

SeedWh Weight of 100 seeds in grams

SeedL Measured parallel to the hilum (mm)

SeedW $\quad$ Mm

SeedH Height, Measured from hilum to opposite side

\section{Qualitative}

\section{Vegetative}

I. determinate bush, II. indeterminate straight, III. Planty indeterminate crawling, IV. indeterminate climbing.

Dark purple (1), Carmine red (2), Purple stripe on Green (3), Carmine tripe on Green (4), Pale red stripe on Green (5), Dark pink (6), Normal Green (7), Shiny green (8), Dull green to silver grey (9), Golden or yellow (10), Pale yellow to white (11), Other (12)

Very flat (1), Pear shaped (2), Round elliptic (3), Figure of eight (4), Other.

Straight (3), Slightly curved (5), Curved (7), Recurving (9) 


\begin{tabular}{|c|c|c|}
\hline 4.2.10. Pod suture string & (Psuts) & $\begin{array}{l}\text { Stringless }(0) \text {, few strings ( } 3) \text {, moderately stringy } \\
(5) \text {, very stringy ( } 7)\end{array}$ \\
\hline $\begin{array}{l}\text { 4.2.11. Pod color at physiological } \\
\text { maturity }\end{array}$ & (Pcmat) & $\begin{array}{l}\text { Dark purple (1), red (2), pink (3), yellow (4), pale } \\
\text { yellow with colored mottling or stripes (5), } \\
\text { persistent white (6) }\end{array}$ \\
\hline 6.2.12. Position of pods & PosP & $\begin{array}{l}\text { Base (1), Centre (2), Top (3), Combination of 1, 2, } \\
\text { and } 3(4) \text {, Other (5) }\end{array}$ \\
\hline 6.2.15. Pod beak position & Pbeakp & Marginal (1), Non marginal (2) \\
\hline 6.2.16. Pod beak orientation & Pbeako & Upward (3), Straight (5), Downward (7) \\
\hline 6.2.17. Dry pod colour & Dpcol & $\begin{array}{l}\text { Dark purple (1), Carmine red (2), Purple stripe on } \\
\text { green (3), Carmine stripe on green (4), Pale red } \\
\text { stripe on green (5), Dark pink (6), Normal green } \\
\text { (7), Shiny green (8), Dull green to silver grey (9), } \\
\text { Golden or deep yellow (10), Pale yellow to white } \\
\text { (11), Other (12) }\end{array}$ \\
\hline
\end{tabular}

Seed

4.3.1. Seed coat patterns Scoatp

Absent (0), Constant mottled (1), Striped (2), Rhomboid spotted (3), Speckled (4), Circular mottling (5), Marginal colour pattern (6), Broad striped (7), Bicolor (8), Spotted bicolor (9), Pattern around hilum (10), Other (11).

Black (1), Brown, pale to dark (2), IMaroon (3), Grey, brownish to greenish (4), Yellow to greenish

4.3.2. Seed coat colour Scoatdc yellow (5), Pale-cream to buff (6), Pure white (7), Whitish (8), White, purple tinged (9), Chlorophyll green (10). Green to olive (11), Red (12), Pink (13), Purple (14), Other (15).

4.3.4. Brilliance of seed BSeed Matt (3), Medium (5), Shiny (7) Round (1), Oval (2), Cuboid (3), Kidney shaped (4), 4.3.5. Seed shape SHseed Kidney pronunciated (5), Truncate fasgiate (6). Figure 4 6.3.2. Apparent seed veining Aseed Absent (0), Present (1) ** Singh (Singh, 1982) *** Rodrigo ((Rodrigo-Miguez, 2000).

\section{Data Analysis}

A two-way analysis of variance (ANOVA) was performed for all quantitative traits to check the interaction between the genotype and the environment. Quantitative traits were summarized as mean, standard deviation, coefficient of variation, and minimum and maximum values. The qualitative characteristics were expressed on scales, as shown in Table 6, and then graphically represented in the shape of stacked bar charts. A principal component analysis (PCA) was used to examine the association between the analyzed traits and the similarity among accessions. PCA was performed with all quantitative traits and the seed color, which was categorized using increasing values for darker colors. Data were analyzed using the software Statgraphics Centurion v.16 (Statpoint Technologies, Warrenton, VA, USA). 
Additionally, for the quantitative traits, a Euclidean distance matrix based on standardized data was computed for clustering analysis by using the UPGMA (unweighted pair group method with arithmetic mean) method (Felsentein, 1973; Mohammadin et al., 2003). Goodness of fit of the resulting dendrogram was evaluated with the cophenetic correlation coefficient by using the Mantel test (Mantel, 1967). This analysis was made using the NTSYSpc2.0 software package (Applied Biostatistics Inc., Setauket, NY, USA).

\subsubsection{Results}

The seed morphology of the accessions was very variable in shape, size, and color (Fig. 9). Five accessions, BGV1165, BGV3618, BGV3941, BGV4161, and BGV15856, exhibited a determinate growth habit; therefore, their plant height and yield-related traits differed significantly from those with indeterminate growth. For this reason, these accessions were excluded from the PCA.

Fig. 9. Seed morphology of the 24 P. vulgaris accessions. 


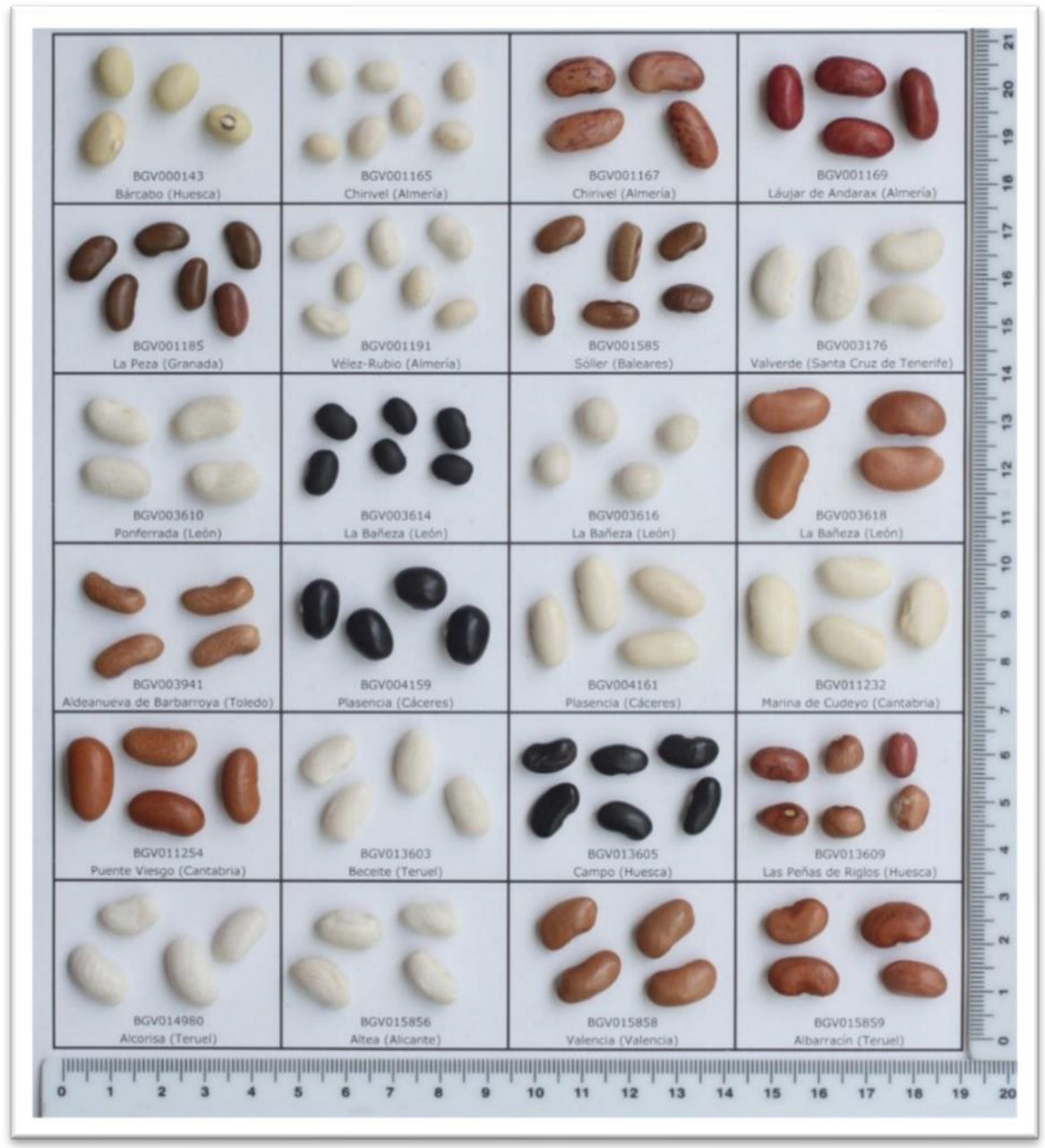

A two-way ANOVA was run to check the possible effect of the environment and the interaction between the genotype and the environment. The results indicated the existence of a significant effect of the environment and the interaction between the genotype and the environment for the majority of traits, especially those related to yield and its components (Table 7). For this reason, data of the two seasons were not merged and were analyzed separately in the PCA and basic statistics calculations.

Table 7. Two-way analysis of variance (ANOVA) of cultivar and cycle effects and their interactions for

\begin{tabular}{|c|c|c|c|}
\hline \multirow{2}{*}{ Dependent Variable } & \multicolumn{2}{|c|}{ Independent Variable } & \multirow[b]{2}{*}{ Cultivar $\times$ Cycle } \\
\hline & Cultivar & Cycle & \\
\hline LeafL (Leaflet length) & $36.42 * * *$ & $0.468 \mathrm{~ns}$ & $0.79 \mathrm{~ns}$ \\
\hline Wcshe (Width of the central sheet) & $46.42 * * *$ & 1.479 ns & $0.97 \mathrm{~ns}$ \\
\hline HypL (Hypocotyl length) & $135.54 * * *$ & $0.480 \mathrm{~ns}$ & $28.52 * * *$ \\
\hline PlantH (Plant height) & $492.86 * * *$ & $3.24 \mathrm{~ns}$ & $0.28 \mathrm{~ns}$ \\
\hline
\end{tabular}




\begin{tabular}{lrrr}
\hline StemD (Stem diameter) & $40.29 * * *$ & $0.055 \mathrm{~ns}$ & $9.85^{* * *}$ \\
FlowBl (Flower buds per inflorescence) & $31.07 * * *$ & $0.09 \mathrm{~ns}$ & $2.57 * * *$ \\
PodL (Pedicel length) & $172.61 * * *$ & $2.05 \mathrm{~ns}$ & $3.40 * * *$ \\
InfloL (Inflorescence length) & $85.31 * * *$ & $14.21 * * *$ & $32.06 * * *$ \\
PedL (Pedicel length) & $70.89 * * *$ & $1.90 \mathrm{~ns}$ & $15.68 * * *$ \\
Pplant (Pods per plant) & $222.09 * * *$ & $3.92 *$ & $0.58 \mathrm{~ns}$ \\
SeedP (Seed per pod) & $31.24 * * *$ & $7.09 * *$ & $1.07 \mathrm{~ns}$ \\
SeedL (Length) & 237.02 & 0.42 & $3.76 * * *$ \\
SeedW (Width) & $73.49 * * *$ & $1.14 \mathrm{~ns}$ & $7.47 * * *$ \\
SeedH (Height) & $71.75 * * *$ & $6.35 *$ & $3.93 * * *$ \\
Yield & $343.70 * * *$ & $2.27 \mathrm{~ns}$ & $4.22 * * *$ \\
\hline$* \mathrm{p}<0.05 ; * \mathrm{p}<0.01 ; * * * \mathrm{p}<0.001 ;$ & $\mathrm{ns}: \mathrm{not}$ significant.
\end{tabular}

\section{Principal Component Analysis and Cluster Analysis.}

To find out which quantitative traits explained most of the variation in the set of accessions studied, a principal components analysis was carried out. The first three components explained $50.6 \%$ of the variation contained in the data $(21.7 \%, 16.7 \%$, and $12.7 \%$ for the first, second, and third components, respectively). The traits more positively correlated with the first PC component were those related to the yield (Yield) and its components (PodL, Pplant, SeedWh, SeedL, SeedW, SeedH) (Table 8, Fig. 10).

The color of the seed coat (Scoatdc) and the apparent seed veining (Aseed) were negatively correlated. Traits related to the size of the leaves (LeafL and Wcshe) were best correlated with the second principal component. Some of the components of yield, pods per plant (Pplant), and seeds per pod (SeedP) also had high positive correlations, while the seed coat color (Scoatdc), seed weight (SeedWh), and seed shape (Shseed) were negatively correlated (Table 8, Fig. 10).

The accessions analyzed were dispersed onto the two main components on the scatter plot of the PCA scores, indicating a large variability (Figure 8). It was also patent a separation of the accessions according to the size and color of their seeds. The accessions with black seeds were located at the top of the graph, mainly due to 
the seed coat color and to the larger size of their leaves, the greater number of seeds per pod, and the narrower shape of the seeds. On the left side of the graph, mostly cultivars with whitish seeds, lower yield, and without apparent seed veining were grouped. Within this group, there was also a remarkable separation according to the second PC, mainly related to the size of leaves and some components of yield. The accessions with brown seeds were also very dispersed, but with a predominance on the right side of the graph, due to their higher yield and larger number of seeds per pod of most cultivars of this type. There were three accessions with different seed coat color; one of them, BGV143, had yellow to greenish-yellow seeds. This accession had very low yield and was in the lower part of the graphic. Contrarily, BGV1 169, with maroon seed coat, was highly productive and grouped with the brown seeds. The accession BGV1185, with gray, brownish to greenish seed color, grouped with the whitish ones, with a very low yield (Figure 8).

Table 8. Correlation coefficients between the first three principal components (PCS) and the morphological descriptors.

\begin{tabular}{lccc}
\hline & Component 1 & Component 2 & Component 3 \\
\hline LeafL & 0.09 & 0.39 & -0.08 \\
Wcshe & 0.08 & 0.38 & -0.14 \\
HypL & 0.09 & 0.04 & 0.17 \\
PlantH & -0.17 & -0.19 & 0.18 \\
StemD & 0.09 & 0.20 & -0.22 \\
Dflow & 0.11 & 0.05 & 0.12 \\
FlowBI & 0.13 & 0.14 & -0.07 \\
PodL & 0.22 & 0.07 & 0.26 \\
InfloL & 0.13 & -0.21 & -0.41 \\
PedL & 0.14 & -0.19 & -0.39 \\
Pplant & 0.22 & 0.27 & 0.14 \\
Dharv & 0.10 & -0.02 & -0.35 \\
SeedP & 0.03 & 0.35 & 0.19 \\
SeedWh & 0.36 & -0.25 & 0.04 \\
SeedL & 0.33 & -0.18 & 0.28 \\
SeedW & 0.33 & -0.15 & -0.13 \\
SeedH & 0.35 & -0.22 & 0.02 \\
\hline & & & \\
\hline
\end{tabular}




\begin{tabular}{llll}
\hline Scoatdc & -0.22 & -0.24 & 0.22 \\
SHseed & 0.20 & -0.23 & 0.23 \\
Aseed & -0.29 & -0.12 & 0.15 \\
Yield & 0.35 & 0.18 & 0.23 \\
\hline
\end{tabular}

Regarding the cluster analysis, in the dendrogram obtained with the morphological traits by the UPGMA method, two main clusters can be observed (I and II,Fig. 12). Cluster I include the accessions encircled in yellow in Fig. 11 and cluster II includes the ones encircled in green color. As expected, the accessions in the cluster analysis were grouped according to the traits related to yield (Yield) and its components (PodL, Pplant, SeedWh, SeedL, SeedW, SeedH). These traits were the most positively correlated with the first PC component in the PCA. In fact, the average values for these traits in the group of accessions included in cluster I (PodL $=15.44$; Pplant $=48.91 ;$ SeedWh $=54.00 ;$ SeedL $=14.16 ;$ SeedW $=6.28 ;$ SeedH $=8.18 ;$ and Yield $=151.52$ ) were consistently higher than the ones for the accessions included in cluster II (PodL = 13.71; Pplant $=22.83 ;$ SeedWh $=40.56 ;$ SeedL $=11.45 ;$ SeedW $=5.63 ;$ SeedH $=7.31 ;$ and Yield $=41.25)$. Also, as in the PCA analysis, the color of the seed was another relevant trait which contributed to the separation of the accessions. Thus, in cluster I, 75\% of the accessions had seeds of brown color, while $55 \%$ of the seeds included in cluster II were white. The cophenetic correlation coefficient of the phenogram obtained from the 20 descriptors used in the analysis had a value of 0.86 .

Fig. 10. Loading plot of the principal component analysis (PCA) conducted with the quantitative traits analyzed in 24 accessions of $P$. vulgaris. Abbreviations are as in Table 6. 


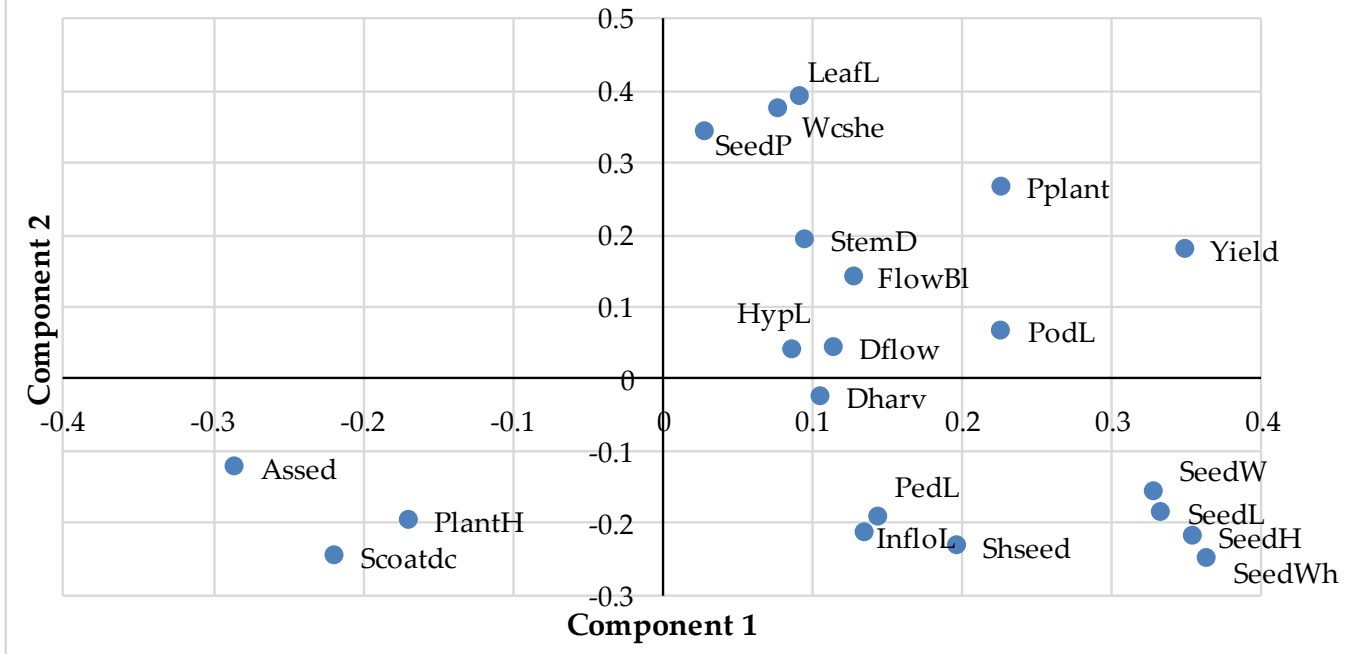

Fig. 11. Scatter plot of the PCA scores.

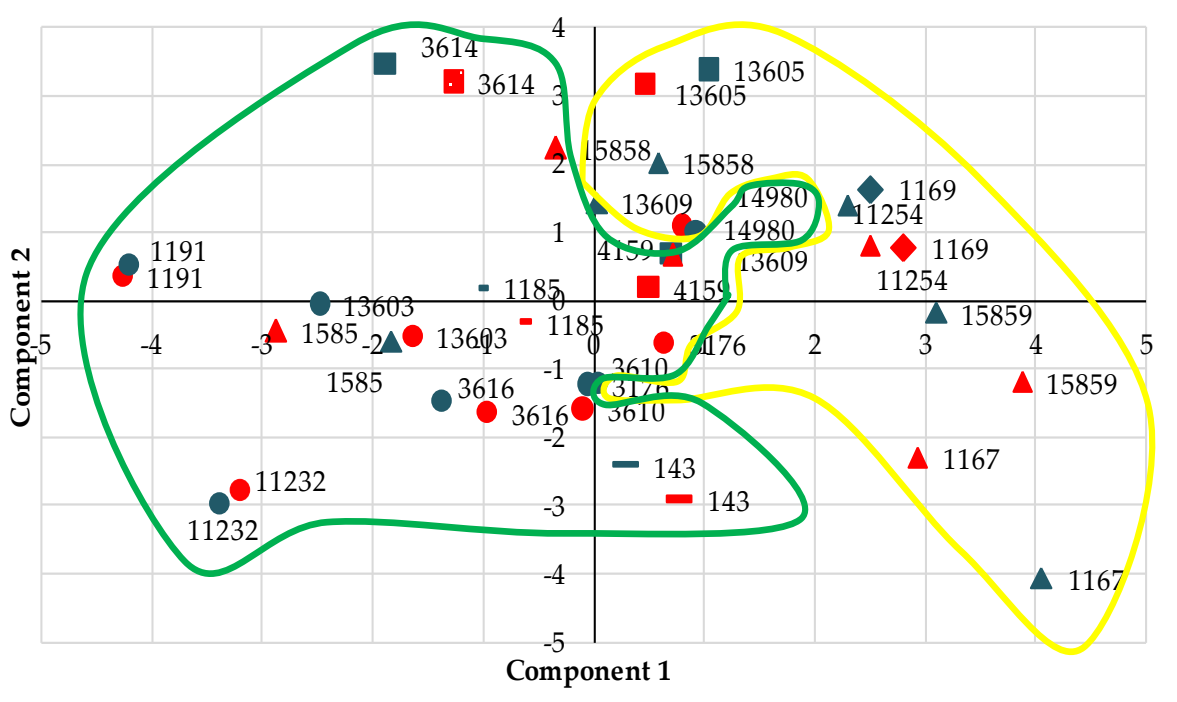

Note: In red, scores of spring trial; in blue, autumn trial. Yellow to greenish-yellow seeds $(-)$, maroon seeds $(\$)$, grey, brownish to greenish seeds (-), black sedes brown, pale to dark seeds $(\Delta)$, whitish seeds $(0)$. Accessions included in the yellow and green areas correspond to the ones included in the two main clusters in Fig. 12. 
Fig. 12. UPCMA (unweighted pair group method with arithmetic mean) phenogram of the 19 accessions of Phaseolus cultivated in two consecutive seasons based on 17 quantitative descriptors.

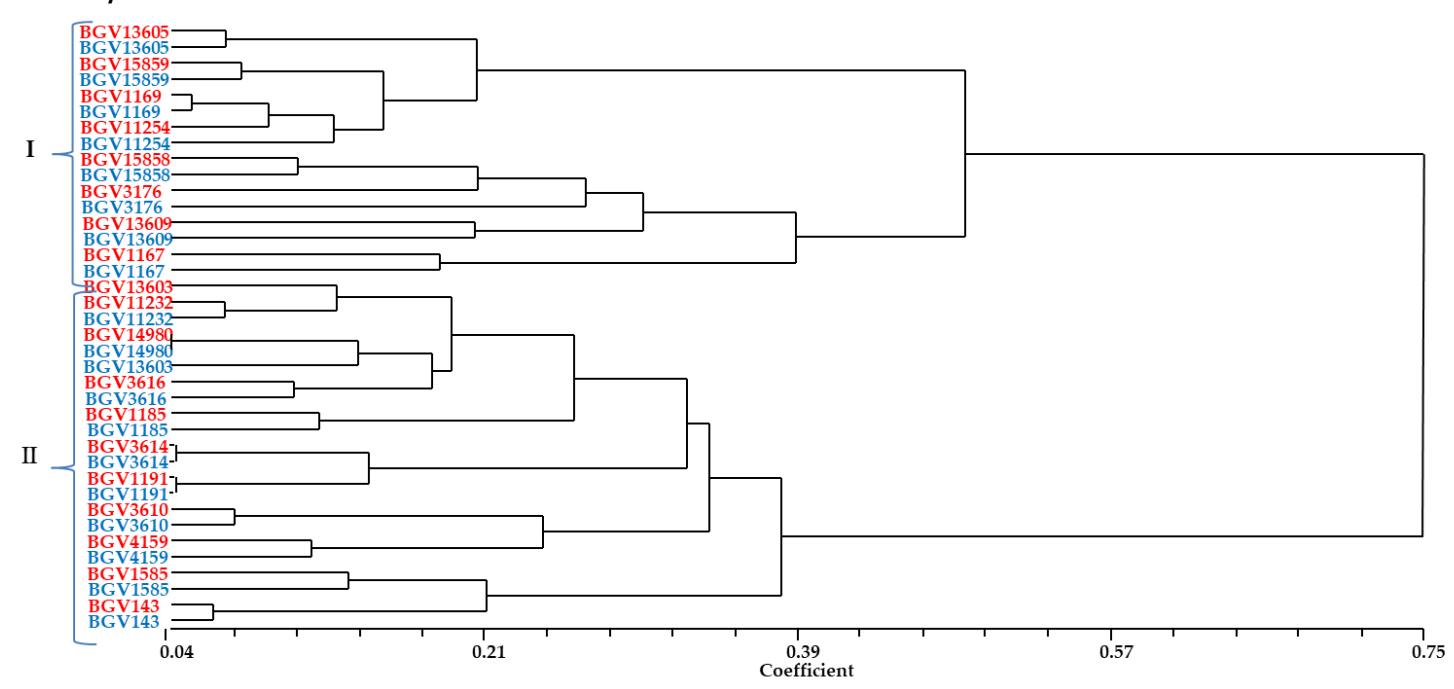

Note: Phenetic relationships were based on Euclidean pairwise distances estimates. I and II represent the two main clusters obtained. In red, scores of spring season; in blue, autumn season.

\section{Description of the Variability of the Whole Set of Accessions and of the Groups}

\section{Established}

For the description of the variability found in the set of accessions, we grouped them according to the seed coat color, establishing three groups: black, brown, and whitish. The three accessions with different colors, BGV143, BGV1169, and BGV1 185, are described separately, as well as the five accessions of determinate growth habit.

\section{Variability of the Whole Set of Accessions}

The whole set of accessions exhibited a high variability for most of the traits evaluated (Table 9 and ¡Error! No se encuentra el origen de la referencia.). Especially relevant was the variation for yield and number of pods per plant, which ranged from 2.8 to $242.8 \mathrm{~g}$ per plant and from five to 72 , respectively. The coefficient of variation for these traits was very high, 82.4 for yield and 59.4 for pods per plant. There was also a great variability for all traits related to inflorescence and some of the components of yield, with coefficient of variation (CV) values that ranged from 31.7 
to 40.4 . The traits that showed lower variation were those related to vegetative characteristics and the height and width of the seeds; in these cases, the CV values ranged from 15.5 to 29 . This trend was similar in the two trials performed. Regarding the qualitative traits recorded, there was little variation for pod cross-section, which was predominately pear-shaped, with pod curvature being straight in general, pod beak position being downward in most cases, and apparent seed veining being absent in general. For the other traits, there was high variation (Figures 10 and 11 )

Fig. 13. Pod traits of the 24 P. vulgaris accessions evaluated.

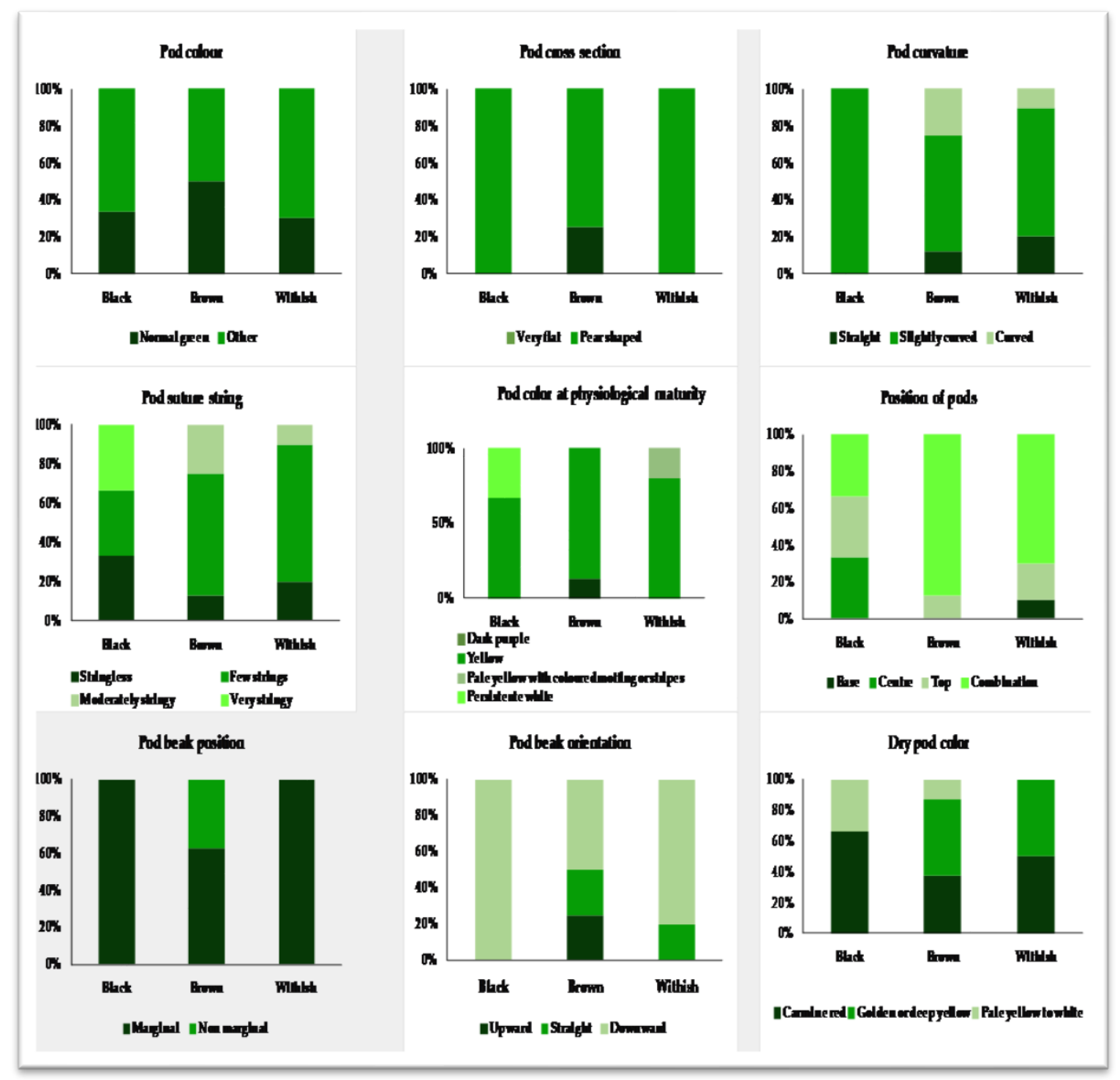


$\underline{\text { Resultados }}$

Table 9. Descriptive statistics for quantitative traits in each of the established groups and the whole set of accessions (number of accessions). Autumn growing season. Units of quantitative traits are as defined inTable 6. CV-coefficient of variation

\begin{tabular}{|c|c|c|c|c|c|c|c|c|c|c|c|c|c|c|c|c|c|c|c|}
\hline Accessions & & HypL & PlantH & StemD & LeafL & Wcshe & Dflow & Dharv & FlowBI & InfloL & PedL & Pplant & PodL & SeedP & SeedL & SeedWh & SeedH & SeedW & Yield \\
\hline \multirow[t]{5}{*}{ All accesions } & Mean & 10.53 & 1.70 & 5.18 & 16.51 & 11.48 & 42.54 & 110.25 & 4.17 & 7.65 & 3.77 & 29.15 & 14.26 & 5.09 & 12.96 & 47.14 & 7.77 & 5.94 & 74.53 \\
\hline & $S D$ & 3.05 & 0.69 & 1.26 & 3.76 & 3.22 & 6.65 & 23.08 & 1.42 & 2.42 & 1.55 & 17.31 & 4.28 & 1.87 & 3.07 & 17.29 & 1.20 & 1.14 & 61.41 \\
\hline & $C V$ & 28.98 & 40.39 & 24.35 & 22.74 & 28.02 & 15.64 & 20.94 & 34.04 & 31.69 & 41.16 & 59.38 & 30.04 & 36.78 & 23.68 & 36.68 & 15.49 & 19.24 & 82.39 \\
\hline & Range & 2.80 & 0.32 & 2.75 & 9.80 & 5.40 & 28.00 & 71.00 & 1.00 & 2.71 & 1.10 & 5.00 & 5.60 & 1.00 & 7.03 & 17.20 & 4.72 & 3.64 & 2.80 \\
\hline & & 19.00 & 2.95 & 8.40 & 26.50 & 20.20 & 55.00 & 157.00 & 8.00 & 14.60 & 8.10 & 72.00 & 28.50 & 9.00 & 21.39 & 81.40 & 11.49 & 8.71 & 242.75 \\
\hline \multirow[t]{5}{*}{ Black (3) } & Mean & 10.73 & 1.85 & 5.50 & 20.26 & 15.84 & 41.00 & 117.33 & 4.05 & 8.29 & 4.23 & 43.47 & 12.66 & 6.17 & 10.45 & 33.89 & 7.40 & 5.76 & 92.49 \\
\hline & $S D$ & 1.23 & 0.32 & 0.70 & 3.53 & 2.51 & 5.57 & 29.69 & 1.43 & 1.88 & 2.06 & 16.97 & 3.36 & 2.20 & 1.74 & 15.67 & 1.01 & 1.19 & 62.28 \\
\hline & $C V$ & 11.50 & 17.44 & 12.77 & 17.44 & 15.83 & 13.58 & 25.30 & 35.35 & 22.67 & 48.64 & 39.03 & 26.53 & 35.65 & 16.64 & 46.25 & 13.59 & 20.71 & 67.33 \\
\hline & Range & 9.1 & 0.99 & 4.2 & 16 & 11 & 36 & 92 & 2 & 5.9 & 1.9 & 23 & 8 & 1 & 7.5 & 19.2 & 5.62 & 4.38 & 34.52 \\
\hline & & 12.6 & 2.4 & 6.5 & 26.5 & 20.2 & 47 & 150 & 6 & 12.1 & 8.1 & 72 & 18.5 & 9 & 12.77 & 50.39 & 9.77 & 8.71 & 193.95 \\
\hline \multirow[t]{5}{*}{ Brown (8) } & Mean & 10.67 & 2.28 & 5.88 & 16.05 & 10.89 & 43.83 & 114.17 & 3.98 & 6.97 & 3.63 & 39.66 & 13.94 & 5.64 & 13.91 & 60.09 & 7.95 & 5.96 & 124.67 \\
\hline & $S D$ & 2.70 & 0.38 & 1.41 & 3.48 & 2.43 & 8.86 & 22.99 & 1.39 & 1.46 & 1.48 & 17.69 & 3.76 & 1.68 & 2.95 & 17.82 & 1.47 & 1.34 & 57.97 \\
\hline & $C V$ & 25.30 & 16.82 & 23.99 & 21.68 & 22.28 & 20.22 & 20.14 & 34.88 & 20.98 & 40.84 & 44.62 & 26.99 & 29.75 & 21.23 & 29.65 & 18.47 & 22.56 & 46.50 \\
\hline & Range & 4.5 & 1.75 & 2.9 & 9.8 & 7.8 & 35 & 94 & 1 & 3.8 & 1.1 & 5 & 5.6 & 2 & 9.49 & 37.45 & 5 & 3.64 & 18.97 \\
\hline & & 14.5 & 2.95 & 8.4 & 22.4 & 19.2 & 55 & 143 & 6 & 10.9 & 7 & 65 & 21.2 & 8 & 18.69 & 81.4 & 10.74 & 8.16 & 242.75 \\
\hline \multirow{6}{*}{ Whitish (10) } & Mean & 11.64 & 1.80 & 4.52 & 16.32 & 11.55 & 45.29 & 112.14 & 3.89 & 6.57 & 3.20 & 26.30 & 15.92 & 5.02 & 12.52 & 39.56 & 7.44 & 5.52 & 54.07 \\
\hline & $S D$ & 2.93 & 0.20 & 0.84 & 2.92 & 2.78 & 2.69 & 21.07 & 1.49 & 2.89 & 1.32 & 10.51 & 5.25 & 1.89 & 2.84 & 12.86 & 1.06 & 0.92 & 38.14 \\
\hline & $C V$ & 25.21 & 11.34 & 18.47 & 17.90 & 24.05 & 5.94 & 18.79 & 38.20 & 43.95 & 41.34 & 39.96 & 32.99 & 37.71 & 22.70 & 32.50 & 14.28 & 16.71 & 70.54 \\
\hline & Range & 7.8 & 1.2 & 2.75 & 11.1 & 7.2 & 41 & 87 & 2 & 2.71 & 1.1 & 8 & 9.8 & 2 & 7.41 & 19 & 4.72 & 3.89 & 15.14 \\
\hline & & 19 & 2.4 & 7.83 & 25 & 19.8 & 50 & 141 & 8 & 14.6 & 7.8 & 47 & 28.5 & 9 & 18.09 & 53.2 & 8.98 & 8.01 & 146.83 \\
\hline & Mean & 8.56 & 1.79 & 4.33 & 14.04 & 9.44 & 46 & 98.00 & 4.25 & 11.78 & 5.25 & 15.20 & 14.22 & 5.00 & 11.34 & 53.20 & 8.69 & 7.70 & 40.43 \\
\hline \multirow{4}{*}{$\begin{array}{l}\text { Yellow to greenish } \\
\text { yellow (1) }\end{array}$} & $S D$ & 0.74 & 0.02 & 0.69 & 3.48 & 1.23 & - & - & 1.71 & 1.87 & 1.37 & 3.49 & 1.20 & 0.71 & 0.58 & - & 1.15 & 0.38 & 9.29 \\
\hline & $C V$ & 8.65 & 1.34 & 16.03 & 24.80 & 13.08 & - & - & 40.18 & 15.91 & 26.14 & 22.98 & 8.47 & 14.14 & 5.16 & - & 13.23 & 4.90 & 22.98 \\
\hline & Range & 7.8 & 1.75 & 3.67 & 10.1 & 7.3 & 46 & 98 & 2 & 9 & 3.2 & 11 & 12.2 & 4 & 10.16 & 53.2 & 7.22 & 6.99 & 29.26 \\
\hline & & 9.5 & 1.81 & 5.3 & 20 & 10.9 & 46 & 98 & 6 & 13 & 6.1 & 20 & 15.2 & 6 & 12.06 & 53.2 & 11.49 & 8.11 & 53.2 \\
\hline Gray, brownish to & Mean & 6.18 & 1.80 & 6.04 & 17.68 & 13.50 & 37.00 & 157.00 & 4.33 & 7.67 & 4.05 & 12.00 & 13.95 & 4.50 & 12.23 & 38.60 & 7.90 & 5.62 & 20.84 \\
\hline greenish (1) & $S D$ & 1.80 & - & 1.41 & 1.15 & 1.09 & - & - & 1.21 & 0.82 & 0.61 & 3.39 & 0.90 & 0.84 & 0.90 & - & 0.32 & 0.34 & 5.89 \\
\hline
\end{tabular}




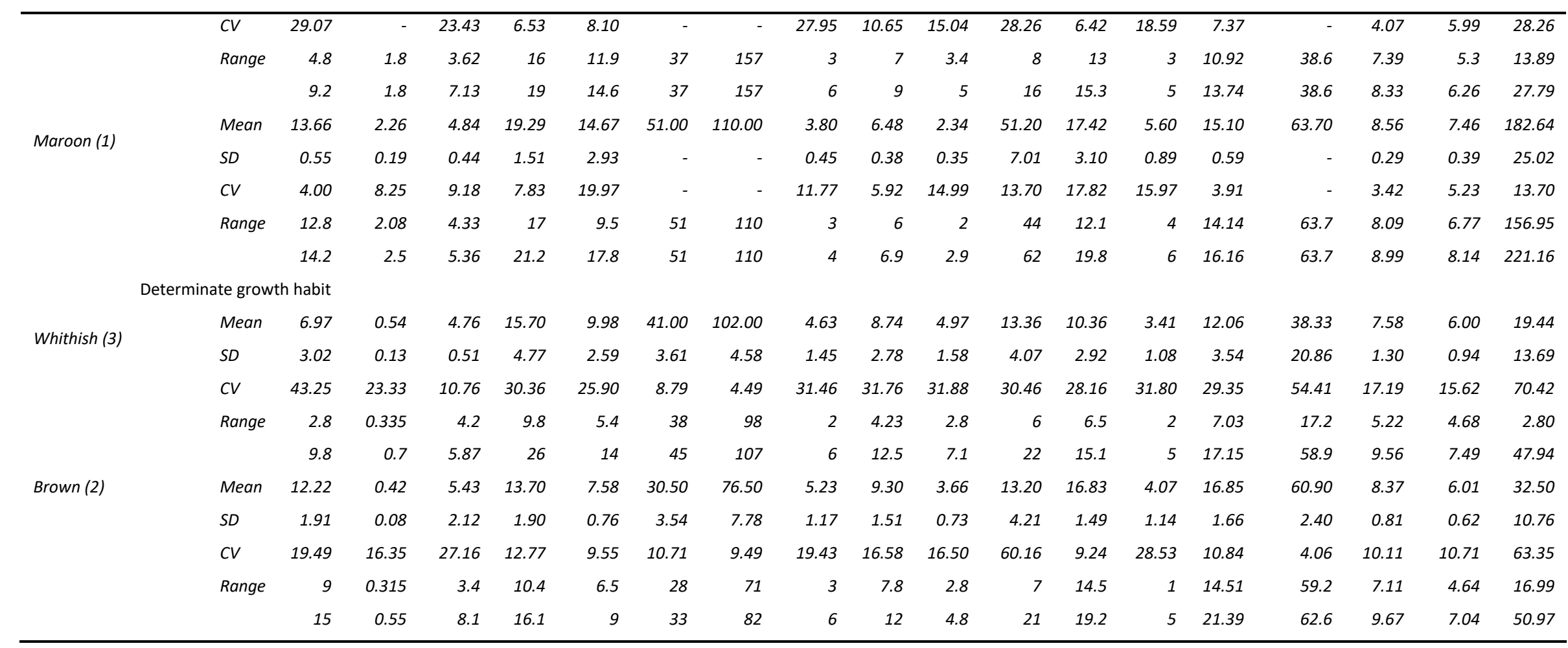


Table 10. Descriptive statistics for quantitative traits in each of the established groups and the whole set of accessions (number of accessions). Spring growing season Units of quantitative traits are as defined in Table 6.

\begin{tabular}{|c|c|c|c|c|c|c|c|c|c|c|c|c|c|c|c|c|c|c|c|}
\hline Accessions & & Hypl & PlantH & StemD & LeafL & Wcshe & Dflow & Dharv & FlowBI & InfloL & PedL & Pplant & PodL & SeedP & SeedL & SeedWh & SeedH & SeedW & Yield \\
\hline \multirow[t]{5}{*}{ All accessions } & Mean & 10.59 & 1.69 & 5.13 & 17.03 & 12.11 & 42.25 & 108.5 & 4.18 & 7.38 & 3.57 & 30.14 & 14.38 & 5.34 & 12.91 & 46.15 & 7.65 & 5.89 & 76.06 \\
\hline & $S D$ & 3.03 & 0.66 & 1.06 & 3.87 & 3.26 & 8.41 & 21.86 & 1.51 & 2.97 & 1.62 & 18.02 & 3.98 & 1.76 & 2.97 & 16.56 & 1.04 & 0.99 & 61.71 \\
\hline & $C V$ & 28.65 & 39.02 & 20.73 & 22.75 & 26.88 & 19.92 & 20.15 & 36.15 & 40.2 & 45.37 & 59.78 & 27.67 & 33.02 & 23.01 & 35.89 & 13.6 & 16.77 & 81.13 \\
\hline & Range & 2 & 0.25 & 3.14 & 9.8 & 6.5 & 27 & 70 & 1 & 1.5 & 0.98 & 4 & 6.8 & 1 & 6.59 & 16.98 & 5.41 & 4.03 & 6.99 \\
\hline & & 17.8 & 2.98 & 7.87 & 26.5 & 20.5 & 55 & 153 & 9 & 25.54 & 12.22 & 77 & 27.8 & 9 & 21.17 & 76.23 & 10.15 & 9.38 & 232.82 \\
\hline \multirow[t]{5}{*}{ Black (3) } & Mean & 12.15 & 1.88 & 5.04 & 20.31 & 15.82 & 42.33 & 121.33 & 4.52 & 7.47 & 3.41 & 44.4 & 12.83 & 6.67 & 10.52 & 35.29 & 7.23 & 5.68 & 108.08 \\
\hline & $S D$ & 2.95 & 0.18 & 0.97 & 3.44 & 1.68 & 6.43 & 28.18 & 1.36 & 1.92 & 1.52 & 18.71 & 4.31 & 1.83 & 2.04 & 17.4 & 1.01 & 1.13 & 75.21 \\
\hline & $C V$ & 24.28 & 9.39 & 19.31 & 16.96 & 10.6 & 15.19 & 23.23 & 30.16 & 25.7 & 44.61 & 42.13 & 33.62 & 27.39 & 19.43 & 49.3 & 13.91 & 19.83 & 69.58 \\
\hline & Range & 8.9 & 1.7 & 3.9 & 16.2 & 13.6 & 35 & 99 & 2 & 5.5 & 2.1 & 21 & 8 & 4 & 7.24 & 18.374 & 5.76 & 4.1 & 33.56 \\
\hline & & 17.8 & 2.4 & 7.87 & 26.5 & 19.5 & 47 & 153 & 6 & 12 & 7.8 & 77 & 19.4 & 9 & 13.32 & 53.13 & 8.99 & 7.78 & 232.82 \\
\hline \multirow[t]{5}{*}{ Brown (8) } & Mean & 11.93 & 2.27 & 5.34 & 16.91 & 11.84 & 44 & 113.33 & 4.05 & 7.35 & 3.56 & 41.73 & 14.53 & 6.23 & 13.54 & 54.67 & 8.02 & 6.25 & 123.87 \\
\hline & $S D$ & 1.3 & 0.41 & 1.19 & 3.9 & 2.78 & 9.01 & 25.08 & 1.69 & 3.73 & 1.78 & 18.74 & 3.42 & 1.55 & 2.45 & 16.18 & 1.08 & 0.91 & 57.58 \\
\hline & $C V$ & 10.92 & 18.15 & 22.27 & 23.04 & 23.5 & 20.48 & 22.13 & 41.82 & 50.74 & 50.06 & 44.91 & 23.51 & 24.85 & 18.12 & 29.61 & 13.41 & 14.53 & 46.48 \\
\hline & Range & 9.8 & 1.6 & 3.35 & 9.8 & 7.8 & 34 & 91 & 2 & 3.8 & 1.9 & 4 & 6.8 & 2 & 9 & 36.18 & 5.46 & 4.27 & 18.688 \\
\hline & & 14.5 & 2.98 & 7.83 & 24.5 & 19.2 & 54 & 147 & 9 & 25.54 & 12.22 & 65 & 21.2 & 8 & 17.7 & 76.23 & 9.65 & 9.38 & 217.47 \\
\hline \multirow[t]{5}{*}{ Whitish (10) } & Mean & 10.63 & 1.81 & 4.88 & 15.95 & 11.79 & 43.86 & 111.29 & 3.39 & 6.04 & 2.87 & 26.09 & 15.5 & 5.1 & 12.56 & 39.39 & 7.43 & 5.43 & 51.36 \\
\hline & $S D$ & 2.65 & 0.19 & 0.88 & 3.33 & 3.02 & 8.13 & 20.85 & 1.27 & 2.03 & 1.06 & 10.44 & 4.88 & 1.81 & 2.53 & 11.38 & 0.98 & 0.92 & 30.47 \\
\hline & $C V$ & 24.92 & 10.69 & 17.95 & 20.87 & 25.58 & 18.54 & 18.74 & 37.51 & 33.7 & 36.96 & 40.04 & 31.46 & 35.58 & 20.14 & 28.89 & 13.19 & 16.95 & 59.33 \\
\hline & Range & 5.4 & 1.31 & 3.14 & 11.1 & 7.5 & 27 & 85 & 1 & 3.2 & 0.98 & 9 & 7.9 & 2 & 8.01 & 19.534 & 5.41 & 4.03 & 17.17 \\
\hline & & 15.6 & 2.5 & 7.8 & 25.2 & 20.5 & 53 & 138 & 6 & 14.3 & 6 & 45 & 27.8 & 8 & 17.4 & 49.1 & 9.36 & 7.9 & 128.79 \\
\hline \multirow[t]{5}{*}{ Yellow to greenish yellow } & Mean & 8.22 & 1.8 & 4.88 & 14 & 9.55 & 49 & 98 & 4.4 & 11.48 & 4.28 & 16.2 & 13.08 & 4.8 & 10.49 & 56.1 & 7.85 & 7.27 & 43.62 \\
\hline & $S D$ & 0.83 & 0.05 & 0.59 & 3.35 & 1.24 & - & - & 1.52 & 1.43 & 0.47 & 5.89 & 0.27 & 1.1 & 0.67 & - & 0.54 & 0.45 & 15.86 \\
\hline & $C V$ & 10.08 & 2.53 & 12.07 & 23.92 & 12.99 & - & - & 34.47 & 12.43 & 11.01 & 36.36 & 2.05 & 22.82 & 6.38 & - & 6.83 & 6.15 & 36.36 \\
\hline & Range & 7.2 & 1.76 & 3.94 & 10.1 & 7.3 & 49 & 98 & 2 & 9 & 3.9 & 9 & 12.8 & 3 & 9.64 & 56.1 & 6.78 & 6.69 & 24.23 \\
\hline & & 9.1 & 1.88 & 5.45 & 20 & 10.9 & 49 & 98 & 6 & 12.5 & 5.1 & 23 & 13.5 & 6 & 11.63 & 56.1 & 8.43 & 7.91 & 61.93 \\
\hline
\end{tabular}




\begin{tabular}{|c|c|c|c|c|c|c|c|c|c|c|c|c|c|c|c|c|c|c|c|}
\hline \multirow[t]{5}{*}{ Gray, brownish to greenish } & Mean & 7.32 & 1.8 & 6.8 & 17.3 & 13.56 & 40 & 125 & 4.6 & 8.58 & 4.4 & 12.8 & 14.96 & 4.6 & 11.93 & 37.05 & 6.86 & 5.22 & 21.82 \\
\hline & $S D$ & 1.7 & 0.09 & 0.46 & 1.37 & 0.88 & - & - & 1.14 & 1.06 & 1.01 & 1.92 & 0.47 & 0.52 & 0.82 & - & 0.37 & 0.35 & 3.28 \\
\hline & $C V$ & 23.25 & 5.06 & 6.74 & 7.95 & 6.53 & - & - & 24.79 & 12.4 & 22.9 & 15.03 & 3.16 & 11.23 & 6.85 & - & 5.39 & 6.61 & 15.03 \\
\hline & Range & 5.6 & 1.65 & 6.3 & 15.8 & 12.5 & 40 & 125 & 3 & 6.9 & 3.2 & 10 & 14.5 & 4 & 10.71 & 37.05 & 6.08 & 4.48 & 17.04 \\
\hline & & 9.2 & 1.89 & 7.5 & 19.2 & 14.6 & 40 & 125 & 6 & 9.5 & 5.5 & 15 & 15.6 & 5 & 12.91 & 37.05 & 7.39 & 5.65 & 25.56 \\
\hline \multirow[t]{5}{*}{ Maroon } & Mean & 9.6 & 2.12 & 6.55 & 19.5 & 15.1 & 55 & 110 & 4.33 & 6.4 & 2.6 & 55.2 & 17.68 & 5.67 & 14.18 & 59.01 & 8.15 & 6.82 & 184.58 \\
\hline & $S D$ & 2.54 & 0.03 & 0.92 & 1.49 & 3.05 & - & - & 1.86 & 0.23 & 0.4 & 6.61 & 1.68 & 0.82 & 0.79 & - & 0.45 & 0.62 & 22.11 \\
\hline & $C V$ & 26.43 & 1.36 & 14 & 7.66 & 20.21 & - & - & 42.97 & 3.56 & 15.38 & 11.98 & 9.49 & 14.41 & 5.54 & - & 5.49 & 9.14 & 11.98 \\
\hline & Range & 4.8 & 2.1 & 5.53 & 17 & 9.5 & 55 & 110 & 3 & 6.2 & 2.1 & 48 & 14.8 & 4 & 12.75 & 59.01 & 7.26 & 5.6 & 160.50 \\
\hline & & 11.5 & 2.15 & 7.31 & 21.2 & 17.8 & 55 & 110 & 8 & 6.8 & 3.1 & 63 & 19.1 & 6 & 15.27 & 59.01 & 8.58 & 7.68 & 210.66 \\
\hline \multicolumn{20}{|c|}{ Determinate growth habit } \\
\hline \multirow[t]{5}{*}{ Whitish (3) } & Mean & 7.28 & 0.54 & 4.81 & 17.59 & 11.03 & 39 & 98.67 & 5 & 8.11 & 4.99 & 14.8 & 10.96 & 3.89 & 12.44 & 34.8 & 7.36 & 5.48 & 21 \\
\hline & $S D$ & 3.64 & 0.15 & 0.78 & 4.59 & 1.81 & 3.61 & 7.09 & 1.07 & 3.66 & 2.35 & 2.93 & 2.83 & 0.89 & 3.64 & 15.99 & 1.04 & 0.5 & 11.64 \\
\hline & $C V$ & 49.93 & 28.18 & 16.2 & 26.11 & 16.39 & 9.25 & 7.19 & 21.38 & 45.11 & 47.11 & 19.81 & 25.87 & 22.93 & 29.27 & 45.96 & 14.14 & 9.2 & 55.41 \\
\hline & Range & 2 & 0.251 & 3.82 & 12 & 8 & 35 & 91 & 3 & 1.5 & 2.1 & 10 & 7 & 2 & 6.59 & 16.98 & 5.5 & 4.83 & 6.98 \\
\hline & & 13.2 & 0.67 & 6.05 & 26 & 14 & 42 & 105 & 6 & 15 & 10.1 & 21 & 15.5 & 5 & 17.2 & 47.91 & 8.9 & 6.71 & 42.25 \\
\hline \multirow[t]{5}{*}{ Brown (2) } & Mean & 12.61 & 0.41 & 4.87 & 13.73 & 7.42 & 27.5 & 76 & 5.22 & 9.04 & 4.31 & 14.3 & 15.26 & 4.28 & 17.59 & 70.69 & 8.48 & 6.52 & 42.72 \\
\hline & $S D$ & 2.2 & 0.08 & 1.21 & 2.02 & 0.63 & 0.71 & 8.49 & 1.09 & 3.29 & 1.26 & 2.98 & 1.41 & 1.02 & 1.74 & 7.78 & 0.9 & 0.58 & 7.82 \\
\hline & $C V$ & 17.47 & 19.21 & 24.77 & 14.73 & 8.54 & 2.57 & 11.16 & 20.93 & 36.36 & 29.17 & 20.86 & 9.24 & 23.79 & 9.89 & 11 & 10.58 & 8.83 & 18.31 \\
\hline & Range & 7 & 0.285 & 3.49 & 10.4 & 6.5 & 27 & 70 & 3 & 5.1 & 2.3 & 8 & 13.5 & 1 & 14.89 & 65.189 & 7.15 & 5.52 & 25.14 \\
\hline & & 15.1 & 0.531 & 7.19 & 16.1 & 8 & 28 & 82 & 6 & 13.1 & 6.2 & 19 & 17.2 & 5 & 21.17 & 76.19 & 10.15 & 7.49 & 54.49 \\
\hline
\end{tabular}


Resultados

\section{Description of the Three Accessions with Black-Colored Seeds}

Accessions with black seeds were the most leafy, with a higher mean value of central leaflet length and width, long inflorescences and peduncles, and a high number of pods per plant (Pplant) (on average 43.47 in the first cycle and 44.40 in the second, compared with the mean values for the whole set of accessions that were 29.15 and 30.14 , respectively). These cultivars had the smallest seeds and, therefore, more seeds per pod than those from other groups (Table 9 and Table 10). The average yield was high (92 in the first cycle, and 108 in the second), with a high coefficient of variation, as the yield ranged from 34 to 193 in the first cycle and from 33 to 239 in the second cycle. Qualitative traits ( Fig. 13 and Fig. 14) showed only a relatively smaller variation in comparison to the other group of cultivars, without any seed coat patterns or apparent seed veining, with seeds either matte or medium brilliant, and only two shapes, either oval or cuboid. No variation was registered for the trait pod beak position (marginal in all cultivars), pod beak orientation (upward), or pod crosssection (pear-shaped).

Fig. 14. Seed traits of the 24 P. vulgaris accessions evaluated.
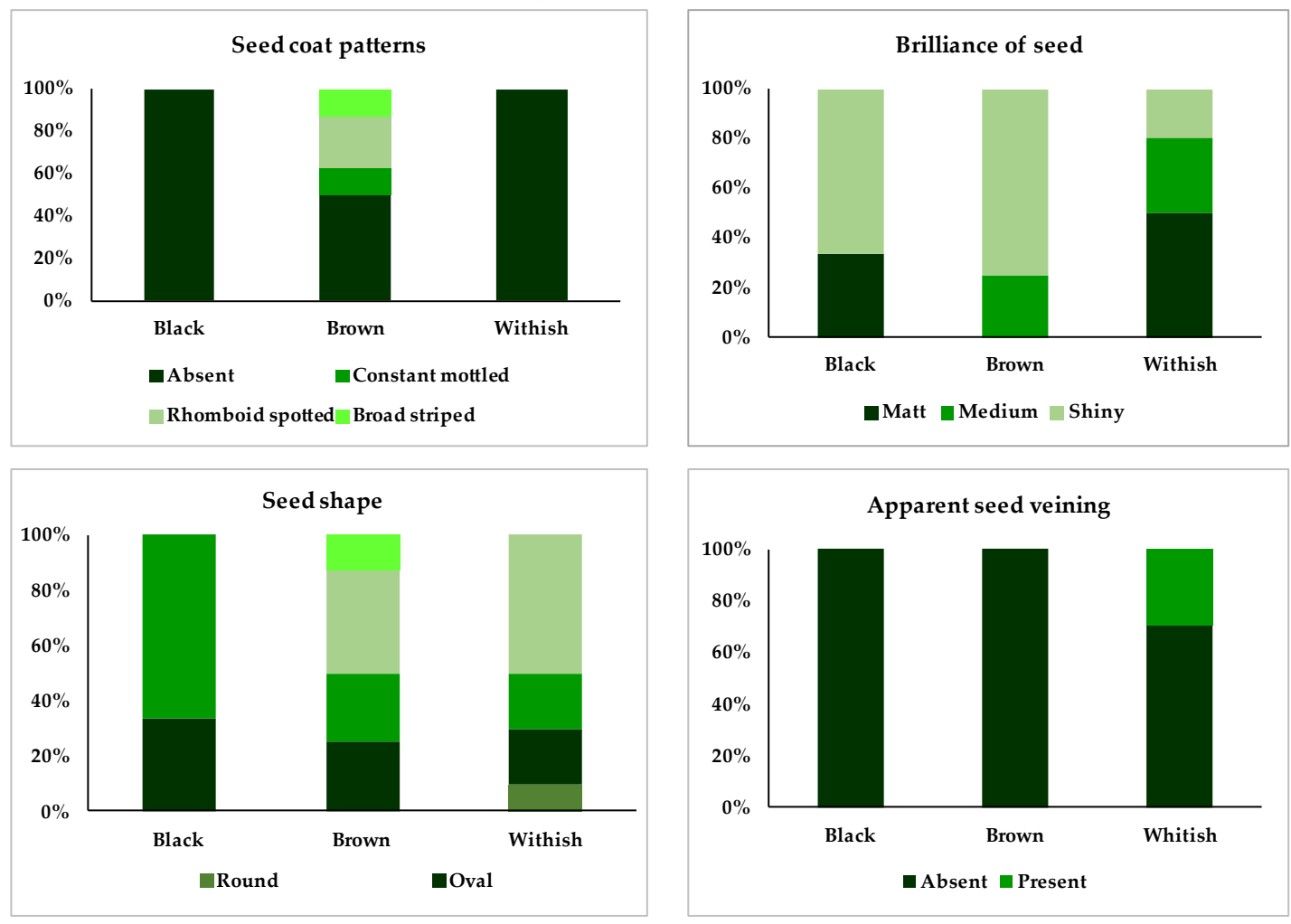


\section{Description of the Six Accessions with Brown-Colored Seeds}

Accessions with brown seeds included the most robust plants, with plant height ranging from 1.75 to $2.95 \mathrm{~m}$ in the first cycle, and from 1.6 to $2.98 \mathrm{~m}$ in the second one, with a larger stem diameter (Table 9 and Table 10). The highest average yield was found for this group; the coefficient of variation for this characteristic was very high, $46 \%$ in both cycles, mainly due to the large variation in the number of pods per plant, ranging from five to 65 and from four to 65 , respectively. The group had the largest seeds, most notable in the weight of seeds $(100$ seeds weighed $60 \mathrm{~g}$ in the first cycle and $54 \mathrm{~g}$ in the second one). Among the qualitative characteristics (Fig. 13 and Fig. 14), the seed coat pattern was outstanding and the most variable in comparison to the other groups. Furthermore, high variability was registered for the shape of seeds (including cultivars with ovoid, cuboid, and kidney-shaped seeds), the brilliance of seeds (medium and shiny), variable pod beak orientation (upward, straight, downward), and pod suture string (from stingless to very stringy). No variation was found for apparent seed veining, being absent in all cases.

\section{Description of the Seven Accessions with White-Colored Seeds}

Accessions with whitish seeds had generally smaller plants, with fewer pods per plant (26 in both cycles), smaller seeds, with a weight of $39 \mathrm{~g}$ for 100 seeds (in both cycles). The number of seeds per pod was also generally smaller and, therefore, the mean yield was much lower in comparison to the other accessions $(54 \mathrm{~g}$ per plant in the first cycle and 51 in the second one), representing less than half of that registered for the group with brown seeds (Table 9 and Table 10). However, the coefficient of variation of this trait was high, as some cultivars were much more productive than the others (e.g., BGV 3176 with $132 \mathrm{~g}$ per plant). Among the qualitative traits, the seed shape was more variable than in other groups; most of the cultivars had kidneyshaped seeds, but there were also some with cuboid, round, and oval seeds (Fig. 14). 
Seeds coat patterns were absent, but seed brilliance varied from matte to shiny, and an apparent seed veining was detected only in this group.

\section{Description of the Accessions with Different Seed Colors and of the Accessions} with a Determinate Growth Habit

There were three accessions with seed coat color different from the ones described above. The accession BGV1169 had maroon seeds, BGV1185 exhibited gray, brownish-greenish seeds, and BGV143 had yellow to greenish-yellow-colored seeds. The three accessions differed in many traits. For vegetative traits, BGV1169 developed bigger leaves, both in length and width, and a short period from flowering to the harvest of the pods (59 days). It was also the most productive, with $182 \mathrm{~g}$ per plant, with higher values for the components of yield. In contrast, the accession BGV1185 was the one with the lowest yield (20.8 g per plant) and with the most prolonged period from flowering to harvest (120 days). The accession BGV143 had intermediate values for all traits, as well as outstanding inflorescence length and pedicel length; it showed the shortest period from flowering to harvest (52 days). The behavior of the three accessions was similar in both cycles. The growth habit of BGV143, BGV1 169, and BGV1 185 was climbing indeterminate. The color of the pod was light green for the cultivars BGV143 and BGV1185 and normal green for BGV1 169. The cross-section and curvature of the pod were pear-shaped and slightly curved for all cultivars. BGV1 169 did not present ventral suture in the sheaths, while the rest were very fibrous. The pods of the cultivars BGV1169 and BGV1185 at physiological maturity were yellow and pale yellow for BGV143 with colored mottling or stripes. The position of the pods in the plant was combined for BGV143 and BGV1 185, while for BGV1 169 the pods were concentrated in the center. The position and orientation of the apex of the pods were marginal and downward (downward). The dry pod color was golden or deep yellow (BGV1 169) and carmine red (BGV143 and BGV1 185). The seed coat patterns were absent for the three cultivars, and the 
seed brilliance was medium for BGV1 169 and BGV143 and shiny in BGV1185. The seed shape was kidney-shaped (BGV1169 and BGV1185) and kidney pronged (BGV143). In all three cultivars, no ribs were observed in the seeds.

Regarding the accessions with determinate growth habit, there were two with brown seeds and three with whitish seeds. All of them had small plants, less than 0.5 $\mathrm{m}$ in height with narrow leaves. Accessions with brown seeds were very early and showed a short period from flowering to harvest (46 days). All accessions exhibited a high number of flower buds per inflorescence and low numbers of pods per plant and seeds per pod, giving rise to a low yield. Accessions with brown seeds were more productive than those with whitish seeds, because of their higher pod length, number of seeds per pod, and length and width of the seeds.

\subsubsection{Discussion}

Analysis of the complete set of accessions highlighted the great variability for most of the 32 characteristics evaluated. A high diversity was also reported in previous works on bean collections of Spanish origin (Gil et al., 1992; Rodiño et al., 2003). It is also evident the diversity of types in terms of size, color, and shape of seeds, as well as for other characteristics related to the main differences between the two gene pools, the Mesoamerican and the Andean; they include the size and shape of the terminal trifoliolate leaflet, flower bracteoles, the presence or absence of stripes at the outer base of the flower standard, and the pod beak position. Our findings support results obtained by other authors who demonstrated that, in the Iberian Peninsula, after centuries of joint cultivation, a mixture of the two pools of germplasm occurred. This was already revealed, based on morphological studies, phaseolin protein patterns, and molecular markers (Rodiño et al., 2003; Perez-Vega et al., 2009). The existence of both pools represents an added value to the Spanish germplasm. This high variability of Spanish accessions is of great value for their adaptation to the environmental conditions of both areas of domestication of this 
crop. Additionally, they may be used as a bridge for the transfer of genes between accessions belonging to both gene pools, as already suggested by Rodiño et al. [32]. Additionally, they may be used as a bridge for the transfer of genes between accessions belonging to both gene pools, as already suggested by Rodiño et al. (Rodiño et al., 2003).

The cluster and PCA analyses were congruent, and they clearly separated the accessions for their yield and yield components, mainly those related to pods and seeds, as well as their seed color. These characteristics are much more important in explaining the diversity of bean types in Spain, in contrast to other traits related to plant growth and earliness. The lack of grouping of accessions of different origin reflects a lack of regional differentiation, probably caused by transport by humans and seed exchange between farmers.

The high number of traits exhibiting interactions between the genotype and the environment, when cultivated in spring and autumn, is in agreement with previous reports (Vaid, et al., 1985; Escribano et al., 1994). Also, Nienhuis and Singh (1986) and Sills and Nienhuis (1993) reported environmental effects in the expression of quantitative traits in different types of beans. This means that the best genotype for one environment may not be the best for another one and, therefore, specific types of beans must be developed for cultivation in different environments (Hosfield et al., 1984). In our trial, the main differential environmental factor between the two growing seasons, autumn and spring, was the solar radiation, as shown in Figure 2, while the temperature and relative humidity were controlled in the greenhouse. Approximately $50 \%$ of the accessions did not show a great variation in yield when comparing the two seasons. However, the other accessions showed variation, most reaching higher yields in spring, in which solar radiation favors photosynthesis and, consequently, photoassimilation, regardless of the geographic origin of the accessions. The different response to the changing environment of the set of 
accessions studied in the present work is of great interest, and it can be exploited in breeding cultivars adapted to a broader range of environmental conditions.

The standard deviation values for seed weight, seed length, and seed width were higher than those reported by Escribano et al. (Escribano et al., 1998), who studied a set of 66 landraces collected in Galicia (Spain). The same occurred for traits related to vegetative characteristics, such as length (LeafL) and width of the leaflet (Wcshe), and other traits of the pods and seeds. The range of variation for these traits was also higher in the set of accessions studied in the present work than in the germplasm studied by Rodiño et al. (2003), which consisted of a group of 388 cultivars collected in the major production regions of the Iberian Peninsula and a core collection of 52 accessions constructed from the set of 388 cultivars.

The coefficient of variation compares the relative amount of variability between crop traits, and it is an excellent indicator of the exploitable variability for breeders. It is remarkable that high values were found in this work for many traits, especially those related to the yield and its components, as well as for other traits related to flowering and earliness. This high source of variability can be employed to develop varieties with very different characteristics, adapted to different environments, and also tailored to market preferences, in both groups of cultivars, with whitish and brown seeds, which are the most economically interesting groups. The accessions studied in this work were tested for their adaptation to abiotic stresses. Some of them showed good behavior under stress conditions. The results are being analyzed, and a manuscript is in preparation. Those data, together with the morphological description reported here, will help breeders select the most promising accessions to be used in breeding programs. The germplasm employed in this work is available upon request in the vegetable gene bank of the COMAV of the Polytechnic University of Valencia. 
Author Contributions: Conceptualization, M.J.D. and M.B.; Methodology, S.A. and L.Y.; Software, J.T.; Validation, M.J.D. and O.V.; Formal Analysis, E.S.; Investigation, S.A. and J.T.; Resources, M.J.D. and O.V.; Data Curation, E.M.; Writing-Original Draft Preparation, S.A.; Writing-Review \& Editing, M.B., M.J.D. and O.V.; Visualization, J.T.; Supervision, M.B.; Project Administration, O.V.; Funding Acquisition, M.J.D. and O.V.

Funding: This research was funded by the Spanish "Ministerio de Economía, Industria y Competitividad", grant number RFP2015-00013-00-00.

Conflicts of Interest: The authors declare no conflict of interest. The funders had no role in the design of the study; in the collection, analyses, or interpretation of data; in the writing of the manuscript, and in the decision to publish the results. 


\section{References}

Al Hassan M., Morosan M., López-Gresa M.P., Prohens J., Vicente O., Boscaiu M. (2016). Salinity-induced variation in biochemical markers provides insight into the mechanisms of salt tolerance in common (Phaseolus vulgaris) and runner ( $P$. coccineus) beans. Int. J. Mol. Sci., 17, 1582.

Arteaga S., Al Hassan M. Wijesinghe C., Yabor L., Llinares J., Boscaiu M., Vicente O. (2018). Screening for Salt Tolerance in Four Local Varieties of Phaseolus Iunatus from Spain. Agriculture, 8, 201.

Beebe, S.; Rao, I.; Blair, M.; Acosta-Gallegos, J. (2013). Phenotyping common beans for adaptation to drought. Front. Physiol., 4, 35.

Beebe S.E., Skroch P.W., Tohme J., Duque E., Pedraza M.C., Nienhuis F. (2000). Structure of genetic diversity among common bean landraces of Middle American origin based on correspondence analysis of RAPD. Crop Sci., 40, 257-272.

Bitocchi E., Nanni L., Bellucci E., Rossi M., Giardini A., Zeuli P.S., Logozzo G., Stougaard J., McClean P., Attene G. (2012). Mesoamerican origin of the common bean (Phaseolus vulgaris L.) is revealed by sequence data. Proc. Natl. Acad. Sci. USA, 109, E788-E796.

Boyer, J. (1982). Plant productivity and environment. Science, 218, 443-448.

Brucher O.B., Brucher H. (1976). The South American wild bean (Phaseolus aborigeneus Burk.) as ancestor of the common bean. Econ. Bot., 30, 257-272.

Cramer W., Guiot J., Fader M., Garrabou J., Gatusso J.P., Iglesias A., Lange M.A., Lionello P., Llasat M.C., Paz S., et al. (2018). Climate change and interconnected risks to sustainable development in the Mediterranean. Nat. Clim. Chang,, 8, 972-989.

Debouck D.G., Smartt J. (1995). Bean. In Evolution of Crop Plants, 2nd ed.; Smartt, J., Simmonds, N.W., Eds.; Longman Scientific and Technical: Harlow, UK, pp. 287296.

Duran L.A., Blair M.W., Giraldo M.C., Macchiavelli R., Prophete E., Nin J.C., Beaver J.S. (2005). Morphological and molecular characterization of common bean landraces and cultivars from the Caribbean. Crop Sci., 45, 1320-1328.

Escribano M., Santalla M., Casquero, P., De Ron A. (1998). Patterns of genetic diversity in landraces of common bean (Phaseolus vulgaris L.) from Galicia. Plant Breed. 117, 49-56.

Escribano, M., De Ron A., Amurrio, J. (1994). Diversity in agronomical traits in common bean populaltions from northwestern Spain. Euphytica, 76, 1-6.

Felsenstein J. (1973). Numerical Taxonomy; W.H. Freeman \& Company: San Francisco, CA, USA.

Fita A., Rodriguez-Burruezo A., Boscaiu M., Prohens J., Vicente O. (2016). Breeding and domesticating crops adapted to drought and salinity: A new paradigm for increasing food production. Front. Plant Sci., 6, 978. 
Food and Agriculture Organization of the United Nations (FAO). (2019). FAOSTAT. Available online: http://faostat3.fao.org/browse/Q/QC/S (accessed on 10 January 2019).

Gepts P., Debouck D.G. (1991). Origen. Domestication and evolution of the common bean (Phaseolus vulgaris L.). In: Schoonhoven, A. Van and Voyset, O. (Eds.). Common bean research for crop improvement. CAB. International. 7-53 p.'

Gepts P. (1990). Biochemical evidence bearing on the domestication of Phaseolus (Fabaceae) beans. Econ. Bot., 44, 28-38.

Gil J., De Ron A. (1992). Variation in Phaseolus vulgaris in the Northwest of the Iberian Peninsula. Plant Breed., 109, 313-319

IBPGR. (1982). Phaseolus vulgaris Descriptors. In Plant Production and Protection Division; FAO: Rome, Italy; p. 32.

Hosfield G., Uebersax M., Isleb T. (1984). Seasonal and genotypic effects on yield and physico-chemical seed characteristics related to food quality $n$ dry, edible beans. J. Am. Soc. Hort. Sci., 109, 182-189.

Koenig R., Gepts P. (1989) Allozyme diversity in wild Phaseolus vulgaris: further evidence for two major centers of diversity. Theor App/ Genet 78:809-81 7.

Lioi L., Piergiovanni A.R. (2013). European common bean. In Genetic and Genomic Resources of Grain Legume Improvement; Singh, M., Upadhyaya, H.D., Bisht, I.S., Eds.; Elsevier: Amsterdam, The Netherlands, pp. 11-40.

Mantel N. (1967). The detection of disease clustering and generalized regression approach. Cancer Res., 27, 209-220.

Mohammadin S.A., Prasanna B.M. (2003). Analysis of genetic diversity in crop plants-Salient statistical tools and considerations. Crop Sci., 43, 1235-1248.

Morosan M., Al Hassan M., Naranjo M., Lopez-Gresa M.P., Vicente O. (2017). Comparative analysis of drought responses in Phaseolus vulgaris (common bean) and $P$. coccineus (runner bean) cultivar. EuroBiotech J., 1, 247-252.

Nienhuis J., Singh S. (1986). Combining ability analyses and relationships among yield, yield components and architectural traits in dry bean. Crop Sci., 26, 21 27.

Ortwin-Sauer C. (1966). The Early Spanish Men; University of California Press: Berkeley, CA, USA.

Perez-Vega E., Campa A., De la Rosa L., Giraldez R., Ferreira J. (2009). Genetic Diversity in a Core Collection Established from the Main Bean Genebank in Spain. Crop Sci., 49, 1377-1386.

Pinheiro C., Baeta J.P., Pereira A.M., Dominguez, H., Ricardo C. (2007). Mineral elements correlations in a Portugese germplasm collection of Phaseolus vulgaris. Integrating Legume Biology for Sustainable Agricultura. In Proceedings of the 6th European Conference on Grain Legumes, Lisbon, Portugal, pp. 125-126. 
Rodiño P., Santalla M., De Ron A., Singh S. (2003). A core collection of common bean from the Iberian peninsula. Euphytica, 131, 165-175.

Rodrigo-Miguez A.P. (2000). Caracterización Morfoagronómica y Bioquímica de Judía Común (Phaseolus Vulgaris L.) de España. Ph.D. Thesis, Universidad de Santiago de Compostela, Santiago, Spain.

Rosales M., Rodriguez-Valentin R., Olvera-Carrillo Y., Acosta-Gallegos J., Covarrubias A. (2012). Physiological analysis of common bean (Phaseolus vulgaris L.) cultivars uncovers characteristics related to terminal drought resistance. Plant Physiol. Biochem., 56, 24-34.

Santalla M., Rodiño A.P., De Ron A.M. (2002). Allozyme evidence supporting southwestern Europe as a secondary center of genetic diversity for common bean. Theor. Appl. Genet., 104, 934-944.

Santos M., Ribeiro R.M.E., Pimentel C. (2009). Photosynthetic parameters and leaf water potential of five common bean genotypes under mild water deficit. Biol. Plant., 53, 229-236.

Sills G., Nienhuis J. (1993). Field plot technique affects snap bean yield evaluation. J. Am. Soc. Hortic. Sci., 188, 672-674.

Singh S.P., Gepts P., Debouck D.G. (1991) Races of common bean (Phaseolus vulgaris, Fabaceae). Econ Bot 45:379-396.

Singh S. (1982). A key for identification of different growth habits of Phaseolus vulgaris L. Annu. Rep. Bean Improv. Coop., 25, 92-94.

Tohme, J., Gonzalez D.O., Beebe S., Duque M. (1996). AFLP analysis of gene pools of a wild bean core collection. Crop Sci., 36, 1375-1384.

Vaid K., Gupta V., Singh R. (1985). Stability analysis in dry bean. Crop Improv., 12, 28-31. 
Subcapitulo 3.3. The use of proline in screening for tolerance to drought and salinity in common bean (Phaseolus vulgaris L.) genotypes

Reference:

Arteaga Sugenith, Yabor Lourdes, Díez María José, Prohens Jaime, Boscaiu Mónica, Vicente Óscar. $\quad$ (2020). $\quad$ Agronomy, 10(6), 817 ; https://doi.org/10.3390/agronomy10060817 
The use of proline in screening for tolerance to drought and salinity in common bean (Phaseolus vulgaris L.) genotypes

Abstract: The selection of stress-resistant cultivars, to be used in breeding programmes aimed at enhancing the drought and salt tolerance of our major crops, is an urgent need for agriculture in a climate change scenario. In the present study, the responses to water deficit and salt stress treatments, regarding growth inhibition and leaf proline (Pro) contents, were analysed in 47 Phaseolus vulgaris genotypes of different origins. A two-way analysis of variance (ANOVA), Pearson moment correlations and principal component analyses (PCAs) were performed on all measured traits, to assess the general responses to stress of the investigated genotypes. For most analysed growth variables and Pro, the effects of cultivar, treatment and their interactions were highly significant $(p<0.001)$; the root morphological traits, stem diameter and the number of leaves were mostly due to uncontrolled variation, whereas the variation of fresh weight and water content of stems and leaves was clearly induced by stress. Under our experimental conditions, the average effects of salt stress on plant growth were relatively weaker than those of water deficit. In both cases, however, growth inhibition was mostly reflected in the stress-induced reduction of fresh weight and water contents of stems and leaves. Pro, on the other hand, was the only variable showing a negative correlation with all growth parameters, but particularly with those of stems and leaves mentioned above, as indicated by the Pearson correlation coefficients and the loading plots of the PCAs. Therefore, in common beans, higher stress-induced accumulation of Pro is unequivocally associated with a stronger inhibition of growth; that is, with a higher sensitivity to stress of the corresponding cultivar. We propose the use of Pro as a suitable biochemical marker for simple, rapid, large-scale screenings of bean genotypes, to exclude the most sensitive, those accumulating higher Pro concentrations in response to water or salt stress treatments. 
Keywords: abiotic stress biomarkers; bean landraces; osmolytes; plant breeding; salt stress; salt stress tolerance; water deficit; water stress tolerance.

\subsubsection{Introduction}

Drought and soil salinity are amongst the most restrictive environmental factors affecting agriculture worldwide. Even moderate degrees of water deficit or salt stress can lead to a reduction of $50-70 \%$ in average yields in most crops when compared with registered record yields (Mantri et al., 2012; Zörb et al., 2019; Osakabe et al., 2014). Drought, brought about by the scarcity of rain, affects more than half of the agricultural land of our planet and is often linked to secondary salinisation of farmland due to intensive irrigation (Fita et al., 2015; Shahid et al., 2018). Cropland salinisation is becoming one of the major constrains for agriculture in many parts of the world, especially in arid and semi-arid regions. At the beginning of this century, it was estimated that around $20 \%$ of the irrigated lands were salinised (Flowers and Flowers, 2005), but this figure is increasing yearly, mainly due to anthropogenic alterations, such as irrigation with brackish water or the abusive and indiscriminate use of chemical fertilizers (Fita et al., 2015). On the other hand, the scarcity of good-quality water for irrigation, mainly as a consequence of the effects of global warming, will mean more-significant crop losses in the near future, which will especially affect subsistence agriculture in developing countries (Morton, 2007). Legumes are some of the most important crops, representing a significant component of the human diet. Globally, legumes complement cereal crops as the main sources of plant minerals and proteins (Belluci et al., 2014). Among the leguminous crops, Phaseolus L. is a large and diverse genus comprising about 70 American species (Freytag and Debouck, 2002), five of which have been domesticated (Phaseolus vulgaris L., Phaseolus dumosus Macfady, Phaseolus coccineus L., Phaseolus acutifolius A. Gray and Phaseolus lunatus L); moreover, a few additional species show signs of incipient domestication (Delgado-Salinas et al., 2006). 
The common bean ( $P$. vulgaris) is the most-consumed legume in human nutrition; it is an essential component of the diet, especially in developing countries, as a source of proteins, vitamins, minerals and fibre (Belluci et al., 2014; Broughton et al., 2003). The species has a natural distribution area from northern Mexico to northwestern Argentina. It was domesticated independently in Central America and the Andes (Gepts and Debouck, 1991), but now it is cultivated practically all over the world. Beans from both origins were introduced to Spain in the 16th century (OrtwinSauer, 1966; Brücher and Brücher, 1976; Debouck, 1995), where they had to adapt to the new environmental conditions, which were very different from those in their native areas. The cropping system in small farms, spread in proximal areas, allowed the genetic flow between genotypes of Mesoamerican and Andean origin (Arteaga et al., 2019). Due to centuries of bean cultivation, the Iberian Peninsula has become a secondary centre of diversification of this species (Pinheiro et al., 2007).

Phaseolus vulgaris is not considered as very tolerant to water stress (Molina et al., 2001); nevertheless, it is cultivated under diverse environmental conditions, including relatively dry areas (Graham and Ranalli, 1997; Singh, 2007). In fact, globally, only a small percentage, around $7 \%$, of the cropland planted with common bean receives adequate rainfall (Broughton, 2003), and in some areas, drought causes yield losses of up to $80 \%$ (Cuellar-Ortiz et al., 2008) Like practically all cultivated plants, the bean is a glycophyte, sensitive to soil salinity even at electric conductivity values below $2 \mathrm{dS} \cdot \mathrm{m}^{-1}$ (Maas and Hoffman, 1977). However, just as there are cultivars that are more resistant to water stress, some respond better to high soil salinity (Gama et al., 2007; Zhumabayeva, 2019).

As for other common crops, many bean genotypes no longer grown in the fields or cultivated only locally at a small scale (landraces, local varieties, heirlooms or minor commercial cultivars) are available from small farmers or germplasm banks and represent a rich source of genetic variability. Landraces appeared over time due 
to selection of traits specifically adapted to local conditions, often suboptimal or even highly stressful. Therefore, such genotypes are probably more competitive in lowinput agriculture and represent a source of allelic richness that may enhance agronomic production under the foreseeable restrictive conditions imposed by climate change (Fess et al., 2011). There is an increasing interest for the recovery of local landraces by consumers and markets, not only concerning global warming but also because of the commercial demand for local products, considered as tastier and healthier (Hurtado et al., 2014). Unfortunately, many autochthonous varieties have been lost, and many others are at risk of extinction, due to genetic erosion. Screening this type of varieties for tolerance to stresses represents an interesting strategic path for the agriculture of the future.

The screening of a large number of genotypes would be greatly facilitated by identifying a suitable stress biomarker, easily quantified by simple, rapid and nondestructive assays, and unequivocally associated to the relative resistance of the cultivars to water deficit or salt stress. Proline (Pro), one of the commonest plant osmolytes (Szabados and Savouré, 2010; Verslues and Sharma, 2010), could be an appropriate candidate because a significant increase in Pro contents in response to water deficit, high salinity or other stressful conditions has been detected in beansas in many other species. However, it is not yet clear whether Pro accumulation in $P$. vulgaris is associated with enhanced or reduced tolerance to stress since contradictory results are available in the literature. Some reports correlated higher Pro contents with a relatively higher stress tolerance when comparing different bean cultivars (Kapuya et al., 1985; Misra and Gupta, 2005; Cardenas-Avila, 2006; Kaymakonova et al., 2008, Herrera-Flores et al., 2012; Ghanbari, 2013), whereas in other cases higher Pro concentrations were measured in the relatively more stresssensitive cultivars (Jiménez-Bremont et al., 2006; Al Hassan et al., 2016; Morosan et al., Morosan). All these studies were based on the comparison of a few genotypes. 
Only a wider analysis, based on a considerably higher number of cultivars, grown under the same experimental conditions and subjected to the same stress treatments, could establish whether responses to stress based on Pro accumulation are relevant, or not, for stress tolerance in P. vulgaris, and how Pro could be used as a reliable abiotic stress biomarker in this species.

Based on the ideas mentioned above, we have applied specific water deficit and salt stress treatments, under controlled greenhouse conditions, to a relatively large number of common bean cultivars, obtained from germplasm banks. The aims of this study were (i) to determine the overall response of the analysed genotypes to controlled water and salt stress treatments, (ii) to establish the role of Pro in bean stress responses, either as a mere stress biomarker or as an osmolyte directly involved on stress tolerance mechanisms and (iii) based on the results obtained, to propose Pro as a suitable biochemical marker for the rapid selection of bean cultivars with a (relatively) higher tolerance (or sensitivity) to drought or salinity.

\section{Plant Material}

The study included 47 accessions of common bean (P. vulgaris), from Spain (23), Colombia (19) and Cuba (5), provided by the Germplasm Bank of Universitat Politècnica de València (UPV), the International Center for Tropical Agriculture (CIAT) and the Bioplants Center, University of Ciego de Ávila, respectively. Spanish genotypes are represented by local landraces, with geographic origins indicated in Table 11. Materials from Cuba are commercial varieties or experimental lines from INIFAT (Alexander Humboldt Institute for Basic Research in Tropical Agriculture) or IIHDL (Liliana Dimitrova Horticultural Research Institute, La Habana, Cuba), and those from Colombia are lines reported to be relatively resistant to drought and high temperatures. 
Table 11 . Origin of the analysed Phaseolus vulgaris accessions and duration of the applied stress treatments.

\begin{tabular}{|c|c|c|c|c|c|}
\hline Abbr. & $\begin{array}{c}\text { Treat } \\
\text { ment } \\
\text { (weeks) }\end{array}$ & $\begin{array}{l}\text { Genebank } \\
\text { code }\end{array}$ & Country & Origin & Cultivar name \\
\hline Sp 1 & 2 & BGV000143 & Spain & Lecina, Huesca & $\begin{array}{l}\text { Judía amarilla } \\
\text { de enrame }\end{array}$ \\
\hline Sp 2 & 2 & BGV001191 & Spain & Velez Rubio, Almería & Judía \\
\hline Sp 3 & 2 & BGV001581 & Spain & Mercado el Olivar, Palma de Mallorca & Judia de careta \\
\hline Sp 4 & 2 & BGV003176 & Spain & Barlovento, Santa Cruz de Tenerife & $\begin{array}{l}\text { Judia blanca } \\
\text { mantecosa }\end{array}$ \\
\hline Sp 5 & 2 & BGV003616 & Spain & La Bañeza, León & \\
\hline Sp 6 & 2 & BGV003941 & Spain & AldeaNueva de Barbarroya, Toledo & Judía larguilla \\
\hline Sp 7 & 2 & BGV004159 & Spain & Plascencia, Cáceres & \\
\hline Sp 8 & 2 & BGV011254 & Spain & Las Presillas, Puente Viesgo, Cantabria & Garrafal oro \\
\hline Sp 9 & 2 & BGV013605 & Spain & Campo, Huesca & Negra \\
\hline Co 10 & 2 & INB-39 & Colombia & - & \\
\hline Co 11 & 2 & INB-40 & Colombia & - & \\
\hline Co 12 & 2 & INB-42 & Colombia & - & \\
\hline Co 13 & 2 & INB-43 & Colombia & - & \\
\hline Co 14 & 2 & INB-48 & Colombia & - & \\
\hline Co 15 & 2 & |NB-48| & Colombia & - & \\
\hline Cu 16 & 2 & V-71 & Cuba & INIFAT & Bolita 11a \\
\hline Cu 17 & 2 & $\mathrm{E}-125$ & Cuba & IIHLD & $E-125 b$ \\
\hline Cu 18 & 2 & Milagro VIII & Cuba & INIFAT & Milagro Villareñoa \\
\hline Sp 19 & 3 & BGV001167 & Spain & Chirivel, Almeria & Judia \\
\hline Sp 20 & 3 & BGV001169 & Spain & Laujar de Andarax, Almeria & Judia mocha \\
\hline Sp 21 & 3 & BGV001182 & Spain & Juviles, Granada & Alubias \\
\hline Sp 22 & 3 & BGV003610 & Spain & Ponferrada, León & \\
\hline Sp 23 & 3 & BGV003614 & Spain & La Bañeza, León & \\
\hline Sp 24 & 3 & BGV003618 & Spain & La Bañeza, León & \\
\hline Sp 25 & 3 & BGV004161 & Spain & Plasencia, Cáceres & \\
\hline Sp 26 & 3 & BGV004466 & Spain & Bilbao, Vizcaya & Alubias pintas \\
\hline Sp 27 & 3 & BGV011235 & Spain & Beranga, Hazas de Cesto, Cantabria & Carica \\
\hline Sp 28 & 3 & BGV013603 & Spain & Beceite, Teruel & Judia de Franco \\
\hline Sp 29 & 3 & BGV013609 & Spain & Centenero, Huesca & Judia Fartapobres \\
\hline Sp 30 & 3 & BGV014980 & Spain & Alcorisa, Teruel & De tabilla ancha \\
\hline Sp 31 & 3 & BGV015856 & Spain & Alicante & Habichuela del barco \\
\hline
\end{tabular}




\begin{tabular}{|c|c|c|c|c|c|}
\hline Sp 32 & 3 & BGV015859 & Spain & Albarracín & Judia \\
\hline Co 33 & 3 & ALB-74 & Colombia & - & \\
\hline Co 34 & 3 & INB-35 & Colombia & - & \\
\hline Co 35 & 3 & INB-38 & Colombia & - & \\
\hline Co 36 & 3 & INB-41 & Colombia & - & \\
\hline Co 37 & 3 & INB-44 & Colombia & - & \\
\hline Co 38 & 3 & INB-45 & Colombia & - & \\
\hline Co 39 & 3 & INB-46 & Colombia & - & \\
\hline Co 40 & 3 & INB-47 & Colombia & - & \\
\hline Co 41 & 3 & SEF-9 & Colombia & - & \\
\hline Co 42 & 3 & SEF-52 & Colombia & - & \\
\hline Co 43 & 3 & SEF-53 & Colombia & - & \\
\hline Co 44 & 3 & SEF-55 & Colombia & - & \\
\hline Co 45 & 3 & SEF-56 & Colombia & - & \\
\hline Cu 46 & 3 & $V-13$ & Cuba & INIFAT & P 2240b \\
\hline Cu 47 & 3 & V-51 & Cuba & INIFAT & P 186b \\
\hline
\end{tabular}

\section{Plant Growth and Stress Treatments}

The plants were obtained by seed germination. Several seeds of each genotype were germinated in trays with peat, perlite and vermiculite $(2: 1: 1)$. When the first trifoliate true leaves were formed, the seedlings were transplanted to individual 1.6 L-pots with the same substrate in the greenhouse; Hoagland's nutrient solution (Hoagland and Arnon, 1950) was used for irrigation. When the plants reached a height of at least $20 \mathrm{~cm}$ and had two to five true leaves, plants were selected for the treatments and placed in $55 \times 40 \mathrm{~cm}$ plastic trays $(10$ pots per tray). Irrigation was performed twice a week by adding to each tray $1.5 \mathrm{~L}$ deionised water or a $150 \mathrm{mM}$ $\mathrm{NaCl}$ solution, for the control and salt stress treatments, respectively. The water stress treatment was applied by completely withholding irrigation of the plants. Five individual plants (biological replicas) of each genotype were used per treatment. Treatments were stopped after two weeks for 18 genotypes when plants showed clear wilting and general decline symptoms in the water deficit treatment, but before plant mortality was observed; salt treatments of these cultivars were stopped at the same 
time. The remaining, relatively more resistant 29 genotypes were treated for an additional week. The two groups of plants were analysed independently. All treatments were carried out under controlled conditions in the greenhouse: long-day photoperiod (16 h of light), temperature set at $23 \circ \mathrm{C}$ during the day and $17 \circ \mathrm{C}$ at night. Once the treatments were finished, whole plants were harvested, collecting separately their roots, stems and leaves. Several growth parameters were measured in all plants: the diameter of the stem (SD), the length of the roots (RL) and stems $(\mathrm{SL})$, the number of trifoliate leaves (Lno) and the fresh weight of roots (RFW), stems (SFW) and leaves (LFW).

Part of the fresh material of roots, stems and leaves was weighed (FW), placed at $65 \circ \mathrm{C}$ in an oven for three days, and weighed again to determine the dry weight (DW). The water content percentage (WC\%) of the three organs was calculated according to the formula:

$$
\mathrm{WC}(\%)=[(\mathrm{FW}-\mathrm{DW}) / \mathrm{FW}] \times 100(1)
$$

\section{Quantification of Proline Contents}

Leaf Pro concentrations were quantified using dry plant material, according to the ninhydrin-acetic acid method (Bates et a., 1973). Pro was extracted in a $3 \%(w / v)$ aqueous sulfosalicylic acid solution; the sample was mixed with the acid ninhydrin solution, incubated for $1 \mathrm{~h}$ at $95^{\circ} \mathrm{C}$, cooled on ice and extracted with toluene. Samples with known Pro amounts were assayed in parallel to obtain a standard curve. The absorbance of the supernatants was read at $520 \mathrm{~nm}$ using toluene as a blank. Pro concentration was finally expressed as $\mu \mathrm{mol} \mathrm{g}^{-1} \mathrm{DW}$.

\section{Statistical Analysis}

Plants from the two- and three-week treatments were analysed separately. A two-way analysis of variance (ANOVA) was performed for all determined traits, to check the effects of the 'cultivar' and 'treatment' factors, and the interaction between treatment and genotype. Pearson moment correlations were also performed for all 
measured parameters, and a principal component analysis (PCA) was used to check the similarity between the responses to the different types of stress within each cultivar, and the similarity between accessions. Data were analysed using Statgraphics Centurion v.16 software (Statpoint Technologies, Warrenton, VA, USA).

\subsubsection{Results}

\section{Analysis of Variance of Registered Traits}

Some cultivars (18) were apparently more sensitive to both salt and water stress and therefore treatments were stopped after two weeks. For the remaining genotypes (29), treatments were extended to three weeks (Table 11). All growth parameters and the leaf Pro concentration of control and stressed plants, for each cultivar, are summarised in Supplementary Table S1. Notwithstanding quantitative differences between genotypes, the overall picture is that plants of most cultivars were affected by both types of stress, water deficit and salinity, which inhibited growth as indicated by the general relative reduction observed in the measured morphological variables. Under the specific stress conditions applied in the experiments, in most cases, growth inhibition was more accentuated in the waterstressed plants than in the salt-stressed ones. Again, for most cultivars, leaf Pro contents increased significantly in response to both types of stress. To assess the general responses to stress of the selected cultivars, a two-way ANOVA was performed considering the effect on each parameter of cultivar and treatment, and their interaction (Table 12).

For most analysed variables, the effects of cultivar, treatment and their interactions were highly significant $(p<0.001)$. The only non-significant value was found in the two-week treatment and the trait 'root length', for the interaction cultivar $\times$ treatment. In plants subjected to the two-week treatment, relatively stronger contributions to the sum of squares were those of 'cultivar' for the variables root fresh weight (RFW) and stem length (SL), and 'treatment' for root water content 
(RWC), stem fresh weight (SFW), leaf fresh weight (LFW) and leaf water content (LWC). For stem water content (SWC) and Pro, both factors, cultivar and treatment, contributed similarly to the sum of squares (SS). On the other hand, most of the variation observed for root length (RL), and stem diameter (SD) was due to uncontrolled variation, as shown by the higher SS percentage of the residual (Table 12;Error! No se encuentra el origen de la referencia.).

Table 12. Two-way analysis of variance (ANOVA) of cultivar, treatment and their interactions for the parameters considered. Numbers represent percentages of the sum of squares at the $5 \%$ confidence level. Abbreviations

\begin{tabular}{ccccccccc}
\hline \multirow{2}{*}{ Trait } & \multicolumn{9}{c}{ Two weeks } & \multicolumn{3}{c}{ Three weeks } \\
\cline { 2 - 9 } RL & Cultivar & Treatment & Interaction & Residual & Cultivar & Treatment & Interaction & Residual \\
RFW & $22.14 * * *$ & $18.42 * * *$ & $9.24 \mathrm{~ns}$ & 50.19 & $32.90 * * *$ & $10.43 * * *$ & $21.52 * * *$ & 35.16 \\
RWC & $4.34 * * *$ & $70.52 * * *$ & $14.75 * * *$ & 10.39 & $22.23 * * *$ & $52.05 * * *$ & $13.58 * * *$ & 12.15 \\
SD & $24.77 * * *$ & $27.08 * * *$ & $13.15 * * *$ & 35.00 & $14.17 * * *$ & $1.06 * *$ & $23.61 * * *$ & 61.16 \\
SL & $52.63 * * *$ & $11.77 * * *$ & $9.85 * * *$ & 25.76 & $42.71 * * *$ & $18.30 * * *$ & $18.17 * * *$ & 20.81 \\
SFW & $19.51 * * *$ & $47.29 * * *$ & $13.84 * * *$ & 19.36 & $26.50 * * *$ & $38.21 * * *$ & $15.10 * * *$ & 20.19 \\
SWC & $30.07 * * *$ & $33.12 * * *$ & $16.07 * * *$ & 20.74 & $31.64 * * *$ & $21.15 * * *$ & $32.13 * * *$ & 15.08 \\
Lno & $24.67 * * *$ & $32.12 * * *$ & $10.16 * * *$ & 33.05 & $14.69 * * *$ & $9.06 * * *$ & $21.14 * * *$ & 55.12 \\
LFW & $15.70 * * *$ & $53.55 * * *$ & $16.85 * * *$ & 13.89 & $32.54 * * *$ & $32.42 * * *$ & $23.8 * * *$ & 11.24 \\
LWC & $25.53 * * *$ & $37.59 * * *$ & $14.52 * * *$ & 22.36 & $32.50 * * *$ & $24.36 * * *$ & $20.21 * * *$ & 22.93 \\
Pro & $30.46 * * *$ & $28.92 * * *$ & $18.89 * * *$ & 21.72 & $40.52 * * *$ & $20.08 * * *$ & $15.61 * * *$ & 23.79 \\
\hline
\end{tabular}

Note: Abbreviations: RL, root length; RFW, root fresh weight; RWC, root water content; SD, stem diameter; SL, stem length; SFW, stem fresh weight; SWC, stem water content; Lno, leaf number; LFW, leaf fresh weight; LWC, leaf water content; Pro, proline content. Asterisks indicate the degree of significance: $* \mathrm{p}<0.05 ;{ }^{* *} \mathrm{p}<0.01 ;{ }^{* * *} \mathrm{p}<0.001$, ns = not significant.

The ANOVA of data obtained from the three-weeks-treated plants showed somewhat different results. The effect of 'cultivar' was the most substantial contributor to SS for the variables SL, LWC and Pro, and that of 'treatment' for RWC and SFW. The relative contributions of cultivar and treatment were similar for LFW, and those of cultivar and the interaction of both factors, for SWC. The most-significant contribution to variation of RL, RFW, SD and the number of leaves (Lno) is accounted for by the residual source of variation. 
Disregarding the individual responses to water and salt stress of the selected bean genotypes, which vary quantitatively (Table S1), a general analysis was performed, including all cultivars and using the mean values calculated for all measured growth variables and Pro contents (¡Error! No se encuentra el origen de la referencia.). After the water stress treatments, either for two or three weeks, all morphological parameters determined in the stressed plants showed a significant decrease with respect to the corresponding values of the well-watered controls. The strongest reductions, down to less than $30 \%$ of the controls, were observed for root and leaf fresh weight. The effect of water deficit was relatively weaker regarding the reduction of root length and stem parameters (SD, SL and SWC), especially in the three-week treatments. Leaf Pro concentration, on the contrary, significantly increased in response to water stress, about 2.7-fold and 2.1-fold, as average, for the plants treated for two and three weeks, respectively (Table 13).

Under the specific conditions of our experiments, salt stress had a smaller effect than water deficit on the average growth inhibition of the bean cultivars, reflected mostly in a sharp reduction $(>70 \%)$ of the leaf fresh weight with respect to the control, followed by that of stem fresh weight (about 50\%). Other parameters, such as root and stem water content, stem diameter or root fresh weight (in the twoweek treatment) did not change significantly or decreased only slightly in response to increased salinity. The mean values calculated for most growth variables were similar for both treatment times. Pro contents also rose significantly, about 2.6-fold over control values, in the salt-treated plants (Table 13). 
Table 13. Mean values and percentages with respect to the control (\%) of traits measured in Phaseolus vulgaris cultivars after two and three weeks of control (C), water stress (WS) (withholding of irrigation) and salt stress (SS) (150 mM NaCl) treatments.

\begin{tabular}{|c|c|c|c|c|c|c|}
\hline \multirow[t]{2}{*}{ Trait } & \multicolumn{3}{|c|}{ Two weeks } & \multicolumn{3}{|c|}{ Three weeks } \\
\hline & $\mathrm{C}$ & WS & SS & $\mathrm{C}$ & WS & SS \\
\hline $\mathrm{RL}(\mathrm{cm})$ & $36.04 \mathrm{c}$ & $23.24 \mathrm{a}$ & $30.39 \mathrm{~b}$ & $29.50 \mathrm{C}$ & $21.14 \mathrm{~A}$ & $25.73 \mathrm{~B}$ \\
\hline$\%$ & & 64.48 & 84.32 & & 71.66 & 87.22 \\
\hline RFW (g) & $3.22 \mathrm{~b}$ & $0.44 \mathrm{a}$ & $3.36 \mathrm{~b}$ & $2.78 \mathrm{C}$ & $0.69 \mathrm{~A}$ & $1.85 \mathrm{~B}$ \\
\hline$\%$ & & 13.66 & 104.35 & & 24.82 & 66.55 \\
\hline RWC (\%) & $85.70 \mathrm{~b}$ & $31.94 \mathrm{a}$ & $82.08 \mathrm{~b}$ & 84.07B & $42.11 \mathrm{~A}$ & $85.28 \mathrm{~B}$ \\
\hline$\%$ & & 37.27 & 95.78 & & 50.09 & 101.44 \\
\hline $\mathrm{SD}(\mathrm{mm})$ & $3.87 \mathrm{c}$ & $2.91 \mathrm{a}$ & $3.55 b$ & $3.89 \mathrm{C}$ & $3.18 \mathrm{~A}$ & $3.45 \mathrm{~B}$ \\
\hline$\%$ & & 75.19 & 91.73 & & 81.75 & 88.69 \\
\hline $\mathrm{SL}(\mathrm{cm})$ & $148.63 b$ & $109.95 \mathrm{a}$ & $115.75 \mathrm{a}$ & 139.90B & $95.43 \mathrm{~A}$ & $90.85 \mathrm{~A}$ \\
\hline$\%$ & & 73.98 & 77.88 & & 68.21 & 64.94 \\
\hline SFW (g) & $10.40 \mathrm{c}$ & $2.82 \mathrm{a}$ & $5.37 \mathrm{~b}$ & $9.00 \mathrm{C}$ & $3.18 \mathrm{~A}$ & 4.63B \\
\hline$\%$ & & 27.12 & 51.63 & & 35.33 & 51.44 \\
\hline SWC (\%) & $82.14 \mathrm{~b}$ & $56.84 \mathrm{a}$ & $78.31 \mathrm{~b}$ & $82.82 \mathrm{~B}$ & $64.06 \mathrm{~A}$ & 79.47B \\
\hline$\%$ & & 69.20 & 95.34 & & 77.35 & 95.96 \\
\hline Lno & $12.43 \mathrm{~b}$ & $6.47 \mathrm{a}$ & $7.42 \mathrm{a}$ & $13.28 \mathrm{~B}$ & $7.35 \mathrm{~A}$ & $7.98 \mathrm{~A}$ \\
\hline$\%$ & & 52.05 & 59.69 & & 55.35 & 60.09 \\
\hline LFW (g) & $22.73 c$ & $2.57 \mathrm{a}$ & $5.94 \mathrm{~b}$ & $18.21 \mathrm{~B}$ & $4.08 \mathrm{~A}$ & $5.40 \mathrm{~A}$ \\
\hline$\%$ & & 11.31 & 26.13 & & 22.41 & 29.65 \\
\hline LWC & $84.04 \mathrm{c}$ & $38.39 \mathrm{a}$ & $58.58 \mathrm{~b}$ & $81.62 \mathrm{C}$ & $49.31 \mathrm{~A}$ & $55.48 \mathrm{~B}$ \\
\hline$\%$ & & 45.68 & 69.70 & & 60.41 & 67.97 \\
\hline Pro $\left(\mu \mathrm{mol} \mathrm{g}{ }^{-1} \mathrm{DW}\right)$ & $31.67 \mathrm{a}$ & $86.61 b$ & $82.74 b$ & $25.89 \mathrm{~A}$ & $53.57 \mathrm{~B}$ & $68.29 \mathrm{C}$ \\
\hline$\%$ & & 273.48 & 261.26 & & 206.91 & 263.77 \\
\hline
\end{tabular}

Note: Abbreviations: RL, root length; RFW, root fresh weight; RWC, root water content; SD, stem diameter; SL, stem length; SFW, stem fresh weight; SWC, stem water content; Lno, leaf number; LFW, leaf fresh weight; LWC, leaf water content; Pro, proline content. Different letters (lowercase for two-week and capital for three-week treatments) indicate significant differences between treatments for each trait, according to the Tukey test, at the 95\% confidence level. 


\section{Correlation Analysis}

Pearson moment correlation between the analysed traits for salt and water stress are presented separately for plants from the two-week (Fig. 15 a) and threeweek (¡Error! No se encuentra el origen de la referencia. b) treatments. Correlations between all morphological variables were in most cases positive, for both stresses and the two treatment times, although the correlation coefficients varied widely, from $r<0.1$ to $r>0.9$. Considering specifically the two-week treatment, the strongest correlations $(r \geq 0.8)$ for the salt stress treatment were found between root water content (RWC) and stem fresh weight (SFW) or water content (SWC); or between SFW, leaf fresh weight (LFW) and the number of leaves (Lno) (Figure $1 \mathrm{a}$ ). Under conditions of water stress, the strongest positive correlations were also found between SFW, LFW and Lno; between water contents of roots, stems and leaves (RWC/SWC/LWC) or between SFW and stem diameter (SD) (Fig. 15 a). On the other hand, Pro contents showed negative correlations with all growth parameters (except for RWC in the salt stress treatment), most significantly with leaf water content, but also with LFW and stem growth parameters (SFW and SWC). Correlations followed a similar pattern for both types of stress but were weaker (lower ' $r$ ' values) in the case of salt stress (Fig. 15a).

Correlations between the different measured variables, generally positive for growth parameters and negative between Pro contents and the rest of variables, were maintained, qualitatively, when comparing the two- and three-week treatments, and for both stresses, but with lower relative significance for the longer treatment time (Fig. 15 b). 
Resultados 
Fig. 15. Heatmap of Pearson moment correlation coefficients ( $r$ ) between the analysed traits in Phaseolus vulgaris cultivars submitted to two weeks (a) and three weeks (b) of water and salt stresses.

\begin{tabular}{|c|c|c|c|c|c|c|c|c|c|c|c|}
\hline & & & & & & Salt st & & & & & \\
\hline & RL & RFW & RWC & SD & SL & SFW & SWC & Lno & LFW & LWC & Pro \\
\hline RL & & 0.01 & 0.24 & 0.63 & 0.50 & 0.46 & 0.29 & 0.46 & 0.45 & 0.36 & -0.16 \\
\hline RFW & 0.50 & & 0.11 & 0.57 & 0.50 & 0.78 & 0.38 & 0.48 & 0.19 & 0.13 & -0.1 \\
\hline RWC & 0.75 & 0.63 & & 0.72 & 0.38 & 0.80 & 0.83 & 0.68 & 0.76 & -0.08 & 0.16 \\
\hline SD & 0.40 & 0.07 & $\mathbf{0 . 0 3}$ & & 0.28 & 0.77 & 0.33 & 0.55 & 0.62 & 0.42 & -0.42 \\
\hline SL & 0.43 & 0.04 & 0.23 & 0.32 & & 0.54 & -0.03 & 0.44 & 0.51 & 0.12 & -0.23 \\
\hline SFW & 0.67 & 0.20 & 0.11 & 0.81 & 0.56 & & 0.41 & 0.84 & 0.89 & 0.56 & -0.54 \\
\hline SWC & 0.62 & 0.57 & -0.29 & 0.70 & 0.20 & 0.72 & & 0.58 & 0.65 & 0.58 & -0.4 \\
\hline $\mathrm{LnO}$ & 0.68 & -0.10 & 0.11 & 0.72 & 0.49 & 0.78 & 0.21 & & 0.79 & 0.46 & -0.41 \\
\hline LFW & 0.63 & 0.76 & 0.18 & 0.71 & 0.56 & 0.92 & 0.40 & 0.81 & & 0.65 & -0.58 \\
\hline LWC & 0.65 & 0.62 & 0.91 & 0.78 & 0.26 & 0.78 & 0.90 & 0.63 & 0.75 & & -0.60 \\
\hline Pro & -0.58 & -0.57 & -0.77 & -0.77 & -0.35 & -0.74 & -0.74 & -0.6 & -0.67 & -0.80 & \\
\hline
\end{tabular}

Water stress

(a)

\begin{tabular}{|c|c|c|c|c|c|c|c|c|c|c|c|}
\hline \multirow[b]{3}{*}{$\mathrm{RL}$} & \multirow[b]{2}{*}{ RL } & \multirow[b]{2}{*}{ RFW } & \multirow[b]{2}{*}{ RWC } & \multirow[b]{2}{*}{$\mathrm{SD}$} & \multicolumn{2}{|c|}{ Salt stress } & \multirow[b]{2}{*}{ SWC } & \multirow[b]{2}{*}{ Lno } & \multirow[b]{2}{*}{ FW } & \multirow[b]{2}{*}{ LWC } & \multirow[b]{2}{*}{ Pro } \\
\hline & & & & & SL & SFW & & & & & \\
\hline & & 0.08 & -0.04 & 0.40 & 0.34 & 0.23 & -0.03 & 0.13 & -0.22 & 0.13 & -0.17 \\
\hline RFW & 0.19 & & 0.14 & 0.26 & 0.32 & 0.48 & 0.12 & 0.21 & 0.50 & 0.24 & -0.15 \\
\hline RWC & 0.45 & 0.39 & & 0.47 & 0.27 & 0.56 & 0.67 & 0.28 & 0.40 & 0.05 & 0.14 \\
\hline SD & 0.11 & 0.15 & -0.09 & & 0.16 & 0.60 & 0.50 & 0.35 & 0.48 & 0.48 & -0.29 \\
\hline $\mathrm{SL}$ & 0.24 & 0.26 & -0.20 & 0.18 & & 0.62 & 0.01 & 0.30 & 0.52 & 0.30 & -0.22 \\
\hline SFW & 0.49 & 0.38 & -0.25 & 0.68 & 0.60 & & 0.34 & 0.59 & 0.85 & 0.54 & -0.34 \\
\hline SWC & 0.43 & 0.27 & -0.25 & 0.60 & 0.18 & 0.55 & & 0.27 & 0.44 & 0.72 & -0.31 \\
\hline $\mathrm{LnO}$ & 0.26 & 0.13 & -0.09 & 0.41 & 0.31 & 0.58 & 0.20 & & 0.48 & 0.33 & -0.18 \\
\hline LFW & 0.37 & 0.58 & -0.24 & 0.58 & 0.51 & 0.86 & 0.36 & 0.50 & & 0.62 & -0.47 \\
\hline LWC & 0.39 & 0.36 & 0.08 & 0.56 & 0.31 & 0.63 & 0.83 & 0.36 & 0.62 & & -0.58 \\
\hline Pro & -0.30 & -0.20 & -0.45 & -0.43 & -0.10 & -0.38 & -0.45 & -0.16 & -0.41 & -0.55 & \\
\hline
\end{tabular}

Water stress

(b)

Note: Dark blue denotes high correlation $(r \rightarrow 1)$, dark red high negative correlation $(r \rightarrow-1)$. Abbreviations: RL, root length; RFW, root fresh weight; RWC, root water content; SD, stem diameter; SL, stem length; SFW, stem fresh weight; SWC, stem water content; Lno, leaf number; LFW, leaf fresh weight; LWC, leaf water content; Pro, proline content. 


\section{Principal Component Analysis (PCA)}

A PCA was performed, separately for the cultivars subjected to the two-week and three-week treatments and including the mean values of all measured parameters and the three applied conditions (control, water stress and salt stress) (Table 14, Fig. 16).

Table 14. Component weights in the PCA performed on cultivars subjected to two and three weeks of treatments.

\begin{tabular}{ccccc}
\hline Trait & Two weeks & \multicolumn{3}{c}{ Three weeks } \\
\hline & Component 1 & Component 2 & Component 1 & Component 2 \\
\hline RL & 0.320 & -0.054 & 0.243 & 0.109 \\
RFW & 0.222 & 0.329 & 0.282 & -0.017 \\
RWC & 0.318 & 0.267 & 0.250 & 0.529 \\
SL & 0.201 & -0.578 & 0.262 & -0.470 \\
SFW & 0.388 & -0.178 & 0.421 & -0.217 \\
SWC & 0.325 & 0.436 & 0.319 & 0.491 \\
Lno & 0.322 & -0.374 & 0.286 & -0.282 \\
LFW & 0.370 & -0.227 & 0.406 & -0.264 \\
LWC & 0.354 & 0.260 & 0.384 & 0.218 \\
Pro & -0.291 & -0.053 & -0.240 & -0.030
\end{tabular}

Note: Abbreviations: RL, root length; RFW, root fresh weight; RWC, root water content; SD, stem diameter; SL, stem length; SFW, stem fresh weight; SWC, stem water content; Lno, leaf number; LFW, leaf fresh weight; LWC, leaf water content; Pro, proline.

The PCA corresponding to the two-week treatments detected two components with Eigenvalues higher than 1, which explained $70.1 \%$ of the total variability of data (56.5\% and $13.6 \%$ for the first and second components, respectively). All growth parameters-most significantly the fresh weights of stems (SFW) and leaves (LFW), followed by the water contents of both organs (LWC and SWC)-were positively correlated with the first component, whereas the only one negatively correlated was Pro concentration in leaves. Regarding the second component, some morphological 
variables (especially SWC and RFW) were positively correlated, whereas for others (e.g., SL or Lno) the correlation was negative (Table 14, Fig. 16a).

Two components with an Eigenvalue higher than one were also detected in the PCA corresponding to the three-week treatments, the first explaining $44.3 \%$ and the second $14.0 \%$ of the total variability; that is, together explaining $58.3 \%$ of the total variation. Correlations of the different variables followed similar patterns to those observed for the cultivars treated for two weeks, for example regarding the negative correlation of Pro with the first component, and the positive correlations of all growth variables, with SFW and LFW showing the highest significance (Table 14, Fig. 16b).

The 18 cultivars from the shorter treatment period (Fig. 17 a) were dispersed onto the two axes of the scatterplot, indicating high variability in the selected genotypes. There was, however, good separation between the different treatments, not only when looking individually at each cultivar, but also considering the overall behaviour of all genotypes. Plants from the control (green symbols) and water stress (pink) treatments were clearly separated, with almost no overlapping between the two conditions. Those symbols (blue) corresponding to the salt stress treatments appear located in the scatterplot in-between the control and water stress samples, which was in agreement with the weaker effect (on average) of the salt treatments as compared to water deficit, under the specific conditions used in our experiments. The scatterplot corresponding to the 29 cultivars that were subjected to the more prolonged (three-week) treatment (Fig. 17 b) showed the same general picture, maybe with more overlapping of the water- and salt-stressed plants. More-significant dispersion of the scores was found, for both treatment times, in the controls indicating a high variability of morphological traits of the different cultivars. Under salt stress, the separation between scores was not so pronounced as under water stress, suggesting a more homogeneous general response of the bean genotypes to salinity than to drought, at least under the conditions of our experiments (Fig. 17). 
Fig. 16. Loading plot of the principal component analysis (PCA) conducted with the analysed traits, in P. vulgaris cultivars subjected to control, water deficit and salt stress treatments.

$\mathrm{a}$

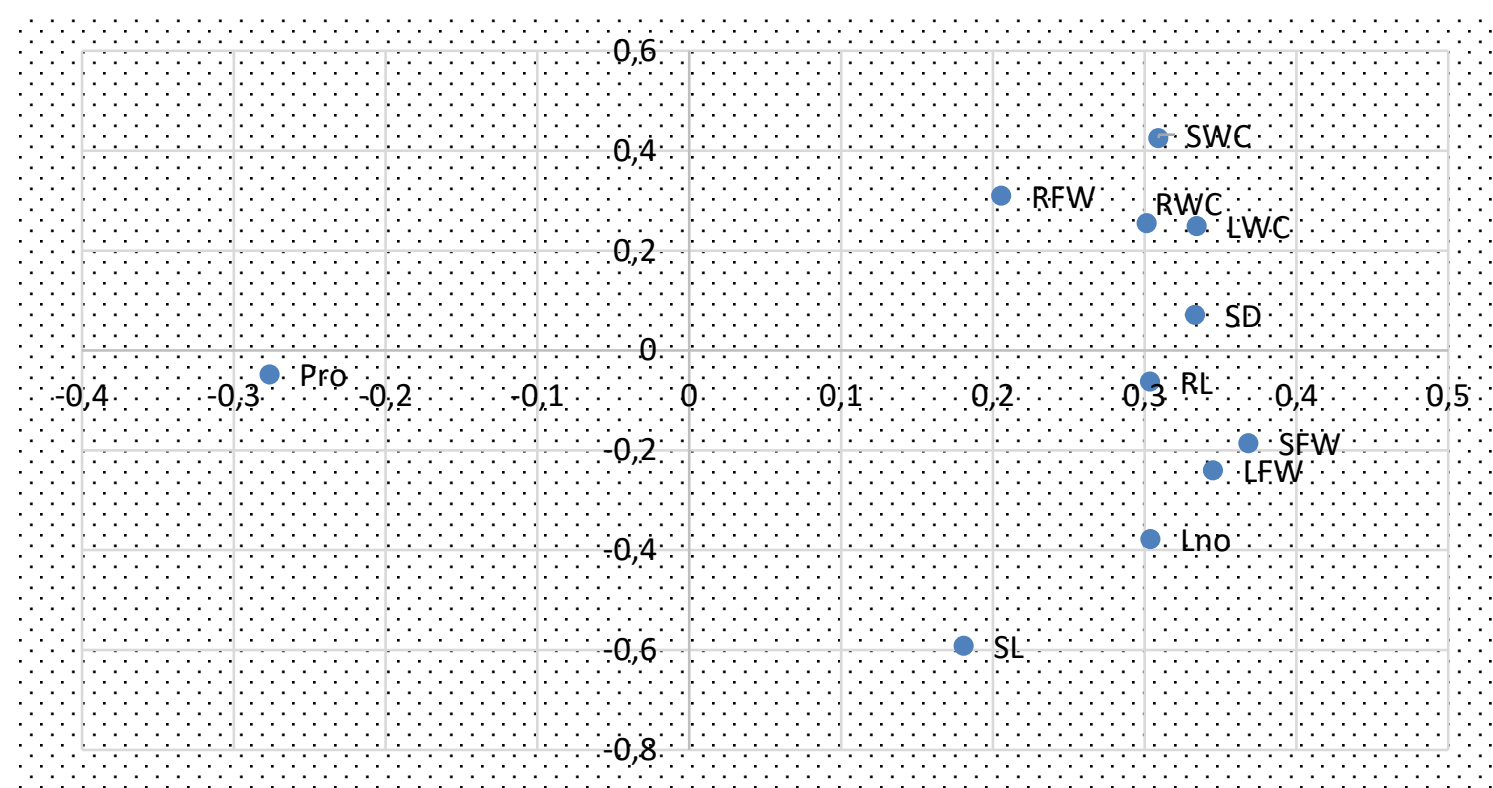

b

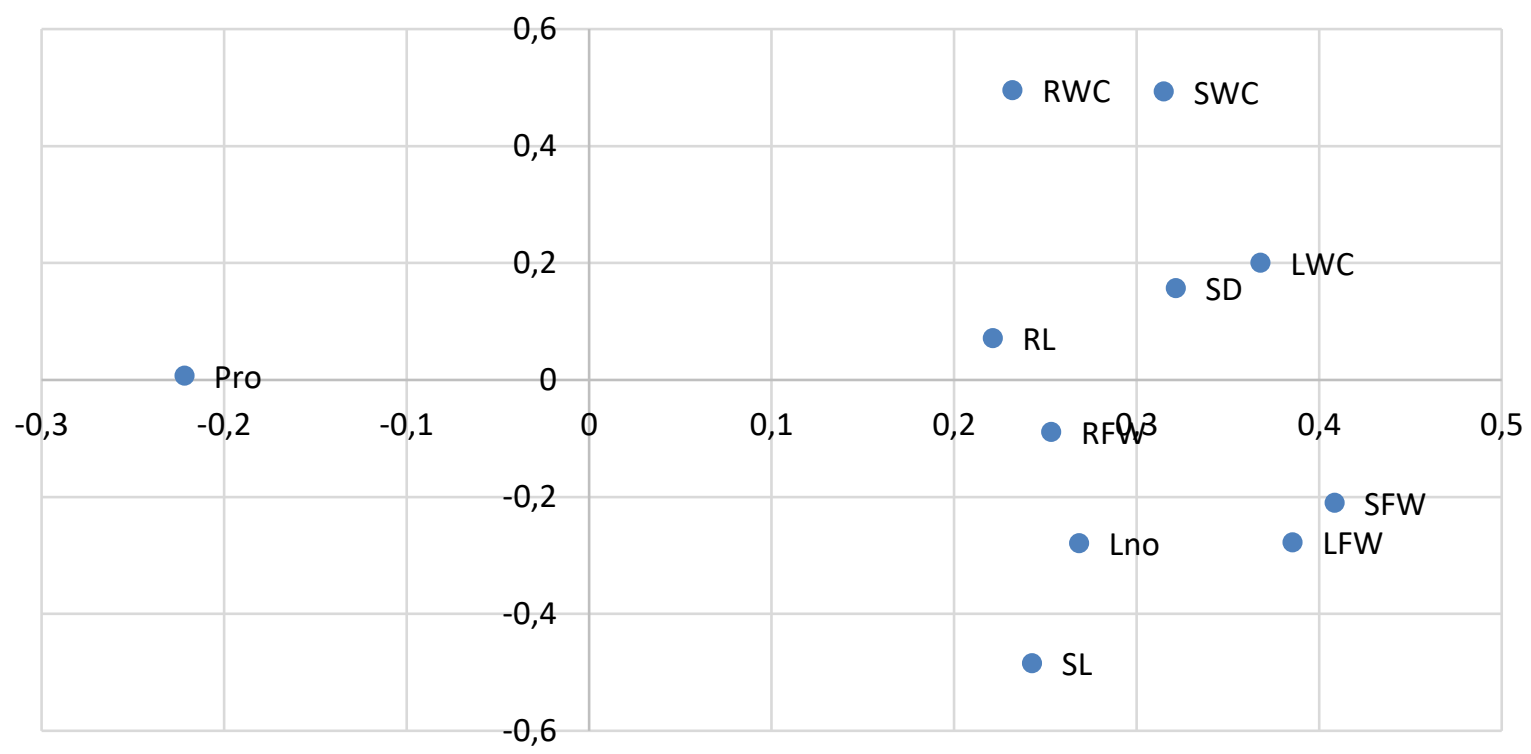

Note: Two-week treatments (a); $56.5 \%$ and $13.6 \%$ of the total variability are explained by the first ( $x$-axis) and the second ( $y$-axis) components, respectively. Three-week treatments (b); $44.3 \%$ and $14.0 \%$ of the total variability are explained by the first (x-axis) and the second ( $y-$ axis) components, respectively. Abbreviations: RL, root length; RFW, root fresh weight; RWC, root water content; SD, stem diameter; SL, stem length; SFW, stem fresh weight; SWC, stem water content; Lno, leaf number; LFW, leaf fresh weight; LWC, leaf water content; Pro, proline. 
Fig. 17. Scatter plot of the PCA score

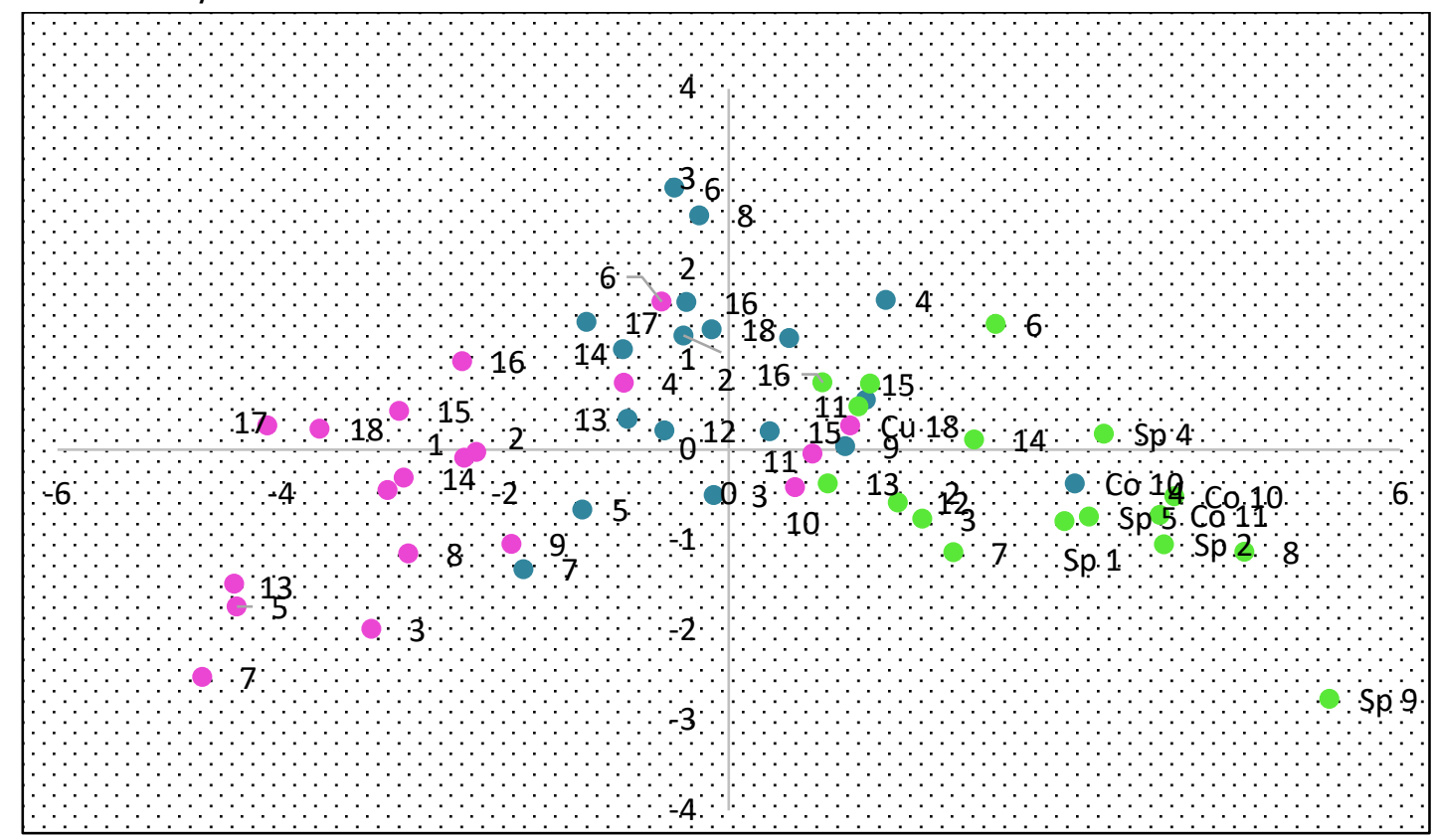

a

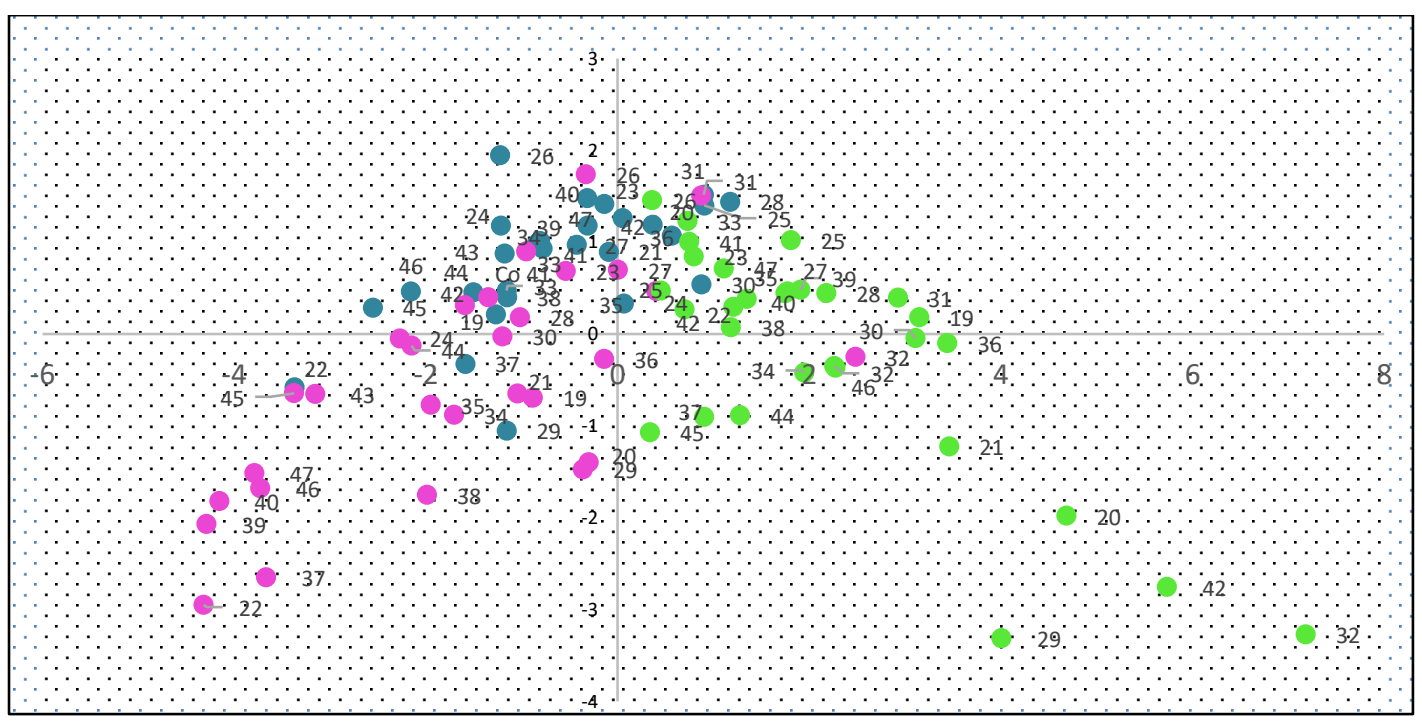

b

Note: Plants treated for two (a) or three weeks (b); control (green), water deficit (pink) and salt stress (blue) treatments. (a) 1-9, cultivars from Spain; 10-15, from Colombia and 16-18, from Cuba and (b) 19-32, cultivars from Spain; 33-45, from Colombia and 46 and 47 from Cuba

Based on the PCA scatter plot in the two-week trial (Fig. 17 a), we identified four accessions $(7,5,13$, and 17) with highly negative values for the first component (i.e., with high concentrations of Pro and low values for growth and water content parameters), both for the water deficit and salinity treatments; these cultivars can be 
considered as highly susceptible to both stresses. On the other hand, three accessions (25, 31 and 32) were detected in the three-week scatter plot (Fig. 17 b), showing positive values for the first component (low Pro contents and limited growth inhibition), both for the drought and salt stress treatments, indicating that these accessions can be considered as the most tolerant to both stresses. Similarly, the relative position of other accessions along the $x$-axis should allow a ranking of their tolerance to water deficit and to salinity, within each group of cultivars (treated for two or three weeks).

\subsubsection{Discussion}

In the present study, responses to drought and salinity have been analysed in 47 Phaseolus vulgaris genotypes of different origins. Large variability was observed in the size and morphology of the plants of the different bean cultivars-as seen when comparing their growth parameters (Supplementary Table S1) individually and also by their dispersion in the PCA scatterplots (Fig. 17)-making it difficult to determine, at first sight, the variables that are more relevant for assessing the relative degree of stress-induced growth inhibition and, therefore, for ranking the different cultivars according to their relative sensitivity or resistance to water deficit and salt stress. However, the statistical analyses performed with all experimental data provided a clear overall picture of the responses to stress of the P. vulgaris cultivars. Both 'cultivar' and 'treatment', as well as their interaction, had a highly-significant effect on (practically) all growth traits analysed, and on Pro contents, for the twoand threeweek treatments of both water deficit and salt stress. In all cases, growth inhibition was mostly reflected in the stress-induced reduction of fresh weight and water contents of stems (SFW and SWC) and leaves (LFW and LWC), as reported in the same species (Al Hassan et al., 2016; Morosan et al., 2017) or other species of this genus (Arteaga et al., 2018). These parameters are the growth variables most significantly correlated, positively, with the first principal component in the PCA. Pro, on the other 
hand, was the only variable showing a negative correlation with all growth variables, but particularly with those of stems and leaves mentioned above-as indicated by the Pearson correlation coefficients and the loading plots of the PCAs.

When comparing the stress tolerance of related taxa, for example, different cultivars of a particular crop, measurements of growth parameters are often complemented with the determination of several biochemical stress markers, associated with increased (or lower) tolerance; they include compatible solutes or osmolytes (Andrade et al., 2016; Bacha et al., 2017; Sen et al., 2017; Kozminska et al., 2019). Proline (Pro) is a common osmolyte in plants, which accumulates in response to different types of abiotic stress, including drought and salinity, in a variety of plant species (Szabados and Savouré, 2010; Verbruggen et al., 2008; Grigore et al., 2011 ; Parvaiz and Satyawati, 2008). Besides its role in cellular osmotic adjustment, Pro has additional functions as 'osmoprotectant'; it directly stabilises sub-cellular structures, such as membranes and proteins, scavenges free radicals buffering redox potential, alleviates cellular acidosis and acts as a signalling molecule in the responses to stress (Hayat et al., 2012; Rana et al., 2017). Proline also plays essential roles in the absence of stress, being involved in many developmental processes; for example, Pro concentration increases during pollen and seed maturation. However, Pro can be toxic for certain tissues if it is partially catabolised to pyrroline-5-carboxylate (P5C), leading to apoptosis (Kavi Kishor and Sreenivasulu, 2014). Considering the multiple functions of Pro, it is logical to assume that Pro accumulation would be associated with higher stress tolerance, and this has indeed been demonstrated for many plants, both wild species (Al Hassan et al., 2016; Al Hassan et al., 2016) and crop0073 (Arteaga et al., 201 8; Plazas et al., 2019). However, other comparative studies on related taxa, such as species of the same genus or cultivars or varieties of the same species, revealed higher Pro accumulation under stress in the less-tolerant genotypes (Chen et al., 2007; Kozminska et al., 2018). 
There is some confusion, often found in the literature, between the concepts of 'stress responses' and 'stress tolerance'. Even though stress tolerance mechanisms are based on specific stress responses, not all responses are relevant for tolerance. On this line, Pro accumulation can be considered as a general 'response' to abiotic stress in many plant species, but Pro may or may not be involved in stress tolerance mechanisms, depending on the species.

Common bean is clearly a Pro accumulator species, as numerous reports have shown significant increases in Pro contents in Phaseolus plants in response to either salt stress (Jimenez-Bremont et al., 2006; Al Hassan et al., 2016; Nagesh and Devaraj, 2008) or water stress (Morosan et al., 2017; Ashraf and Iram, et al., 2005; Rosales et al., 2012) treatments. Also, Pro appears to be a good bioindicator in other types of stress in beans, such as that induced by excess nitrogen dosage (Sánchez et al., 2001), herbicides (Mackay et al., 1990) or heavy metals (Zengin and Munzuroglu, 2005).

Moreover, exogenous application of Pro was shown to alleviate the salt stress deleterious effects in beans (Abdelhamid et al., 2013). However, there are some contradictory data in the literature regarding the function of Pro in the mechanisms of stress tolerance in Phaseolus. Some published reports indicated higher Pro contents in more drought-tolerant (Kapuya et al., 1985; Herrera Flores et al., 2012; Ghanbari et al., Kusvuran et al., 2017; Wang et al., 2019) or salt-tolerant (Misra and Gupta, 2005; Cárdenas-Avila et al., 2006; Kaymakonova and Stoeva et al., 2008) cultivars than in less tolerant ones; that is, Pro accumulation correlates positively with the degree of stress resistance, suggesting a direct contribution to stress tolerance mechanisms. Other reports, on the contrary, showed that, under stress conditions, the less tolerant genotypes had a higher concentration of this osmolyte than the more resistant cultivars (Jimenez-Bremont et al., 2006; Al Hassan et al., 2016; Morosan et al., 2017; Domínguez et al., 2014); therefore, in this case, Pro is simply a marker of 
the level of stress affecting the plants, accumulating at higher concentrations in the more stressed-the more sensitive-cultivars, but is not directly involved in the mechanisms of tolerance. This was also the conclusion of previous work from our laboratory, comparing three commercial cultivars (two of $P$. vulgaris and one of $P$. coccineus) and one Spanish common bean landrace (Al Hassan et al., 2016; Morosan et al., 2017). All these latter studies, based on the comparison of a few bean genotypes, generally some commercial cultivars, have been confirmed in the present work, using a much larger number of cultivars of different origins and an extensive statistical analysis of the experimental data.

Our results showed a strong negative correlation of Pro levels and growth variables, especially the fresh weight and water content of the aboveground organs of the plants; these are the most relevant parameters to evaluate the inhibition of growth induced under water deficit and high salinity conditions. Therefore, there is an unequivocal association of higher Pro contents with stronger growth inhibition; that is, with a higher sensitivity to stress of the bean cultivars.

\subsubsection{Conclusions}

Phaseolus vulgaris cannot be considered as drought- or salt-tolerant. It is even more sensitive to stress than many other crops such as barley or cowpea (Gürel et al., 2016; Yoshida et al., 2020). However, amongst the extremely high number of available genotypes of $\mathrm{P}$. vulgaris, some will show a relatively higher resistance and could be used as parental lines in bean breeding programmes aimed at enhancing stress tolerance in this major crop. The identification of common bean accessions in the extremes of variation for susceptibility and tolerance to water deficit and salinity is of great interest for further studies on the physiological mechanisms of tolerance to both stresses. Also, the development of segregating generations after hybridisation between both types of materials can lead to the identification of genomic regions involved in tolerance to these stresses. Proline concentrations in 
stressed plants can be determined by a simple and rapid spectrophotometric assay, requiring only small amounts of leaf material. From a practical point of view, our results support the use of Pro as a biochemical marker for the initial, large-scale screening of bean cultivars, to exclude the most sensitive, those accumulating higher Pro concentrations in response to water or salt stress.

Supplementary Materials: The following are available online at http://www.mdpi.com/2073-4395/10/6/817/s1, Table S1: Variation of morphological parameters and proline concentrations in 47 accessions of common bean (Phaseolus vulgaris) under salt stress and water stress.

Author Contributions: Conceptualization, M.B. and O.V.; methodology, S.A. and L.Y.; software, J.P.; validation, M.J.D. and J.P.; formal analysis, L.Y.; investigation, S.A. and L.Y.; resources, O.V.; data curation, S.A.; writing-original draft preparation, S.A. and M.B.; writing-review and editing, M.J.D., J.P. and O.V.; visualization, S.A.; supervision, M.B. and O.V.; project administration, M.B. and O.V.; funding acquisition, O.V. All authors have read and agreed to the published version of the manuscript.

Funding: This research received no external funding.

Acknowledgments: We are indebted to Steve Beebe, from Alliance Biodiversity CIAT, for providing the Colombian bean cultivars and for his helpful comments on the manuscript. Conflicts of Interest: The authors declare no conflict of interest. 


\section{References}

Abdelhamid, M.T., Rady, M.M., Osman, A.S., Abdalla, M.A. (2013). Exogenous application of proline alleviates salt-induced oxidative stress in Phaseolus vulgaris L. plants. J. Hortic. Sci. Biotech, 88, 439-446.

Al Hassan M., Morosan M., López-Gresa M.P., Prohens J., Vicente O., Boscaiu M. (2016). Salinity-induced variation in biochemical markers provides insight into the mechanisms of salt tolerance in common (Phaseolus vulgaris) and runner (P. coccineus) beans. Int. J. Mol. Sci., 17, 1582.

Al Hassan M., Pacurar A., López-Gresa M.P., Donat-Torres M., Llinares, J., Boscaiu M., Vicente O. (2016). Effects of salt stress on three ecologically distinct Plantago species. PLOS ONE, 11, e0160236.

Al Hassan M., López-Gresa M.P., Boscaiu M., Vicente O. (2016) Stress tolerance mechanisms in Juncus: Responses to salinity and drought in three Juncus species adapted to different natural environments. Funct. Plant Biol., 43, 949960.

Andrade E., Ribeiro V., Azvedo C., Chiorato A., Williams T., Carbonell S. (2016) Biochemical indicators of drought tolerance in the common bean (Phaseolus vulgaris L.). Euphytica, 210, 277-289.

Arteaga S., Yabor L., Torres J., Solbes E., Muñoz E., Díez M.J., Vicente O., Boscaiu M. (2019). Morphological and agronomic characterization of Spanish landraces of Phaseolus vulgaris L. Agriculture, 9, 149.

Arteaga S., Al Hassan M. Wijesinghe C., Yabor L., Llinares J., Boscaiu M., Vicente O. (2018). Screening for Salt Tolerance in Four Local Varieties of Phaseolus Iunatus from Spain. Agriculture, 8, 201.

Ashraf M., Iram A. (2005). Drought stress induced changes in some organic substances in nodules and other plant parts of two potential legumes differing in salt tolerance. Flora, 200, 535-546.

Bacha H., Tekaya M., Drine S., Guasami F., Touil L., Enneb H., Triki T., Cheour F., Ferchichi A. (2017). Impact of salt stress on morpho-physiological and biochemical parameters of Solanum lycopersicum cv. Microtom leaves. S. Afr. J. Bot., 108, 364-369.

Bates L.S., Waldren R.P., Teare I.D. (1973). Rapid determination of free proline for water stress studies. Plant Soil, 39, 205-207. 
Belluci E., Bitocchi E., Rau D., Rodriguez M., Biagetti E., Giardini A., Attene G., Nanni L., Papa R. (2013). Genomics of Origin, Domestication and Evolution of Phaseolus vulgaris. Genomics of Plant Genetic Resources pp 483-507.

Broughton W.J., Hernandez G., Blair M. et al (2003) Beans (Phaseolus spp.)-model food legumes. Plant Soil 252:55-128.

Brucher O.B., Brucher H. (1976). The South American wild bean (Phaseolus aborigeneus Burk.) as ancestor of the common bean. Econ. Bot., 30, 257-272.

Cárdenas-Avila M., Verde-Star J., Maiti R., Foroughbakhch R., Gámez-González H., Martínez-Lozano, S., Núñez-González M., García Díaz G., Hernández-Piñero J., Morales-Vallarta M. (2006). Variability in accumulation of free proline on in vitro calli of four bean (Phaseolus vulgaris L.) cultivars exposed to salinity and induced moisture stress. Phyton, 75, 103-108.

Chen Z., Cuin T., Zhou M., Twomei A., Naidu B., Shabala S. (2007). Compatible solute accumulation and stress-mitigating effects in barley genotypes contrasting in their salt tolerance. J. Exp. Bot., 58, 4245-4255.

Cuellar-Ortiz S., Arrieta-Montiel M., Acosta-Gallegos J., Covar-Rubias A. (2008). Relationship between carbohydrate partitioning and drought resistance in common bean. Plant Cell Environ., 31, 1399-1409.

Debouck D.G., Smartt J. (1995). Bean. In Evolution of Crop Plants, 2nd ed.; Smartt, J., Simmonds, N.W., Eds.; Longman Scientific and Technical: Harlow, UK, pp. 287-296.

Delgado-Salinas A., Bibler R., Lavin M. (2006) Phylogeny of the genus Phaseolus (Leguminosae): A recent diversification in an ancient landscape. Syst. Bot., 31 , 779-791.

Domínguez A., Yunel-Pérez Y., Alemán S., Sosa M., Fuentes L., Darias R., Demey J., Rea R., Sosa D. (2014). Respuesta de cultivares de Phaseolus vulgaris L. al estrés por sequía. Biot. Veg. 14, 29-36.

Fess T.L., Kotcon J.B., Benedito V.A. (2011). Crop breeding for low input agriculture: A sustainable response to feed a growing world population. Sustainability, 3, $1742-1772$.

Fita A., Rodríguez-Burruezo A., Boscaiu M., Prohens J., Vicente O. (2015). Breeding and domesticating crops adapted to drought and salinity: A new paradigm for increasing food production. Front. Plant Sci., 6, 978. 
Flowers T., Flowers S. (2005). Why does salinity pose such a difficult problem for plant breeders? Agric. Water Manag., 78, 15-24.

Freytag G.F., Debouck D.G. (2002). Taxonomy, Distribution, and Ecology of the genus Phaseolus (Leguminosae-Papilionoideae) in North America, Mexico and Central America; Botanical Research Institute of Texas (BRIT): Forth Worth, TX, USA, pp. 1-298.

Gama P.B.S., Inanaga S., Tanaka K., Nakazawa R. (2007), Physiological response of common bean. (Phaseolus vulgaris L.) seedlings to salinity stress. Afr. J. Biotechnol., 6, 79-88.

Gepts P., Debouck D.G. (1991). Origen. Domestication and evolution of the common bean (Phaseolus vulgaris L.). In: Schoonhoven, A. Van and Voyset, O. (Eds.). Common bean research for crop improvement. CAB. International. 7-53 p.

Ghanbari A.A., Mousavi S.H., Mousapou-Gorji A., Rao I. (2013). Effects of water stress on leaves and seeds of bean (Phaseolus vulgaris L.). Turk. J. Field Crops, $18,73-77$.

Graham P., Ranalli P. (1997). Common bean (Phaseolus vulgaris L.). Field Crop Res. $1997,53,131-146$.

Grigore, M.N.; Boscaiu, M.; Vicente, O. Assessment of the relevance of osmolyte biosynthesis for salt tolerance of halophytes under natural conditions. Eur. J. Plant Sci. Biotechnol. 2011 , 5, 12-19.

Gürel, F.; Öztürk, Z.N.; Uçarlı, C.; Rosellini, D. Barley genes as tools to confer abiotic stress tolerance in crops. Front Plant Sci. 2016, 7, 1137.

Hayat S., Hayat Q., Alyemeni M.N., Wani A.S., Pichtel J., Ahmad, A. (2012). Role of proline under changing environments: A review. Plant Signal. Behav., 7, 14561466.

Herrera-Flores T.S., Ortíz-Cereceres J., Delgado-Alvarado A., Acosta-Galleros J.A. (2012). Growth and, proline and carbohydrate content of bean seedlings subjected to drought stress. Rev. Mexicana Cienc. Agric., 3, 713-725.

Hoagland D., Arnon D. (1950). The water-culture method for growing plants without soil. Circ. Califor. Agric. Exp. Stat., 347, 32-63.

Hurtado M., Vilanova S., Plazas M., Gramazio P., Andújar I., Herraiz F.J., Prohens J. (2014). Enhancing conservation and use of local vegetable landraces: The 
Almagro eggplant (Solanum melongena L.) case study. Genet. Resour. Crop Evol., 61, 787-795.

Jiménez-Bremont J.F., Becerra-Flora A., Hernández-Lucero E., Rodríguez-Kessler M., Acosta-Gallegos J.A., Ramírez-Pimentel J.G. (2006). Proline accumulation in two bean cultivars under salt stress and the effect of polyamines and ornithine. Biol. Plant. 50, 763-766.

Kapuya J.A., Barendse G.W.M., Linskens H.F. (1985). Water stress tolerance and proline accumulation in Phaseolus vulgaris L. Acta Bot. Neerl., 34, 293-300.

Kavi Kishor, P.; Sreenivasulu, N. Is proline accumulation per se correlated with stress tolerance or is proline homeostasis a more critical issue? Plant Cell Environ. 2014, 37, 300-311.

Kaymakonova M., Stoeva N. (2008). Physiological responses of bean plants (Phaseolus vulg. L.) to salt stress. Gen. Appl. Plant Physiol., 34, 177-188.

Kozminska A., Wiszniewska A., Hanus-Fajerska E., Boscaiu M., Al Hassan M., Halecki W., Vicente O. (2019). Identification of salt and drought biochemical stress markers in several Silene vulgaris populations. Sustainability, 11, 800.

Kozminska A., Al Hassan M., Hanus-Fajerska E., Naranjo M.A., Vicente O., Boscaiu M.(2018). Comparative analysis of water deficit and salt tolerance mechanisms in Silene. S. Afr. J. Bot., 117, 193-206.

Kusvuran S., Dasgan H.Y. (2017). Effects of drought stress on physiological and biochemical changes in Phaseolus vulgaris L. Legume Res., 40, 55-62.

Maas E., Hoffman G. (1977). Crop salt tolerance-current assessment. J. Irrig. Drain. Eng., 103, 115-134.

Mackay C.E., Hall C., Hofstra G., Fletcher R.A. (1990). Uniconazole-induced changes in abscisic acid, total amino acids, and proline in Phaseolus vulgaris. Pesticide Biochemistry and Physiology 37:74-82.

Mantri N., Patade V., Penna S., Ford R., Pang E. (2012). Abiotic stress responses in plants: Present and future. In Abiotic Stress Responses in Plants: Metabolism, Productivity and Sustainability; Ahmad, P., Prasad, M.N.V., Eds.; Springer. New York, NY, USA, pp. 1-19.

Misra N., Gupta A.K. (2005). Effect of salt stress on proline metabolism in two high yielding genotypes of green gram. Plant Sci., 169, 331-339. 
Molina J., Moda-Cirino V., Da Silva Fonseca N.J., Faria R., Destro D. (2001). Response of common bean cultivars and lines to water stress. Crop Breed. Appl. Biotechnol. $2001,1$.

Morosan M., Al Hassan M., Naranjo M., Lopez-Gresa M.P., Vicente O. (2017). Comparative analysis of drought responses in Phaseolus vulgaris (common bean) and $P$. coccineus (runner bean) cultivar. EuroBiotech J., 1, 247-252.

Morton J.F. (2007). The impact of climate change on smallholder and subsistence agriculture. Proc. Natl. Acad. Sci. USA, 104, 19680-19685.

Nagesh B., Devaraj V. (2008). High temperature and salt stress response in French bean (Phaseolus vulgaris). Austr. J. Crop Sci., 2, 40-42.

Ortwin-Sauer C. (1966). The Early Spanish Men; University of California Press: Berkeley, CA, USA.

Osakabe Y., Osakabe K.,Shinozaki K., Tran L. (2014). Response of plants to water stress. Front. Plant Sci., 5, 86.

Parvaiz A.S., Satyawati S. (2008). Salt stress and phyto-biochemical responses of plants-A review. Plant Soil Environ., 54, 89-99.

Plazas M., Nguyen H., González-Orenga S., Fita A., Vicente O., Prohens J., Boscaiu M. Comparative analysis of the responses to water stress in eggplant (Solanum melongena) cultivars. Plant Physiol. Biochem. 201 9, 143, 72-82.

Pinheiro C., Baeta J.P., Pereira A.M., Dominguez H., Ricardo C. (2007). Mineral elements correlations in a Portuguese germplasm collection of Phaseolus vulgaris. Integrating Legume Biology for sustainable Agriculture. In Proceedings of the 6th European Conference on Grain Legumes, Lisbon, Portugal, pp. 125-126.

Rana V., Ram S., Nehra K. (2017). Proline biosynthesis and its role in abiotic stress. Int. J. Agric. Res. Innov. Technol. 6.

Rendón-Anaya M., Montero-Vargas J.M., Saburido-Álvarez S., Vlasova A., CapellaGutierrez S., Ordaz-Ortiz J.J., Aguilar O.M., Vianello-Brondani R.P., Santalla M., Delaye L. et al. (2017). Genomic history of the origin and domestication of common bean unveils its closest sister species. Genome Biol., 18, 60.

Rosales M.A., Ocampo O., Rodríguez-Valentín R., Olvera-Carrillo Y., Acosta-Gallegos J., Covarrubias A.A. (2012). Physiological analysis of common bean (Phaseolus 
vulgaris L.) cultivars uncovers characteristics related to terminal drought resistance. Plant Physiol. Biochem., 56, 24-34.

Sánchez E., Ruiz J.M., López-Lefebre L.R., Rivero R.M., García P.C., Romero L. (2001) Proline metabolism in response to highest nitrogen dosages in green bean plants (Phaseolus vulgaris L. cv Strike). J. Plant Physiol., 158, 593-598.

Sen A., Ozturk I., Yaycili O., Alikamanoglu S. (2017). Drought tolerance in irradiated wheat studied by genetic and biochemical markers, 36, 669-676.

Singh S.P. (2007). Drought resistance in the race Durango dry bean landraces and cultivars. Agron. J., 99, 1219-1225. [CrossRef. J. Plant Growth Regul.]

Shahid S.A., Zaman M., Heng L. (2018). Soil salinity: Historical perspectives and a world overview of the problem. In Guideline for Salinity Assessment, Mitigation and Adaptation Using Nuclear and Related Techniques; Zaman, M., Shahid, S.A., Eds.; Springer. Cham, Switzerland; pp. 43-53.

Szabados L., Savouré A. (2010). Proline: A multifunctional amino acid. Trends Plant Sci., 15, 89-97.

Verbruggen N., Hermans C. (2008). Proline accumulation in plants: A review. Amino Acids, 35, 753-759.

Verslues P.E., Sharma S. (2010). Proline metabolism and its implications for plantenvironment interaction. Arabidopsis Book, 8, e0140.

Wang Q, Ang Q., Lin F., Wei S.H., Meng X.X., Yin Z.G., Guo Y.F. Yang G.D. (2019). Effects of drought stress on endogenous hormones and osmotic regulatory substances of common bean (Phaseolus vulgaris L.) at seedling stage. Appl. Ecol. Environ. Res., 17, 4447-4457.

Yoshida J., Tomooka N., Khaing T.Y., Sunil-Shantha P.G., Naito H., Matsuda Y., Ehara H. (2020). Unique responses of three highly salt-tolerant wild Vigna species against salt stress. Plant Prod. Sci, 23, 114-128.

Zengin F.K., Munzuroglu O. (2005). Effects of some heavy metals on content of chlorophyll, proline and some antioxidant chemicals in bean (Phaseolus vulgaris L.) seedlings. Acta Biol. Cracov. Bot., 47, 157-164.

Zörb C., Geilfus C.M., Dietz K. (2018). Salinity and crop yield. Plant Biol., 21: 31-38.

Zhumabayeva B.A., Biotechnology K.A., Aytasheva Z.G., Dzhangalina E.D., Esen A.. Lebedeva L.P. (2019), Screening of domestic common bean cultivar for salt tolerance during in vitro cell cultivation. Int. J. Biol., 12, 94-102. 
Subcapitulo 3.4. Role of active transport of potassium to leaves in the mechanisms of tolerance to salinity in common bean (Phaseolus vulgaris L.)

Reference:

Sugenith Arteaga, Monica Boscaiu, Jaime Prohens, Oscar Vicente. 2020. Notulae Scientia Biologicae 12(2):447-459. DOI: 10.15835/nsb12210751 


\title{
Role of active transport of potassium to leaves in the mechanisms of tolerance to salinity in common bean (Phaseolus vulgaris L.)
}

\begin{abstract}
Biochemical markers are of great utility in screening for salt tolerance of crops. In common beans (Phaseolus vulgaris), lower levels of proline under stress have been associated with a better stress resistance of cultivars. In the present study, the responses to salinity have been analysed in six cultivars of common beans: four local landraces from Spain and two experimental lines from Cuba. Proline was used for ranking the relative tolerance of the cultivars, confirming a previous study which reported as more stress-tolerant two of the Spanish landraces. Total soluble sugars concentrations varied with treatments and between genotypes, but it was difficult to assess their role in stress tolerance of the analysed plants. Sodium concentration in leaves was the lowest in one of the two salt-resistant cultivars, and potassium did not vary or even increased under salt stress in all of them, except for the most susceptible one, where a drop of this cation was registered under $150 \mathrm{mM} \mathrm{NaCl}$. Changes in malondialdehyde (MDA) contents did not indicate salt-induced membrane peroxidation resulting from secondary oxidative stress; consequently, accumulation of total phenolic compounds and flavonoids, as an antioxidant defence mechanism, was not detected. These results highlight the reliability of using proline as a biochemical marker of salt stress in common beans and the importance of the mechanism related to potassium transport to leaves in conferring stress tolerance to some common bean cultivars.
\end{abstract}

Keywords: bean cultivars; potassium transport; proline; salt stress; sodium exclusion. 


\subsubsection{Introduction}

The formidable challenge for agriculture represented by global warming and other harmful effects of climate change makes studies on stress tolerance in crops particularly relevant. An ever-growing human population, which will reach almost 10 x 109 people by the middle of the century, will need around $70 \%$ more food and plant products provided by agriculture (Dwivedi et al., 2016). Agriculture, in areas with an arid and semi-arid climate, and soon also in other parts of the world that will be affected by climate change, relies on the extensive use of irrigation, which triggers in time the so-called secondary salinisation. This is produced by the accumulation of toxic ions in the soil from the irrigation water and is causing an enormous loss of arable land every year (Daliakopoulos et al., 2016). Highly productive elite germplasm developed to provide high yields under optimal cultivation conditions (irrigation, high agrochemical inputs) may not cope with environmental restrictions imposed by climate change (Fita et al., 2015). Climate-smart agriculture can rely on improving cultural technologies, such as adjusting planting and harvesting time, genetic engineering approaches or the use of cultivars or new crops better adapted to environments prone to abiotic stress (Raza et al., 2019). Landraces developed as a result of the human-mediated and natural selection of traits adapted to local conditions, often suboptimal or even highly stressful. They shelter a high phenotypic variability, and some are tolerant to abiotic or biotic stresses (Mercer and Perales, 2010). Therefore, landraces represent a valuable source of allelic richness that may have an important role in the breeding of new varieties and also have an additional market value as they are increasingly demanded by consumers as healthier and tastier (Hurtado et al., 2014). Screening for stress tolerance in local landraces is achieving more and more relevance (Arteaga et al., 2019, 2020). However, the mere knowledge of which varieties are more tolerant to stress is not sufficient; the key is to analyse the mechanisms supporting this tolerance. Plants respond to stress factors by the 
activation of a series of conserved responses at the cellular, tissue, organ and whole plant levels (Larcher, 2003). Plant growth, especially the reduction of their fresh weight and water content, are optimal parameters indicating the level of stress affecting the plants since these processes depend on the metabolic and physiological capacity for adaptation and acclimatisation to environmental conditions. Under salt stress, the levels of ions, especially potassium and sodium, both in roots and leaves, are also good indicators of stress tolerance in plants. Compatible solutes, also called osmolytes, are diverse chemical compounds, which contribute to the osmotic adjustment and play osmoprotective roles, acting as low-molecular-weight chaperons in the stabilisation of proteins, membranes and other macromolecular structures under conditions of cell dehydration, as well as in reactive oxygen species (ROS) detoxification (Hussain et al., 2008; Szabados and Savouré, 2010). Excessive ROS accumulation that occurs under different types of stresses in plants causes oxidative stress, which activates antioxidant systems, both enzymatic and nonenzymatic, for prevention or reducing oxidative damage to proteins, membranes and DNA (Apel and Hirt, 2004; Türkan and Demiral, 2009). Amongst the major nonenzymatic antioxidants are phenolic compounds, especially flavonoids, which have a markedly antioxidant activity since they undergo oxidation before other compounds and therefore protect against oxidant attacks.

Common bean (Phaseolus vulgaris L.) is an essential legume in human nutrition (Broughton et al., 2003), with Mesoamerican and Andean origin (Gepts and Debouck, 1991; Rendón-Anaya et al., 2017), but cultivated since centuries in Europe, where a secondary centre of diversification emerged in the Iberian Peninsula (Pinheiro et al., 2007). Common bean is a glycophyte, sensitive to salt stress, as the vast majority of crops. However, not all cultivars respond equally to salt stress, some showing a better adjustment than others to saline soils (Gama et al., 2007; Kaymakanova and Stoeva, 2008; Al Hassan et al., 2016). 
This study aims to analyse the mechanisms of response to salt stress in a selection of cultivars (both tolerant and susceptible to salinity) regarding (i) accumulation of osmolytes, (ii) ionic homeostasis, (iii) levels of malondialdehyde (MDA) as an indicator of oxidative stress, and (iv) accumulation of total phenolic compounds and flavonoids as representative non-enzymatic antioxidants.

\subsubsection{Materials and Methods}

\section{Plant material}

The study included four local landraces of Phaseolus vulgaris from Spain (BGV001 191, BGV001581, BGV004161 and BGV015856) and two experimental lines from Cuba (E-125 and Milagro VIII) from INIFAT (Alexander Humboldt Institute for Basic Research in Tropical Agriculture) and IIHDL (Liliana Dimitrova Horticultural Research Institute, La Habana, Cuba). The seeds were provided by the Germplasm bank of the Institute for the Conservation and Improvement of Valencian Agrobiodiversity (COMAV) of the Polytechnic University of Valencia, Spain, and the Bioplants Center, University of Ciego de Ávila, Cuba, respectively. A previous study (Arteaga et al., 2020) reported that cultivars BGV004161 BGV015856 were relatively more salt and drought tolerant, whereas the others, in particular, E125 were more susceptible to these two types of stress.

Table 15. Origin of the common bean cultivars analysed.

\begin{tabular}{lccc}
\hline Genebank's code & Country & Origin & Name of the cultivar \\
\hline BGV001191a & Spain & Almería & Judía \\
BGV001581a & Spain & Palma de Mallorca & Judia de careta \\
BGV004161a & Spain & Plasencia, Cáceres & \\
BGV015856a & Spain & Alicante & Habichuela del barco \\
E125b & Cuba & IIHLD & \\
Milagro VIIIb & Cuba & INIFAT & Milagro Villareñoa \\
\hline a Local landraces; b experimental lines
\end{tabular}




\section{Plant growth and stress treatments}

Seeds were germinated in trays with peat, perlite and vermiculite $(2: 1: 1)$. Once the first true leaves were formed, seedlings were transplanted to individual $1.6 \mathrm{~L}$ pots with the same substrate and irrigated with Hoagland's nutrient solution (Hoagland and Arnon, 1950). Salt treatments were started when the plants reached a height of ca. $20 \mathrm{~cm}$ by watering twice a week with aqueous solutions of 50,100 and $150 \mathrm{mM}$ $\mathrm{NaCl}$, or with deionised water for the control treatments (Fig. 18). Treatments were extended for 18 days in the greenhouse under the following conditions: long-day photoperiod ( $16 \mathrm{~h}$ of light and $8 \mathrm{~h}$ of darkness), temperature of $23 \circ \mathrm{C}$ during the day and $17 \circ \mathrm{C}$ at night, and relative humidity ranging between $50 \%$ and $80 \%$.

Fig. 18. Plants exposed to saline stress treatments
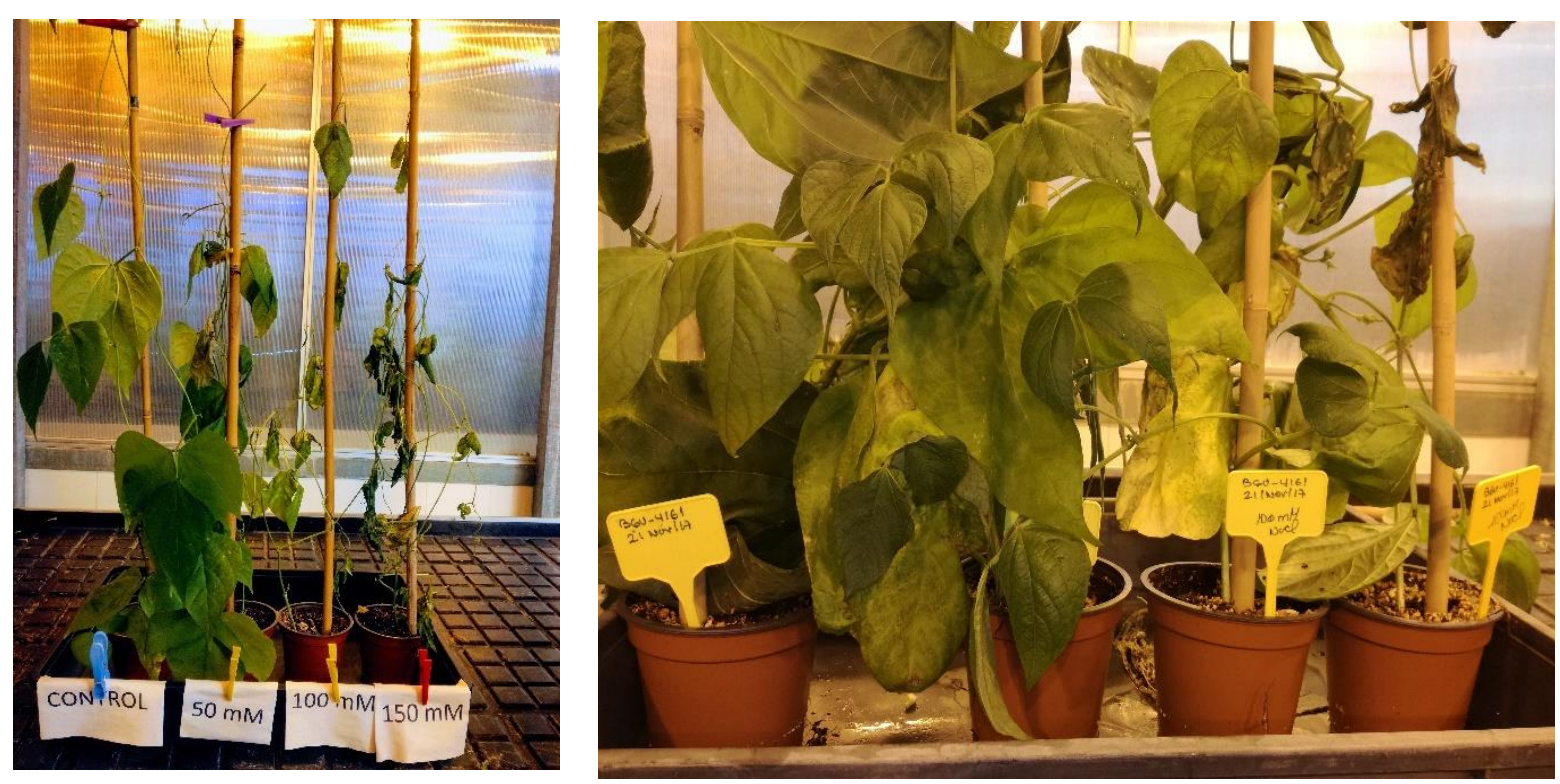

\section{Osmolyte quantification}

Proline (Pro) determination was performed following the classical method described by Bates et al. (1973) with small laboratory modifications. Fresh leaf material was extracted in a $3 \%(\mathrm{w} / \mathrm{v})$ sulfosalicylic acid solution, then mixed with acid ninhydrin, incubated for one hour at $95^{\circ} \mathrm{C}$, cooled on ice and extracted with two volumes of toluene. After collecting the upper organic phase, its absorbance was read 
at $520 \mathrm{~nm}$, with toluene used as a blank. Total soluble sugars (TSS) were extracted from dry leaf material with $80 \%(\mathrm{v} / \mathrm{v})$ methanol, mixed on a rocker shaker for $24 \mathrm{~h}$ and then quantified spectrophotometrically at $490 \mathrm{~nm}$, following the phenol/sulphuric acid method (Dubois et al., 1956). The concentrations of TSS were expressed as "mg equivalent of glucose" per g DW.

\section{Monovalent ions measurements}

Samples were extracted by incubating $0.15 \mathrm{~g}$ of ground dry leaf material in $25 \mathrm{~mL}$ of water for one hour at $95^{\circ} \mathrm{C}$ in a water bath (Weimberg, 1987), followed by cooling the sample on ice and filtration through a $0.45 \mu \mathrm{m}$ filter (Gelman Laboratory, PALL Corporation). Sodium and potassium were measured in a PFP7 flame photometer (Jenway Inc., Burlington, VT, USA).

\section{MDA and non-enzymatic antioxidants quantification}

Malondialdehyde (MDA), total flavonoids (TF) and total phenolic compounds (TPC) were determined in $80 \%(\mathrm{v} / \mathrm{v})$ methanol extracts of $100 \mathrm{mg}$ of fresh plant material. MDA was determined following the protocol of Hodges et al. (1999). Extracts were mixed with $0.5 \%$ thiobarbituric acid (TBA), prepared in $20 \%$ TCA (or with $20 \%$ TCA without TBA for the controls), and were then incubated at $95^{\circ} \mathrm{C}$ for $20 \mathrm{~min}$. After stopping the reaction on ice, the supernatant's absorbance was measured at $532 \mathrm{~nm}$. The non-specific absorbance at 600 and $440 \mathrm{~nm}$ was subtracted, and the MDA concentration was calculated with the equations described in Hodges et al. (1999).

Total phenolic compounds (TPC) were quantified as described in Blainski et al. (2013) by reaction with the Folin-Ciocalteu reagent. The extracts were mixed with the reagent and sodium carbonate and left in the dark for $90 \mathrm{~min}$. Absorbance was recorded at $765 \mathrm{~nm}$, and the results were expressed in equivalents of gallic acid, used as a standard (mg eq GA g-1 DW).

Total flavonoids (TF) were measured by reaction of the methanol extracts with NaNO2 followed by $\mathrm{AlCl} 3$ at a basic pH (Zhishen et al., 1999). Absorbance was 
measured at $510 \mathrm{~nm}$, and the TF contents were expressed in 'equivalents of catechin, used as a standard (mg eq $\left.\mathrm{C} \mathrm{g}^{-1} \mathrm{DW}\right)$.

\section{Statistical analysis}

Data were analysed using the software Statgraphics Centurion v.16 (Statpoint Technologies, Warrenton, VA, USA). A two-way analysis of variance (ANOVA) was performed for all traits analysed to check the interaction between the genotype and the treatments in all cultivars. The post-hoc Tukey test $(p<0.05)$ was used to check the effect of treatment in each genotype separately.

\subsubsection{Results}

\section{Osmolytes}

Two main types of osmolytes have been analysed in the six accessions of common bean. Proline (Pro) increased in response to salt stress in all cultivars, and differences with respect to other treatments were significant in the presence of 150 $\mathrm{mM} \mathrm{NaCl}$, for all cultivars. However, a considerable difference in Pro concentration was noticed between cultivars, with maximal values ranging from $56 \mu \mathrm{mol} \mathrm{g-1} \mathrm{DW} \mathrm{in}$ BGV004161 to $106 \mu \mathrm{mol} \mathrm{g}^{-1} \mathrm{DW}$ in BGV001191. Also, there was a clear difference in the relative increase of Pro contents, in relation with its background values in the non-stressed controls, which were more pronounced in BGV001191 and BGV001581, whereas the smallest increase was registered in BGV004161 and BGV015856 (Fig. 19;Error! No se encuentra el origen de la referencia. A).

Total soluble sugars (TSS) did not vary significantly in the cultivars BGV001191 and BGV001581. In BGV004161 and Milagro VIII, TSS showed an increase under 50 and $100 \mathrm{mM} \mathrm{NaCl}$, followed by a drop at $150 \mathrm{mM} \mathrm{NaCl}$. In cultivars BGV015856 and E125, TSS increased in parallel to the concentration of $\mathrm{NaCl}$ applied, but not all differences were significant (Fig. 19 B). 
Fig. 19. Variation of osmolytes contents in response to salt stress in the six cultivars of common beans analysed; (A) Proline; (B) Total soluble sugars

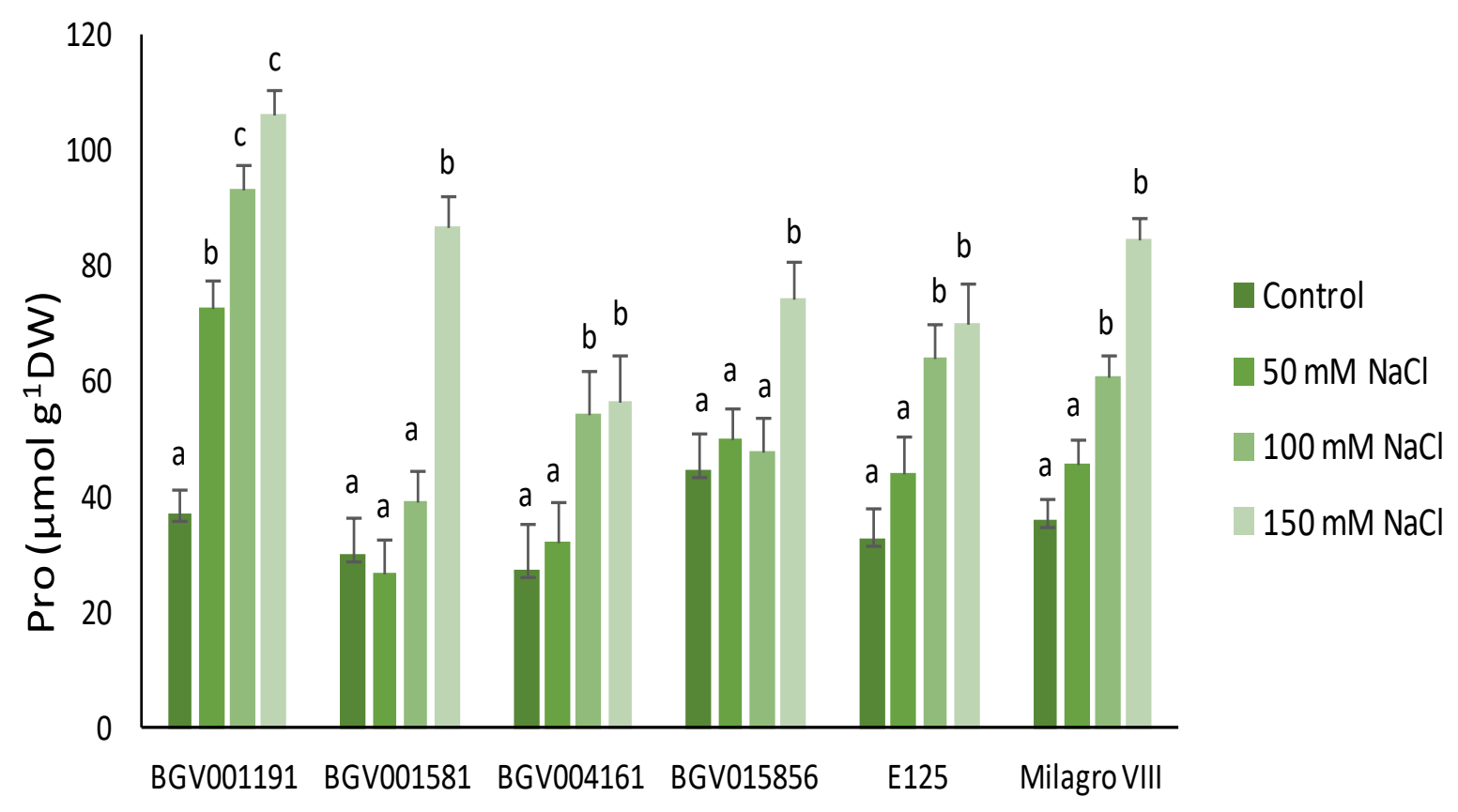

A

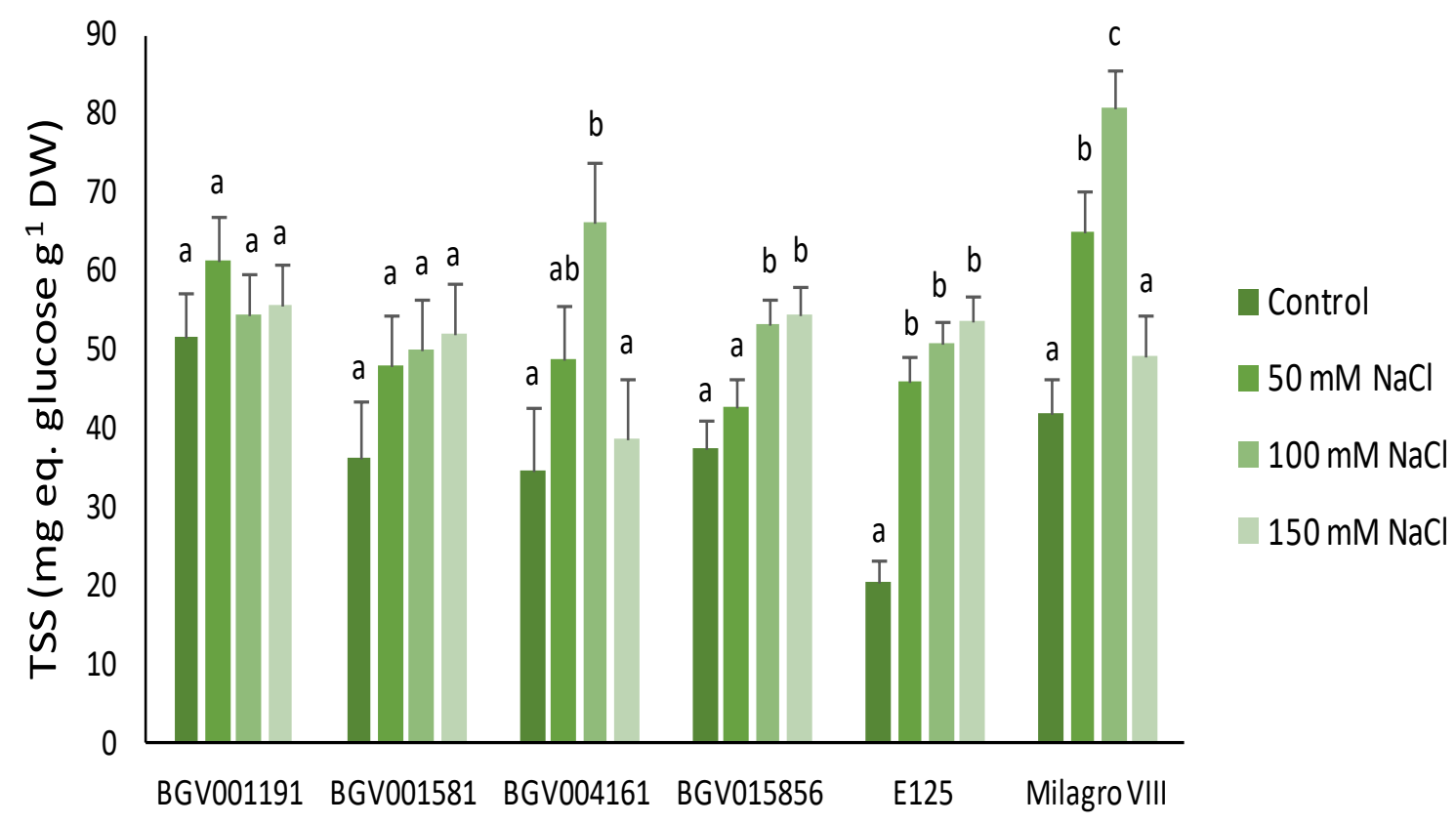

B

Note: Mean \pm SE values are shown $(n=5)$. Same lowercase letters within each column indicate homogeneous groups between treatments according to the Tukey test $(p<0.05)$ 


\section{Monovalent ions}

$\mathrm{Na}^{+}$increased in all plants subjected to salt stress in parallel to the concentration of $\mathrm{NaCl}$ applied. The lowest levels of foliar $\mathrm{Na}^{+}$under salt stress were found in the cultivar BGV015856 and the highest in BGV001191, but in the latter, the relative increase was small, as $\mathrm{Na}^{+}$concentration was also high in the control plants. The variation of $\mathrm{Na}^{+}$levels in plants treated with $150 \mathrm{mM} \mathrm{NaCl}$, in comparison to nonstressed plants, ranged from 2.3-fold in BGV015856 and 2.72-fold in BGV001191 to over 4 -fold in the remaining cultivars (Fig. $20 \mathrm{~A}$ ).

$\mathrm{K}^{+}$levels in leaves did not vary significantly at low or moderate external salinities and generally increased in the plants treated with the highest $\mathrm{NaCl}$ concentrations, except for cultivar E125, in which a reduction of leaf $\mathrm{K}+$ contents was observed in the presence of $150 \mathrm{mM} \mathrm{NaCl}$. The highest relative increase in $\mathrm{K}+(1.8-$ fold), was registered in cultivar BGV001191, characterised by lower values of this cation in control plants (Fig. 20 B).

\section{MDA and chemical antioxidants quantification}

Malondialdehyde (MDA) leaf contents showed no statistically significant variation in cultivars BGV001191, BGV 001581, or BGV004161, and displayed fluctuations not related to the concentration of salt applied in the remaining cultivars. The only significant increase was registered in plants of the cultivar BGV015856 subjected to $150 \mathrm{mM} \mathrm{NaCl}$ (Fig. 21). 
Fig. 20. Monovalent cation content variation in response to salt stress in the six cultivars of common beans analysed; (A) Sodium; (B) Potassium.

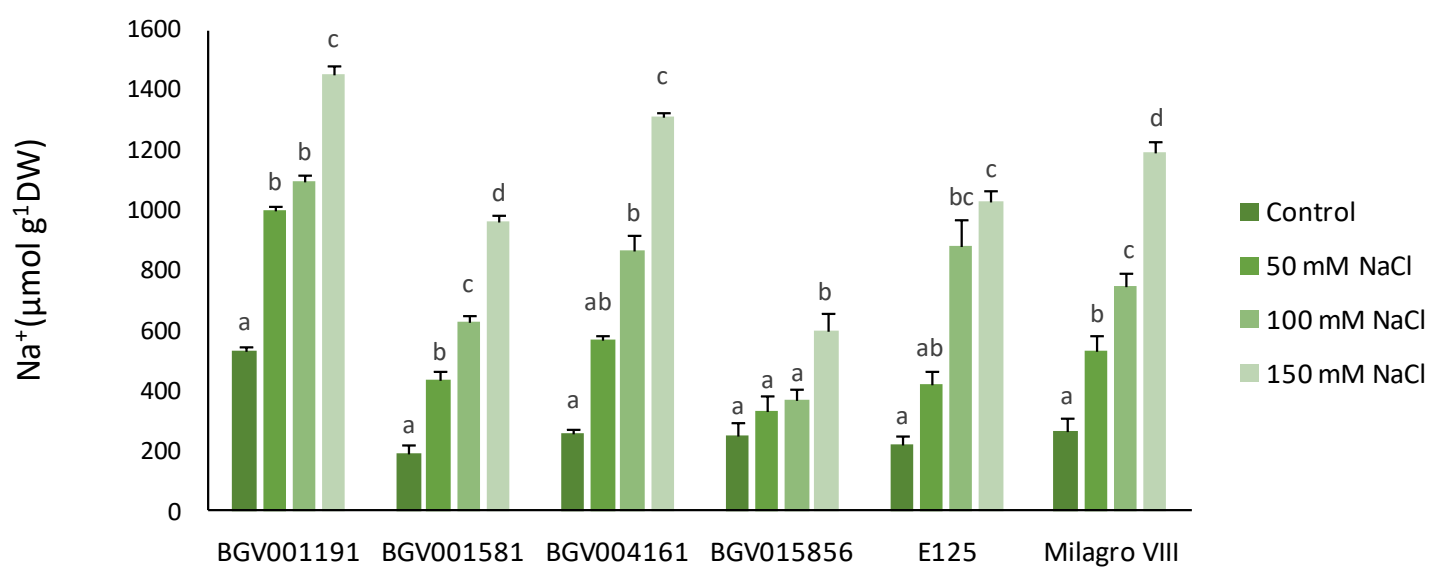

A

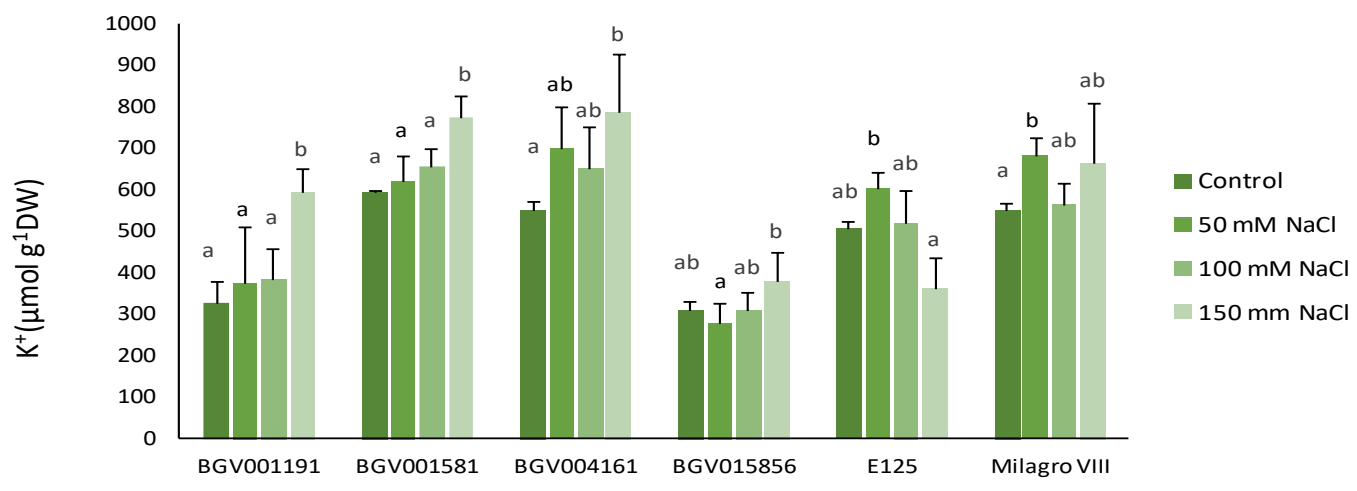

B

Mean \pm SE values are shown $(n=5)$. Same lowercase letters within each column indicate homogeneous groups between treatments according to the Tukey test $(p<0.05)$.

Fig. 21. Malondialdehyde content variation in response to salt stress in the six cultivars of common beans analysed

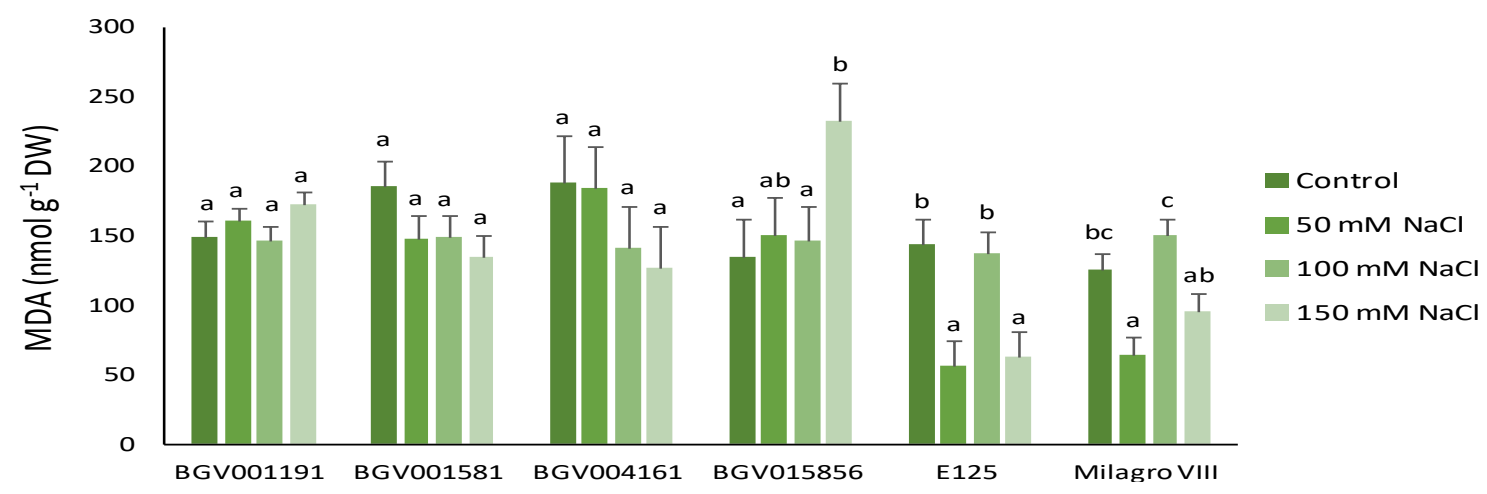

Note: Mean \pm SE values are shown $(n=5)$. Same lowercase letters within each column indicate homogeneous groups between treatments according to the Tukey test $(p<0.05)$. 
The antioxidant compounds analysed in the present work were the total phenolic compounds (TPC) and total flavonoids (TF). The first presented a variation that could not be correlated with the levels of salinity applied to the plants. In general, the highest levels of TPC were found in control plants, except for cultivar BGV004161, where values were slightly higher in plants from the $50 \mathrm{mM} \mathrm{NaCl}$ treatment (Fig. 22 ¡Error! No se encuentra el origen de la referencia.A). In the case of TF, compared to the non-stressed controls, a decrease under salt stress was observed in cultivars BGV001191 and BGV004161, no variation was found in BGV015856, and an increase was detected in BGV001581, E125 and Milagro VIII. However, only in the latter cultivar, the increase was gradual, in parallel to the rise in the concentration of $\mathrm{NaCl}$ (Fig. 22 B).

Fig. 22. Variation in antioxidant compounds contents in response to salt stress in the six cultivars of common beans analysed; (A) Total phenolic compounds; (B) Total flavonoids

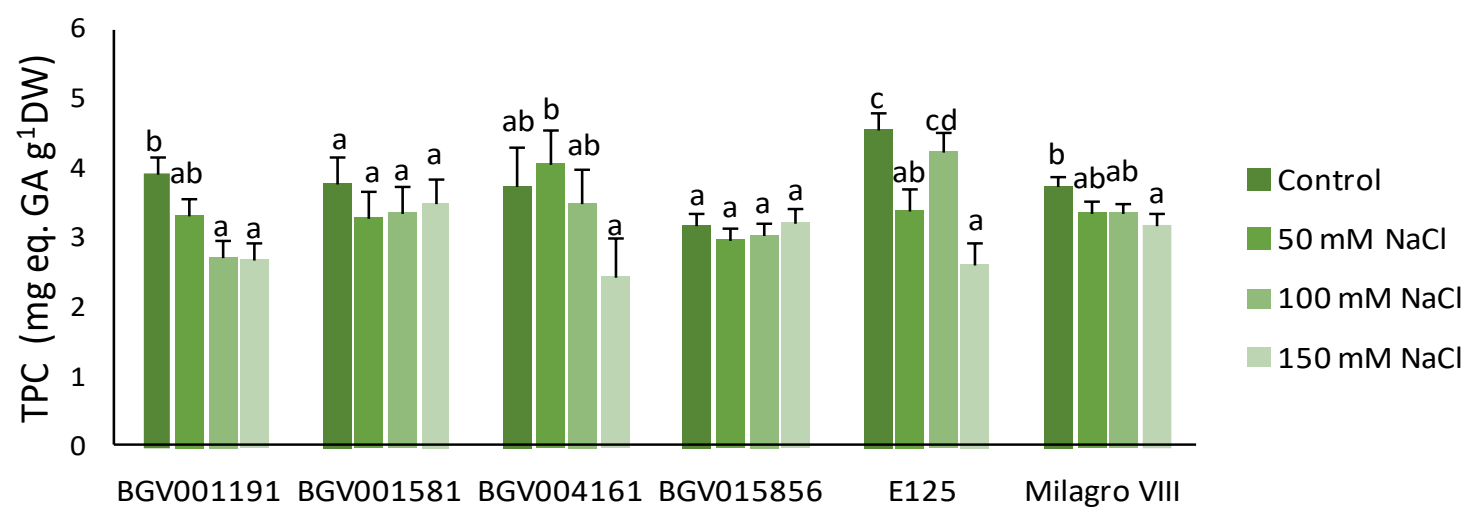




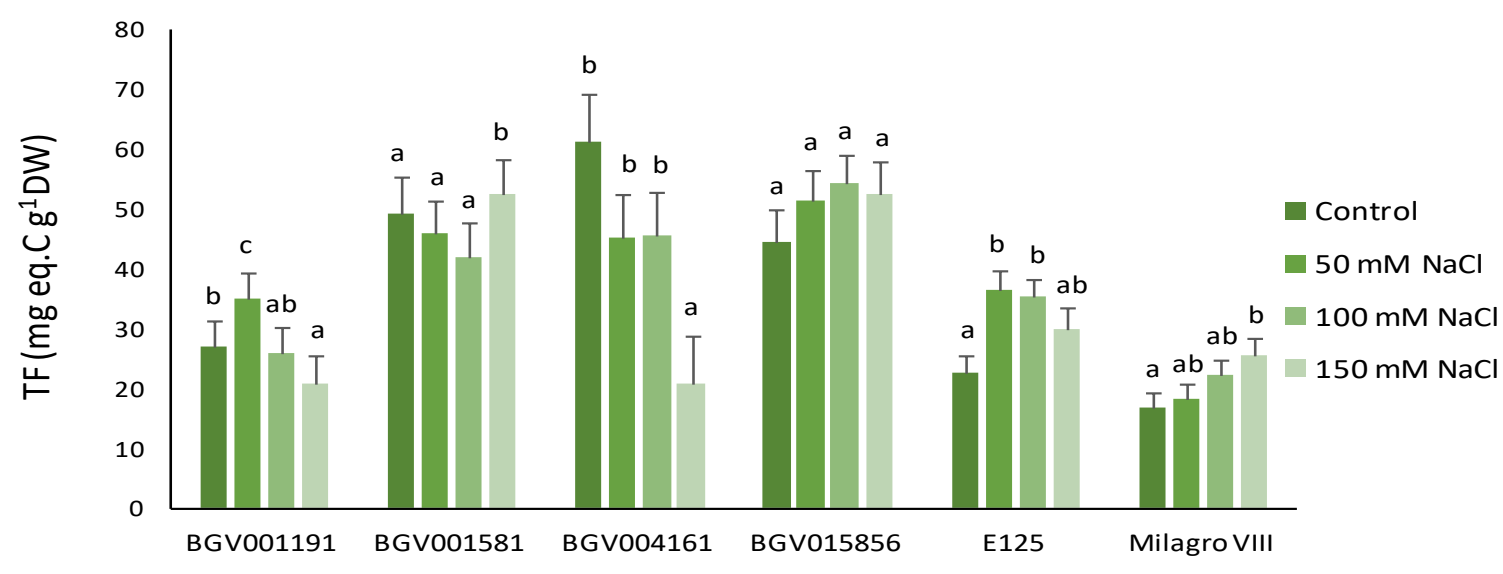

B

\section{Factorial ANOVA}

A two-way ANOVA was performed considering the effect of cultivar, treatment and their interaction. The effect of cultivar was significant for all parameters analysed, except for total phenolic compounds (TPC), and that of treatment for all traits evaluated except malondialdehyde (MDA) and total flavonoids (TF). Regarding the interaction of the two factors, it was significant for all parameters, except for $\mathrm{Na}^{+}$, which showed a similar pattern of variation, increasing in all cultivars under salt stress, although its concentrations were different between treatments. The statistical analysis confirmed the previous observation, revealing that osmolytes and monovalent cations are reliable stress parameters and at the same time, allow a proper differentiation of cultivars. Of these categories, proline and potassium are optimal according to their lower residual values.

Table 16. Percentages of the sum of squares (SS) from the two-way analysis of variance (ANOVA) of cultivar, treatment, and their interactions, for the indicated parameters.

\begin{tabular}{ccccc}
\hline Parameter & Cultivar $(\mathrm{C})$ & Treatment $(\mathrm{T})$ & Interaction $(\mathrm{C} \times \mathrm{T})$ & Residual \\
\hline Pro & $21.63 * * *$ & $44.57^{* * *}$ & $11.57 * * *$ & 22.24 \\
TSS & $13.43^{* * *}$ & $24.73 * * *$ & $17.08 * *$ & 44.74 \\
Na+ & $21.17^{* * *}$ & $42.93 * * *$ & 4.82 & 31.08 \\
K+ & $57.88^{* * *}$ & $6.19 * * *$ & $10.83 * * *$ & 25.10 \\
MDA & $24.43 * * *$ & 3.33 & $26.86^{* * *}$ & 45.38 \\
TPC & 6.55 & $14.53 * * *$ & $18.32 *$ & 60.58 \\
TF & $48.26 * * *$ & 1.25 & $15.95 * * *$ & 34.52 \\
\hline
\end{tabular}

$* * * * *$, and * indicate significant at $p<0.001, p<0.01$, and $p<0.05$, respectively 


\subsubsection{Discussion}

The six cultivars investigated here were the subject of a previous study regarding salt and drought tolerance in a large number of cultivars (Arteaga et al., 2020). Out of the 47 cultivars analysed in the previous work, BGV004161 and BGV015856 appeared as more stress-tolerant and were characterised by reduced levels of proline under stress, whereas the cultivar E125 was one of the most susceptible to stress and showed a significant increase of proline under both water and salt stress. The results reported here confirmed that the more tolerant genotypes identified in our previous study were those that experimented the smallest increase in the concentration of proline in leaves in response to increasing salinity. Proline is one of the commonest compatible solutes accumulated by plants under different types of stress (Szabados and Savouré, 2010; Grigore et al., 2012). Besides its essential role in osmotic adjustment as an osmolyte, Pro also has a function in osmoprotection, by directly stabilising sub-cellular structures such as membranes and proteins, in free-radical scavenging or as a signalling molecule in stress responses (Hayat et al., 2012; Kavi Kishor et al., 2014; Rana et al., 2017). Proline accumulation has been reported in beans under different stressful conditions, from the presence of herbicides (Mackay et al., 1990) or heavy metals (Zengin and Munzuroglu, 2005) to drought (Ashraf and Iram, 2005; Rosales et al., 2012; Morosan et al., 2017) and salinity (Jiménez-Bremont et al., 2006; Nagesh and Devaraj, 2008; Al Hassan et al., 2016). Higher Pro levels were reported in the more stress-tolerant cultivars in several studies comparing two or a few cultivars (Misra and Gupta, 2005; Cárdenas-Avila et al., 2006; Kaymakonova and Stoeva, 2008; Herrera Flores et al., 2012; Ghanbari et al., 2013), whereas others, based on a larger number of cultivars, revealed higher Pro levels in the more susceptible ones (Domínguez et al., 2014; Arteaga et al., 2020). In the present study, the levels of Pro increased with increasing salinity in all cultivars, but its absolute values were lower in the more salt-resistant 
BGV004161 and BGV015856 cultivars. On the contrary, Pro contents were higher, and the increase more pronounced, in the remaining four cultivars, which in the previous analysis were ranked as more susceptible to stress.

Total soluble sugars (TSS) play an essential role in osmotic adjustment under stress in many plant species and act as signalling molecules regulating the expression of different genes involved in photosynthesis, sucrose metabolism and osmolyte biosynthesis (Rosa et al., 2009). However, as TSS are direct products of photosynthesis and are involved in many metabolic processes, their specific role in stress tolerance is sometimes difficult to be assessed (Gil et al., 2011). Salinity was reported to increase levels of TSS in leaves (Abdallah et al., 2016) and in fruits after ripening (Yin et al., 2010) in different species. Although there is no clear correlation between TSS and the salt treatments applied (Al Hassan et al., 2016), leaf concentrations of some specific sugars considerably increased under stress in different bean cultivars, such as glucose and inositol (Bahena-Betancour et al., 2006) myo-inositol (Al Hassan et al., 2016). Accumulation of sucrose and starch in the pericarp has also been observed (Tazuke et al., 2009). In this study, a gradual increase of TSS in parallel to the concentration of $\mathrm{NaCl}$ has been detected only in the stress susceptible cultivar E125. For a better understanding of the TSS variation in this cultivar, separation, identification and quantification of individual soluble carbohydrates, for example by HPLC analysis, would be required to provide a more in-depth insight.

An essential mechanism related to salt stress responses is ion absorption and transport. The primary response in glycophytes in conditions of high soil salinity is generally blocking the transport of toxic $\mathrm{Na}^{+}$ions from roots to aboveground organs, contrary to dicotyledonous halophytes, which usually actively transport the ions to the leaves and accumulate them in their vacuoles as cheap osmotica (Flowers et al., 1986; Flowers and Colmer, 2008). It is known that plants of the genus Phaseolus can 
exclude sodium from the shoots, even in the presence of relatively high $\mathrm{NaCl}$ concentrations in the soil (Seemann and Critchley, 1985; Bayuelo-Jiménez et al., 2012), and that mechanisms that restrict the transport of $\mathrm{Na}^{+}$to the aerial part of the plants are more efficient in the relatively more tolerant cultivars (Al Hassan et al., 2016). This seems to be also the case of the more stress-resistant cultivar BGV015856 analysed here, which showed the lowest levels of $\mathrm{Na}^{+}$under salt stress. Sodium accumulation is generally associated with a drop in $\mathrm{K}+$ levels, mostly due to the competition of the two cations for the same membrane transport systems (Tester and Davenport, 2003). Potassium is regarded as the 'physiological' cation, whose deficiency has adverse effects on photosynthesis, protein biosynthesis and turgor driven movements (Gierth and Mäser, 2007). However, in all cultivars included in the present study, except for the most salt-sensitive E125, $\mathrm{K}+$ leaf contents did not decrease with increasing external salinity, even rose significantly over control levels at high salt concentrations. Maintaining relatively high cellular $\mathrm{K}+$ concentrations under salt stress conditions is a well-known fundamental mechanism of tolerance (Shabala and Cuin, 2007). Increased $\mathrm{K}^{+}$in foliar tissue is the result of the activation of $\mathrm{K}^{+}$transport to the leaves at high salinity, which may be regarded as an important mechanism of tolerance in this species as in many others (Volkov et al., 2003; Schiop et al., 2015; Kozminska et al., 2018).

Salinity, like other types of stress, is usually associated with secondary oxidative stress. MDA, a final product of membrane lipid peroxidation is considered as a reliable marker of oxidative stress (Del Rio et al., 2005), as one of the symptoms of oxidative damage is cell membrane degradation. However, no significant increase in MDA was detected in salt-treated plants, with the exception of plants from the 150 $\mathrm{mM} \mathrm{NaCl}$ treatment of cultivar BGV015856, indicating that generally they were not affected by salt-induced oxidative stress. These results suggest that, under the specific conditions of our experiments, possible mechanisms of tolerance based on 
the activation of antioxidant systems are not relevant in the analysed cultivars. This would explain the lack of correlation of TPF and TF contents with the relative salt tolerance of the tested cultivars and the concentrations of salt applied. In other bean cultivars and under different conditions, however, there is evidence that these secondary metabolites may increase in response to abiotic stress treatments (Taibi et al., 2016; Rahma et al., 2019.

\subsubsection{Conclusion}

Proline is a reliable marker of salt stress in common beans, its leaf contents increasing to higher levels in the more stress-susceptible cultivars. One of the main mechanisms conferring a relative salt resistance to common beans appears to be the active transport of potassium to leaves, maintaining its levels stable or even increasing in response to salt stress, thus partly compensating the deleterious effects of toxic $\mathrm{Na}+$ accumulation. This mechanism contributed to the relatively higher tolerance of two local landraces from Spain as compared to the other cultivars analysed in the present work. However, under the specific salt stress treatments applied to the plants, tolerance mechanisms based on the activation of antioxidant systems are not relevant since no secondary oxidative stress was generated.

\section{Authors' Contributions}

Conceptualisation: MB and OV; Data curation: SA; Formal analysis: JP; Funding acquisition; OV; Investigation: SA; Methodology: SA, OV; Project administration OV; Resources: OV and MB; Software: JP; Supervision: $M B$ and OV; Validation: JP; Visualisation: SA; Writing - original draft: SA and MB; Writing - review and editing: JP and OV. All authors read and approved the final manuscript.

\section{Acknowledgements}

Acknowledgements. This research received no specific grant from any funding agency in the public, commercial, or not-for-profit sectors.

\section{Conflict of Interests}

The authors declare that there are no conflicts of interest related to this article. 


\section{References}

Abdallah M.M.S., Abdelgawad Z.A., El-Bassiouny H.M.S. (2016). Alleviation of the adverse effects of salinity stress using trehalose in two rice varieties. South African Journal of Botany 103: 275-282

Al Hassan M, Morosan M., López-Gresa M.P., Prohens J., Vicente O., Boscaiu M. (2016). Salinity-induced variation in biochemical markers provides insight into the mechanisms of salt tolerance in common (Phaseolus vulgaris) and runner (P. coccineus) beans. International Journal of Molecular Sciences 17:1582. doi: $10.3390 /$ ijms 17091582

Apel K., Hirt H. (2004). Reactive oxygen species: metabolism, oxidative stress, and signal transduction. Annual Review of Plant Biology 55:373-399

Arteaga S., Yabor L, Díez M.J., Prohens J., Boscaiu M., Vicente O. (2020). The use of proline in screening for tolerance to drought and salinity in common bean (Phaseolus vulgaris L.) genotypes. Agronomy 10, 817. https: / doi.org/10.3390/agronomy10060817

Arteaga S., Yabor L., Torres J., Solbes E., Muñoz E., Díez M.J. ... Boscaiu M. (2019). Morphological and agronomic scharacterisation of Spanish landraces of Phaseolus vulgaris L. Agriculture 9:149. doi: 10.3390/agriculture9070149

Ashraf M., Iram A. (2005). Drought stress induced changes in some organic substances in nodules and other plant parts of two potential legumes differing in salt tolerance. Flora 200:535-546. doi: 10.1016/j.flora.2005.06.005.

Bahena-Betancourt L., Macias-Rodríguez L., Bayuelo-Jiménez J.S. (2006). Contents of carbohydrates in salt-stressed Phaseolus species; Annual Report of the Bean Improvement Cooperative; United States Department of Agriculture: Fort Collins, CO, USA, 2006; pp. 233-234.

Bates L.S., Waldren R.P., Teare I.D. (1973). Rapid determination of free proline for water stress studies. Plant and Soil 39:205-207. doi: 10.1007/BF00018060.

Bayuelo-Jiménez J.S., Jasso-Plata N., Ochoa I. (2012). Growth and physiological responses of Phaseolus species to salinity stress. International Journal of Agronomy 80:207-222.

Blainski A., Lopes G.C., Palazzo de Mello J.C. (2013). Application and analysis of the Folin Ciocalteu method for the determination of the total phenolic content from Limonium brasiliense L. Molecules 18:6852-6865. doi: $10.3390 /$ molecules 18066852 .

Broughton W.J., Hernández G., Blair M., Beebe S., Gepts P., Vanderleyden J. (2003). Beans (Phaseolus spp.)-Model food legumes. Plant and Soil 252: 55-128. doi: $10.1023 / \mathrm{A}: 1024146710611$

Cárdenas-Avila M., Verde-Star J., Maiti R., Foroughbakhch R., Gámez-González H., Martínez-Lozano S., ... Morales-Vallarta M. (2006). Variability in accumulation 
of free proline on in vitro calli of four bean (Phaseolus vulgaris L.) cultivars exposed to salinity and induced moisture stress. Phyton 75: 103-108.

Daliakopoulos I.N., Tsanis I.K., Koutroulis A.G., Kourgialas N., Varouchakis E.A., Karatzas G.P., Ritsema C.J. (2016). The threat of soil salinity: A European scale review. Science of Total Environment 573:727-739

Del Río L.A., Palma J.M., Sandalio L.M., Corpas F.J., Pastori G.M., Bueno P., LópezHuertas E. (1996). Peroxisomes as a source of superoxide and hydrogen peroxide in stressed plants. Biochemical Society Transactions 24:434-438.

Domínguez A., Yunel-Pérez Y., Alemán S., Sosa M., Fuentes L., Darias R... Sosa D. (2014). Respuesta de cultivares de Phaseolus vulgaris L. al estrés por sequía. Biotecnologia Vegetal 14:29-36.

Dubois M., Gilles K.A., Hamilton J.K., Reberd P.A., Smith F. (1956) Colorimetric method for determination of sugars and related substances. Analytical Chemistry 28:350-356. doi: 10.1021/ac60111a017.

Dwivedi S.L., Ceccarelli S., Blair M.W., Upadhyaya H.D., Are A.K., Ortiz R. (2016). Landrace germplasm for improving yield and abiotic stress adaptation. Trends in Plant Scence. 21:31-42. doi: 10.1016/j.tplants.2015.10.012

Fita A, Rodríguez-Burruezo A., Boscaiu M., Prohens J., Vicente O. (2015). Breeding and domesticating crops adapted to drought and salinity: A wew paradigm for increasing food production. Frontiers in Plant Science 6:978. doi: $10.3389 /$ fpls.2015.00978.

Flowers T.J., Colmer T.D. (2008). Salinity tolerance in halophytes, New Phytologist 179:945-963.

Flowers T.J., Hajibagheri M.A., Clipson N.J.W. (1986). Halophytes. The Quarterly Review of Biology 61:313-335

Gama P., Inanaga S., Tanaka K., Nakazawa R. (2007). Physiological response of common bean (Phaseolus vulgaris L.) seedlings to salinity stress. African Journal of Biotechnology 6:79-88.

Gepts P., Debouck D.G. (1991). Origin, domestication, and evolution of the common bean, Phaseolus vulgaris. In: Common Beans: Research for Crop Improvement; Van Schoonhoven, A., Voysest, O., Eds; Cab Intern, Wallingford, UK, pp 7-53.

Ghanbari A.A., Mousavi S.H., Mousapou-Gorji A., Rao I. (2013). Effects of water stress on leaves and seeds of bean (Phaseolus vulgaris L.). Turkish Journal of Field Crops 18:73-77.

Gierth M., Mäser P. (2007). Potassium transporters in plants- Involvement in $\mathrm{K}^{+}$ acquisition, redistribution and homeostasis. FEBS Letters:581:2348-2356. PMID: 1739783

Gil R., Boscaiu M.T., Lull C., Bautista I., Lidón A.L., Vicente O. (2013). Are soluble carbohydrates ecologically relevantfor salt tolerance in halophytes? Functional Plant Biology. 40:805-818.doi:10.1071/FP12359 
Grigore M.N., Boscaiu M., Vicente O. (2011). Assessment of the relevance of osmolyte biosynthesis for salt tolerance of halophytes under natural conditions. European Journal of Plant Science and Biotechnology 5: 12-19.

Hasegawa P.M., Bressan R.A., Zhu J.K., Bohnert H.J. (2000) Plant cellular and molecular responses to high salinity. Annual Review of Plant Biology 51:463-99. doi: 10.1146/annurev.arplant.51.1.463

Hayat S., Hayat Q., Alyemeni M.N., Wani A.S., Pichtel J., Ahmad A. (2012). Role of proline under changing environments: a review. Plant Signaling and Behaviour 7:1456-1466. doi: https://doi.org/10.4161/psb.21949.

Herrera-Flores T.S., Ortíz-Cereceres J., Delgado-Alvarado A., Acosta-Galleros J.A. (2012). Growth and, proline and carbohydrate content of bean seedlings subjected to drought stress. Revista Mexicana de Ciencias Agrícolas 3, 713725.

Hoagland D.R., Arnon D.I. (1950). The water culture method for growing plants without soil. California Agricultural Experimental Station Circular No. 347, pp. 1-32. University of California, Berkeley.

Hodges D.M., De Long J.M., Forney C.F., Prange R.K. (1999). Improving the thiobarbituric acid-reactive-substances assay for estimating lipid peroxidation in plant tissues containing anthocyanin and other interfering compounds. Planta 207:604-611. doi: 10.1007/s004250050524.

Hurtado M., Vilanova S., Plazas M., Gramazio P., Andújar I., Herraiz F.J., Prohens J. (2014). Enhancing conservation and use of local vegetable landraces: the Almagro eggplant (Solanum melongena L.) case study. Genetic Resources and Crop Evolution 61:787-795. https://doi.org/10.1007/s1 0722-013-0073-2

Hussain T.M., Chandrasekhar T., Hazara M., Sultan Z., Saleh B.K., Gopal G.R. (2008) Recent advances in salt stress biology - a review. Biotechnology and Molecular Biology Reviews 3(1):008-013.

Jiménez-Bremont J.F., Becerra-Flora A., Hernández-Lucero E., Rodríguez-Kessler M. Acosta-Gallegos J., Ramírez-Pimentel J. (2006). Proline accumulation in two bean cultivars under salt stress and the effect of polyamines and ornithine. Biologia Plantarum 50:763-766. doi: 10.1007/s10535-006-0126-x

Kavi-Kishor P., Sreenivasulu N. (2014). Is proline accumulation per se correlated with stress tolerance or is proline homeostasis a more critical issue? Plant Cell and Environment 37:300-311. doi: 10.1111/pce.12157

Kaymakanova M., Stoeva N (2008). Physiological reaction of bean plants (Phaseolus vulgaris L.) to salt stress. General and Applied Plant Physiology 34:177-188.

Kozminska A., Al Hassan M., Hanus-Fajerska E., Naranjo M.A., Boscaiu M., Vicente O. (2018). Comparative analysis of water deficit and salt tolerance mechanisms in Silene. South African Journal of Botany 117:193-206 
Mackay C.E., Hall C., Hofstra G., Fletcher R.A. (1990). Uniconazole-induced changes in abscisic acid, total amino acids, and proline in Phaseolus vulgaris. Pesticide Biochemistry and Physiology 37:74-82.

Mercer K.L., Perales H.R. (2010). Evolutionary response of landraces to climate change in centers of crop diversity. Evol Appl. 3(5-6):480-493. doi:10.1111/j.17524571.2010.00137.x

Misra N., Gupta A.K. (2005). Effect of salt stress on proline metabolism in two high yielding genotypes of green gram. Plant Sci. 169, 331-339.

Morosan M., Al Hassan M., Naranjo M., Lopez-Gresa M.P., Vicente O. (2017). Comparative analysis of drought responses in Phaseolus vulgaris (common bean) and $P$. coccineus (runner bean) cultivar. EuroBiotech J. 1, 247-252. https: / / doi.org/10.24190/ISSN2564-615X/2017/03.09

Nagesh B., Devaraj V. (2008). High temperature and salt stress response in French bean (Phaseolus vulgaris). Austr. J. Crop Sci 2, 40-42.

Pinheiro C., Baeta J.P., Pereira A.M., Dominguez H.. Ricardo C. (2007). Mineral elements correlations in a Portuguese germplasm collection of Phaseolus vulgaris. Integrating Legume Biology for sustainable Agriculture. In Proceedings of the 6th European Conference on Grain Legumes, Lisboa, pp. 125-126.

Rahma Laredj-Zazou R., Toumi-Benali F., Tifouri Z. (2019). Phytochemical potential and antioxidant activity of Phaseolus vulgaris L. (Var, Sidi Ferredj) in the face of salt stress. South Asian Journal of Experimental Biology, Vol 9, No 2

Rana V., Ram S., Nehra K. (2017). Proline biosynthesis and its role in abiotic stress. Int. J. Agric. Res. Innov. Technol., 6, ISSN (Online) 2319-147

Raza A., Razzaq A., Zou X., Mehmood S., Zhang X., Yan L.V., Jinsong Xu. (2019). Impact of Climate Change on Crops Adaptation and Strategies to Tackle Its Outcome: A Review. Plants (Basel) 8(2): 34. doi: 10.3390/plants 8020034

Rendón-Anaya M., Montero-Vargas J.M., Saburido-Álvarez S. et al. (2017) Genomic history of the origin and domestication of common bean unveils its closest sister species. Genome Biol. 2017, 18, 60. https://doi.org/10.1186/s13059017-1190-6

Rosa M., Prado C., Podazza G., Interdonato R., González J.A., Hilal M., Prado F.E. (2009). Soluble sugars-Metabolism, sensing and abiotic stress. A complex network in the life of plants. Plant Signaling \& Behavior 4:5, 388-393; doi: 10.4161 /psb.4.5.8294.

Rosales M.A., Ocampo O., Rodríguez-Valentín R., Olvera-Carrillo Y., Acosta-Gallegos J., Covarrubias A.A. (2012). Physiological analysis of common bean (Phaseolus vulgaris L.) cultivars uncovers characteristics related to terminal drought resistance. Plant Physiol. Biochem., 56, 24-34. doi: 10.1016/j.plaphy.2012.04.007. 
Schiop S.T., Al Hassan M., Sestras A.F.,Boscaiu M., Sestras R.E., Vicente O. (2015). Identification of Salt Stress Biomarkers in Romanian Carpathian Populations of $\begin{array}{lllll}\text { Picea } & \text { abies(L.) Karst.PLoS ONE 10(8): } & \text { e0135419. }\end{array}$ doi:10.1371/journal.pone.0135419.

Seemann J.R., Critchley C. (1985). Effects of salt stress on the growth, ion content, stomatal behaviour and photosynthetic capacity of a salt-sensitive species, Phaseolus vulgaris L. Planta 164, 151-162.

Shabala S., Cuin T.A. (2007). Potassium transport and plant salt tolerance. Physiol Plant. 133:651-669.

Szabados L., Savouré A. (2010). Proline: A multifunctional amino acid. Trends Plant Sci. 15, 89-97. doi: https://doi.org/10.1016/j.tplants.2009.11.009.

Taïbi K., Taïbi F., Abderrahima L.A. Ennajah A. Belkhodja M. Mulet J.M. (2016). Effect of salt stress on growth, chlorophyll content, lipid peroxidation and antioxidant defence systems in Phaseolus vulgaris L. South African Journal of Botany 105, Pages 306-312.

Tazuke A., Wada T., Kanazawa T. (2009). Effects of $\mathrm{NaCl}$ salinity on the sugar metabolism of common bean (Phaseolus vulgaris L.) cv. "Tsurunashi Marusaya Kurosando" fruit grown in solution culture. J. ISSAAS 15, 32-43.

Tester M., Davenport R., (2003). $\mathrm{Na}^{+}$tolerance and $\mathrm{Na}^{+}$transport in higher plants. Ann. Bot. 91, 503-527.Volkov V, Wang B, Dominy PJ, Fricke W, Amtmann A.Thellungiella halophila, a salt-tolerant relative of Arabidopsis thaliana, possesses effective mechanisms to discriminate between potassium and sodium. Plant Cell Environ. 27:1-14

Weimberg R. (1987). Solute adjustments in leaves of two species of wheat at two different stages of growth in response to salinity. PHYSIOL PLANTARUM 70:381-388. doi: 10.1111/j.1399-3054.1987.tb02832.x.

Yin Y. G., Kobayashi Y., Sanuki A., Kondo S., Fukuda N., Ezura H., Sugaya S., Matsukura, C. (2010). Salinity induces carbohydrate accumulation and sugarregulated starch biosynthetic genes in tomato (Solanum lycopersicum L. cV. 'Micro-Tom') fruits in an ABA- and osmotic stress-independent manner. Journal of Experimental Botany, 67(2), 563-574. https://doi.org/10.1093/jxb/erp333 
Discusión General

Capitulo IV. Discusión General 
Las plantas se pueden enfrentar a amplias condiciones de estrés ambiental, entre las que se incluyen las temperaturas extremas, sequía, salinidad, inundaciones, toxicidad, diversos estreses oxidativos, que pueden afectar negativamente el crecimiento y limitar que éstas alcancen su máximo potencial de crecimiento. Estas alteraciones abióticas afectan los entornos naturales y los rendimientos de los cultivos (Mahajan y Tuteja, 2005). El cambio climático es un desafío al que el sector agrícola se debe enfrentar. El aumento de las temperaturas puede llegar a reducir la cantidad y la calidad del agua. El agua es un recurso esencial para los ecosistemas y para el hombre, su uso está sometido a una presión cada vez mayor en diferentes partes del mundo. El cambio climático requiere de una gestión más sostenible del agua. Por otra parte, un efecto negativo en el desarrollo y la producción de cultivos son las inundaciones, por lo tanto, es importante seleccionar cultivos adecuados y controlar el agua del suelo mediante estrategias de manejo agronómico apropiadas.

Alteraciones en las temperaturas también representan problemas para el sector agropecuario, por ej. el estrés por heladas puede ocasionar daños en flores y frutos en formación y por ende bajos rendimientos en los cultivos, altas o bajas irradiaciones pueden tener impactos directos en la biomasa de los cultivos y la calidad de los mismos, puesto que los procesos de la fotosíntesis y respiración están intimidante relacionadas con la temperatura, la intesidad de la luz y su calidad. En zonas áridas y semiáridas, aunque el riego ayuda aumentar la productividad, sobre la explotación de los sistemas de riego, el manejo de plantas arvenses y algunas prácticas agrícolas mal realizadas conducen a la salinización del suelo. Actualmente, casi el $20 \%$ de todas las tierras cultivadas y de regadío (equivalentes a 62 millones de ha) están afectadas negativamente por la sal, y algunas estimaciones Ilegan hasta el 50\% (Khan et al., 2015).

El trabajo de investigación que permite determinar la resistencia a la salinidad de Phaseolus lunatus L. en cuatro variedades locales de España, es el primero que 
informa sobre los efectos de la sal en el cultivo; y su importancia radica en que la salinidad es uno de los factores ambientales que más limita la productividad en los cultivos, ya que altas concentraciones en el suelo los hace sensibles y causa pérdidas económicas al sector agrícola. A su vez este estudio puede contribuir al desarrollo de una selección eficiente de métodos para seleccionar genotipos de Phaseolus relativamente tolerantes a la salinidad en beneficio de los mejoradores y agricultores con el fin de ayudar a preservar la diversidad genética del cultivo.

Las plantas glicofitas reducen su crecimiento cuando sufren estrés por la presencia de sal en el suelo, mientras que las halofitas son tolerantes a la sal y las plantas dicotiledóneas en algunos casos pueden llegar a tolerar concentraciones muy bajas con valores inferiores a $50 \mathrm{mM}$ de $\mathrm{NaCl}$ (Glenn, 1987; Glenn et al., 1999). Para hacer frente al estrés por salinidad, las plantas han desarrollado diferentes estrategias de adaptación, que se superponen parcialmente con las respuestas al estrés por sequía, e incluyen una reducción de la pérdida de agua mediante la regulación del cierre de los estomas, la reducción del crecimiento y la protección del estrés iónico (Munns \& Tester, 2008).

Según Zörb (2018) la tolerancia a la salinidad varía entre cultivares. Asimismo, la tolerancia de los cultivos a la sal puede variar con su etapa de crecimiento (Maas y Grieve, 1994). Algunos cultivos de cereales y leguminosas, como el sorgo, maíz, cebada, arroz, caupi y el trigo, son tolerantes a la salinidad en la germinación, pero sensibles en las plántulas y en las primeras etapas de crecimiento vegetativo, pero nuevamente se vuelven tolerantes en la madurez (Akbar \& Yabuno, 1977; Ashraf, 1994). Estas razones nos llevan a realizar estudios en cuatro accesiones de $P$. Iunatus con el fin de conocer la tolerancia de sal en estos cultivares locales. De los cuatro genotipos de $P$. Iunatus analizados en este estudio, el cultivar BGV-15410 demostró ser el más tolerante a la sal, mientras que el VPH-79 fue el más sensible al estrés salino. Los efectos del estrés salino se observaron con mayor claridad en hojas, en 
dónde mostraron reducciones significativas en su número y peso fresco, esto coincide con estudios realizados por Thuzar et al., 2011 dónde investiga sobre la tolerancia a salinidad de cuatro cultivares de Vigna, con concentraciones de $\mathrm{NaCl}(0$, 75, 150 y 225 mM en la etapa de plántula y observó que el estrés salino inhibió casi todos los parámetros de crecimiento, así como en el contenido hídrico; sin embargo el grado de reducción dependió en gran medida de los genotipos y niveles de salinidad.

Por otra parte, los porcentajes del contenido hídrico en el cultivar BGV-12848 no disminuyó, lo que indica la presencia de mecanismos eficientes que evitan la deshidratación inducida por la sal, contrarrestando el estrés osmótico generado por la salinidad; por lo tanto, la reducción del crecimiento probablemente se debió al componente de "toxicidad iónica" provocada por exceso de sales. En un intento por identificar los mecanismos responsables de la tolerancia a la sal en esta especie, las concentraciones de varios marcadores bioquímicos asociados con vías de respuestas específicas fueron determinadas en plantas con tratamiento de Control y Salinidad en esta especie. Algunos autores informan sobre la disminución en la concentración de clorofila en muchas especies de leguminosas bajo condiciones de alta salinidad (Taffouo et al., 2010; Taibi et al., 2016); esto se debe tanto a la inhibición de las enzimas asociadas con la síntesis de clorofila como a la activación de la clorifilasa responsable de su degradación (Soussi et al., 1998; Santos, 2004). Sin embargo, en nuestro estudio no se detectaron cambios significativos en las concentraciones de clorofila en ninguno de los cuatro cultivares de $P$. lunatus. Por otro lado los carotenoides tuvieron una reducción significativa en los cv más sensibles a la sal VPH-79, pero no varió en BGV-12848 y BGV-15410 y aumentó en BGV-1588. La ausencia de variación en el contenido de clorofila no significa tolerancia a la sal, ya que otros factores (que no se consideran en este estudio) pueden resultar en una disminución significativa del número de hojas y biomasa observada en los cultivares 
más sensibles. No obstante, la falta de degradación de la clorofila inducida por la sal observada en este experimento probablemente se debe a una mayor resistencia a la salinidad de $P$. lunatus en comparación con otras especies de leguminosas. La resistencia a la salinidad en varias especies de Phaseolus y también en diferentes cultivares de $P$. vulgaris, se ha asociado con la exclusión de iones $\left(\mathrm{Na}^{+} \mathrm{y} \mathrm{Cl}^{-}\right)$en la parte aérea de las plantas, así como con el mantenimiento de concentraciones estables de K+ en las hojas (Gil et al., 2014; Jacobi, 1964; Kramer et al, 1977; Seeman \& Critchley, 1985; Bayuelo-Jimenez et al., 2012; Gama et al., 2007; Al Hassan et al., 2016). El potasio se considera uno de los cationes "fisiológicos" esenciales para el metabolismo, el crecimiento y desarrollo de las plantas (Gierth \& Mäser, 2007), mientras que las altas concentraciones de $\mathrm{Na}^{+}$tienen efectos nocivos sobre las plantas no halófitas, inhibiendo muchas actividades enzimáticas y procesos celulares (Rodriguez-Navarro \& Rubio, 2006; Adams \& Shin, 2014). Además, un incremento de las concentraciones de $\mathrm{Na}^{+}$generalmente se asocia con una reducción de $\mathrm{K}^{+}$, ya que ambos cationes compiten entre ellas mismas y el $\mathrm{Na}^{+}$reduce la absorción de $\mathrm{K}+$ en la célula mediante el transporte de proteínas en la membrana. Muchas plantas tolerantes a la sal pueden mantener altas concentraciones de $\mathrm{K}^{+}$cuando se exponen a la salinidad, como se ha descrito, por ejemplo, en Thellungiella halophila, un pariente de la glicofita Arabidopsis thaliana tolerante a la sal (Volkow et al., 2003). La concentración de $\mathrm{K}^{+}$en hojas se mantuvieron o incrementaron, especialmente a altas concentraciones de sal, en respuesta a los tratamientos de sal en los cultivares de frijol lima analizados aquí. Curiosamente, las concentraciones de $\mathrm{K}^{+}$en el Control fueron altas en los cultivares BGV-15410 y BGV-1588, y a su vez fueron los cultivares más tolerantes a la salinidad. Un mayor contenido de $\mathrm{K}^{+}$en ausencia de sal puede ser un mecanismo de defensa innato, que podría permitir que estos dos cultivares se ajusten mejor a las condiciones de salinidad. Se puede afirmar que altas concentraciones de $\mathrm{K}^{+}$en hojas de plantas estresadas por sal se puede considerar 
como un mecanismo general de tolerancia en habas. Estos datos coinciden con el con el papel fundamental del $\mathrm{K}^{+}$en las respuestas de las plantas a la salinidad (y a otros estreses bióticos y abióticos), reiterando la necesidad de optimizar la fertilización de $\mathrm{K}^{+}$para evitar su deficiencia en el suelo (Wang et al., 2013) en este cultivo, así como para otros cultivos.

Los parámetros bioquímicos que claramente separan los cuatro cultivares estudiados fue la concentración de prolina que se midió en las hojas al finalizar los tratamientos de sal. La prolina es un osmolito en las plantas, que se acumula no solo en condiciones de estrés salino, sino también en respuesta a otros estreses abiótico como sequía, temperaturas extremas, deficiencias nutricionales, presencia de metales pesados, contaminación del aire o alta radiación ultravioleta, y en algunos casos a la infección por patógenos en plantas (Hare \& Cress, 1997; Saradhi et al., 1995; Siripornadulsil et al., 2002). Además de su papel clave en el ajuste osmótico celular bajo estrés, también está involucrado en la estabilización de estructuras macromoleculares, como membranas y proteínas (Siripornadulsil et al., 2002), y en libre captación de radicales (Verbruggen \& Hermans, 2008; Smirnoff \& Cumbes, 1989). En nuestro estudio, BGV-15410 y BGV -1588, mostraron la mayor tolerancia a la sal (considerando el grado relativo de inhibición del crecimiento), se registra significativamente que las concentraciones foliares de prolina fueron más altas al compararlas con los otros dos cultivares bajo estrés salino y condiciones de control.

No existe una correlación clara entre las concentraciones de prolina y la tolerancia al estrés en las especies del género Phaseolus. En la judía, algunos reportes detectan altas concentraciones de prolina en los cultivares más tolerantes (Cárdenas-Ávila et al., 2006), mientras que en otros los niveles más altos se encontraron en los cultivares más sensibles (Jiménez-Bremont et al., 2006). Al Hassan et al., (Al Hassan et al., 2016) en sus análisis sobre cultivares $P$. vulgaris, en los más tolerantes midió concentraciones más bajas de prolina y las concentraciones 
totales de prolina estaban muy por debajo de las determinadas en $P$. Iunatus en el presente trabajo. La prolina parece desempeñar un papel importante en el ajuste osmótico de las habas, y la mayor concentración de prolina presentes en los dos cultivares más tolerantes a la sal son probablemente responsables, al menos parcialmente para esta tolerancia.

Por otra parte, al analizar las accesiones de $P$. vulgaris, se destacó la gran variabilidad para la mayoría de las 32 características evaluadas. Se ha reportado en trabajos anteriores una alta diversidad en colecciones de judías de origen español (Gil \& De Ron, 1992; Rodiño et al., 2003). Es también evidente la diversidad de tipos en cuánto a tamaño, color y forma de las semillas, así como para otras características relacionadas con las principales diferencias entre los dos acervos genéticos, el mesoamericano y el andino; ellas incluyen el tamaño, y la forma de la hoja trifoliada terminal, bractéolas, la presencia o ausencia de líneas en la base del estandarte y la posición del pico de la vaina. Esta investigación coincide con los resultados obtenidos por otros autores que han demostrado que, en la Peninsula Iberica, después de siglos del cultivo ocurrió una mezcla de los dos grupos de germoplasma (Andino y Mesoamericano). Esto ya fue revelado, con base a estudios morfológicos, patrones de proteínas de faseolina y marcadores moleculares (Rodiño et al., 2003; Pérez-Vega et al., 2009). La existencia de ambos acervos supone un valor añadido para germoplasmas españoles. Esta alta variabilidad de accesiones españolas es de gran valor para su adaptación a las condiciones ambientales de ambas áreas de domesticación del cultivo. Además, se pueden utilizar como puente para la transferencia de genes entre accesiones pertenecientes a ambos grupos de genes, como ya ha sugerido Rodiño et al. (Rodiño et al., 2003).

Los análisis del clúster y PCA fueron congruentes, y las accesiones se separaron claramente por sus rendimientos y sus componentes, principalmente los relacionados con las vainas y semillas, así como el color de las semillas. Estas 
características son mucho más importantes para explicar la diversidad de tipos de judías en España, en contraste con otros rasgos relacionados con el crecimiento y precocidad de las plantas. La falta de agrupación de accesiones de diferentes orígenes refleja una falta de diferenciación regional, probablemente causada por el transporte por humanos e intercambio de semillas entre agricultores.

El alto número de características que presentan interacciones entre el genotipo y ambiente, cuando se cultiva en primavera y otoño, está de acuerdo con informes anteriores (Vaid et al., 1985; Escribano et al., 1994). También, Nienhuis et al., (Nienhuis $\&$ Singh, 1986) y Sill et al., (Sills $\&$ Nienhuis, 1993) reportaron efectos en el ambiente en la expresión de rasgos en diferentes tipos de judías. Esto significa que el mejor genotipo para un entorno puede no ser el mejor para otro y, por lo tanto, se deben desarrollar tipos específicos de frijoles para cultivo en diferentes entornos (Hosfield et al., 1984). En este ensayo, el principal factor ambiental diferencial entre las dos estaciones de crecimiento, otoño y primavera fue la radiación solar, mientras que la temperatura y la humedad relativa se controlaron en el invernadero. Aproximadamente el $50 \%$ de las accesiones no mostraron una gran variación en el rendimiento al comparar las dos estaciones. Sin embargo, las otras accesiones mostraron variación, la mayoría alcanzando mayores rendimientos en primavera, en la que la radiación solar favorece la fotosíntesis $y$, en consecuencia, la fotoasimilación, independientemente del origen geográfico de las accesiones. Las respuestas de las accesiones a los diferentes entornos que se evaluaron en este trabajo es de gran interés, ya que los resultados obtenidos se pueden trasladar a los programas de mejora genética.

Los valores de desviación estándar para el peso, la longitud y el ancho de la semilla fueron mayores que los reportados por Escribano et al. (Escribano et al., 1998), que estudió un conjunto de 66 variedades locales recolectadas en Galicia (España). Lo mismo ocurrió con los rasgos relacionados con las características 
vegetativas, como longitud (LeafL) y el ancho de la hoja (Wcshe), y otros rasgos de las vainas y semillas. El rango de variación para estos rasgos también fue mayor en el conjunto de accesiones estudiadas en el presente trabajo que en el germoplasma estudiado por Rodiño et al. (Rodiño et al., 2003), que consistió en un grupo de 388 cultivares recolectados en las principales regiones de producción de la Península Ibérica y una colección central de 52 accesiones construida a partir de un grupo de 388 cultivares. Esta alta fuente de variabilidad puede ser empleada para desarrollar variedades con características muy diferentes, adaptadas a diferentes entornos, y también adaptado a las preferencias del mercado, en ambos grupos de cultivares, con semillas blanquecinas y pardas, los cuáles son económicamente más interesantes.

Por otra parte, se realizaron estudios con el fin de analizar las respuestas a la sequía y la salinidad de 47 genotipos de diferentes orígenes de $P$. vulgaris. Se observó una gran variabilidad en los parámetros de crecimiento por individuos y también por su dispersión en los diagramas de PCA, lo que dificulta determinar a primera vista las variables que son más relevantes para evaluar el grado relativo de inhibición del crecimiento inducida por el estrés, y por lo tanto, para clasificar los diferentes cultivares según su sensibilidad o resistencia al estrés hídrico y salino. Sin embargo, los análisis estadísticos realizados con todos los datos experimentales proporcionaron una imagen general clara de las respuestas al estrés de los cultivares de P. vulgaris. Ambos, "cultivar" y "tratamiento", así como su interacción, tuvieron un efecto muy significativo en (prácticamente) todos los caracteres de crecimiento analizados, y en el contenido de prolina, para los tratamientos de dos y tres semanas tanto estrés hídrico como salino. En todos los casos, se observó una reducción del crecimiento en los caracteres del peso fresco y el contenido hídrico de los tallos (SFW y SWC) y hojas (LFW y LWC), como lo informaron en la misma especie (Al Hassan et al., 2016; Morosan et al., 2017) u otras especies de este género (Arteaga et al., 2018). 
Estos parámetros de crecimiento fueron los más correlacionados positiva y significativamente, en la primera componente principal del PCA. La prolina, por otro lado, fue la única variable que mostró una correlación negativa al medirla con las variables de crecimiento, pero particularmente con las de tallos y hojas mencionadas anteriormente, como lo indican los coeficientes de correlación de Pearson y las gráficas de los PCA.

Al comparar la tolerancia al estrés de taxones asociados, por ejemplo, diferentes cultivares de una especie en particular, las mediciones de los parámetros de crecimiento a menudo se complementan con la determinación de varios marcadores de estrés bioquímico, asociados con una mayor (o menor) tolerancia; incluyen solutos u osmolitos compatibles (Andrade et al., 2016; Bacha et al., 2017; Sen et al., 2017; Kozminska et al., 2019). La Prolina es un osmolito común en las plantas, que se acumula en respuesta a diferentes tipos de estrés abiótico, incluida la sequía y salinidad, en una variedad de especies de plantas (Szabados \& Savouré, 2010; Verbruggen \&Hermans, 2008; Grigore et al., 2011 ; Parvaiz \& Satyawati, 2008). Además de su papel en el ajuste osmótico celular, la Prolina tiene funciones adicionales como "osmoprotector" y es acumulado en condiciones de estrés en las plantas; estabiliza directamente las estructuras subcelulares, como membranas y proteínas, elimina los radicales libres que amortiguan el potencial redox, alivia la acidosis celular y actúa como una molécula de señalización en las respuestas al estrés (Hayat et al., 2012; Rana et al., 2017). La prolina también juega un papel esencial en ausencia del estrés, está involucrada en muchos procesos de desarrollo de la planta; por ejemplo, la concentración de prolina aumenta durante la maduración de polen y semillas. Sin embargo, la prolina puede ser toxico para ciertos tejidos si se cataboliza parcialmente a pirrolina-5-5-carboxilato (P5C), lo que conduce a la apoptosis (Kavi Kishor \& Sreenivasulu, 2014). Considerando las múltiples funciones que cumple la prolina, se asume que la acumulación de la prolina se asocia con una mayor tolerancia 
al estrés, y esto se ha demostrado en muchas plantas, tanto especies silvestres (Al Hassan et al., 2016; Al Hassan et al., 2016) como cultivos (Arteaga et al., 2018; Plazas et al., 2019). Sin embargo, otros estudios sobre taxones relacionados, especies del mismo género o cultivares y/o variedades de la misma especie, revelaron una mayor acumulación de prolina bajo estrés en los genotipos menos tolerantes (Chen et al., 2007 y Kozminska et al., 2018). Existe cierta confusión, que a menudo se encuentra en la literatura, entre los conceptos de "respuestas al estrés" y "tolerancia al estrés". Aunque los mecanismos de tolerancia al estrés se basan en respuestas al estrés, no todas las respuestas son relevantes a la tolerancia. En este orden de ideas, la acumulación de prolina se puede considerar como una "respuesta" general al estrés abiótico en muchas especies de plantas, pero la prolina puede o no estar involucrado en los mecanismos de tolerancia al estrés, según la especie.

La judía común es claramente una especie acumuladora de prolina, diversos estudios han reportado importantes aumentos en el contenido de la prolina en plantas de Phaseolus como respuesta a tratamientos bajo estrés salino (JiménezBremont et al., 2006; Al Hassan et al., 2016; Nagesh et al., 2008) y/o estrés hídrico (Morosan et al., 2017; Ashraf \& Iram, 2005; Rosales et al., 2012). Además, la prolina es un indicador en otros tipos de estrés en judías, como el inducido por una dosis excesiva de nitrógeno (Sánchez et al., 2001), herbicidas (Mackay et al., 1990) o metales pesados (Zengin \& Munzuroglu, 2005). Además, se demostró que la aplicación exógena de prolina alivia los efectos perjudiciales del estrés salino en judías (Abdelhamid et al., 2013). Sin embargo, algunas investigaciones se contradicen sobre la función de la prolina en los mecanismos de tolerancia al estrés en cultivares de Phaseolus. Algunos autores afirman que hay un mayor contenido de prolina en cultivares más tolerantes a la sequía (Kapuya et al., 1985; Herrera-Flores et al., 2012; Ghanbari et al., 2013; Kusvuran \& Dasgan, et al., 2017; Wang et al., 2019) o tolerantes a la sal (Misra et al., 2005; Cardena-Avila et al., 2006; 
Kaymakonova et al., 2008) que en cultivares menos tolerantes, es decir, la acumulación de prolina se correlaciona positivamente con el grado de resistencia al estrés, lo que sugiere una contribución directa a los mecanismos de tolerancia al estrés. Otros informes, por el contrario, mostraron que, bajo condiciones de estrés, los genotipos menos tolerantes tenían una mayor concentración de este osmolito que los cultivares más resistentes (Jiménez-Bremont et al., 2006; Al Hassan et al., 2016; Morosan et al., 2017; Dominguez et al., 2014); por lo tanto, en este caso, la prolina es simplemente un marcador del nivel de estrés que afecta a las plantas, acumulándose en concentraciones más altas en los cultivares más estresados (los más sensibles), pero no está directamente involucrado en los mecanismos de tolerancia. Como lo afirma, Al Hassan (Al Hassan et al., 2016) al comparar dos cultivares comerciales de $P$. vulgaris (Maxidor y "The prince") y una variedad local de judía común español (Judía de Franco) y un cultivar de $P$. coccineus L. (Moonlight) (Al Hassan et al., 2016 y Morosa et al., 2017) y coincide con la versión anterior y afirmando en nuestra investigación aunque con un mayor número de genotipos de diferentes orígenes y un extenso análisis estadístico.

Los resultados expuestos en este trabajo de investigación muestran una fuerte correlación negativa entre los niveles de prolina y las variables de crecimiento, especialmente el peso fresco y el contenido hídrico de la parte aérea de la planta; estos fueron los parámetros más relevantes que permitieron evaluar la inhibición del crecimiento inducida por las condiciones de estrés hídrico y salinidad al que fueron expuestas los cultivares analizados. Por lo tanto existe una asociación inequívoca de un mayor contenido de prolina con una mayor reducción en el crecimiento; es decir, con una mayor sensibilidad al estrés de los cultivares de judía.

Los seis cultivares investigados aquí fueron objeto de un estudio previo sobre la tolerancia a la sal y la sequía en un gran número de cultivares (Arteaga et al., 2020). De los 47 cultivares analizados, BGV004161 y BGV015856 aparecieron como más 
tolerantes al estrés y se caracterizaron por niveles reducidos de prolina bajo estrés, mientras que el cultivar E125 fue uno de los más susceptibles al estrés y mostró un aumento significativo de prolina. bajo estrés hídrico y salino. Los resultados reportados aquí confirmaron que los genotipos más tolerantes identificados en nuestro estudio fueron aquellos que experimentaron el menor aumento en la concentración de prolina en las hojas en respuesta al aumento de la salinidad. La prolina es uno de los solutos compatibles más comunes acumulados por las plantas bajo diferentes tipos de estrés (Szabados \& Savouré, 2010; Grigore et al., 2011). La prolina también tiene una función en la osmoprotección, estabilizando directamente estructuras subcelulares como membranas y proteínas, en la captación de radicales libres o como molécula de señalización en las respuestas al estrés (Hayat et al., 2012; Kavi Kishor et al., 2014; Rana et al., 2017). Se ha reportado acumulación de prolina en judías bajo diferentes condiciones estresantes, desde la presencia de herbicidas (Mackay et al., 1990) o metales pesados (Zengin y Munzuroglu, 2005) hasta sequía (Ashraf e Iram, 2005; Rosales et al., 2012). ; Morosan et al., 2017) y salinidad (Jiménez-Bremont et al., 2006; Nagesh y Devaraj, 2008; Al Hassan et al., 2016). Varios estudios reportaron niveles más altos de prolina en los cultivares más tolerantes al estrés cuando se compararon dos o pocos cultivares (Misra y Gupta, 2005; Cárdenas-Avila et al., 2006; Kaymakonova y Stoeva, 2008; Herrera Flores et al., 2012; Ghanbari et al., 2013), mientras que otros, basados en un mayor número de cultivares, revelaron niveles más altos de prolina en los más susceptibles (Domínguez et al., 2014; Arteaga et al., 2020). En el presente estudio, los niveles de prolina aumentaron con el aumento de la salinidad en todos los cultivares, pero sus valores absolutos fueron menores en los cultivares BGV004161 y BGV015856 más resistentes a la sal. Por el contrario, los contenidos de prolina fueron mayores, y el aumento más pronunciado, en los cuatro cultivares restantes, que en el análisis anterior ya que se clasificaron como más susceptibles al estrés. 
Los azúcares solubles totales (TSS) juegan un papel esencial en el ajuste osmótico bajo estrés en muchas especies de plantas y actúan como moléculas de señalización que regulan la expresión de diferentes genes involucrados en la fotosíntesis, el metabolismo de la sacarosa y la biosíntesis de osmolitos (Rosa et al., 2009). Sin embargo, como los TSS son productos directos de la fotosíntesis y están involucrados en muchos procesos metabólicos, su papel específico en la tolerancia al estrés a veces es difícil de evaluar (Gil et al., 2011). Se informó que la salinidad aumenta los niveles de TSS en las hojas (Abdallah et al., 2016) y en los frutos después de la maduración (Yin et al., 2010) en diferentes especies. Aunque no existe una correlación clara entre el TSS y los tratamientos de sal aplicados (Al Hassan et al., 2016), las concentraciones foliares de algunos azúcares específicos aumentaron considerablemente bajo estrés en diferentes cultivares de frijol, como glucosa e inositol (Bahena-Betancour et al. , 2006) mioinositol (Al Hassan et al., 2016). También se ha observado acumulación de sacarosa y almidón en el pericarpio (Tazuke et al., 2009). En este estudio, se detectó un aumento gradual de TSS en paralelo a la concentración de $\mathrm{NaCl}$ solo en el cultivar susceptible al estrés E125. Para una mejor comprensión de la variación de TSS en este cultivar, se requeriría la separación, identificación y cuantificación de carbohidratos solubles individuales, por ejemplo, mediante análisis de HPLC, para proporcionar una visión más profunda.

Un mecanismo esencial relacionado con las respuestas al estrés salino es la absorción y el transporte de iones. La respuesta principal de los glucófitos en condiciones de alta salinidad del suelo es generalmente bloquear el transporte de iones tóxicos de $\mathrm{Na}^{+}$desde las raíces a los órganos aéreos, a diferencia de las halófitas dicotiledóneas, que generalmente transportan activamente los iones a las hojas y los acumulan en sus vacuolas (Flowers et al., 1986; Flowers y Colmer, 2008).

Se sabe que las plantas del género Phaseolus pueden excluir el sodio de los brotes, incluso en presencia de concentraciones relativamente altas de $\mathrm{NaCl}$ en el 
suelo (Seemann y Critchley, 1985; Bayuelo-Jiménez et al., 2012), y que los mecanismos que restringen el transporte de $\mathrm{Na}^{+}$a la parte aérea de las plantas es más eficiente en los cultivares relativamente más tolerantes (Al Hassan et al., 2016). Este parece ser también el caso del cultivar más resistente al estrés BGV015856 analizado aquí, que mostró los niveles más bajos de $\mathrm{Na}^{+}$bajo estrés salino. La acumulación de sodio generalmente se asocia con una caída en los niveles de $\mathrm{K}$ +, principalmente debido a la competencia de los dos cationes por los mismos sistemas de transporte de membrana (Tester y Davenport, 2003). El potasio se considera el catión "fisiológico", cuya deficiencia tiene efectos adversos sobre la fotosíntesis, la biosíntesis de proteínas y los movimientos impulsados por la turgencia (Gierth y Mäser, 2007). Sin embargo, en todos los cultivares incluidos en el presente estudio, excepto en el E125 el cuál fue más sensible a la sal, el contenido de las hojas de $\mathrm{K}^{+}$ no disminuyó con el aumento de la salinidad externa, incluso aumentó significativamente sobre los niveles de control a altas concentraciones de sal. El mantenimiento de concentraciones de $\mathrm{K}+$ celular relativamente altas en condiciones de estrés salino es un mecanismo fundamental de tolerancia bien conocido (Shabala y Cuin, 2007). El aumento de $\mathrm{K}^{+}$en el tejido foliar es el resultado de la activación del transporte de $\mathrm{K}^{+}$a las hojas a alta salinidad, lo que puede ser considerado como un importante mecanismo de tolerancia en esta especie como en muchas otras (Volkov et al., 2003; Schiop et al., 2015; Kozminska et al., 2018).

La salinidad, como otros tipos de estrés, suele estar asociada con el estrés oxidativo secundario. La MDA, un producto final de la peroxidación lipídica de la membrana, se considera un marcador confiable de estrés oxidativo (Del Rio et al., 2005), ya que uno de los síntomas del daño oxidativo es la degradación de la membrana celular. Sin embargo, no se detectó un aumento significativo de MDA en las plantas tratadas con sal, con la excepción de las plantas del tratamiento $150 \mathrm{mM}$ de $\mathrm{NaCl}$ del cultivar BGV015856, lo que indica que en general no se vieron afectadas 
por el estrés oxidativo inducido por la sal. Estos resultados sugieren que, en las condiciones específicas de nuestros experimentos, los posibles mecanismos de tolerancia basados en la activación de sistemas antioxidantes no son relevantes en los cultivares analizados. Esto explicaría la falta de correlación de los contenidos de TPF y TF con la tolerancia relativa a la sal de los cultivares probados y las concentraciones de sal aplicadas. En otros cultivares de frijol y en diferentes condiciones, sin embargo, existe evidencia de que estos metabolitos secundarios pueden aumentar en respuesta a tratamientos de estrés abiótico (Taibi et al., 2016; Rahma et al., 2019). 
$\underline{\text { Referencias }}$

Conclusiones 
En este estudio se ha comprobado que el estrés hídrico y salino tiene un efecto sobre el crecimiento de $P$. lunatus y $P$. vulgaris, Sin embargo, hay una gran diferencia en los niveles de tolerancia a estos tipos de estrés entre los cultivares analizados. Seguir realizando investigación sobre el estrés abiótico es fundamental ya que permitirá comprender las respuestas de los cultivos y su adaptación e identificación de prácticas agronómicas que permitan aliviar los efectos del estrés salino e hídrico y a su vez preservar la productividad de los cultivos.

Según las investigaciones realizadas durante este proyecto de investigación, se concluye que, durante el crecimiento vegetativo, algunos cultivares de $P$. lunatus podrían tolerar tres semanas de exposición a salinidades superiores con concentraciones superiores a $150 \mathrm{mM} \mathrm{NaCl}$, sin embargo estos estudios deben extenderse a tratamientos salinos más prolongados durante un ciclo de vida completo, dónde se incluya la evaluación de los efectos de la salinidad en las características agronómicas, tales como el rendimiento y la calidad del cultivo en general, esto antes de concluir sobre la tolerancia a la sal de los cultivares de judía de lima. En cualquier caso, los resultados presentados brindan información sobre los mecanismos básicos de contribuyen significativamente a la tolerancia a la salinidad en esta especie, que incluyen el mantenimiento o aumento de las concentraciones de $\mathrm{K}^{+}$y la acumulación de prolina en hojas, como respuesta al tratamiento de estrés salino. Estos mecanismos parecen ser, en parte, innatos, ya que se han medido niveles relativamente más altos de $\mathrm{K}^{+} \mathrm{y}$ prolina en los cultivares más tolerantes también en ausencia de estrés. Por lo tanto, la determinación de las concentraciones foliares de prolina y $\mathrm{K}^{+}$puede presentar una estrategia rápida y sencilla para seleccionar un gran número de cultivares de judía lima con el fin de preseleccionar aquellos genotipos con una mayor probabilidad de ser más tolerantes a salinidad. 
Phaseolus vulgaris no se puede considerar tolerante a la sequía o salinidad. Es incluso más sensible al estrés que muchas otras especies cultivadas. Sin embargo, entre el número extremadamente alto de genotipos disponibles de $P$. vulgaris, algunos mostrarán una resistencia relativamente mayor y podrían usarse como líneas parentales en programas de mejoramiento de judías destinados a mejorar la tolerancia al estrés en este cultivo principal. La identificación de accesiones de judía común en los extremos de variación de susceptibilidad y tolerancia al déficit de agua y salinidad es de gran interés para estudios adicionales sobre los mecanismos fisiológicos de tolerancia a ambos tipos de estrés. Además, el desarrollo de generaciones segregantes después de la hibridación entre ambos tipos de materiales puede conducir a la identificación de regiones genómicas implicadas en la tolerancia a estos estreses. Las concentraciones de prolina en plantas bajo estrés pueden determinar mediante un ensayo espectrofotométrico simple y rápido, que requiere solo pequeñas cantidades de material foliar. Desde un punto de vista práctico, nuestros resultados apoyan el uso de prolina como marcador bioquímico para la selección inicial a gran escala de cultivares de frijol, para excluir los más sensibles, aquellos que acumulan concentraciones más altas de prolina en respuesta al estrés hídrico o salino.

La prolina es un marcador confiable de estrés salino en judía, su contenido de hojas aumenta a niveles más altos en los cultivares más susceptibles al estrés. Uno de los principales mecanismos que confieren una relativa resistencia a la salinidad de la judía común parece ser el transporte activo de potasio a las hojas, manteniendo sus niveles estables o incluso aumentando en respuesta al estrés salino, compensando así en parte los efectos deletéreos de la acumulación tóxica de $\mathrm{Na}^{+}$. Este mecanismo contribuyó a la tolerancia relativamente mayor de dos variedades locales de España en comparación con los otros cultivares analizados en el presente trabajo. Sin embargo, bajo los tratamientos específicos de estrés salino aplicados a 
las plantas, los mecanismos de tolerancia basados en la activación de sistemas antioxidantes no son relevantes ya que no se generó estrés oxidativo secundario. 


\section{Bibliografía}

Abdallah M.M.S., Abdelgawad Z.A., El-Bassiouny H.M.S. (2016). Alleviation of the adverse effects of salinity stress using trehalose in two rice varieties. South African Journal of Botany 103: 275-282

Abdelaal K., Hafez Y., El-Afry M., Tantawy D., Alshaal T. (2018). Effect of some osmoregulators on photosynthesis, lipid peroxidation, antioxidative capacity and productivity of barley (Hordeum vulgare L.) under water deficit stress. Environ. Sci. Pollut. Res., 25 (30), pp. 30199-30211

Abdelhamid M.T., Rady M.M., Osman A.S., Abdalla M.A. (2013). Exogenous application of proline alleviates salt-induced oxidative stress in Phaseolus vulgaris L. plants. J. Hortic. Sci. Biotech, 88, 439-446.

Abebe A.S., Brick M.A. (2003) Traits associated with dry edible bean (Phaseolus vulgaris L.) productivity under diverse soil moisture environments. Euphytica 133:339-347.

Abogadallah G.M. (2010). Antioxidative defense under salt stress. Plant Signal. Behav., 5 (4), pp. 369-374

Adams E., Shin R. (2014) Transport, signaling, and homeostasis of potassium and sodium in plants. J. Integr. Plant Biol., 56, 231-249.

Adger W.N., Barnett J., Brown K., Marshall N., \& O’brien, K. (2013). Cultural dimensions of climate change impacts and adaptation. Nature Climate Change, 3, 112 .

Akbar M., Yabuno T. (1977). Breeding for saline resistant varieties of rice. IV. Inheritance of delayed-type panicle sterility induced by salinity. Jpn. J. Breed. 27: 237-240.

Al Hassan M., Morosan M., López-Gresa M.P., Prohens J., Vicente O., Boscaiu M. (2016). Salinity-induced variation in biochemical markers provides insight into the mechanisms of salt tolerance in common (Phaseolus vulgaris) and runner (P. coccineus) beans. Int. J. Mol. Sci., 17, 1582.

Al Hassan M., Pacurar, A.; Gaspar, A. Vicente, O., Boscaiu, M. (2014).Growth and reproductive success under saline conditions of three Plantago species with different levels of stress tolerance. Not. Bot. Horti Agrobot. 42(1), 180-196.

Alexandratos N., Bruinsma J. (2012). World agriculture towards 2030/2050: the 2012 revision. ESA Working paper No. 12-03. Rome, FAO.

Al-Kaisi M., Elmore R.W., Guzman J.G., Hanna H.M., Hart Ch.E., Helmers M.J., Hodgson E.W., Lenssen A.W., Mallarino A.P., Robertson A.E., Sawyer J.E. (2012). Drought impact on crop production and the soil environment: 2012 experiences from lowa. J. Soil Water Conserv. 68:19-24. 
Allen R.G., Pereira L.S., Raes D., Smith M. (1998). Crop evapotranspiration Guidelines for computing water requirements.

Allen R.G., Yonts C.D., Wright J.L. (2000). Irrigation to maximize bean production and water use efficiency. In: Singh SP (Ed), Bean Research, Production, and Utilization. Proc Idaho Bean Workshop. University of Idaho, Moscow, pp 71-9 Almeida-Costa G., Da Silva Queiroz-Monici K., Pissini Machado Reis S.M., de Oliveira A.C. (2006). Chemical composition, dietary fibre and resistant starch contents of raw and cooked pea, common bean, chickpea and lentil legumes. Elsevier, Food chemistry 94 327-330.

Alsaeedi A., El-Ramady H., Alshaal T., El-Garawany M., Elhawat N., Al-Otaibi A. (2019). Silica nanoparticles boost growth and productivity of cucumber under water deficit and salinity stresses by balancing nutrients uptake. Plant Physiol. Biochem., 139, pp. 1-10

Alsaeedi A.H., El-Ramady H., Alshaal T., El-Garawani M., Elhawat N., Al-Otaibi A. (2018). Exogenous nanosilica improves germination and growth of cucumber by maintaining $\mathrm{K}^{+} / \mathrm{Na}^{+}$ratio under elevated $\mathrm{Na}^{+}$stress. Plant Physiol. Biochem., 125, pp. 164-171

Alsaeedi A.H., El-Ramady H., Alshaal T., El-Garawani M., Elhawat N., Almohsen M. (2017). Engineered silica nanoparticles alleviate the detrimental effects of $\mathrm{Na}^{+}$stress on germination and growth of common bean (Phaseolus vulgaris) Environ. Sci. Pollut. Res., 24 (27), pp. 21917-21928.

Ambavaram M.M., Basu S., Krishnan A., et al. (2014) Coordinated regulation of photosynthesis in rice increases yield and tolerance to environmental stress. Nat Commun. 5:5302. 10.1038/ncomms6302

Andrade E., Ribeiro V., Azvedo C., Chiorato A., Williams T., Carbonell S. (2016) Biochemical indicators of drought tolerance in the common bean (Phaseolus vulgaris L.). Euphytica, 210, 277-289.

Anjum S.A., Xie, X., Wang, L. (2011). Morphological, physiological and biochemical responses of plants to drought stress. - Afr. J. Agr. Res. 6: 2026-2032.

Aparicio-Fernandez X., Yousef G.G., Loarca-Pina G., de Mejia E., Lila M.A. (2005). Characterization of polyphenolics in the seed coat of black Jamapa bean (Phaseolus vulgaris L.). J. Agric. Food Chem. 53(11): 4615-4622.

Arteaga S., Al Hassan M. Wijesinghe C., Yabor L., Llinares J., Boscaiu M., Vicente O. (2018). Screening for Salt Tolerance in Four Local Varieties of Phaseolus Iunatus from Spain. Agriculture, 8, 201.

Arteaga S., Yabor L., Díez M.J., Prohens J., Boscaiu M., Vicente O. (2020). The use of proline in screening for tolerance to drought and salinity in common bean (Phaseolus vulgaris L.) genotypes. Agronomy 10, 817. https: / / doi.org/10.3390/agronomy10060817. 
Arumuganathan K., Earle E.D. (1991) Estimation of nuclear DNA content of plants by flow cytometry. Pl. Molec. Biol. Reporter 9, 221-231.

Arumuganthan K., Earle E.D. (1991) Nuclear DNA content of some important plant species. Plant Mol Biol Rep 9, 208-218.

Ashraf M. (1994). Genetic variation for salinity tolerance ins spring wheat. Hereditas, 120, 99-104.

Ashraf M., Iram A. (2005). Drought stress induced changes in some organic substances in nodules and other plant parts of two potential legumes differing in salt tolerance. Flora, 200, 535-546.

Atchibri ALO-A, Brou K.D., Kouakou T.H., Kouadio Y.J., Gnakri D. (2010) Screening for antidiabetic activity and phytochemical constituents of common bean (Phaseolus vulgaris L.) seeds. J. Med. Plants Res. 4(17), 1757-1761.

Ayala A., Muñoz M.F., Argüelles S. (2014). Lipid peroxidation: production, metabolism, and signaling mechanisms of malondialdehyde and 4-hydroxy2-nonenal Oxid. Med. Cell Longev., p. 360438.

Bacha H., Tekaya M., Drine S., Guasami F., Touil L., Enneb H., Triki T., Cheour F., Ferchichi A. (2017). Impact of salt stress on morpho-physiological and biochemical parameters of Solanum lycopersicum cv. Microtom leaves. S. Afr. J. Bot., 108, 364-369.

Bahena-Betancourt L., Macias-Rodríguez L., Bayuelo-Jiménez J.S. (2006). Contents of carbohydrates in salt-stressed Phaseolus species; Annual Report of the Bean Improvement Cooperative; United States Department of Agriculture: Fort Collins, CO, USA, 2006; pp. 233-234.

Barampama S. and Simard R.E. (1995). Effect of soaking, cooking and fermentation on composition, in vitro starch digestibility and nutritive value of common beans. Plant Foods for Human Nutrition 40, 349-365.

Basu S., Ramegowda V., Kumar A., Pereira A. (2106). Plant adaptation to drought stress. Journal List F1000 Res V.5. PMC4937719.

Bayuelo-Jiménez J.S., Jasso-Plata N., Ochoa I. (2012). Growth and physiological responses of Phaseolus species to salinity stress. Int. J. Agron., 80, 207-222.

Becerra-Velásquez V.L., Gepts P. (1994) RFLP diversity in common bean (Phaseolus vulgaris L.). Genome 37, 256-263.

Bedano J.C., Domínguez A., Arolfo R., Wall L.G. (2016). Efect of good agricultural practices under no-till on litter and soil invertebrates in areas with diferent soil types. Soil and Tillage Research, 158, 100-109.

Belluci E., Bitocchi E., Rau D., Rodriguez M., Biagetti E., Giardini A., Attene G., Nanni L., Papa R. (2013). Genomics of Origin, Domestication and Evolution of Phaseolus vulgaris. Genomics of Plant Genetic Resources. pp 483-507.

Bennett M.D., Leitch I.J. (1995). Nuclear DNA amounts in angiosperms. Ann. Bot. 76, 113-176. 
Bennett M.D.,Leitch I.J. (2010) Angiosperm DNA C-values database (release 7.0, Dec. 2010) http://www.kew.org/cvalues/

Bestelmeyer B.T, Okin G.S., Duniway M.C., et al. (2015). Desertification, land use, and the transformation of global drylands. Front. Ecol. Environ. 13, 28-36.

Betancur D., Chel-Acona L., Guerrero R., Carmelo-Matos G., Ortiz D. (2001). Physicochemical and functional characterization of baby lima bean (Phaseolus lunatus) Starch. Starch 53 (5).

Bhattacharyya R., Das T., Sudhishri S., Dudwal B., Sharma A., Bhatia A., et al. (2015). Conservation agriculture effects on soil organic carbon accumulation and crop productivity under a rice-wheat cropping system in the western Indo-Gangetic Plains. Europ. J. Agron. 70, 11-21.

Bitocchi E, Bellucci E, Giardini A et al (2013) Molecular analysis of the parallel domestication of the common bean in Mesoamerica and the Andes. New Phytol. 197, 300-313

Bitocchi E, Nanni L, Bellucci E et al (2012) Mesoamerican origin of the common bean (Phaseolus vulgaris L.) is revealed by sequence data. Proc. Natl. Acad. Sci. USA 109(14), E788-E796.

Blöschl G., Hall J., Paraijka J., et al. (2017). Changing climate shifts timing of European floods. Science, 357, 588-590.

Bohnert H.J., Nelson D.E, Jensen R.G. (1995). Adaptations to Environmental Stresses. Plant Cell. 7(7), 1099-111. 10.1105/tpc.7.7.1099

Bray E.A. (1997). Plant responses to water deficit. Trends Plant Sci. 2(2):48-54. 10.1016/S1360-1385(97)82562-9

Broughton W.J., Hernandez G., Blair M. et al (2003) Beans (Phaseolus spp.)-model food legumes. Plant Soil 252, 55-128.

Câmara C.R., Urrea C.A. and Schlegel V. (2013). Pinto beans (Phaseolus vulgaris L.) as a functional food: Implications on human health. Agriculture, 3(1), 90-111.

Cameron S.A., Lozier J.D., Strange J.P., Koch J.B., Cordes N., Solter L.F., Griswold T.L. (2001). Patterns of widespread decline in North American bumble bees. Proc. Natl. Acad. Sci. USA 108, 662-667.

Campbell B.M., Thornton P.K. (2014). How Many Farmers in 2030 and How Many Will Adopt Climate Resilient Innovations? CGIAR Research Program on Climate Change, Agriculture and Food Security (CCAFS): Copenhagen, Denmark.

Canet B., Soto-Viquez G. (2017). Caficultura panorama actual en America Latina. IICA. 2017. 155 p.

Cárdenas-Avila M.L., Verde-Star J., Maiti R., Foroughbakhch R., Gámez-González H., Martínez-Lozano S., Núñez-González M., García Díaz G., Hernández-Piñero J., Morales-Vallarta M. (2006). Variability in accumulation of free proline on in vitro calli of four bean (Phaseolus vulgaris L.) cultivars exposed to salinity and induced moisture stress. Phyton, 75, 103-108. 
Caverzan A., Casassola A., Patussi Brammer S. (2016). Reactive oxygen species and antioxidant enzymes involved in plant tolerance to stress. In Abiotic and Biotic Stress in Plants. Recent Advances and Future Perspectives; Shanker, A., Ed.; InTechOpen: London, UK, pp. 463-480

Chacon S., Pickersgill B., Debouck D.G. (2005). Domestication patterns in common bean (Phaseolus vulgaris) and the origin of the Mesoamerican and Andean cultivated races. Theor. Appl. Genet. 110, 432-444.

Checa O., Ceballos H., Blair M. (2006). Generation means analysis of climbing ability in common bean (Phaseolus vulgaris L.). J. Hered. 97, 456-465.

Chen Z., Wang H., Liu X., Zhao X., Lu D., Zhou J., et al. (2017). Changes in soil microbial community and organic carbon fractions under short-term straw return in a rice-wheat cropping system. Soil Till. Res., 165, 121-127.

Cheynier V., Comte G., Davies K.M., Lattanzio V., Martens S. (2013). Plant phenolics: recent advances on their biosynthesis, genetics, and ecophysiology. Plant Physiol. Biochem. 72, 1-20.

Church J., Clark P., Cazenave A., Gregory J., Jevrejeva S., Levermann A., Merrifield G., Milne G., Nerem R., Nunn P., Payne A., Pfeffer W., Stammer D. Unnikrishnan A. (2013). Sea-level rise by 2100 , Science, 342 (6165), p. 1445-1445

Cui Y.F., Meng J., Wang Q.X., Zhang W.M., Cheng X.Y., Chen W.F. (2017). Efects of straw and biochar addition on soil nitrogen, carbon, and super rice yield in cold waterlogged paddy soils of North China. J. Integr. Agriculture, 16, 10641074.

Cuny M.A., La Forgia D., Desurmont G.A., Glauser G., Benrey B. (2019). Role of cyanogenic glycosides in the seeds of wild lima bean, Phaseolus lunatus: defense, plant nutrition or both? Planta, 250, 1281-1292.

Dai A. (2012) Increasing drought under global warming in observations and models. Nat. Clim. Chang. 3, 52-8. 10.1038/nclimate1633.

Dasgupta S., Hossain M.M., Huq M., Wheeler D. (2015). Climate change and soil salinity: The case of coastal Bangladesh. Ambio 44:815-826.

De Pascale S. Barbieri G., Ruggiero C. (1997). Effects of water salinity on plant growth and water relations in snap bean (Phaseolus vulgaris L.). Acta Hortic., 449, 649-656.

Debouck D.G. (2008) Notes sur Les Différents Taxons de Phaseolus à Partir des Herbiers. Cahiers de Phaséologie-Section Paniculati; International Center for Tropical Agriculture (CIAT): Cali, Colombia, p. Proc. Natl. Acad. Sci. USA 233. Available online: http://www.ciat.cgiar.org/urg (accessed on 11 February 2019).

Debouck D.G., Toro O., Paredes O.M. et al (1993) Genetic diversity and ecological distribution of Phaseolus vulgaris in northwestern South America. Econ. Bot. 47:408-423 
Del Rio D., Stewart A.J., Pellegrini N. (2005). A review of recent studies on malondialdehyde as toxic molecule and biological marker of oxidative stress. Nutr. Metab. Cardiovasc. Dis. 15, 316-328.

Del Río L.A., Palma J.M., Sandalio L.M., Corpas F.J., Pastori G.M., Bueno P., LópezHuertas E. (1996). Peroxisomes as a source of superoxide and hydrogen peroxide in stressed plants. Biochem. Soc. Trans. 24, 434-438.

Delgado-Salinas A.O., Bibler R. Lavin, M. (2006). Phylogeny of the genus Phaseolus (Leguminosae): A recent diversification in an ancient landscape. Syst. Bot. 31:779-791.

Deshpande S.S., Sathe S.K., Salunkhe D.K., Cornforth D.P. (1982). Effects of dehulling on phyticacid, polyphenols, and enzyme inhibitors of dry beans (Phaseolus vulgaris L.). J. Food Sci. 47(6), 1846-1850.

Desiderio F., Bitocchi E., Bellucci E. et al (2013) Chloroplast microsatellite diversity in Phaseolus vulgaris. Front Plant Sci. 3, 312.

Di Ferdinando M., Brunetti C., Fini A., Tattini M. (2012). Flavonoids as Antioxidants in Plants under Abiotic Stresses. In: Ahmad, P., Prasad, M.N.V. (Eds.), Abiotic Stress Responses in Plants: Metabolism, Productivity and Sustainability. Springer, New York pp, pp. 159-179.

Diamond J.M. (2005). Collapse: how societies choose to fail or succeed. New York, NY: Viking Press.

Díaz-Batalla L., Widholm J.M., Fahey G.C., Castaño-Tostado E., Paredes-López O. (2006) Chemical components with health implications in wild and cultivated Mexican common bean seeds (Phaseolus vulgaris L.). J. Agric. Food Chem. 54(6), 2045-2052.

Domínguez A., Yunel-Pérez Y., Alemán S., Sosa M., Fuentes L., Darias R., Demey J., Rea R., Sosa D. (2014). Respuesta de cultivares de Phaseolus vulgaris L. al estrés por sequía. Biot. Veg. 14, 29-36.

Donat M.G., Lowry A.L., Alexander L.V., O'Gorman P.A., Maher N. (2016). More extreme precipitation in the world's dry and wet regions. Nature Climate Change, 6, 508-513

Elhawat N., Alshaal T., Hamad E., El-Nahrawy E., Omara A.E.D, El-Nahrawy S., T. Elsakhawy, A. Ghazi, A. Abdalla, É. Domokos-Szabolcsy, El-Ramady, H. (2018). Nanoparticle associated phytotoxicity and abiotic stress under agroecosystems. In: M. Faisal, et al. (Eds.), Phytotoxicity of Nanoparticles, Springer International Publishing AG, pp. 241268, 10.1007/978-3-319-76708-6_10.

El-Ramady H., Alshaal T., Bakr N., Elbana T., Mohamed E., Belal A.A. (2019). Soils of Egypt. World Soils Book Series (first ed.), Springer International Publishing AG (2019), 10.1007/978-3-319-95516-2.

El-Ramady H., Alshaal, Elhawat N., Ghazi A., Elsakhawy T., Omara A.E.D., El-Nahrawy S., Elmahrouk M., Abdalla N., Domokos-Szabolcsy É., Schnug E. (2018a). 
Plant nutrients and their roles under saline soil conditions. M. Hasanuzzaman, et al. (Eds.), Plant Nutrients and Abiotic Stress Tolerance, Springer Nature Singapore Pte Ltd., pp. 297-324, 10.1007/978981-10-9044-8_13

El-Zawily A., Meleha M., El-Sawy M., El-Attar E., Bayoumi Y., Alshaal T. (2019). Application of magnetic field improves growth, yield and fruit quality of tomato irrigated alternatively by fresh and agricultural drainage water. Ecotoxicol. Environ. Saf., 181 , pp. 248-254

Escribano M., De Ron A., Amurrio, J. (1994). Diversity in agronomical traits in common bean populaltions from northwestern Spain. Euphytica, 76, 1-6.

Escribano M., Santalla M., Casquero, P., De Ron A. (1998). Patterns of genetic diversity in landraces of common bean (Phaseolus vulgaris L.) from Galicia. Plant Breed. 117, 49-56.

Esfandiari E., Shekari F., Shekari F., Esfandiari M. (2007). The effect of salt stress on antioxidant enzymes activity and lipid peroxidation on the wheat seedling. Notulae Botanicae Horti Agrobotanici Cluj-Napoca 35, 48-56.

FAO \& ITPS. (2015). Status of the World's Soil Resources (SWSR) - Main Report Food and Agriculture Organization of the United Nations and Intergovernmental Technical Panel on Soils, Rome, Italy.

FAO (2015). The State of Food and Agriculture 2015 in Brief (Sofa); Food and Agriculture Organization of the United Nations: Rome, Italy.

Farooq M., Wahid A., Kobayashi N., Fujita D., Basra S.M.A. (2009). Plant drought stress: effects, mechanisms and management. Agron. Sustain. Dev. 29: 185212.

Fini, A.; Brunetti, C.; Di Ferdinando, M.; Ferrini, F.; Tattini, M. (2011). Stress-induced flavonoid biosynthesis and the antioxidant machinery of plants. Plant Signal. Behav., 6, 709-711

Fishman R. (2018). Groundwater depletion limits the scope for adaptation to increased rainfall variability in India. Climatic Change, 147, 195-209.

Fiwa L., Vanuytrecht E., Wiyo K.A., Raes D. (2014). Effect of rainfall variability on the length of the crop growing period over the past three decades in central Malawi. Climate Res., 62, 45-58.

Flowers T.J., Colmer T.D. (2008). Salinity tolerance in halophytes, New Phytol. 179:945-963.

Flowers T.J., Hajibagheri M.A., Clipson N.J.W. (1986). Halophytes. Quart. Rev. Biol. 61, 313-335.

Frahm M.A., Rosas J.C., Mayek-Perez N., Lopez-Salinas E., Acosta-Gallegos JA., Kelly J.D. (2004) Breeding beans for resistance to terminal drought in the lowland tropics. Euphytica 13, 223-232.

Freyre R., Ríos R., Guzmán L. et al (1996) Ecogeographic distribution of Phaseolus spp. (Fabaceae) in Bolivia. Econ. Bot. 50,195-215. 
Fueyo M.A. (2004). Producción de judías de calidad. SERIDA, KRK Ediciones, Cooperativa de Agricultures, Consumidores y Usuarios del Concejo de Gijón, Oviedo.

Gaff D.F. (1971). Desiccation-tolerant flowering plants in southern Africa. Science.174(4013):1033-4. 10.1126/science.174.4013.1033.

Gaff D.F. (1987). Desiccation tolerant plants in South America. Oecologia. 74(1):1336. $10.1007 /$ BF00377357

Gama P.B.S., Inanaga S., Tanaka K., Nakazawa R. (2007). Physiological response of common bean. (Phaseolus vulgaris L.) seedlings to salinity stress. Afr. J. Biotechnol., 6, 79-88.

Gao W., Bai S., Li Q., Gao C., Liu G., Li G., Tan F. (2013). Overexpression of TaLEA gene from Tamarix androssowii improves salt and drought tolerance in transgenic poplar (Populus simonii $x$ P. nigra) PloS One, 8 (6) (2013), Article e67462, 10.1371 /journal.pone.0067462.

Gepts P., Bliss F.A. (1985). F1 hybrid weakness in the common bean: differential geographic origin suggests two gene pools in cultivated bean germplasm. J. Hered. 76, 447-450.

Gepts P., Debouck D.G. (1991). Origen. Domestication and evolution of the common bean (Phaseolus vulgaris L.). In: Schoonhoven, A. Van and Voyset, O. (Eds.). Common bean research for crop improvement. CAB. International. 7-53 p.

Gepts P., Osborn T.C., Rashka K. et al (1986) Phaseolin-protein variability in wild forms and landraces of the common bean (Phaseolus vulgaris): evidence for multiple centers of domestication. Econ Bot 40, 451-468.

Ghanbari A.A., Mousavi S.H., Mousapou-Gorji A., Rao I. (2013). Effects of water stress on leaves and seeds of bean (Phaseolus vulgaris L.). Turk. J. Field Crops 18, 73-77.

Gierth M., Mäser P. (2007). Potassium transporters in plants- Involvement in K+ acquisition, redistribution and homeostasis. FEBS Lett., 581, 2348-2356.

Gil J., De Ron A. (1992). Variation in Phaseolus vulgaris in the Northwest of the Iberian Peninsula. Plant Breed., 109, 313-319

Gil R., Bautista I., Boscaiu M., Lidón A., Wankhade S., Sánchez H., Llinares J., Vicente O. (2014). Responses of five Mediterranean halophytes to seasonal changes in environmental conditions. AoB Plants, 6, plu049.

Gil R., Boscaiu M.T., Lull C., Bautista I., Lidón A.L., Vicente O. (2013). Are soluble carbohydrates ecologically relevant for salt tolerance in halophytes? Funct. Plant Biol. 40, 805-818.doi:10.1071 /FP12359.

Gleadow R.M., Woodrow I.E. (2002). Constraints on effectiveness of cyanogenic glycosides in herbivore defense. J. Chem. Ecol., 28, 1301-1313.

Glémin S., Bataillon T. (2009) A comparative view of the evolution of grasses under domestication. New Phytol. 183, 273-290. 
Glenn E.P. (1987). Relationship between cation accumulation and water content of salt tolerant grasses and a sedge. Plant Cell Environ., 10, 205-212.

Glenn E.P., Brown J.J., Blumwald E. (1999). Salt tolerance and crop potential of halophytes. Crit. Rev. Plant Sci., 18, 227-255.

Gornall J., Betts R., Burke E., Clark R., Camp J., Willett K., Wiltshire A. (2010). Implications of climate change for agricultural productivity in the early twentyfirst century. Phil. Trans. Royal Soc. B 365, 2973-2989.

Grigore M.N., Boscaiu M., Vicente O. (2011). Assessment of the relevance of osmolyte biosynthesis for salt tolerance of halophytes under natural conditions. Eur. J. Plant Sci. Biotechnol. 5, 12-19.

Guan Y.S., Serraj R., Liu S.H. et al. (2010). Simultaneously improving yield under drought stress and non-stress conditions: a case study of rice (Oryza sativa L.). J. Exp. Bot., 61(15), 4145-56. 10.1093/jxb/erq212

Gupta R., Somanathan, E., Dey S. (2017). Global warming and local air pollution have reduced wheat yields in India. Climatic Change, 140, 593-604.

Gürel F., Öztürk Z.N., Uçarlı C., Rosellini D. (2016). Barley genes as tools to confer abiotic stress tolerance in crops. Front. Plant Sci., 7, 1137.

Hannachi, M.C. Van Labeke. (2018). Salt stress affects germination, seedling growth and physiological responses differentially in eggplant cultivars (Solanum melongena L.) Sci. Hortic., 228, 56-65.

Hare P.D., Cress W.A. (1997). Metabolic implications of stress induced proline accumulation in plants. Plant Growth Regul. 21, 79-102.

Hasanuzzaman M., Alam M.M., Rahman A., Hasanuzzaman M., Nahar K., Fujita M. (2014). Exogenous proline and glycine betaine mediated upregulation of antioxidant defense and glyoxalase systems provides better protection against salt-induced oxidative stress in two rice (Oryza sativa L.) varieties. BioMed Res. Int., 1-17.

Hayat I., Ahmad A., Masud T., Ahmed A., Bashir S. (2014). Nutritional and health perspectives of beans (Phaseolus vulgaris L.): an overview. Crit. Rev. Food Sci. Nutr., 54(5), 580-592.

Hayat S., Hayat Q., Alyemeni M.N., Wani A.S., Pichtel J., Ahmad, A. (2012). Role of proline under changing environments: A review. Plant Signal. Behav., 7, 14561466.

He Y., He X., Xu M., Zhang W., Yang X.,Huang S. (2018). Long-term fertilization increases soil organic carbon and alters its chemical composition in three wheat-maize cropping sites across central and south China. Soil Till. Res. 177 , 79-87.

Herrera-Flores T.S., Ortíz-Cereceres J., Delgado-Alvarado A., Acosta-Galleros J.A. (2012). Growth and, proline and carbohydrate content of bean seedlings subjected to drought stress. Rev. Mexicana Cienc. Agric., 3, 713-725. 
Hosfield G., Uebersax M., Isleb T. (1984). Seasonal and genotypic effects on yield and physico-chemical seed characteristics related to food quality $\mathrm{n}$ dry, edible beans. J. Am. Soc. Hort. Sci., 109, 182-189.

Huang J, Yu H, Guan X, et al. 2015. Accelerated dryland expansion under climate change. Nat Clim Change 6: 166-71.

Gayathri-Ilangumaran J.R., Lamont-Donald L. S. (2018). The role of the phytomicrobiome in maintaining biofuel crop production in a changing climate. Book Editor(s):Prem Lal Kashyap, Alok Kumar Srivastava, Shree Prakash Tiwari, Sudheer Kumar.

IPCC (Intergovernmental Panel on Climate Change). (2014). Summary for policymakers. In: Climate change 2014: impacts, adaptation, and vulnerability. Part A: global and sectoral aspects. Contribution of Working Group II to the Fifth Assessment Report of the Intergovernmental Panel on Climate Change. Geneva, Switzerland: IPCC4

Jacobi B. (1964). Function of bean roots and stems in sodium retention. Plant Physiol., 39, 445-449.

Jaleel C.A., Gopi R., Manivannan P., Panneerselvam R. (2007). Antioxidative potentials as a protective mechanism in Catharanthus roseus (L.) G. Don. plants under salinity stress. Turk. J. Bot.31, 245-251

Jaleel C.A., Gopi R., Sankar B., Gomathinayagam M., Panneerselvam R., (2008). Differential responses in water use efficiency in two varieties of Catharanthus roseus under drought stress. -Comp. Rend. Biol. 331, 42-47.

James L.G. (1988). Principles of Farm Irrigation System Design. John Wiley \& Sons, Inc., New York.

Jeong J.S., Kim Y.S., Baek K.H., et al. (2010). Root-specific expression of OsNAC10 improves drought tolerance and grain yield in rice under field drought conditions. Plant Physiol. 153(1):185-97. Doi: 10.1104/pp.110.154773.

Jeong J.S., Kim Y.S., Redillas M.C., et al. (2013). OsNAC5 overexpression enlarges root diameter in rice plants leading to enhanced drought tolerance and increased grain yield in the field. Plant Biotechnol. J. 11(1), 101-14. Doi: $10.1111 / \mathrm{pbi} .12011$

Jiménez-Bremont J.F., Becerra-Flora A., Hernández-Lucero E., Rodríguez-Kessler M., Acosta-Gallegos J.A., Ramírez-Pimentel J.G. (2006). Proline accumulation in two bean cultivars under salt stress and the effect of polyamines and ornithine. Biol. Plant. 50, 763-766.

Jones D.A. (1998). Why are so many food plants cyanogenic? Phytochemistry 47, 115-162.

Jones M.M., Turner N.C., Osmond C.B. (1981). Mechanisms of drought resistance. The physiology and biochemistry of drought resistance in plants. Eds LG Paleg and D Aspinall. 1:15-37. Academic Press, New York. 
Jongdee B., Fukai S., Cooper M. (2002). Leaf water potential and osmotic adjustment as physiological traits to improve drought tolerance in rice. Field Crops Res. 76(2-3):153-63. Doi. 10.1016/S0378-4290(02)00036-9.

Kalra N., Kuma, M. (2018). Simulating the Impact of Climate Change and its Variability on Agriculture. In: Climate Change and Agriculture in India: Impact and Adaptation pp 21-28.

Kami J., Becerra-Velásquez V., Debouck D.G. et al (1995) Identification of presumed ancestral DNA sequences of phaseolin in Phaseolus vulgaris. Proc. Natl. Acad. Sci. USA 92, 1101-1104.

Kaplan L. (1981). What is the origin of common bean? Econ. Bot. 35, 240-254.

Kapuya J.A., Barendse G.W.M., Linskens H.F. (1985). Water stress tolerance and proline accumulation in Phaseolus vulgaris L. Acta Bot. Neerl., 34, 293-300.

Karamesouti M., Detsis V., Kounalaki A., et al. (2015). Land-use and land degradation processes affecting soil resources: evidence from a traditional Mediterranean cropland (Greece). Catena 132, 45-55.

Karimi V., Karami E., Keshavarz M. (2018). Climate change and agriculture: Impacts and adaptive responses in Iran. Journal of Integrative Agriculture, 17(1): 1-15

Kaur G., Asthir B. (2017). Molecular responses to drought stress in plants. Biol. Plant. 61 (2), 201-209. DOI: 10.1007/s10535-016-0700-9.

Kavi-Kishor P., Sreenivasulu N. (2014). Is proline accumulation per se correlated with stress tolerance or is proline homeostasis a more critical issue? Plant Cell Environ. 37, 300-311.

Kaymakonova M., Stoeva N. (2008) Physiological responses of bean plants (Phaseolus vulgaris L.) to salt stress. Gen. Appl. Plant Physiol., 34, 177-188.

Kerr J.T., Galpern P., Packer L., Potts S.G., Roberts S.M., Rasmont P. et al. (2015). Climate change impacts on bumblebee converge across continents. Science 349, 177-180.

Khan K., Agarwal P., Shanware A., Sane V.A. (2015). Heterologous expression of two Jatropha aquaporins imparts drought and salt tolerance and improves seed viability in transgenic Arabidopsis thaliana. PLoS One 10(6):e0128866. doi:10.1371/journal.pone.0128866

Koenig R., Gepts P. (1989) Allozyme diversity in wild Phaseolus vulgaris: further evidence for two major centers of diversity. Theor. Appl. Genet. 78, 809-817.

Kozminska A., Wiszniewska A., Hanus-Fajerska E., Boscaiu M., Al Hassan M., Halecki W., Vicente O. (2019). Identification of salt and drought biochemical stress markers in several Silene vulgaris populations. Sustainability, 11, 800.

Kramer D., Läuchli A., Yeo A.R., Gullasch J. (1977). Transfer cells in roots of Phaseolus coccineus: Ultrastructure and possible function in exclusion of sodium from the shoot. Ann. Bot., 41, 1031-1040.

Kusvuran S., Dasgan H.Y. (2017). Effects of drought stress on physiological and biochemical changes in Phaseolus vulgaris L. Legume Res., 40, 55-62. 
Kutos T., Golob T., Kac M., Plestenjak, A. (2003). Dietary fibre content of dry and processed beans. Elsevier 80 (2) pp 231-235. https://doi.org/10.1016/S0308-8146(02)00258-3

Kwak M., Gepts P. (2009). Structure of genetic diversity in the two major gene pools of common bean (Phaseolus vulgaris L., Fabaceae). Theor. Appl. Genet. 118 , 979-992.

La Calle A. (2007). Sequía y adaptación de la Directiva marco del agua. En La Sequía en España. Directrices para Minimizar su Impacto. Madrid: Ministerio de Medio Ambiente.

Lal R., Delgado J.A., Gulliford J., Nielsen D., Rice Ch.W., Pelt R.S.V. (2012). Adapting agriculture to drought and extreme events. J. Soil Water Conserv. 67, 162-166.

Lehmann J., Coumou D., Frieler K. (2015). Increased record-breaking precipitation events under global warming. Climate Change, 132(4), 501-515.

Lemma M., Alemie A., Habtu, S., Lemma, C. (2016). Analyzing the impacts of on onset, length of growing period and dry spell length on chickpea production in Adaa District (East Showa Zone) of Ethiopia. J. Earth Sci. Clim. Change, 7, 349

Levitt J. (1980). Responses of plants to environmental stresses. Volume II. Water, radiation, salt, and other stresses, Academic Press.

Lewis S.L., Maslin, M.A. (2015). Defining the Anthropocene. Nature 519: 171-180.

Lobell D.B., Hammer G.L., Chenu K., Zheng B., McLean G., Chapman S.C. (2015). The shifting infuence of drought and heat stress for crops in northeast Australia. Global Change Biol., 21, 4115-4127.

Lopez F.B., Johansen C., Chauhan Y. S. (1996a). Effects of timing of drought stress on phenology, yield and yield components of short-duration pigeonpea. J. Agron. Crop Sci. 177, 31 1-320. Wiley Online Library Web of Science ${ }^{\circledR}$ Google Scholar

Lopez F.B., Chauhan Y.S., Johansen C. (1996b). Effects of timing of drought stress on abscission and dry matter partitioning of short-duration pigeonpea. $J$. Agron. Crop Sci. 177, 327- 338.

Maas, E.V.; Hoffman, G.J. Crop salt tolerance-current assessment. J. Irrig. Drain. Eng. 1977, 103, 115-134.

Mackay C.E., Hall C., Hofstra G., Fletcher R.A. (1990). Uniconazole-induced changes in abscisic acid, total amino acids, and proline in Phaseolus vulgaris. Pestic. Biochem. Physiol. 37, 74-82.

Mahajan S., Tuteja N. (2005). Cold, salinity and drought stresses: an overview. Arch. Biochem. Biophys, 444, 139-158.

Marshall H.D., Newton C., Ritland K. (2002). Chloroplast phylogeography and evolution of highly polymorphic microsatellites in lodgepolepine (Pinus contorta). Theor. Appl. Genet. 104, 367-378. 
Martínez-Nieto M., Estrelles E., Prieto-Mossi J., Roselló J., Soriano P. (2020). Resilience Capacity Assesment of the Traditional Lima Bean (Phaseolus lunatus L.) Landraces Facing Climate Change. Agronomy 10 (6), 758.

Matiu M., Ankerst D.P., Menzel A. (2017). Interactions between temperature and drought in global and regional crop yield variability during 1961-2014. PLoS ONE, 12, e0178339.

McNeil S.D., Nuccio M.L., Hanson A.D. (1999). Betaines and related osmoprotectants. Targets for metabolic engineering of stress resistance. Plant Physiol., 120, 945-949.

Miettinen J., Stibig H-J., Achard F. (2014). Remote sensing of forest degradation in Southeast Asia - aiming for a regional view through 5-30 m satellite data. Global Ecol. Conserv. ,2, 24-36.

Mimms O.L., Zaumeyer W.J. (1947) Growing dry bean in the Western States. Farmers' Bulletin No. 1996. U.S. Dept. Agric., Washington D.C.

Misra N., Gupta A.K. (2005). Effect of salt stress on proline metabolism in two high yielding genotypes of green gram. Plant Sci., 169, 331-339.

Misra N., Gupta A.K. (2005). Effect of salt stress on proline metabolism in two high yielding genotypes of green gram. Plant Sci., 169, 331-339.

Mittler R (2002) Oxidative stress, antioxidants and stress tolerance. Trends Plant Sci., 7:405-410.

Morgan J.M. (1984). Osmoregulation and Water Stress in Higher Plants. Annu. Rev. Plant Physiol., 35:299-319. Doi: 10.1146/annurev.pp.35.060184.001503.

Morosan M., Al Hassan M., Naranjo M., Lopez-Gresa M.P., Vicente O. (2017). Comparative analysis of drought responses in Phaseolus vulgaris (common bean) and $P$. coccineus (runner bean) cultivar. EuroBiotech J., 1, 247-252.

Morosan M., Al Hassan M., Naranjo M., Lopez-Gresa M.P., Vicente O. (2017). Comparative analysis of drought responses in Phaseolus vulgaris (common bean) and $P$. coccineus (runner bean) cultivar. EuroBiotech J., 1, 247-252.

Morton, J.F. (2007). The impact of climate change on smallholder and subsistence agriculture. Proc. Natl. Acad. Sci. USA , 104, 19680-19685.

Munns R. (2002). Comparative physiology of salt and water stress. Plant Cell Environ., 25: 239-250.

Munns R., Tester M. (2008). Mechanisms of salinity tolerance. Annu. Rev. Plant Biol., 59, 651-681.

Muñoz-Velazquez E., Rubio-Hernández D., Bernal-Lugo I., Garza-García R., JacintoHernández C. (2009). Characterization of native bean genotypes from the state of Hidalgo, based on its grain quality. Agric. Téc. Mex 35 (4).

Nadeem M., Li J., Yahya M., Sher A., Ma C., Wang X., Qiu L. (2019). Research progress and perspective on drought stress in legumes: A review. Int. J. Mol. Sci., 20(1), 2541 ; https://doi.org/10.3390/ijms20102541. 
Naeem M., Ansari A.A., Gill S.S., Aftab T., Idrees M., Ali A., Khan M.M.A. (2017). Regulatory role of mineral nutrients in nurturing of medicinal legumes under salt stress. In: Naeem $M$ et al. (eds) Essential plant nutrients. Springer International Publishing, Cham. https://doi. org/10.1007/978-3-31958841-4_12

Nagesh B., Devaraj V. (2008). High temperature and salt stress response in French bean (Phaseolus vulgaris). Austr. J. Crop Sci., 2, 40-42.

Nanni L, Bitocchi E, Bellucci E et al (2011) Nucleotide diversity of a genomic sequence similar to SHATTERPROOF (PVSHP1) in domesticated and wild common bean (Phaseolus vulgaris L.). Theor. Appl. Genet. 123, 1341-1357.

Nienhuis J., Singh S. (1986). Combining ability analyses and relationships among yield, yield components and architectural traits in dry bean. Crop Sci., 26, 21 27.

Nyau V. (2014). Nutraceutical perspectives and utilization of common beans (Phaseolus vulgaris L.): A review. Afr. J. Food Agric. Nutr. Dev., 14(7), 94839496.

Ogden L., Heynen N., Oslender U., West P., Kassam K.A., Robbins P. (2013). Global assamblages, resilience, and Earth stewardship in the Antropocene. Frontiers in Ecology and the Environment, 11 (7), 341-347

Olcina-Cantos J. (2001). Causas de las sequías en España. Aspectos climáticos y geográficos de un fenómeno natural. En: Gil Olcina, Antonio y Morales Gil, Alfredo (Eds.). Causas y consecuencias de las sequías en España. Instituto Universitario de Geografía de la Universidad de Alicante y Caja de Ahorros del Mediterráneo, Alicante, 49-109.

Olmedilla-Alonso B., Farré-Rovir R., Asensio Vegas C., Martin-Pedrosa M. (2010). Papel de las leguminosas en la alimentación actual. Elsevier 14 (2). Pp 72-76.

Onyilagha J.C. Islam S. (2009). Flavonoids and other polyphenols of the cultivated species of the genus Phaseolus. Int. J. Agric. Biol. 11, 231- 234.

Oomah B.D., Corbé A., Balasubramanian P. (2010) Antioxidant and anti-inflammatory activities of bean (Phaseolus vulgaris L.) hulls. J. Agric. Food Chem. 58(14), 8225-8230.

Osborne T.M., Wheeler T.R. (2013). Evidence for a climate signal in trends of global crop yield variability over the past 50 years. Env. Res. Lett., 8, 024001.

Oya T., Nepomuceno A.L., Neumaier N., Farias J.R.B., Tobita S., Ito O. (2004). Drought tolerance characteristics of Brazilian soybean cultivars: evaluation and characterization of drought tolerance of various Brazilian soybean cultivars in the field. Plant Prod. Sci. 7, 129- 137.

Pantuwan G., Fukai S., Cooper M., et al. (2002). Yield response of rice (Oryza sativa L.) genotypes to drought under rainfed lowland: 3. Plant factors contributing to drought resistance. Field Crops Res.,73(2-3), 181-200. Doi. 10.1016/S0378-4290(01)00194-0 
Papa R., Gepts P. (2003). Asymmetry of gene flow and differential geographical structure of molecular diversity in wild and domesticated common bean (Phaseolus vulgaris L.) from Mesoamerica. Theor. Appl. Genet. 106., 239-250.

Paredes M., Becerra V., Tay J. (2009). Inorganic nutritional composition of common bean (Phaseolus vulgaris L. genotypes Race Chile. Chilean J. Agric. Res., 69(4), 486-495

Park S.C., Kim T.W., Kim S-K. (2000). Identification of brassinosteroids with 24Rmethyl in immature seeds of Phaseolus vulgaris. Bull. Korean Chem. Soc., $21(12), 1274-1276$.

Parvaiz A.S., Satyawati S. (2008). Salt stress and phyto-biochemical responses of plants-A review. Plant Soil Environ., 54, 89-99.

Perez-Vega E., Campa A., De la Rosa L,. Giraldez R., Ferreira J. (2009). Genetic diversity in a core collection established from the main bean genebank in Spain. Crop Sci., 49, 1377-1386.

Plazas M., Nguyen H., González-Orenga S., Fita A., Vicente O., Prohens J., Boscaiu M. (2019). Comparative analysis of the responses to water stress in eggplant (Solanum melongena) cultivars. Plant Physiol. Biochem., 143, 72-82.

Porembski S. (2000). Granitic and gneissic outcrops (inselbergs) as centers of diversity for desiccation-tolerant vascular plants. Plant Ecol., 151(1), 19-28. 10.1023/A:1026565817218

Porter, J.R., Xie L.., Challinor A.J., Cochrane K.., Howden S.M., Iqbal M.M., Lobell D.B., and Travasso M.I. (2014). Food security and food production systems. In: Climate Change 2014: Impacts, Adaptation, and Vulnerability. Working Group II. Contribution to the IPCC 5th Assesment Report, Genova, Switzerland.

Praba M.L., Cairns J.E., Babu R.C., Lafitte H.R. (2009). Identification of physiological traits underlying cultivar differences in drought tolerance in rice and wheat. J. Agron. Crop Sci. 195, 30-46, 2009.

Prakash M., Ramachandran K. (2000). Effects of chemical ameliorants in brinjal (Solanum melongena L.) under moisture stress conditions. J. Agron. Crop Sci., 185, 237-239.

Prasad P.V.V., Pisipati S.R., Momčilović I., Ristic Z. (2011). Independent and combined effects of high temperature and drought stress during grain filling on plant yield and chloroplast EF-Tu expression in spring wheat. J. Agron. Crop Sci. 197, 430-441.

Prolla I.R. D., Garcia-Barbosa R., Lima-Veeck A. P., Rossini-August P., Picolli-daSilva L., Dalfollo-Ribeiro N., Emanuelli T. (2010). Cultivar, harvest year and storage conditions affecting nutritional quality of common beans (Phaseolus vulgaris L.). Ciênc. Tecnol. Aliment. 30: 96-102

Provan J., Soranzo N., Wilson N.J. et al (1999) A low mutation rate for chloroplast microsatellites. Genetics 153:943-947. 
Ramegowda V, Basu S, Krishnan A, et al. (2014). Rice GROWTH UNDER DROUGHT KINASE is required for drought tolerance and grain yield under normal and drought stress conditions. Plant Physiol.,166(3):1634-45. $10.1104 /$ pp. 114.248203.

Ramírez-Vallejo P., Kelly J. (1998) Traits related to drought resistance in common bean. Euphytica 99:127-136.

Rana J.H., Patel U.R., Patel S.J., Lambole V., Shah D.P. (2016). Pharmacological activities of Phaseolus vulgaris: A review. Pharma Sci. Mon., 7(2), 107-115.

Rana V., Ram S., Nehra K. (2017). Proline biosynthesis and its role in abiotic stress. Int. J. Agric. Res. Innov. Technol. 6.

Ray D.K., Gerber J.S., Mac-Donald G.K.,West P.C.(2015). Climate variation explains a third of global crop yield variability. Nat. Commun., 6, 5989.

Redillas M.C., Jeong J.S., Kim Y.S., et al. (2012). The overexpression of OsNAC9 alters the root architecture of rice plants enhancing drought resistance and grain yield under field conditions. Plant Biotechnol J., 10(7), 792-805. $10.1111 /$ j.1467-7652.2012.00697.x

Reed M.S., Stringer L.C. (2016). Land degradation, desertification and climate change: anticipating, assessing and adapting to future change. New York, NY: Routledge

Reynoso C., Ramos G. Loarca P. (2006). Bioactive components in common beans (Phaseolus vulgaris L.), In: Advances in Agricultural and Food Biotechnology, R.G. Guevara González and I. Torres-Pacheco, Editors. Research Signpost: Trivandrum, Kerala, India, 217-236.

Rhodes D., Hanson A.D. (1993). Quaternary ammonium and tertiary sulfonium compounds in higher plants. Annu. Rev. Plant Physiol. Plant Mol. Biol., 44, 357-384.

Rico A.M. (2004). Sequías y abastecimientos de agua potable en España. Boletín de la Asociación de Geógrafos Españoles, 37, 137-181.

Rodiño P., Santalla M., De Ron A., Singh S. (2003). A core collection of common bean from the Iberian peninsula. Euphytica, 131, 165-175.

Rodriguez-Navarro A., Rubio F. (2006). High-affinity potassium and sodium transport systems in plants. J. Exp. Bot., 57, 1149-1160.

Rosa M., Prado C., Podazza G., Interdonato R.; González J.A., Hilal M., Prado F.E. (2009). Soluble sugars-Metabolism, sensing and abiotic stress. A complex network in the life of plants. Plant Signal. Behav., 4(5), 388-393; DOI: 10.4161 /psb.4.5.8294.

Rosadi R.A.B., Afandi M. S., Senge M., Ito K., Adomako J. T.( 2005). Critical water content and water stress coefficient of soybean (Glycine max [L.] Merr.) under deficit irrigation. Paddy Water Environ., 3, 219- 223.

Rosales M.A., Ocampo O., Rodríguez-Valentín R., Olvera-Carrillo Y., Acosta-Gallegos J., Covarrubias A.A. (2012). Physiological analysis of common bean (Phaseolus 
vulgaris L.) cultivars uncovers characteristics related to terminal drought resistance. Plant Physiol. Biochem., 56, 24-34.

Rosenzweig C., Hillel D. (2015). Handbook of climate change and agroecosystems: The agricultural model intercomparison and improvement project (AgMIP) integrated crop and economic assessments. ICP Series on Climate Change Impacts, Adaptation, and Mitigation Vol. 3. Imperial College Press, doi:10.1142/p970.

Rossi M., Bitocchi E., Bellucci E. et al. (2009) Linkage disequilibrium and population structure in wild and domesticated populations of Phaseolus vulgaris L. Evol Appl., 2, 504-522

Saadi S., Todorovic M., Tanasijevic L., Pereira L.S., Pizzigalli, C., Lionello P. (2015). Climate change and Mediterranean agriculture: Impacts on winter wheat and tomato crop evapotranspiration, irrigation requirements and yield. Agric. Water Manag., 147, 103-115.

Sairam R.K., Tyagi A. (2004). Physiological and molecular biology of salinity stress tolerance in plants. Current Sci. 86, 407-

Salinas C.X., Mendieta J. (2013). Mitigation and adaptation investments for desertification and climate change: an assessment of the socioeconomic return. Mitig. Adapt. Strateg. Global Change 18, 659-672.

Sánchez E., Ruiz J.M., López-Lefebre L.R., Rivero R.M., García P.C., Romero L. (2001) Proline metabolism in response to highest nitrogen dosages in green bean plants (Phaseolus vulgaris L. cv Strike). J. Plant Physiol., 158, 593-598.

Saradhi P., Alia P., Arora S., Prasad K.V. (1995). Proline accumulates in plants exposed to UV radiation and protects them against UV induced peroxidation. Biochem. Biophys. Res. Commun., 209, 1-5.

Schauberger B., Archontoulis S., Arneth A., Balkovic J., Ciais P., Deryng D., et al. (2017). Consistent negative response of US crops to high temperatures in observations and crop models. Nat. Commun., 8, 13931.

Schiop S.T., Al Hassan M., Sestras A.F.,Boscaiu M., Sestras R.E., Vicente O. (2015) Identification of Salt Stress Biomarkers in Romanian Carpathian Populations of Picea abies (L.) Karst. PLOS ONE 10(8): e0135419. doi:10.1371/journal.pone.0135419.

Seemann J.R., Critchley C. (1985). Effects of salt stress on the growth, ion content, stomatal behaviour and photosynthetic capacity of a salt-sensitive species, Phaseolus vulgaris L. Planta, 164, 151-162.

Sen A., Ozturk I., Yaycili O., Alikamanoglu S. (2017). Drought tolerance in irradiated wheat studied by genetic and biochemical markers. J. Plant Growth Regul., 36, 669-676.

Serrano-Serrano M., Hernández-Torres J., Castillo-Villamizar G., Debouck D.G., Sanchez M. (2010). Gene pools in wild Lima vean (Phaseolus lunatus L.) from 
the Americas: evidences for an Andean origin and past migrations. Mol. Phylogenet. Evol., 54, 76-87.

Shabala S., Cuin T.A. (2007). Potassium transport and plant salt tolerance. Physiol. Plant., 133:651-669.

Shalaby T., Bayoumi Y., Alshaal T., Elhawat N., Sztrik A., El-Ramady H. (2017). Selenium fortification induces growth, antioxidant activity, yield and nutritional quality of lettuce in salt-affected soil using foliar and soil applications. Plant Soil, 421 (1-2), 245-258.

Shi J., Xue S.J., Kakuda Y., Ilic S., Kim D. (2007). Isolation and characterization of lectins from kidney beans (Phaseolus vulgaris). Process Biochem., 42(10), 1436-1442.

Shrivastava P, Kumar R (2015) Soil salinity: a serious environmental issue and plant growth promoting bacteria as one of the tools for its alleviation. Saudi J. Biol. Sci 22, 123-131

Sills G., Nienhuis J. (1993). Field plot technique affects snap bean yield evaluation. J. Am. Soc Hortic. Sci., 188, 672-674.

Singh S.P. (1989) Patterns of variation in cultivated common bean (Phaseolus vulgaris, Fabaceae). Econ. Bot. 43, 39-57.

Singh S.P., Gepts P., Debouck D.G. (1991) Races of common bean (Phaseolus vulgaris, Fabaceae). Econ. Bot. 45, 379-396.

Singh S.P., Hayes R., Robison C., Dennis M., Powers E. (2001) Response of bean (Phaseolus vulgaris L.) cultivars to drought stress. Annu Rpt Bean Improv Coop $44: 45-46$

Singh-Gill S., Tuteja N. (2010). Reactive oxygen species and antioxidant machinery in abiotic stress tolerance in crop plants. Plant Physiol Biochem 48(12):90930. doi: 10.1016/j.plaphy.2010.08.016.

Siripornadulsil S., Train S., Verma D.P.S., Sayre R.T. (2002). Molecular mechanisms of proline mediated tolerance to toxic heavy metals in transgenic microalgae. Plant Cell, 14, 2837-2847.

Slama I., Abdelly C., Bouchereau A., Flowers T., Savouré A. (2015). Diversity, distribution and roles of osmoprotective compounds accumulated in halophyte under abiotic stress. Ann. Bot., 11, 433-477.

Smirnoff N., Cumbes Q.J. (1989). Hydroxyl radical scavenging activity of compatible solutes. Phytochemistry, 28, 1057-1060.

Solano-Cervantes F., Diaz-Ruiz R., Jacinto-Hernández C., Huerta-de la Peña A. (2009). Agricultural practices, morphologic, proteinic and culinary description of the grain of bean cultivars sowed in the region of Tlatzala, Guerrero. $R a$ Ximhai 5 (2), 187-199.

Szabados L., Savouré A. (2010). Proline: A multifunctional amino acid. Trends Plant Sci., 15, 89-97. 
Taïbi K.., Taïbi F., Abderrahima L.A. Ennajah A. Belkhodja M., Mulet J.M. (2016). Effect of salt stress on growth, chlorophyll content, lipid peroxidation and antioxidant defence systems in Phaseolus vulgaris L. S. Afr. J. Bot., 105, 306312.

Tazuke A., Wada T., Kanazawa T. (2009). Effects of $\mathrm{NaCl}$ salinity on the sugar metabolism of common bean (Phaseolus vulgaris L.) cv. "Tsurunashi Marusaya Kurosando" fruit grown in solution culture. J. ISSAAS, 15, 32-43.

Terán H, Singh S.P. (2002) Comparison of sources and lines selected for drought resistance in common bean. Crop Sci. 42, 64-70.

Tesfaye K., Zaidi P., Gbegbelegbe S., Boeber C., Getaneh F., Seetharam K., et al. (2017). Climate change impacts and potential benefts of heat-tolerant maize in South Asia. Theor. Appl. Clim., 130, 959-970.

Tester M., Davenport R. (2003). $\mathrm{Na}^{+}$tolerance and $\mathrm{Na}^{+}$transport in higher plants. Ann. Bot. 91, 503-527.

Thuzar K., Zaw A., Hirasawa T., Ookawa T., Hirata Y. (2011). Genetic analysis of Myanmar Vigna species in responses to salt stress at the seedling stage. Afr. J. Biotechnol., 10(9), 1615-1624.

Türkan I., Demiral T. (2009). Recent developments in understanding salinity tolerance. Env. Exp. Bot. ;67, 2-9.

USDA. National Nutrient Database for Standard Reference Release 27: Basic Report 16032, Beans, Kidney, red, mature seeds, raw. 2015 [cited 2016 Sept 23, 03:45EDT]; Available from: http://ndb.nal.usda.gov/ndb/nutrients/index.

Vaid K., Gupta, V., Singh R. (1985). Stability analysis in dry bean. Crop Improv. 12, 28-31.

Van Breusegem F., Dat J.F. (2006). Reactive oxygen species in plant cell death. Plant Physiol. Biol.141, 384-390

Venuprasad R, Lafitte H.R., Atlin G.N. (2007). Response to Direct Selection for Grain Yield under Drought Stress in Rice. Crop Sci., 47(1), 285-293. $10.2135 /$ cropsci2006.03.0181

Verbruggen N., Hermans C. (2008). Proline accumulation in plants: A review. Amino Acids, 35, 753-759.

Verma S., Mishra S.N. (2005). Putrescine alleviation of growth in salt stressed Brassica juncea by inducing antioxidative defense system. J. Plant Physiol. 162, 669677.

Vermeulen S.J. Campbell B.M. (2012). Ingram, J.S. Climate change and food systems. Annu. Rev. Environ. Resour. 2012, 37, 195-222.

Vermeulen S.J., Aggarwal P.K., Ainslie A., Angelone C., Campbell B.M., Challinor A. J., et al. (2012). Options for support to agriculture and food security under climate change. Environ. Sci Pol., 15, 136-144. 
Vogel E., Meyer, R. (2018). Chapter 3 - Climate change, climate extremes, and global food production- Adaptation in the agricultural sector. In Z. Zommers \& K. Alverson (Eds.), Resilience (pp. 31-49). Elsevier.

Volkov V., Wang B., Dominy P.J., Fricke W., Amtmann A. (2003). Thellungiella halophila, a salt-tolerant relative of Arabidopsis thaliana, possesses effective mechanisms to discriminate between potassium and sodium. Plant Cell Environ., 27, 1-14.

Wang Q, Ang Q., Lin F., Wei S.H., Meng X.X., Yin Z.G., Guo Y.F. Yang G.D. (2019). Effects of drought stress on endogenous hormones and osmotic regulatory substances of common bean (Phaseolus vulgaris L.) at seedling stage. Appl. Ecol. Environ. Res., 17, 4447-4457.

Wang M., Zheng Q., Shen Q., Guo S. (2013). The critical role of potassium in plant stress response. Int. J. Mol. Sci., 14, 7370-7390.

Wang Z., Li J., Lai C., Wang R.Y., Chen, X., Lian, Y. (2018). Drying tendency dominating the global grain production area. Glob Food Sec., 16, 138-149.

Waters C., Zalasiewicz J., Summerhayes C., Barnosky A., Poirier C., Gałuszka, A., Wolfe, A. (2016). The Anthropocene is functionally and stratigraphically distinct from the Holocene. Science, 351(6269), 137-147.

White J.W., Castillo J.A., Ehleringer J.R., García-C. J.A,, Singh S.P. (1994) Relations of carbon isotope discrimination and other physiological traits to yield in common bean (Phaseolus vulgaris) under rainfed conditions. J. Agric. Sci. 122, 275-284.

Wilhite D.A. (2000). Drought: A Global Assessment. Vols. 1 and 2. Routledge, New York, Routledge, New York.

Wollenberg E., Richards M., Smith P., Havlík P., Obersteiner M., Tubiello F.N., Herold M., Gerber P., Carter S., Reisinger A., et al. (2016). Reducing emissions from agriculture to meet the $2{ }^{\circ} \mathrm{C}$ target. Glob. Chang. Biol., 22, 3859-3864.

Yin Y. G., Kobayashi Y., Sanuki A., Kondo S., Fukuda N., Ezura H., Sugaya S., Matsukura, C. (2010). Salinity induces carbohydrate accumulation and sugarregulated starch biosynthetic genes in tomato (Solanum lycopersicum L. cv. 'Micro-Tom') fruits in an ABA- and osmotic stress-independent manner. J. Exp. Bot. 61(2), 563-574. https://doi.org/10.1093/jxb/erp333.

Yoshida J., Tomooka N., Khaing T.Y., Sunil Shantha P.G., Naito H., Matsuda Y., Ehara H. (2020). Unique responses of three highly salt tolerant wild Vigna species against salt stress. Plant Prod. Sci., 23, 114-128.

Zalasiewicz J., Williams M., Haywood A., Ellis M. (2011). The Anthropocene: a new epoch of geological time? Philos. Trans. Royal Soc. A 369, 835-841.

Zengin F.K., Munzuroglu O. (2005). Effects of some heavy metals on content of chlorophyll, proline and some antioxidant chemicals in bean (Phaseolus vulgaris L.) seedlings. Acta Biol. Cracov. Bot., 47, 157-164. 
Zhao, J., Yang, X., Dai, S., Lv, S., Wang, J. (2015). Increased utilization of lengthening growing season and warming temperatures by adjusting sowing dates and cultivar selection for spring maize in Northeast China. Eur. J. Agron., 67, 1219.

Zhou R., Yu X., Ottosen C.O., Rosenqvist E., Zhao L., Wang Y., Yu W., Zhao T.J. Wu, Z. (2017). Drought stress had a predominant effect over heat stress on three tomato cultivars subjected to combined stress. BMC Plant Biol. 17- 24.

Ziska L., Knowlton K., Rogers C., Dalan D., Tierney N., Mary Ann Elder, Filley W., Shropshire J., Ford L., Hedberg C., Fleetwood P., Hovanky K., Kavanaugh T., Fulford G., Vrtis R., Patz J. Portnoy J., Coates F., Bielory L., Frenz D. (2011). Recent warming by latitude associated with increased length of ragweed pollen season in central North America. Proc. Natl. Acad. Sci. USA, 108 (10), 4248-4251; https://doi.org/10.1073/pnas.1014107108

Zörb C., Geilfus C.M., Dietz K. (2018). Salinity and crop yeild. Plant Biol., 21, 31-38. 